\title{
ILLUSTRATING SWING VOTES II: UNITED STATES SUPREME COURT
}

\author{
NichOlas L. GEORGAKOPOULOS AND FRANK SUlLIVAN, JR.*
}

\section{INTRODUCTION}

Can we see how different the 5-4 majorities of the United States Supreme Court are? What is the number of swing votes connecting them and their relative importance?

In a previous article in this journal, we developed a method for displaying the swing votes of a supreme court, the (tight) majorities they connect, and the opinions those majorities issue. ${ }^{1}$

We apply our method to compositions of the United States Supreme Court after 1946 that have over 50 tightly split opinions: the compositions of the court defined by its junior justice being Vinson, Stewart, Powell, Stevens, O'Connor, Kennedy, Breyer, Alito, and Kagan.

This look at 5-4 coalitions and swing votes primarily reveals an ebb and flow of a tide of a judicial practice we call fluidity, which corresponds to the flexibility or variability with which justices of a supreme court form tight coalitions. The graphs allow us to observe the number of coalitions, their opinions, and swing votes. Fluidity reaches its high point during the composition defined by Stevens as the junior justice, i.e. from 1975 to 1981. Its adjacent compositions, Powell's (1972-75) and O'Connor's (1981-86), are similar. However, the recent compositions, defined by the junior justices being Alito (2006-09) and Kagan (2010-16), differ. Those appear similar to the early ones, defined by Vinson (1946-49) and Stewart (1958-62). Whereas we focus on the graphical representation of 5-4 coalitions and swing votes, several additional phenomena follow the same pattern.

The graphs of the compositions that exhibit high fluidity are different in having more coalitions (9 to 11), linked by more swing votes (in the teens), with those coalitions being closer to proportional in the number of opinions that they issue. The graphs of the coalitions with low fluidity display few coalitions ( 3 or 4 ), few swing votes ( 2 or 3 ), and even fewer, usually two, coalitions doing the lion's share of issuing opinions. Additionally, the index of fluidity follows that pattern, reaching 0.57 for the most fluid composition of Stevens but being around

* Nicholas Georgakopoulos is the Harold R. Woodard Professor of Law, Indiana University Robert H. McKinney School of Law, Indianapolis. Frank Sullivan, Jr. is the Indiana University Bicentennial Professor at the same institution and was an Associate Justice of the Indiana Supreme Court from 1993 until 2012. We wish to thank Jim Chen, Kent Greenfield, Shi-Ling Hsu, Jonathan Nash, Richard Posner as well as participants in the 2016 Midwestern Law and Economics annual meeting and the 2016 Constitution Day conference at McKinney Law School for their comments and acknowledge the excellent research assistance of Allan Griffey, Henry Robison, and John Millikan.

1. Nicholas Georgakopoulos \& Frank Sullivan, Jr., Illustrating Swing Votes I: Indiana Supreme Court, 53 IND. L. REV. 95 (2020). 
0.30 for the least fluid ones. ${ }^{2}$ The issuance of opinions with a political slant opposite to the majority of opinions of that coalition, what we call contraslanted opinions, again has a high during the fluid compositions (from 2.5 percent to 5 percent compared to 0 percent to 2 percent in the less fluid ones). We speculate about the causes of this phenomenon: how it might relate to the composition of the court by the justices' appointing party but fails to do so.

Secondarily, this analysis reveals the limitations of attempts to fit supreme court adjudication in locational models, especially the median voter theorem. The strongest discrepancies with the median voter theorem are that (1) often the most active swing vote is not the justice who according to the ideological rankings is the median; (2) justices far from the median can be the second most active swing vote; and (3) the busiest swing vote changes without a change of the median justice. Moreover, even a multi-dimensional locational model cannot remain accurate because adjudication makes new factors become important, what from the perspective of locational models would correspond to the creation of new dimensions. We offer the Apprendi line of cases and the uniqueness of its coalition as an example of a creation of a new dimension that could not have been anticipated. ${ }^{3}$

For the related literature, we refer to our prior article.

Our approach stands in contrast to attempts to identify a single justice as the swing vote to the extent that we reveal all the swing votes of each court. ${ }^{4}$ Notably, our approach reveals Scalia and Thomas to be significant swing votes despite not being in the ideological middle of the court.

\section{THE DATA}

We use the vote-centered database of the SupremeCourtDatabase.org to identify all 5-4 opinions and ignore opinions where less than nine justices voted. ${ }^{5}$ The version of the database that we used covers the years 1946 to 2016. The database codes each vote on each issue in each opinion. ${ }^{6}$ We ignore the issues that

2. Frank Sullivan, Jr., Nicholas L. Georgakopoulos, \& Dimitri Georgakopoulos, The Fluidity of Judicial Coalitions: A Surprising Look at Coalitions within the Supreme Courts of the United States and Indiana, JUDiCATURE, Autumn 2016, at 34, 36 (developing the index of fluidity).

3. See text accompanying notes 22-23 and Appendix A, text accompanying notes 27-37.

4. The two illustrations of ideological positions of justices that stand out are from Martin \& Quinn and Bailey, with additional such graphics in other publications by Bailey. See Andrew D. Martin \& Kevin M. Quinn, Dynamic Ideal Point Estimation via Markov Chain Monte Carlo for the U.S. Supreme Court, 1953-1999, 10 PoL. ANAL. 134 (2002); Michael A. Bailey, Measuring Court Preferences, 1950-2011: Agendas, Polarity and Heterogeneity (Working Paper, August 2012). See also Wikipedia, Ideological Leanings of U.S. Supreme Court Justices (as of Sept. 28, 2017) [https://perma.cc/7LCZ-K6HM] [hereinafter Ideological Leanings].

5. The Supreme Court Database, WASH. U. L. (Sept. 13, 2019), supremecourtdatabase.org/ data.php [https://perma.cc/ZN48-4BWN].

6. Id. The supremecourtdatabase.org codes the votes of each justice on each issue of each dispute with a value from 1 to 8 . A value of 1 means the justice voted with the majority, 2 that the 
produced other than 5-4 splits. Thus, we produce a single record for each opinion. We make the resulting data available online at https://mckinneylaw.iu.edu/ilr/pdf/vol53p135.pdf and produce tables of the opinions and their summaries in Appendix B. The database codes each outcome as liberal or conservative. We verify the database's coding and rarely disagree with it.

\section{THE GRAPHS}

We illustrate the swing votes for the court's compositions from 1946 to 2016 that produced more than fifty tightly split opinions. Those turn out to be its compositions defined by the junior justice being Vinson, Stewart, Powell, ${ }^{7}$ Stevens, O'Connor, Kennedy, Breyer, Alito, and Kagan. Figures 1 through 9 are the results. Because the data of the United States Supreme Court do not allow as deterministic a construction as did the Indiana data in our previous article, our arrangement of the majorities is not fully objective.

justice dissented, 3 that the justice concurred, 4 indicates a special concurrence, 5 indicates the judgement of the court, 6 indicates dissent from a denial of certiorari or dissent from summary affirmation of an appeal, 7 indicates a jurisdictional dissent and 8 indicates an equally divided vote. We treat values of 1, 3, 4, and 5 as votes for the majority and values of 2, 6, and 7 as dissenting votes. We only count opinions, not disputes; i.e., when a single opinion adjudicates more disputes, we only count it once.

7. Whereas Rehnquist was appointed on the same day as Powell and is listed as the junior justice by the Supreme Court, we name this composition of the court after Powell to avoid confusion with popular usage of the phrase "Rehnquist court" to refer to the period of Rehnquist as the Chief Justice, which comprises several different compositions of the court. 


\begin{tabular}{|c|c|c|c|c|c|}
\hline Jr. Justice & Date Appointed & $\begin{array}{c}\text { No of } \\
5-4 \text { Ops. }\end{array}$ & $\begin{array}{l}\text { Earliest } \\
\text { 5-4 op. }\end{array}$ & $\begin{array}{l}\text { Latest } \\
5-4 \text { op. }\end{array}$ & $\begin{array}{c}\text { Nominating } \\
\text { President (Party) }\end{array}$ \\
\hline Vinson & $6 / 24 / 1946$ & 83 & $11 / 1946$ & $6 / 1949$ & Truman (D) \\
\hline $\begin{array}{l}\text { Clark \& } \\
\text { Minton }\end{array}$ & $\begin{array}{r}8 / 24 / 1949 \\
10 / 12 / 1949 \\
\end{array}$ & 34 & $6 / 1950$ & $5 / 1953$ & Truman (D) \\
\hline Warren & $10 / 05 / 1953$ & 9 & $11 / 1953$ & $4 / 1954$ & Eisenhower (R) \\
\hline Harlan & $3 / 28 / 1955$ & 18 & $6 / 1955$ & $10 / 1956$ & Eisenhower (R) \\
\hline Brennan & $10 / 15 / 1956$ & 6 & $12 / 1956$ & $2 / 1957$ & Eisenhower (R) \\
\hline Whittaker & $3 / 25 / 1957$ & 39 & $4 / 1957$ & $6 / 1958$ & Eisenhower (R) \\
\hline Stewart & $10 / 14 / 1958$ & 84 & $12 / 1958$ & $4 / 1962$ & Eisenhower (R) \\
\hline $\begin{array}{l}\text { White \& } \\
\text { Goldberg }\end{array}$ & $\begin{array}{l}4 / 16 / 1962 \\
10 / 1 / 1962\end{array}$ & 41 & $11 / 1962$ & $6 / 1965$ & Kennedy (D) \\
\hline Fortas & $10 / 4 / 1965$ & 41 & $12 / 1965$ & $6 / 1967$ & Johnson (D) \\
\hline Marshall & $10 / 2 / 1967$ & 12 & $6 / 1968$ & $6 / 1969$ & Johnson (D) \\
\hline Burger & $6 / 23 / 1969$ & 4 & $12 / 1969$ & $12 / 1969$ & Nixon (R) \\
\hline Blackmun & $6 / 9 / 1970$ & 31 & $12 / 1970$ & $6 / 1971$ & Nixon (R) \\
\hline $\begin{array}{l}\text { Rehnquist } \\
\text { \& Powell }\end{array}$ & $\begin{array}{c}\text { 1/7/1972 } \\
\text { (both) }\end{array}$ & 100 & $2 / 1972$ & $6 / 1975$ & Nixon (R) \\
\hline Stevens & $12 / 19 / 1975$ & 128 & $4 / 1976$ & $6 / 1981$ & Ford (R) \\
\hline O'Connor & $9 / 25 / 1981$ & 148 & $12 / 1981$ & $7 / 1986$ & Reagan (R) \\
\hline Scalia & $9 / 26 / 1986$ & 42 & $11 / 1986$ & $6 / 1987$ & Reagan (R) \\
\hline Kennedy & $2 / 18 / 1988$ & 89 & $4 / 1988$ & $6 / 1990$ & Reagan (R) \\
\hline Souter & $10 / 9 / 1990$ & 22 & $1 / 1991$ & $6 / 1991$ & Bush I (R) \\
\hline Thomas & $10 / 23 / 1991$ & 31 & $4 / 1992$ & $6 / 1993$ & Bush I (R) \\
\hline Ginsburg & $8 / 10 / 1993$ & 13 & $12 / 1993$ & $6 / 1994$ & Clinton (D) \\
\hline Breyer & $8 / 03 / 1994$ & 191 & $11 / 1994$ & $6 / 2005$ & Clinton (D) \\
\hline Roberts & $9 / 29 / 2005$ & 2 & $1 / 2006$ & $1 / 2006$ & Bush II (R) \\
\hline Alito & $1 / 31 / 2006$ & 67 & $5 / 2006$ & 9/2009 & Bush II (R) \\
\hline Sotomayor & $8 / 8 / 2009$ & 17 & $1 / 2010$ & $6 / 2010$ & Obama (D) \\
\hline Kagan & $8 / 7 / 2010$ & 78 & $3 / 2011$ & $6 / 2015$ & Obama (D) \\
\hline
\end{tabular}

Table 1. Appointment and duration data for compositions as defined by junior justices. ${ }^{8}$

Short tenures (of compositions that do not produce enough tightly split opinions for a meaningful graph) separate most compositions. However, the

8. When the table identifies two justices as the junior justices, they either are appointed on the same day, as are Rehnquist and Powell, or no 5-4 opinions appear under the first appointed justice's composition, as is the case with Clark and White. 
compositions of Powell, Stevens, and O'Connor are in an uninterrupted sequence. This becomes clearer in Table 1.

Table 1 lists new justices by order of appointment over the period we study, 1946-2016. Each appointed justice, as the junior justice, defines a new composition of the court. The table has the date of appointment; the number of tightly split opinions; the dates of the earliest and the latest split opinions; and the nominating President and his party. In boldface are the rows of the justices who define compositions that issue enough, namely fifty, tightly split opinions for a graph.

We display each opinion as a curved triangle, like a very thin pizza slice, springing from the specific point that corresponds to its majority or, to restate, as a thick radius of a circle with its center at that majority. The result of several such triangles springing from a single majority is an angle defining a fraction of a circle with short lines separating the opinions of that majority. We set the largest such fraction of a circle to be slightly ( 5 percent) less than a semicircle in each figure. The result is that the size of the slice that corresponds to an opinion in each figure varies, depending on how many opinions the most prolific majority authored. For example, the slice corresponding to each opinion is much smaller in the Breyer court, where the most prolific majority issued eighty-six opinions, ${ }^{9}$ compared to the Stevens court, where the most prolific majority issued 19 opinions..$^{10}$ The legend of each figure has the total number of 5-4 opinions being illustrated and the output of the most prolific majority. Appendix B lists the 5-4 opinions by majority, but again, only majorities authoring more than two opinions.

We also display the slice corresponding to each opinion as either in hexagonal shading or dark grey (blue or red in the online version), depending on whether its political slant is liberal or conservative. Our coding mostly agrees with that of SupremeCourtDatabase.org. The few disagreements are due to placing emphasis on different levels of the outcome. We usually focus on the outcome that is most material to the parties, but that may differ from the nature of the outcome on a more abstract level. For example, a liberal outcome for the parties, such as the upholding of a local tax, may be the result of a conservative policy of a more abstract level, such as the principle of delegating more powers to state and local authorities. Appendix B, which lists the opinions, their summaries, and their political slant, indicates when we disagreed with the database's coding.

The figures let us see the consistent members of the conservative and the liberal coalitions, the swing votes, and which of the swing votes are dominant in the sense of connecting majorities that issue a disproportionately great number of opinions. Also interesting is the changing number of coalitions into which the court splits. We discuss each court composition in turn. An interactive unified graphic with popups of the opinions and their summaries is available on the

9. See infra Figure 7.

10. See infra Figure 4. 
web. ${ }^{11}$

\section{A. The Vinson Composition (1946-49)}

The first composition, defined by the appointment of Chief Justice Vinson as the junior justice on June 24, 1946, by Democratic President Truman, consists entirely of justices appointed by Democratic presidents, two by President Truman (the other Truman appointee was Burton, a Republican) and all of the others by President F.D. Roosevelt. However, tightly split decisions still arise. The conservative side has as its core Vinson with Burton and Reed. The liberal side has as its core Black, Douglas, and Murphy.

The graph has three coalitions issuing 100 percent liberal opinions: at the eight o'clock, nine o'clock, and ten o'clock positions. By the short lines along the outside of each arc separating the opinions, we see those issue, respectively, three, seven, and four opinions. On the conservative side, the graph displays two active coalitions, at two o'clock issuing three opinions and at three o'clock issuing thirty-three opinions. The number of opinions of the most prolific coalition drives the size of the arc that corresponds to each opinion. The most prolific coalition turns out to always be a conservative one and is usually at three o'clock. Its output is set to be 5 percent less than a semicircle. The unoccupied dots in the circle correspond to majorities that never formed or only formed to issue one or two opinions, which we do not display. The total number of points in the circle, 126, corresponds to the number of five-member majorities that are possible in a nine-member court. The lines connecting the majorities, akin to diagonals of the circle of dots, are the swing votes. Only one vote changes when two majorities are connected by a line. The line bears the name of the swing vote. The main swing vote is the one departing the most prolific coalition to form the most prolific one connected to that one, which is usually the second most prolific coalition overall (but not in the Powell and Stevens graphs, where that distinction goes to a second conservative coalition). Here the main swing vote is Frankfurter.

Compared to the compositions defined by Powell and later, the proportion of majorities that do not appear on the graph is high for the Vinson composition (as it is for the next composition, defined by Stewart). The swing vote away from the main conservative majority that produces the majority that authors the greatest number of liberal opinions is that of Frankfurter. Despite that Frankfurter is the most active swing vote, the ideological ranking of the justices does not place Frankfurter as the median justice (except for in the last term of the Vinson composition). Rather, from the perspective of ideology the median justice is Reed. According to the ideological ranking, Frankfurter begins Vinson's term as the second most conservative member of the court and swings significantly toward a more liberal rating to switch to the liberal side; he passes from the

11. The graphic of all compositions with popups of the opinions and parenthetical descriptions is at https://mckinneylaw.iu.edu/instructors/Georgakopoulos/Prof/VisgSCtSwings-Pop Up/VisgSCtSwings-CombinedPopupOnly.html [https://perma.cc/JT2X-SDX3]. It is also accessible from nicholasgeorgakopoulos.org, under "Scholarship" and the entry corresponding to this article. 
median position during the last term of the Vinson composition. Upon the appointment of Clark and Minton, Frankfurter becomes the seventh most conservative justice, i.e., the third most liberal, after Douglas and Black (albeit with a difference).

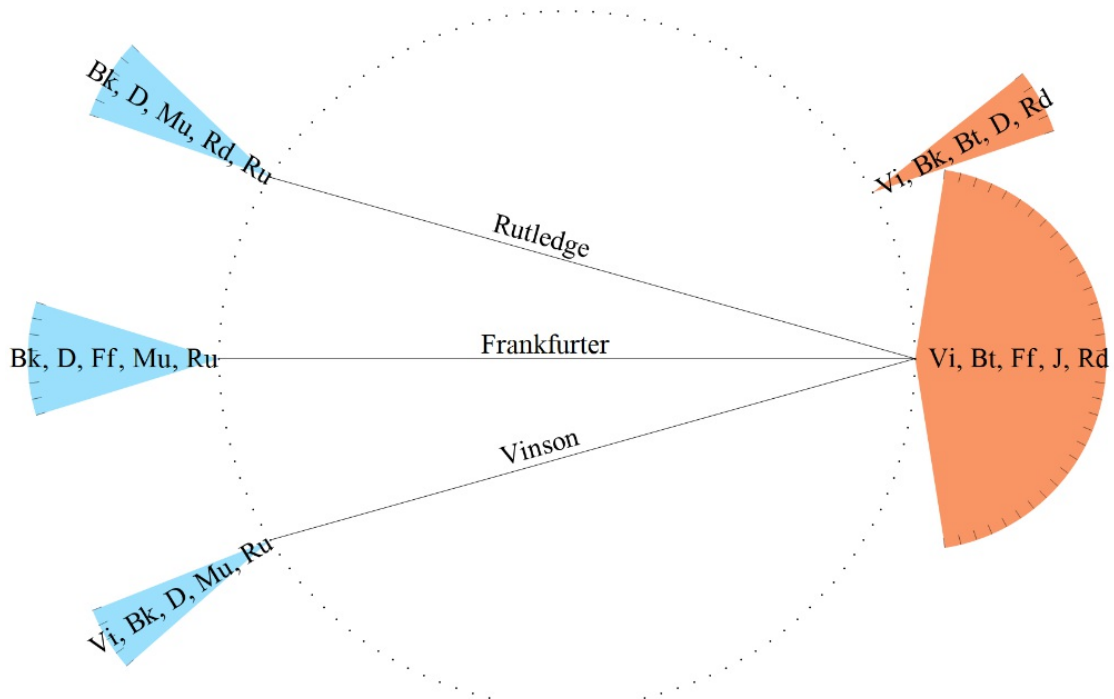

Figure 1. The swing votes of the 5-4 majorities of the Vinson composition of C.J. Vinson (Vi) and Black (Bk), Burton (Bt), Douglas (D), Frankfurter (Ff), Jackson (J), Murphy (Mu), Reed (Rd), and Rutledge (Ru), all Democratic appointees, as they result from fifty-three opinions dating from November 18, 1946, to June 27, 1949 , that were issued by majorities issuing more than two opinions and where the most prolific majority authors thirty-three opinions (62 percent of the opinions appearing in the graph).

The second swing vote is that of Rutledge, to a majority that authors five opinions. According to the ideological rankings, Rutledge begins the Vinson composition as the sixth most conservative justice (the fourth most liberal after Black, Murphy, and Douglas) and over its three terms swings to become its most liberal member. The importance of Rutledge's swing vote given how far the ideological rankings place him from the median is particularly interesting. An analogous phenomenon appears during the Alito and Kagan compositions, where the justice rated as second most conservative (Scalia) and the one rated as the most conservative (Thomas) are, respectively, the second most active swing votes. A single-dimensional approach based on the median voter and the ideological ranking of the justices cannot explain how a justice who is not near the median can have an impactful role as a swing vote.

The main (conservative) coalition also experiences the swing vote of Vinson, to form a majority that authors four opinions. Vinson's ideological ranking places him near the median. Therefore, the importance of Vinson's swing vote is not surprising from the perspective of an approach that rests on the median voter. 


\section{B. The Stewart Composition (1958-62)}

Several judicial departures and appointments separate the Vinson from the Stewart composition, the next composition that issues enough 5-4 opinions for a meaningful graph. The justices in the Vinson composition who left the court prior to Stewart's appointment are Burton, Jackson, Murphy, Reed, Rutledge, and Vinson. The continuing justices are Black, Douglas, and Frankfurter. The new justices are Brennan, Clark, Harlan, Stewart, Warren, and Whittaker. Clark was appointed by Democratic President Truman. All other new justices are Republican President Eisenhower's appointees, giving the court a Republicanappointed majority, a feature that remains in all subsequent compositions that we study. The Stewart court, however, is also tightly split by appointment, with just five of its members being Republican appointees. This phenomenon will only reappear during the Kagan composition, the last one we study.

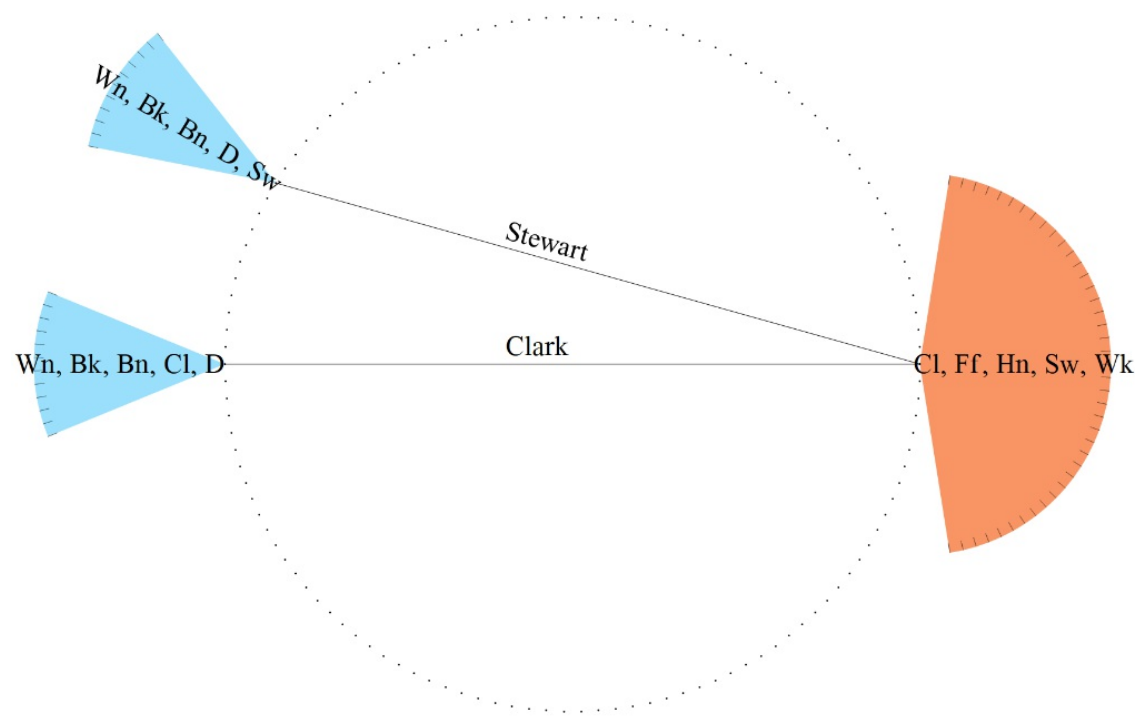

Figure 2. The swing votes of the 5-4 majorities of the Stewart composition of C.J. Warren (Wn) and Black (Bk), Brennan (Bn), Clark (Cl), Douglas (D), Frankfurter (Ff), Harlan (Hn), Stewart (Sw), and Whittaker (Wk) - five Republican appointees, four Democratic — as they result from sixty-one opinions dating from December 8, 1958, to April 19,1962, that were issued by majorities issuing more than two opinions and where the most prolific majority authors forty opinions (66 percent of the opinions appearing in the graph).

The Stewart composition also presents an interesting and unique problem in the categorization of its fifteen opinions related to "un-American" committee activity. ${ }^{12}$ The court splits 5-4 conservative, with Black, Brennan, Douglas, and

12. The Stewart composition issues several opinions related to individuals targeted as communist sympathizers or accused of membership in the Communist Party and who had refused 
Warren in the dissent. Of those, only Black and Douglas were Democratic appointees. This tight split, therefore, does not correspond to a difference between appointing parties, with the caveat that Brennan, an appointee of Republican President Eisenhower, was a Democrat. The solitary liberal opinion on this matter reveals Stewart as the swing vote but in a curious manner. ${ }^{13}$

The ideological rankings of justices place Black and Douglas as the by far most liberal members of this court and identify the median justices as Frankfurter, Stewart, and Brennan (as does Bailey) or Clark and Stewart (as do Martin and Quinn). The focus on 5-4 majorities reveals Clark as the most frequent swing vote, closely followed by Stewart, without Frankfurter or Brennan appearing as active swing votes.

The Stewart composition also reveals a polarization that is greater even than the next most intense ones, those of the compositions defined by Alito and Kagan more than forty years later. The figure of the 5-4 majorities and their swing votes has only three majorities, because only three majorities issue more than two opinions. The corresponding figures for the Alito and Kagan compositions have four majorities. All other compositions produce a graph with more majorities - significantly more in the cases of the compositions defined by Stevens, and O'Connor, where the majorities number eleven and twelve,

to cooperate with committees akin to the House Un-American Activities Committee. The targeted individuals objected on various grounds, mostly the right against self-incrimination and the rights of free association. The United States Supreme Court's 5-4 opinions of this composition never vindicated the corresponding rights despite that the dissenters were quite vocal. However one reacts to this chapter of history and Constitutional interpretation, it presents a categorization problem. Clearly, these opinions should not be categorized separately according to the resulting legal subject matter, so as to scatter them in subject matters such as criminal procedure, administrative law, and professional responsibility. Rather, these opinions belong in a single group. We place these opinions in the broader category of opinions related to social impact. In subsequent compositions of the Court, this category will have opinions about desegregation, abortion, and gay rights. In the earlier composition of Vinson we only place in this category one opinion about conscientious objectors.

13. See Deutch v. United States, 367 U.S. 421 (1961). In the Deutch opinion, Stewart joins the dissenters to form a majority to reverse an individual's conviction for refusing to identify other communists on the grounds that the questions were not pertinent to the committee's charge. The greater ideals of civil rights do not reach the surface. Nor can one argue that the Deutch opinion corresponds to a change in Stewart's position. Although the opinion, appearing in 1961, comes late in this composition, opinions of the opposite slant appear before and after it. Rather than corresponding to a change in the details of the underlying civil rights, the difference appears to stem from the human details of the way this committee conducted its prosecution, such as calling the same witness for the second time, forcing his appearance in the Southern Summer, and interrupting the witness's vacation. Rather than Stewart taking the position that the committee overreached substantively, it seems more plausible that his swing vote is due to an overreach that may be called procedural. As a result, the swing of Stewart's vote does not fit in a model of the underlying rights but in a model of the procedures that a governmental entity may use to exercise its advantage. 
respectively.

\section{The Powell Composition (1972-75)}

The composition defined by the unusual appointment on the same day of Rehnquist and Powell ("Powell composition"14) is also removed from the prior one, of Stewart, by several appointments. The continuing justices are Brennan, Douglas, and Stewart.

In the Powell composition, Burger, Blackmun, and Rehnquist are in all the conservative coalitions. On the other side, Brennan, Douglas, and Marshall are in all the liberal coalitions. The swing vote away from the main conservative majority that produces the majority that author the greatest number of liberal opinions is that of White, an appointee of Democratic President Kennedy. This main liberal coalition, at the nine o'clock position, authors ten opinions. It includes White and Stewart, a Republican appointee. Stewart is also a swing vote, producing the second most productive conservative coalition, at the four o'clock position, which authors sixteen opinions.

14. Again, we name this composition after Powell despite that Rehnquist is considered the junior of the two to avoid confusion from the colloquial use of "Rehnquist court" to refer to the years that the court had Rehnquist as its Chief Justice. 


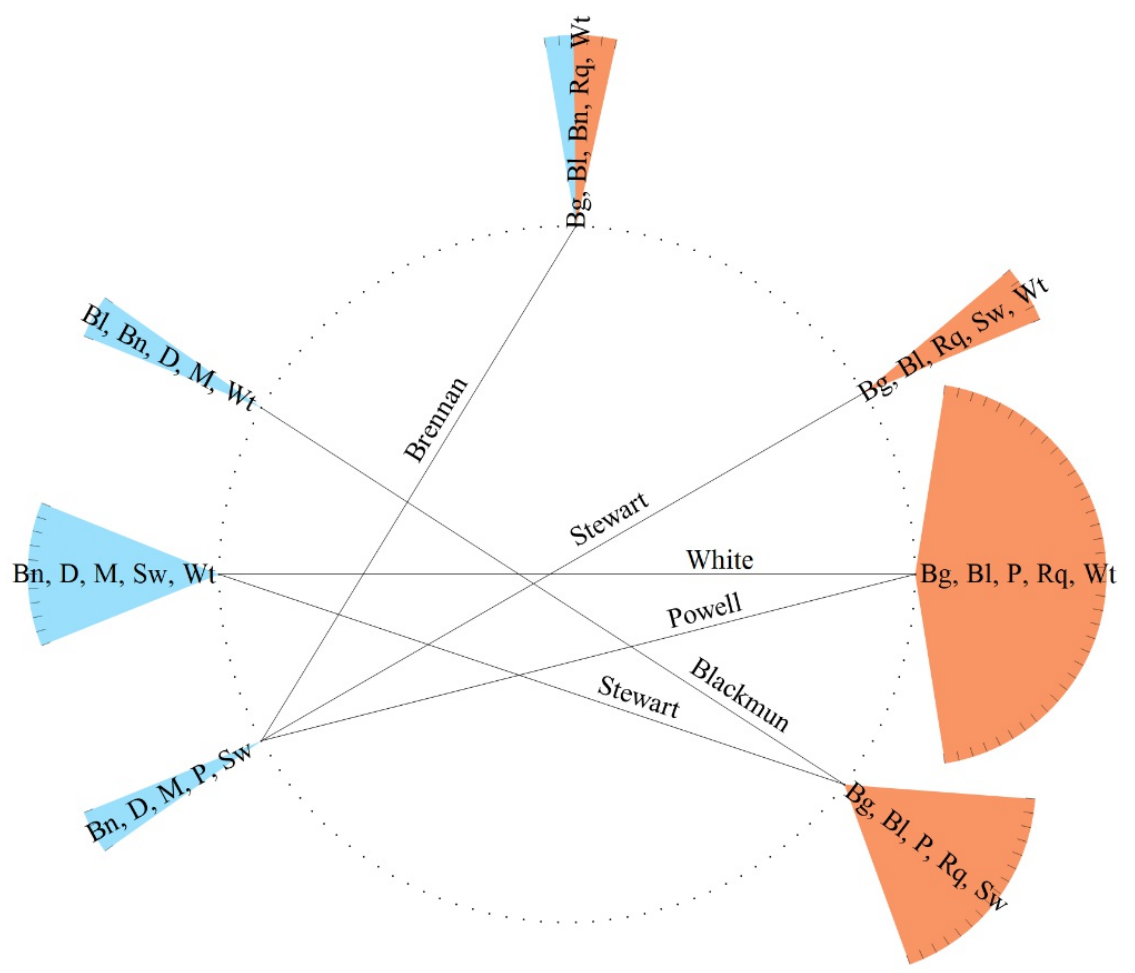

Figure 3. The swing votes of the 5-4 majorities of the Powell composition of C.J. Burger (Bg), and Blackmun (Bl), Brennan (Bn), Douglas (D), Marshall (M), Powell (P), Rehnquist (Rq), Stewart (Sw), and White (Wt) - six Republican appointees and three Democratic - as they result from seventy-seven opinions dating from March 22, 1972, to June 30, 1975, that were issued by majorities issuing more than two opinions and where the most prolific majority authors thirty-seven opinions (48 percent of the opinions appearing in the graph).

Worth noting is that Brennan, despite voting with the liberal block, was appointed by the Republican President Eisenhower. The Democratic appointees are Douglas (of Roosevelt), White (of Kennedy), and Marshall (of Johnson).

The analyses of ideological leaning place White as the median justice and Stewart to his immediate left in this composition. ${ }^{15}$ This is a composition where the median justice, according to the ideological rankings, is also the main swing vote; the next most active swing votes, Powell and Stewart, are also near the ideological median, making this a composition that is not far from the expectations of a median voter vision.

15. See supra note 3. 


\section{The Stevens Composition (1975-81)}

The Stevens composition is the result of the appointment of Stevens by Republican President Ford to replace Douglas. The majorities are much more fluid, leaving smaller liberal and conservative cores. The conservative core is down to Burger and Rehnquist. The liberal core is down to Brennan and Marshall.

Strikingly, unlike all other compositions of the United States Supreme Court that we study, the Stevens court reveals no dominant conservative or liberal coalitions and, therefore, no dominant swing votes. Powell, who prior to the Stevens composition, was consistently in the conservative coalitions, is now often a swing vote. The likely explanation is that the new composition of the court produces divisions in a more conservative way, so that Powell finds himself more often at the center of the court. The replacement of the very leftmost member of the court, Douglas, by a centrist conservative, Stevens, did not change the median justice, because Stevens was more liberal than the median (and indeed appears in four of the coalitions that issue only liberal opinions but in only one conservative). Therefore, White's loss of the role of the main swing vote refutes the median voter theorem.

Indeed, the ideological scorings of the justices continue to place White as the median justice between Blackmun to his left and Powell to his right, except for the last segment of this composition, when the ideological scorings move White to Powell's right. Whereas White does appear as an active swing vote, his vote does not swing away from the busiest coalition. Powell's is the most active swing vote. 


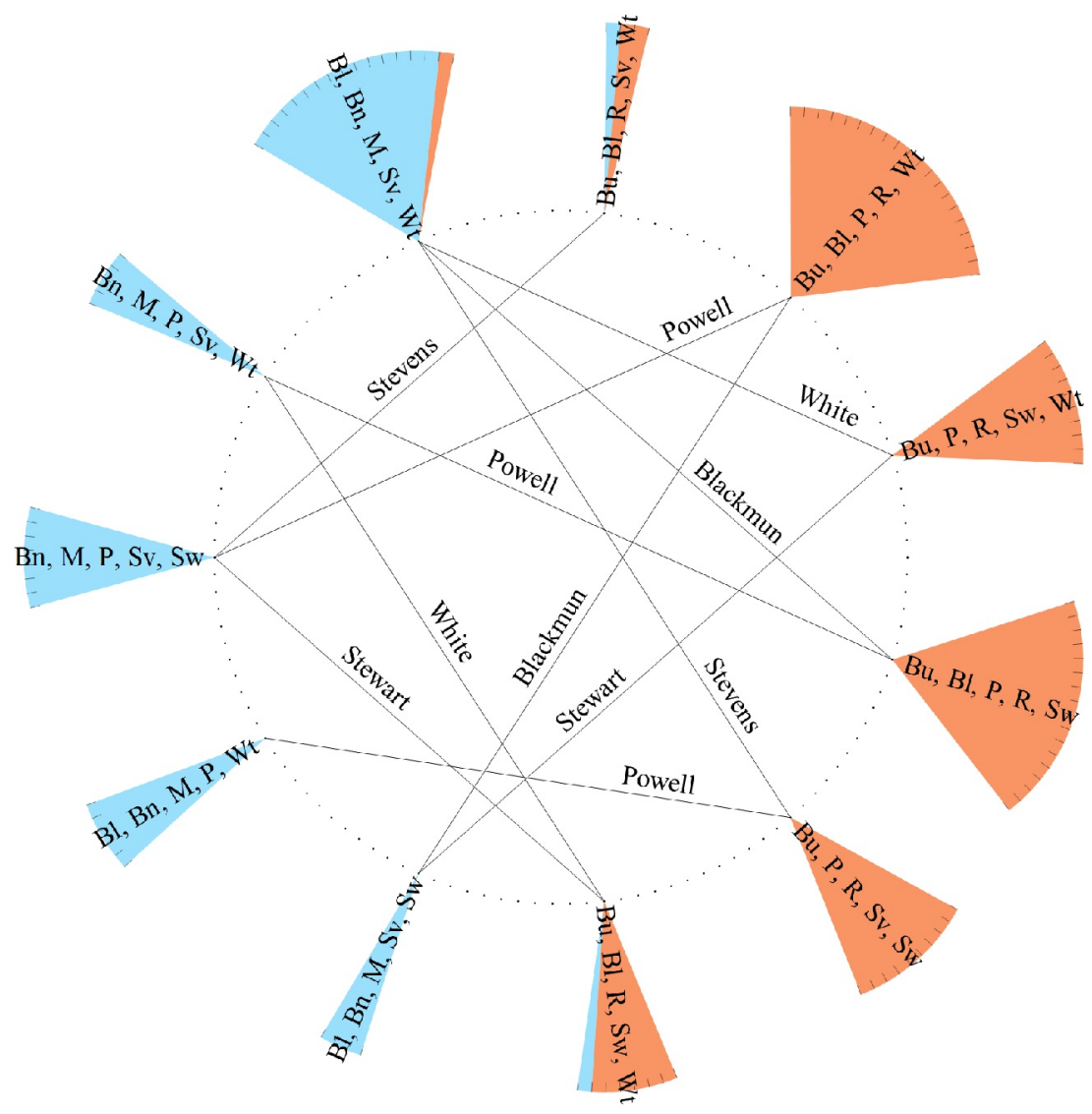

Figure 4. The swing votes of the 5-4 majorities of the Stevens composition of C.J. Burger (Bg) and Blackmun (Bl), Brennan (Bn), Marshall (M), Powell (P), Rehnquist (Rq), Stevens (Sv), Stewart (Stewart), and White (Wt) - seven Republican appointees and two Democratic - as they result from ninety-eight opinions dating from April 26, 1976, to June 26, 1981, that were issued by majorities issuing more than two opinions and where the most prolific majority authors nineteen opinions (19 percent of the opinions appearing in the graph).

The Stevens composition, therefore, is in tension with the median voter theorem in two ways: in the change of its swing vote from the prior composition despite the lack of change of the median justice, and in the fact that its median justice, White, is not the busiest swing vote.

\section{E. The O'Connor Composition (1981-86)}

The O'Connor composition is the result of the appointment of O'Connor by Republican President Reagan to replace Stewart. The conservative core remains Burger and Rehnquist. The liberal core remains Brennan and Marshall. 
The most prolific coalition is the conservative one at three o'clock, which issues forty-six opinions. The main swing vote of White produces the most productive liberal coalition, at the nine o'clock position, which authors twenty opinions. The second swing vote, that of Powell, produces the liberal majority coalition at the ten o'clock position, which authors sixteen opinions. One more notable swing vote is that of Stevens from the main liberal coalition to form the second most active conservative coalition at the four o'clock position, which authors ten opinions.

The ideological ranking of the justices places White and then Powell as the median justices of the O'Connor composition. That they are also its main swing votes agrees with the expectations of the median voter theorem.

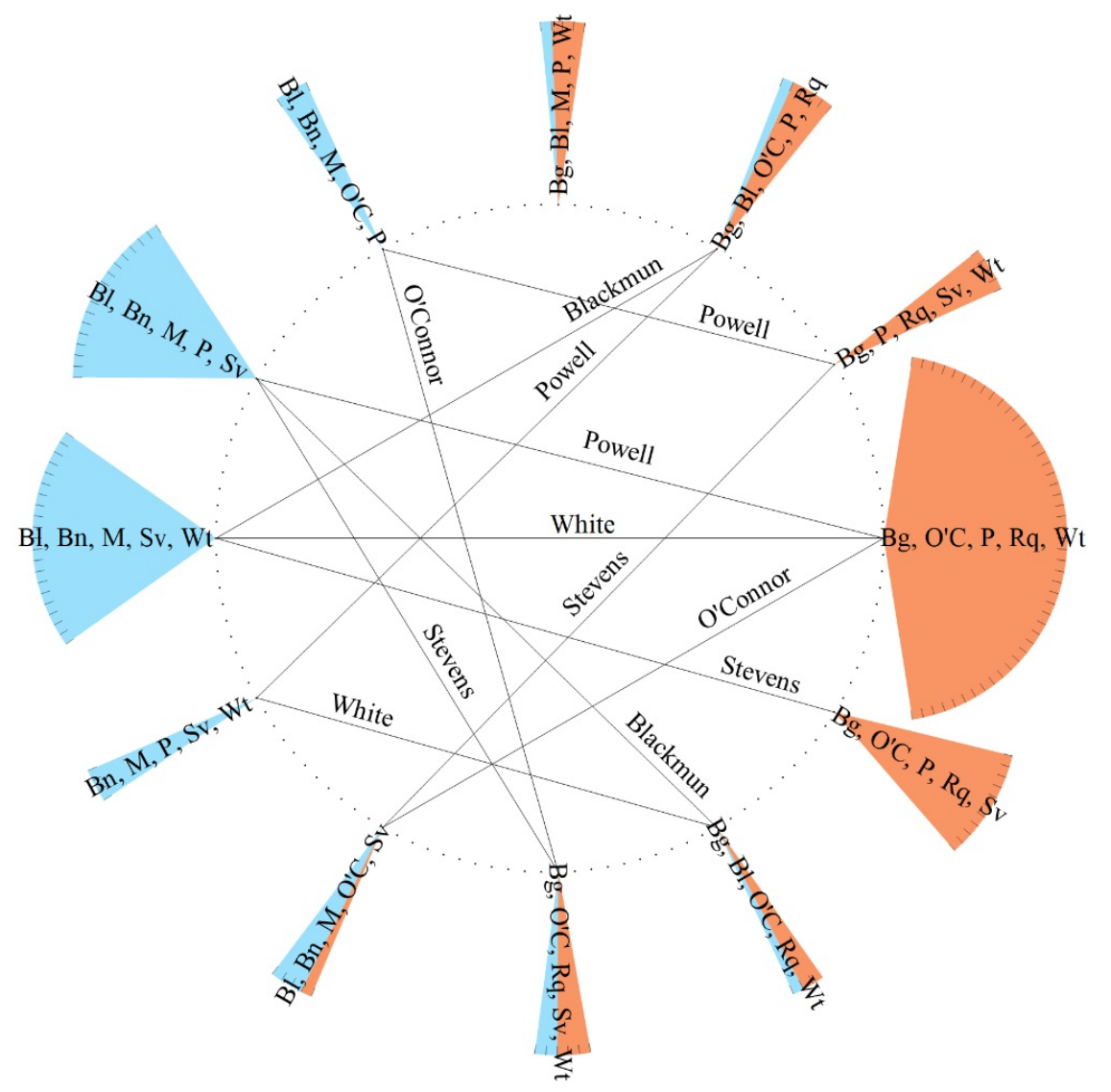

Figure 5. The swing votes of the 5-4 majorities of the O'Connor composition of C.J. Burger (Bg), and Blackmun (Bl), Brennan (Bn), Marshall (M), O’Connor (O’C), Powell (P), Rehnquist (Rq), Stevens (Sv), and White (Wt) - seven Republican appointees and two Democratic — as they result from 123 opinions dating from December 2, 1981, to July 7, 1986, that were issued by majorities issuing more than two opinions and where the most prolific majority authors forty-six opinions (37 percent of the opinions appearing in the graph). 


\section{F. The Kennedy Composition (1988-1990)}

The Kennedy composition is separated by one appointment from the O'Connor composition. The Chief Justice is now Rehnquist. Justice Scalia was nominated by Republican President Reagan and appointed on September 26, 1986. The departed justice was Chief Justice Burger. The Scalia composition, however, produces fewer than forty-five tightly split opinions, too few for a meaningful graphic. Justice Kennedy was also nominated by President Reagan and appointed on February 18, 1988, replacing Powell. The court produces eighty-nine tightly split opinions with this composition. The conservative core of the court is Rehnquist and Scalia. The liberal core is Blackmun, Brennan, and Marshall. White is the primary swing vote away from the main conservative coalition. Kennedy and O'Connor tie as its secondary swing votes. From the main liberal coalition, after White, the only swing vote is Stevens. A majority that issues a few liberal opinions (Blackmun, Brennan, Kennedy, Marshall, and Scalia) is not connected with a swing vote to any of the majorities that appear on the graph, a phenomenon that also arises in the Breyer and Alito compositions.

The conservative core joined by Kennedy and O'Connor constitutes the most productive coalition, the conservative coalition at the three o'clock position that authors forty-seven opinions. The dominant swing vote is White, producing the liberal majority at nine o'clock that authors twelve opinions, followed by a tie between Kennedy and O'Connor, whose swing votes produce the liberal majorities at the ten o'clock position and the eight o'clock position that author four opinions each. Stevens, the secondary swing from the main liberal coalition, produces the second conservative coalition authoring three opinions and consisting of Rehnquist, Kennedy, O'Connor, Scalia, and Stevens. 


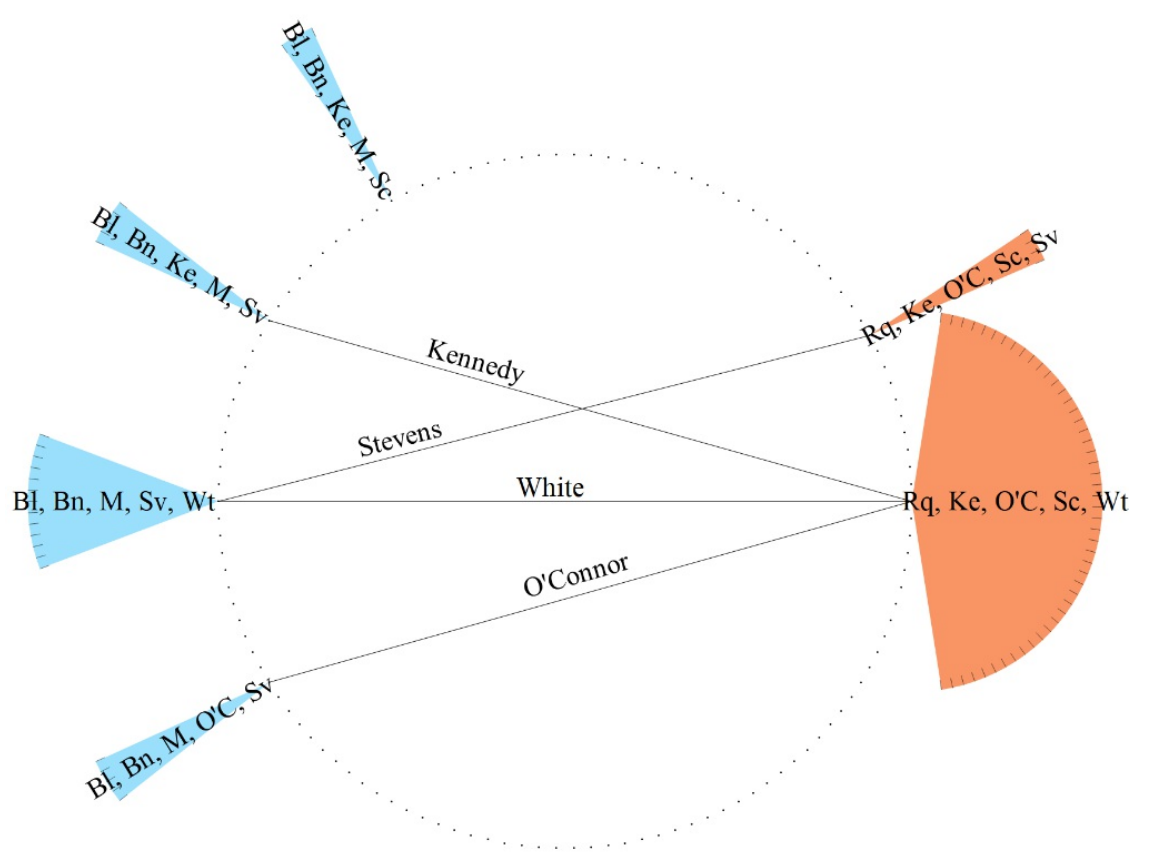

Figure 6. The swing votes of the 5-4 majorities of the Kennedy composition consisting of C.J. Rehnquist $(\mathrm{Rq})$ and Justices Blackmun (Bl), Brennan (Bn), Kennedy (Ke), Marshall (M), O’Connor (O’C), Scalia (Sc), Stevens (Sv), and White (Wt) - seven Republican appointees and two Democratic — as they result from seventythree opinions dating from April 25, 1988, to June 27, 1990, that were issued by majorities issuing more than two opinions and where the most prolific majority authors forty-seven opinions (64 percent of the opinions appearing in the graph).

The Kennedy composition, in having seven appointees of Republican presidents, shares that characteristic with the preceding compositions of Stevens and O'Connor. Nevertheless, the resulting graphic is quite different. Whereas in the prior two compositions that had seven Republican appointees, the court split to produce many different 5-4 coalitions, that is no longer the case. The Kennedy graph displays only six coalitions, whereas the graphs for Stevens and O'Connor displayed eleven and twelve coalitions. Moreover, only two of the Kennedy graph's coalitions predominate, whereas in the Stevens and the O'Connor graphs several of the coalitions issued similar and significant numbers of opinions.

\section{G. The Breyer Composition (1994-2005)}

The Breyer composition is separated from Kennedy's by several appointments. Souter and Thomas, appointed by Republican President G.H.W. Bush, replace Brennan and Marshall, respectively. Ginsburg and Breyer, appointed by Democratic President Clinton, replace White and Blackmun, respectively, and are the court's only Democratic appointees. The liberal core is Ginsburg, Souter, and Stevens. The conservative core is Rehnquist, Scalia, and Thomas. 
The conservative core joined by Kennedy and O'Connor constitutes the most productive coalition, the conservative coalition at the three o'clock position that authors eighty-six opinions. The dominant swing vote is O'Connor, producing the liberal majority at nine o'clock that authors thirty-one opinions, followed by Kennedy, whose swing vote produces the liberal majority at the ten o'clock position that authors eighteen opinions. Ginsburg, Stevens, and Souter are rare swing votes away from the liberal coalition.

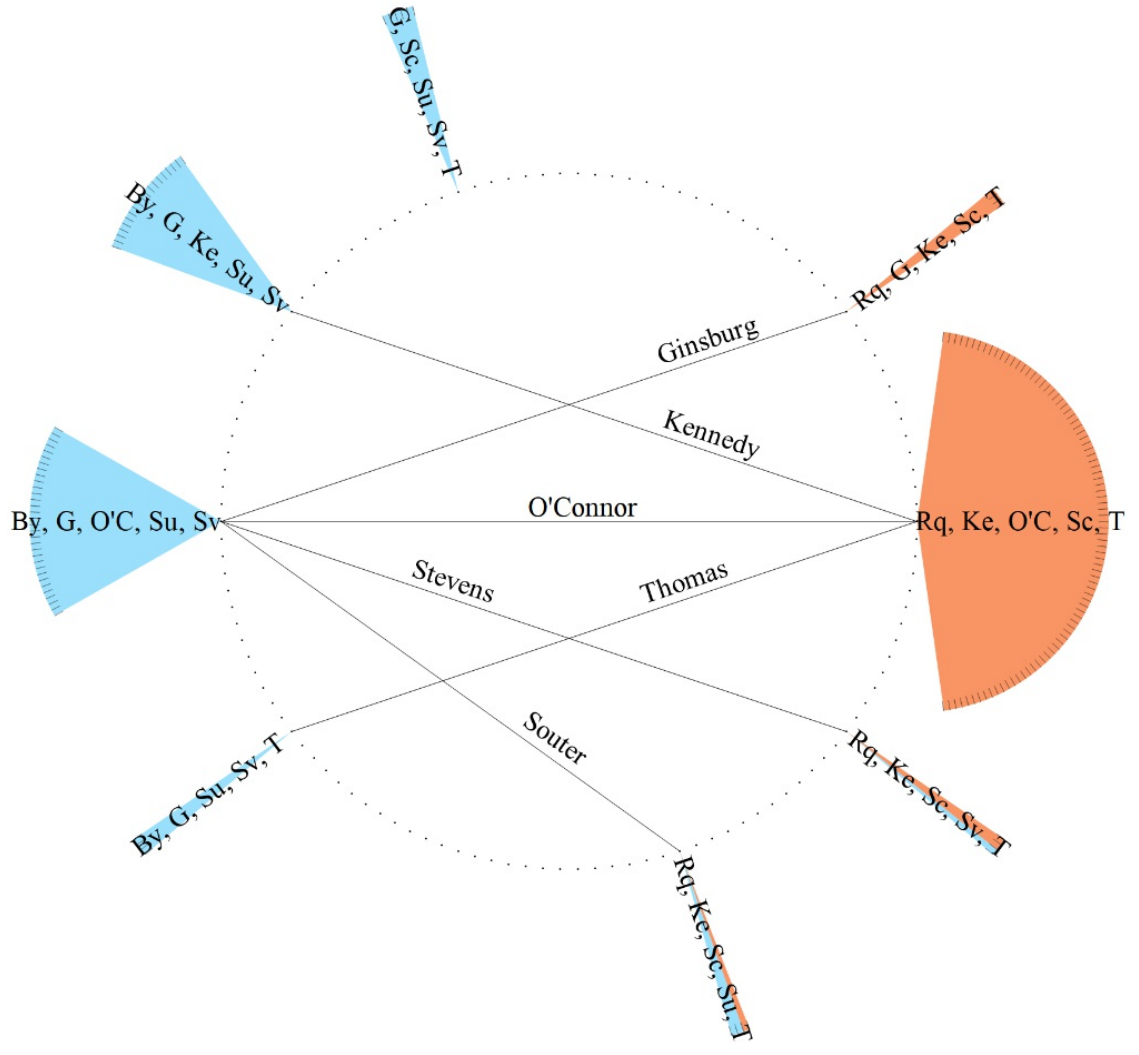

Figure 7. The swing votes of the 5-4 majorities of the Breyer composition of C.J. Rehnquist (Rq), Breyer (By), Ginsburg (G), Kennedy (Ke), O’Connor (O’C), Scalia (Sc), Souter (Su), Stevens (Sv), and Thomas (T) - seven Republican appointees and two Democratic - as they result from 152 opinions dating from November 14, 1994, to June 27, 2005, that were issued by majorities issuing more than two opinions and where the most prolific majority authors eighty-six opinions (57 percent of the opinions appearing in the graph).

\section{H. The Alito Composition (2006-09)}

The composition defined by Alito results from the departure of O'Connor and Rehnquist and their replacement by Alito and Roberts, appointed by Republican President G.W. Bush.

The Alito court - similarly to the next composition that we study, the Kagan 
court - presents strikingly few, only four, coalitions that form to produce three or more opinions. ${ }^{16}$

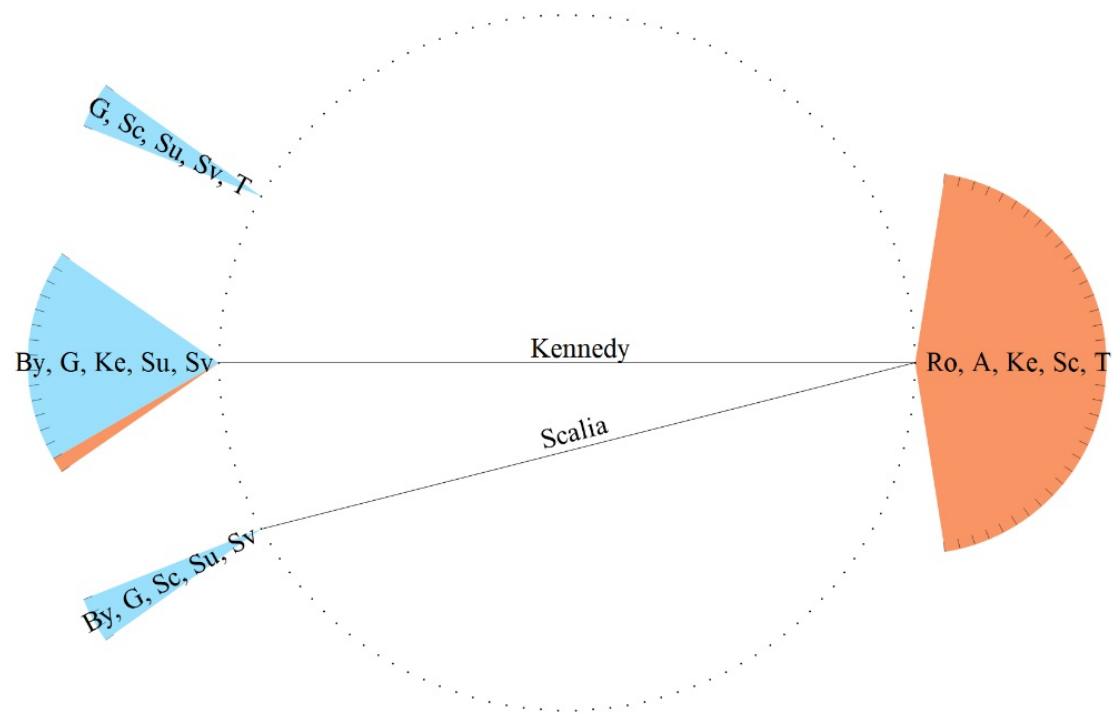

Figure 8. The swing votes of the 5-4 majorities of the Alito composition of C.J. Roberts (Ro) and Alito (A), Breyer (By), Ginsburg (G), Kennedy (Ke), Scalia (Sc), Souter (Su), Stevens (Sv), and Thomas (T)—-seven Republican appointees and two Democratic — as they result from fifty-six opinions dating from May 30, 2006, to June 29,2009 , that were issued by majorities issuing more than two opinions and where the most prolific majority authors thirty-five opinions (63 percent of the opinions appearing in the graph).

The dominant conservative majority, at the three o'clock position, produces thirty-five opinions and consists of Roberts, Alito, Kennedy, Scalia, and Thomas. The swing vote of Kennedy produces the dominant liberal majority, at the nine o'clock position, which authors fifteen opinions and consists of Breyer, Ginsburg, Kennedy, Souter, and Stevens. The other swing vote from the dominant conservative majority, the swing of Scalia, produces a majority that authors only three opinions, all liberal, and consists of Breyer, Ginsburg, Scalia, Souter, and Stevens. This appears at the eight o'clock position. One more liberal majority appears, formed by pulling both Scalia and Thomas from the conservative block, while the liberal majority loses Breyer to the conservative side. No single swing vote connects it with any of the prior majorities. It appears at the ten o'clock position and issues three liberal opinions.

Notice also that despite the apparent lack of fluidity of the Alito composition, the illustration still shows a contraslanted opinion: a barely conservative opinion

16. We drop one 5-4 opinion as not being a truly tightly split opinion; a merely apparent 5-4 split appears in Clark v. Arizona., 548 U.S. 735 (2006). One of the dissents, that of Breyer, actually agrees with the majority's interpretation but dissents for a remand instead of a reversal. $I d$. at 780 . 
from the main liberal majority. ${ }^{17}$ The next and last composition of the Supreme Court that we study, the one defined by Kagan as the junior justice, has no contraslanted opinions. ${ }^{18}$

\section{The Kagan Composition (2010-16)}

The composition defined by Kagan results from the departure of Stevens and Souter and their replacement by Kagan and Sotomayor by Democratic President Barack Obama. The Kagan composition, with four Democratic appointees, has the greatest number of Democratic appointees of any of the courts we study after the appointment of Stewart in 1958 tipped the court to majority Republican. The Democratic appointees are Breyer, Ginsburg, Kagan, and Sotomayor.

The Kagan composition has few tight majorities issuing more than two opinions. As in the case of the Alito composition, only four majorities produce more than two opinions and appear on the graph.

The dominant conservative majority, at the three o'clock position, produces thirty-three opinions and consists of Roberts, Alito, Kennedy, Scalia, and Thomas. The swing vote of Kennedy produces the dominant liberal majority, at the nine o'clock position, which authors twenty-three opinions and consists of Breyer, Ginsburg, Kagan, Kennedy, and Sotomayor. The other swing vote from the dominant conservative majority, that of Thomas, produces a liberal majority that authors only three opinions and consists of Breyer, Ginsburg, Kagan, Sotomayor, and Thomas. A conservative majority of a quite different composition, so that no single swing vote connects it with any of the prior majorities, appears at the four o'clock position and issues five opinions. This

17. Marrama v. Citizens Bank of Mass., 549 U.S. 365 (2007) (holding that bankruptcy courts have the authority to block abusive attempts to convert a chapter 7 filing into a chapter 13 proceeding; the dissent would allow no such discretion).

Outside of the majorities illustrated in the graphic, a single majority issues opinions with both conservative and liberal slants. The majority of Alito, Breyer, Ginsburg, Kennedy, and Stevens issues one liberal opinion and one conservative one.

The liberal opinion lets states deviate from the letter of the statute and ignore small school districts when following the statutory algorithm for equalizing per-pupil expenditures. Zuni Pub. Sch. Distr. No. 89 v. Dep't of Educ., 550 U.S. 81 (2007).

The conservative opinion allows states to assign to judges rather than juries the determination of the facts that trigger consecutive rather than concurrent running of sentences, an exception to Apprendi v. New Jersey, 530 U.S. 466 (2000). Oregon v. Ice, 555 U.S. 160, 172 (2009).

18. The Kagan composition, like the Alito one, has a single majority that issues one opinion of each slant. The majority that issues one opinion of each slant on the Alito composition is Alito, Breyer, Ginsburg, Kennedy, and Stevens. On the Kagan composition it is Roberts, Alito, Breyer, Scalia, and Thomas. That coalition could have arisen in the Alito composition. Yet, it did not. If it arose in the Alito composition, the dissenters would have been Ginsburg, Kennedy, Souter, and Stevens. The actual dissenters on the Kagan composition were Ginsburg, Kagan, Kennedy, and Sotomayor. 
majority takes the vote of Breyer from the liberal group but loses the vote of Scalia from the conservative group. It consists of Roberts, Alito, Breyer, Kennedy, and Thomas.

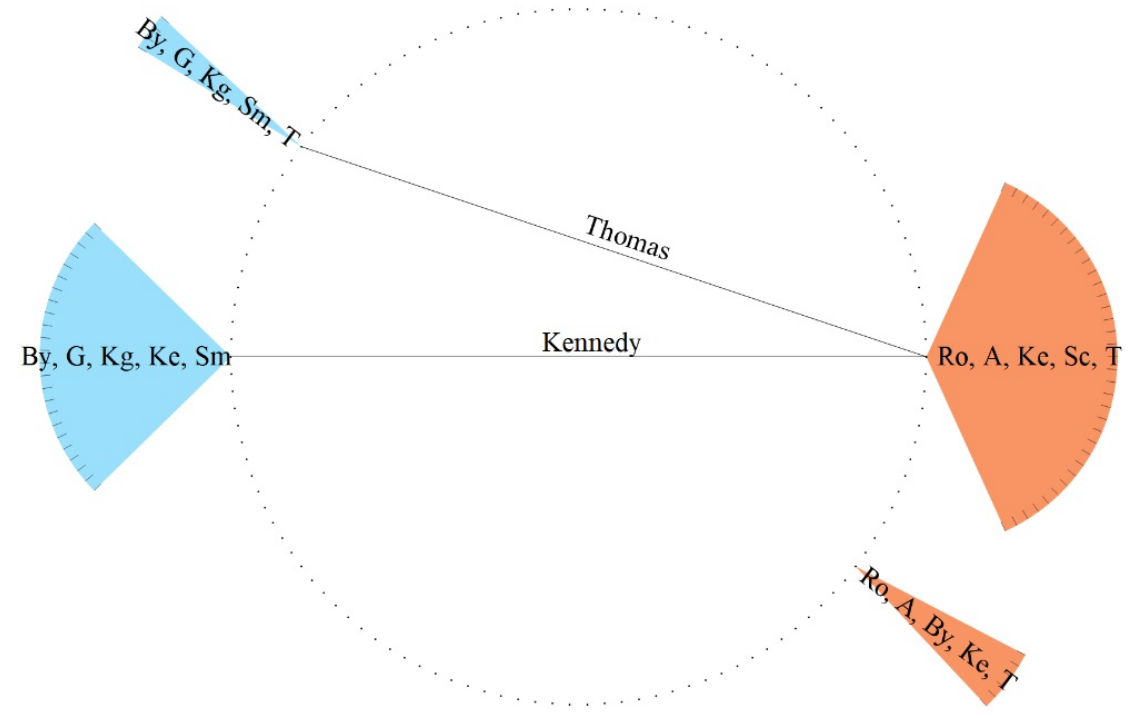

Figure 9. The swing votes of the 5-4 majorities of the Kagan composition of C.J. Roberts (Ro) and Alito (A), Breyer (By), Ginsburg (G), Kagan (Kg), Kennedy (Ke), Scalia (Sc), Sotomayor ( $\mathrm{Sm}$ ), and Thomas (T) - five Republican appointees and four Democratic - as they result from sixty-four opinions dating from March 29, 2011, to June 29, 2015, that were issued by majorities issuing more than two opinions and where the most prolific majority authors thirty-three opinions (52 percent of the opinions appearing in the graph).

\section{THE EBB AND FLOW OF FLUIDITY}

The primary phenomenon that this 1946-2016 graphical sojourn across 5-4 coalitions, their opinions, and the swing votes connecting them, reveals is first an increase and then a decrease of what we call fluidity. High fluidity corresponds to a court where justices coalesce in different ways to form many 5-4 coalitions, where each coalition issues a number of opinions similar to that of the other coalitions and many swing votes connect those coalitions. Low fluidity corresponds to a court that forms few coalitions, where even fewer coalitions dominate the issuance of opinions and few swing votes exist. Whereas making a consequentialist argument in favor of high or low fluidity must remain a future project, high fluidity corresponds to a truer collective nature of making decisions, as opposed to a court with a single swing vote, where some decisions effectively depend on a single vote.

The graphs reveal that in the 1946 to 2016 period that we study, fluidity tended to gradually increase, reached its maximum during the Stevens composition (1975-81), and then tended to gradually decrease. This phenomenon is in part visible in the graphs. The graphs corresponding to high fluidity- the compositions defined by Powell ('72-75), Stevens ('75-81), and O'Connor 
('81-86) - show that several coalitions issue opinions (seven to twelve), that the number of opinions each coalition issues is closer to proportional, while also having a multitude of swing votes (six to twelve, justices can appear more than once as swing votes between different coalitions). The graphs illustrating the opposite extreme of low fluidity are those of the compositions defined by Stewart ('58-62), Alito ('06-09), and Kagan ('10-16). They have few coalitions (three or four) with one or two coalitions dominating the issuance of opinions. They also have few swing votes (two or three). Moreover in the case of the Alito and Kagan compositions, a single swing vote dominates, that of Kennedy.

Table 2 collects metrics related to fluidity for the compositions illustrated by graphs above. The first three rows have the junior justice who defines the composition of the court, the calendar years of that composition, and the political composition of the court by appointing party, i.e., the number of justices appointed by presidents of each party. The Vinson composition is entirely nominated by Democratic presidents and the only one with a majority of Democratic appointees. Next, Stewart's composition is tightly split by party, which only arises again at the last composition we study, Kagan's.

The next two rows have, in row 4, the number of 5-4 coalitions that form in total and, in row 5, the number of 5-4 coalitions that appear on the graph (by issuing more than two opinions). Row 6 has the percentage that the coalitions that appear on the graph are as a fraction of the total number of coalitions formed.

Row 7 has the number of opinions issued by the most prolific coalition and row 8 that number as a fraction of the total number of opinions that appear on the graph, an imprecise metric but one that is high when fluidity is low because the busiest coalition issues many opinions, and which is low when fluidity is high, reflecting the fact that each coalition issues close to a proportional number of opinions. This follows the expected pattern. It is lowest during the Stevens composition and high during the compositions that have low fluidity, taking its highest value during the Stewart composition.

Row 9 has the number of swing votes that appear on the graph, again following the pattern by being high during the Powell, Stewart, and O'Connor compositions and low during the Vinson, Stewart, Alito, and Kagan ones.

In row 10 appears the index of fluidity, which we developed previously. ${ }^{19}$ Whereas it has the small fluctuations that a precise metric would tend to produce, we see a clear break between higher values (.43 and above) for the Vinson, Powell, Stevens, and O'Connor compositions and lower values (below .35) for the compositions of, Stewart, Kennedy, Breyer, Alito, and Kagan. 


\begin{tabular}{|c|c|c|c|c|c|c|c|c|c|c|}
\hline 1. & $\begin{array}{c}\text { Composition/ } \\
\text { Jr. Justice }\end{array}$ & Vinson & Stewart & Powell & Stevens & O'Connor & Kennedy & Breyer & Alito & Kagan \\
\hline 2. & Years & '46-49 & '58-62 & '72-75 & '75-81 & '81-86 & '88-90 & '94-05 & '06-09 & '10-16 \\
\hline 3. & $\begin{array}{c}\text { Appointing } \\
\text { party, R-D }\end{array}$ & $0-9$ & $5-4$ & $6-3$ & $7-2$ & $7-2$ & $7-2$ & $7-2$ & $7-2$ & $5-4$ \\
\hline 4. & Total coalitions & 28 & 19 & 23 & 33 & 33 & 19 & 35 & 14 & 13 \\
\hline 5. & Coalitions on graph & 5 & 3 & 7 & 11 & 12 & 6 & 8 & 4 & 4 \\
\hline 6. & Coal'n $\%$ on graph & $18 \%$ & $16 \%$ & $30 \%$ & $33 \%$ & $36 \%$ & $32 \%$ & $23 \%$ & $29 \%$ & $31 \%$ \\
\hline 7. & Most opin's by coalition & 33 & 40 & 37 & 19 & 46 & 47 & 86 & 35 & 33 \\
\hline 8. & Most as $\%$ of graph & $62 \%$ & $66 \%$ & $48 \%$ & $19 \%$ & $37 \%$ & $64 \%$ & $57 \%$ & $63 \%$ & $52 \%$ \\
\hline 9. & Swing on graph & 3 & 2 & 6 & 11 & 12 & 4 & 6 & 2 & 2 \\
\hline 10. & Fluidity index & .47 & .31 & .43 & .57 & .45 & .31 & .34 & .29 & .32 \\
\hline 11. & Contraslanted & 0 & 0 & 2 & 3 & 6 & 0 & 2 & 1 & 0 \\
\hline 12. & Contrasl'd \% of gr. & $0 \%$ & $0 \%$ & $2.6 \%$ & $3.1 \%$ & $4.9 \%$ & $0 \%$ & $1.3 \%$ & $1.8 \%$ & $0 \%$ \\
\hline
\end{tabular}

Table 2. Metrics Related to Fluidity.

A phenomenon that is not immediately related to the above understanding of fluidity is in harmony with the same pattern. We have mentioned that most coalitions only issue opinions of one political slant, either only conservative or only liberal opinions, and contraslanted are those opinions that have a political slant opposite to that of the majority of opinions of the coalition that issues them. The number of contraslanted opinions, in row 11, is very low, not allowing confident conclusions. Nevertheless, their percentage, in row 12, follows the pattern. The percentage of contraslanted opinions is higher during the courts with great fluidity, ranging from 2.6 percent to 4.9 percent. It is at its lowest during the compositions with low fluidity, being zero in three compositions (Vinson's, Stewart's, and Kagan's) and 1.8 percent during Alito's. Dearth of contraslanted opinions should appear during environments of more intense differences between members of the court. Abundance of contraslanted opinions, by contrast, should appear when the members of the court have less concern about the political aspects of adjudication. A composition with high fluidity should also be less politically polarized. Therefore, it should also be more likely to issue contraslanted opinions.

We return to the potential relevance of the political composition of the court by appointing party for fluidity. One can easily formulate a theory that a court dominated by a single party, i.e., that has a supermajority of justices (six or more in the case of a nine-member court) appointed by presidents of the same party, will tend to produce more fluidity. A court that is tightly split by its appointing party should be less fluid because, given that there will always be some quantity of issues on which the political parties are split, those issues will split the court 5-4; the appointees of one party in agreement with each other and in disagreement with the appointees of the other party, resulting in predictable and fixed coalitions. By contrast, if a supermajority (six or more) appointees are from the same party, what splits the court 5-4 will not be issues that split the parties; those issues will be decided by a supermajority vote. Rather, when such a court 
splits 5-4, those divisions will be less predictable and more varied. That would produce a more fluid court, a court that splits 5-4 in many ways, as opposed to the court that is tightly split by appointing party.

Appealing as this hypothesis may be, it has some but limited purchase in the data. Granted, the four most fluid courts that we see are all dominated by one party. The compositions defined by Vinson (dominated by Democratic appointees) and by Powell, Stevens, and O'Connor (dominated by Republican appointees) conform to the hypothesis. ${ }^{20}$ Moreover, as the hypothesis predicts, two of the least fluid courts are tightly split by appointing party. These are the compositions defined by Stewart and Kagan.

However, the Kennedy, Breyer, and Alito compositions contradict the hypothesis that dominance by one party produces fluidity, as do the Vinson composition's attributes other than its index. The Kennedy, Breyer, and Alito compositions had only two Democratic appointees (as did the Stevens and O'Connor compositions). Nevertheless, Kennedy's composition departed from the fluidity displayed by the preceding compositions of Stevens and O'Connor and this has continued with the Breyer, Alito, and Kagan compositions. Additional concerns, either at appointing time or during the tenure of the justices, may influence the court's fluidity in ways that the division by appointing party is too facile to capture. Perhaps, some of the appointees of Presidents Reagan and G.H.W. Bush, O'Connor, Scalia, Kennedy, Souter, and Thomas, may have been unlike the prior Republican appointees in ways that initiated a reduction of fluidity despite the appearance of continuity in the appointing party. We leave such speculation to others.

In sum, our primary contribution is that we observe an ebb and flow of fluidity. The phenomenon is supported by numerous additional metrics and, in turn, supports our index of fluidity by being consistent with it. However, these changes of fluidity are not amenable to simple analysis. Rather, we would like to flag fluidity as an important attribute of supreme courts that needs better understanding and is amply worthy of further analysis.

\section{LIMITATIONS OF LOCATIONAL MODELS}

The graphical and geometric nature of the graphs naturally lends itself to a comparison with locational models of adjudication. We find major discrepancies with the simpler median voter theorem but also with multidimensional models.

The median voter theorem takes a one-dimensional view of voting, from the political right to the political left. It posits that in an environment dominated by two parties, the party that obtains the vote of the median voter wins the elections. Effectively, voters are aligned in that one dimension. The central voter, the

20. A complication about the Vinson composition is that its high fluidity index is driven by having many coalitions which only produce one or two opinions and, therefore, do not appear on the graph. Otherwise, it exhibits all the phenomena of low fluidity: few visible coalitions, few swing votes, and no contraslanted opinions. 
median, breaks any tie, and the party that obtains that vote gets the majority. ${ }^{21}$

Simplistic as this model may be, applying it to adjudication is straightforward. One would arrange the justices on a single dimension, from right to left. The model suggests that the median justice's vote would resolve close cases, i.e., the 5-4 cases that we study here. Indeed, political scientists armed with big data computational methods have produced right-to-left ideological scorings of justices. ${ }^{22}$

If the ideological positions of each judge were precise and expressed with exactitude, then the median voter theorem would become a deterministic model that is utterly inconsistent with the data. Only two coalitions would exist in every composition of the court and the median justice would be the only swing vote. Giving the median voter theorem some additional complexity, the vote on each case would take additional uncertainty, effectively adding some randomness to each vote, perhaps corresponding to each judge's perception of each case being different, colored by various circumstances. This would allow judges to appear to have swapped positions, if, for example, a more liberal judge perceives a dispute as deserving a less liberal outcome while the next less liberal judge perceives it as deserving a more liberal one. In that version of the model, the outcomes would depend on the size of the variation that the added randomness would allow. If little variation existed, the model might lead to merely the occasional other swing vote, besides the true median. If a lot of variation were added, the model could produce many different coalitions and swing votes. The latter outcome seems unrealistic and the data does not conform to the notion of many random coalitions. The former would imply that the occasional second swing vote would be adjacent to the median. However, occasionally the second swing votes we see are far from the median, as was the case with Scalia and Thomas in recent compositions, and Rutledge during the composition defined by Vinson. Therefore, the data are incompatible with the simple locational model of the medial voter theorem, either in a version of accurate locations or one with added randomness.

Table 3 collects information comparing the ideological ranking of justices and the swing votes of each composition. Row 2 has the median justice according to the two leading ideological rankings of the justices (but only the first one, by Martin and Quinn, reaches Vinson's composition). Row 3 has the actual main swing vote, i.e., the vote that connects the busiest coalition to the next one linked by a swing vote. Whereas the main swing vote is included as one of the median voters in 13 of the potential 17 comparisons, true absolute agreement exists for only four of the nine compositions we study. In other words, the two ideological rankings and the main swing vote are only identified correctly and exclusively in four compositions: Powell's, Kennedy's, Alito's, and Kagan's. In all other compositions, the ideological rankings disagree or identify several different

21. The median voter theorem tracks its ancestry to Harold Hotelling, Stability in Competition, 39 ECON. J. 41-57 (1929).

22. See Martin \& Quinn, supra note3; Bailey, supra note 3. See also Ideological Leanings, supra note 3. 
median voters over the composition's duration. To the extent that the second ideological ranking purports to be an improvement, it identifies correctly only O'Connor as the median for Breyer's composition but performs more poorly than the original ranking in Stewart's composition, where only the original ranking included the actual main swing vote, Clark, as a median justice. Both ideological rankings fail in the Stevens composition, where the main swing vote is Powell, whom neither study includes as a median justice despite producing alternating median justices.

Row 4 has the number of opinions issued by the coalition to which the main swing vote goes - usually the second most active coalition. Those are the majorities that this swing vote creates when it swings away from the busiest coalition. Row 5 expresses this number as a percentage of the opinions that appear on the graph. Row 6 expresses this number as a percentage of the number of opinions issued by the most active coalition. When a single swing vote dominates, as does Kennedy's during the compositions defined by Alito and Kagan, those percentages are elevated.

Row 7 has the secondary swing vote, i.e., the one connecting the busiest coalition to the second most prolific linked coalition. Row 8 has the ideological ranking of that justice by the two rankings. In three compositions, Vinson's, Alito's, and Kagan's, the secondary swing vote has an ideological ranking far from the median. Rutledge is ranked as the most liberal member of the Vinson composition. Thomas is ranked at the conservative extreme of the Kagan composition. Scalia is ranked as the second most conservative member of the Alito composition. The tie of Kennedy and O'Connor as secondary swing votes during the Kennedy composition complicates their ranking, but O'Connor also appears as the second most conservative justice for a period of that composition but only according to the second ideological ranking, Bailey's. Whereas the median voter theorem, even with added randomness, would argue that the secondary swing vote should be adjacent to the median, that repeatedly fails to occur. Not rarely, the Supreme Court has had its secondary swing vote be far from the median.

\begin{tabular}{|c|c|c|c|c|c|c|c|c|c|c|}
\hline 1. & Composition/Jr. Justice & Vinson & Stewart & Powell & Stevens & O'Conor & Kennedy & Breyer & Alito & Kagan \\
\hline 2. & Median per M\&Q/B & $\begin{array}{c}\text { Reed } \\
\text { Frankf. } \\
\text { Burton }\end{array}$ & $\begin{array}{c}\text { Clark } \\
\text { Stewart/ } \\
\text { Frankf. } \\
\text { Stewart } \\
\text { Brennan }\end{array}$ & White & $\begin{array}{c}\text { White } \\
\text { Stewart } \\
\text { Blackm./ } \\
\text { White } \\
\text { Stewart }\end{array}$ & $\begin{array}{l}\text { White } \\
\text { Powell }\end{array}$ & White & $\begin{array}{l}\text { Kennedy, } \\
\text { O'Connor/ } \\
\text { O'Connor }\end{array}$ & Kennedy & Kennedy \\
\hline 3. & Main swing vote & Frankf. & Clark & White & Powell & White & White & O'Connor & Kennedy & Kennedy \\
\hline 4. & Swing to opinions & 7 & 11 & 10 & 7 & 20 & 12 & 31 & 15 & 23 \\
\hline 5. & Main sw as $\%$ of graph & $13 \%$ & $18 \%$ & $10 \%$ & $7 \%$ & $16 \%$ & $16 \%$ & $20 \%$ & $27 \%$ & $36 \%$ \\
\hline 6. & As $\%$ of most active & $21 \%$ & $28 \%$ & $27 \%$ & $37 \%$ & $43 \%$ & $26 \%$ & $36 \%$ & $43 \%$ & $70 \%$ \\
\hline 7. & Secondary swing vote & Rutledge & Stewart & Powell & Blackm. & Powell & K, O'C & Kennedy & Scalia & Thomas \\
\hline 8. & Rank per M\&Q/B & $7-9$ & $4 / 3-5$ & 4 & $3 / 3,4,6$ & $4-5 / 3-5$ & $3,4 / 2,3,4$ & $5,4 / 4$ & $2 / 3$ & 1 \\
\hline 9. & Swing to opinions & 4 & 10 & 3 & 3 & 16 & 4 & 18 & 3 & 3 \\
\hline 10. & Sec'ry sw as $\%$ of main & $57 \%$ & $90 \%$ & $30 \%$ & $43 \%$ & $80 \%$ & $33 \%$ & $58 \%$ & $20 \%$ & $13 \%$ \\
\hline
\end{tabular}


A related discrepancy with the median voter theorem comes from comparing the Powell composition to that of Stevens. The membership of the court changed by a single member, by the replacement of Douglas by Stevens. Douglas was by far the most liberal member of the court. Admittedly, Stevens, despite being the nominee of Republican President Ford, was not very conservative. (Stevens appears on the liberal side of that court of seven Republican appointees.) For evaluating the median voter theorem, the point is that the replacement of far-left Douglas with the moderate Stevens did not change the median justice. In a direct contradiction of the median voter theorem, when Stevens replaces Douglas, the main swing vote changes from White to Powell.

Granted, the one-dimensional nature of the median voter theorem is simplistic, making its rejection by the data unremarkable. However, this data reveals a phenomenon that shows that even locational models with many dimensions cannot be durable. Despite that an ideal model with many dimensions could capture nuance, it could still not account for the creation of new dimensions. Adjudication by supreme courts, however, often creates new dimensions, adding new tests or elements for a legal conclusion, or removing them by overruling such precedent. An illustration of a creation of a new test, i.e., a new dimension from the perspective of locational modelling, in criminal procedure arises in the Apprendi line of cases in this data.

Apprendi is about criminal procedure, interpreting due process and the right to a jury trial in the context of sentencing enhancements. ${ }^{23}$ Sentencing enhancements increase criminal penalties in specific circumstances. In the example of Apprendi's facts, the penalty increased due to racial animus in the commission of the crime. The Apprendi line of opinions holds that facts which increase the maximum sentence must be found by the jury beyond a reasonable doubt. Thus, even if a fact is not an element of the crime, if this fact triggers an increase of the maximum penalty, then Apprendi requires it to be treated the same way that elements of the crime are. In a trial, the jury must establish this fact beyond reasonable doubt. The majority that produced Apprendi appears at the 11 o'clock position of the Breyer graph and has the additional feature that this majority only formed to issue the Apprendi line of opinions and one unrelated opinion on tort liability. ${ }^{24}$ Moreover, this majority has no swing votes linking it with the others of the graph. It draws two votes from the conservative side of the court, Scalia and Thomas. Also, it fails to draw Breyer's vote from the liberal side of the court.

Suppose that a locational model of criminal procedure had been created before the first of the Apprendi opinions were issued, i.e., before Jones. This model completely described criminal procedure and each justice's attitudes about every aspect of it. The model would be a perfect description of criminal procedure and would perfectly predict every vote of every justice on every criminal procedure issue. Despite its completeness, however, this model of criminal procedure would use inferences from prior precedent to answer the

23. Apprendi v. New Jersey, 530 U.S. 466 (2000).

24. See infra Appendix A, text accompanying notes 23-27. 
question whether penalty enhancements should be found by juries beyond reasonable doubt - to wit, not the Apprendi holding. Moreover, the justices' other positions on criminal procedure did not foretell their position on this issue, because this was a unique coalition. In other words, this complete model of criminal procedure would be rendered obsolete by the Apprendi line of cases because they created a new dimension in criminal procedure. The fact that this new dimension involved a coalition that had not formed for any other issue of criminal procedure underscores its novelty and that it could not have been predicted by the previously correct model. ${ }^{25}$

\section{CONCLUSION}

Fluidity is an important attribute of adjudication by supreme courts. Our graphical presentation of the coalitions, the swing votes, and the opinions of supreme court compositions allowed not only a quantitative approach to fluidity but also a visual one. We hope this opens avenues for further research.

We submit that this analysis refutes the possibility of having locational models of either the level of generality of the median voter theorem or of the level of complete specificity that would account for every interpretation. The median voter theorem fails because (a) the most active swing vote is often not the median by ideology justice; (b) the second most active swing vote is often far from the ideological median; and (c) the pattern of coalitions does not conform to the predictions of the median voter theorem, which would call for two dominant coalitions plus additional coalitions due to noise. A locational model of complete specificity is refuted by the creation of new and unexpected coalitions (and dimensions), as exemplified by the Apprendi coalition.

This analysis also has relevance about the efficiency of the common law and plaintiffs' victory rate, inviting further research in those directions. The argument about the efficiency of the common law rests on the notion that ineffective interpretations would attract litigation, which would lead to their alteration. Support for this hypothesis may stem from the persistence of the litigation about Un-American Activities Committees that appears in the Stewart composition. To the extent those results were not in harmony with straightforward understandings of the First Amendment, their repeated litigation despite repeated 5-4 losses supports the premise that some outcome (arguably inefficient) will attract litigation. The persistence of the litigation without a change of outcome during that composition does not support the conclusion that the repeated litigation will change the law. However, the predominance of criminal procedure in all compositions may serve as a counterexample. In the Vinson composition, we see the Court stating that the Constitution must not be interpreted so as to dictate to

25. In Appendix A we pursue the information contained in the swing votes connecting the Apprendi coalition to the coalitions issuing one or two opinions and which, therefore, do not appear on the graph. Only one helps explain a likely change in Justice Thomas, again underlining the novelty and unpredictability of the Apprendi line of cases. 
the states their criminal procedure. ${ }^{26}$ By today's standards, that is a quaint anachronism. Federal criminal procedure dominates that of the states, despite herculean efforts by the legislature to limit the involvement of the federal judiciary, for example by limiting habeas corpus jurisdiction. ${ }^{27}$ The argument that this outcome - the subsuming of state criminal procedure by federal Constitutional interpretation - is efficient, seems quite difficult to make. More likely, this is an expression of a different premise, that what attracts litigation is not inefficient interpretations about criminal procedure but every conviction with a colorable Constitutional argument. The result, then, would not be a more efficient criminal procedure law but, at least, a more federalized criminal procedure.

Turning to expected rates of victory, it is striking that in all compositions - from the all-Democratic-appointee Vinson composition, to the heavily Republican-appointee courts of 1972 to 2010 - the outcomes skew conservative and the rate of conservative outcomes is almost constant. Because the Court, through the process of granting certiorari, determines its own docket, any conclusions will not reflect the decisions of plaintiffs and defendants but the process of granting certiorari. A process that selected disputes for being on the cusp of a divided court, should tend to produce outcomes that would be more evenly split. That in all compositions a conservative skew appears likely suggests additional complexities in the selection of disputes.

26. Carter v. Illinois, 329 U.S. 173, 175 (1946) ("[T]he Due Process Clause has never been perverted so as to force upon the forty-eight States a uniform code of criminal procedure.")

27. See, e.g., Antiterrorism and Effective Death Penalty Act of 1996, Pub. L. No. 104-132, 110 Stat. 1214 (1996); Prison Litigation Reform Act of 1996, 42 U.S.C. § 1997(e) (1996) (both imposing procedural requirements designed to limit litigation). 


\section{APPENDIX A: THE SWING VOTES OF THE APPRENDI MAJORITY OFFER NO INFERENCES}

The main text, text accompanying notes 21-22, explained how the Apprendi line of cases shows that adjudication by supreme courts can create new unanticipated dimensions that render obsolete even a previously accurate multidimensional locational model of law. This appendix buttresses this conclusion by showing that exploring the swing votes from the Apprendi coalition does not reveal an ability to forecast Apprendi and its line.

The Apprendi majority appears at the eleven o'clock position of the Breyer court and issues five opinions. The majority is Ginsburg, Scalia, Souter, Stevens, and Thomas.

Four of the five opinions that this majority produces are in the Apprendi line, that aggravating factors of sentences must be proven beyond reasonable doubt to the jury. Those are, first, a precursor to Apprendi, ${ }^{28}$ Apprendi itself, ${ }^{29}$ and two applications of the principles of Apprendi to state courts, ${ }^{30}$ and federal courts. ${ }^{31}$ The fifth opinion is unrelated, about asbestosis claimants under the Federal Employers Liability Act where the dissent would limit damages. ${ }^{32}$ Thus, the political slant of all five decisions is liberal, the Apprendi group for impeding criminal liability and the last one for facilitating civil liability.

Going back to the list of the majorities of the Breyer composition that authored up to two opinions and, therefore, are not on the graph, reveals three majorities that connect to the Apprendi majority by one swing vote.

The swing vote of Scalia produces the majority of Rehnquist, Breyer, Kennedy, O'Connor, and Scalia, which authors two opinions. One is a tort dispute, where the court absolves from liability a car manufacturer. ${ }^{33}$ The other one, Harris, is a criminal procedure dispute, and appears contrary to Apprendi. ${ }^{34}$ However, the majority opinion clarifies that Apprendi applies to aggravating factors that increase the penalty beyond the statutory maximum of the crime found by the jury, whereas Harris involves an increase of the minimum penalty. Thus, the juxtaposition of Harris explains exactly where Scalia's vote changes but on this very narrow issue without helping predict that this swing would come. The Harris issue also underscores the unsystematic nature of the Apprendi majority by the return of the same issue during the Kagan composition. This time

28. Jones v. United States, 526 U.S. 227 (1999).

29. Apprendi v. New Jersey, 530 U.S. 466 (2000).

30. Blakely v. Washington, 542 U.S. 296 (2004).

31. United States v. Booker, 543 U.S. 220 (2005). Booker is a microcosm of the point we make in this appendix. In the first part of Booker, the Apprendi majority holds for the first time that the Apprendi principle applies to federal crimes. But there is a second part to Booker in which a different 5-4 held that the federal sentencing guidelines were discretionary and, therefore, not subject to Apprendi's mandate.

32. Norfolk \& Western Ry. Co. v. Ayers, 538 U.S. 135 (2003).

33. Geier v. Am. Honda Motor Co., 529 U.S. 861 (2000) (no manufacturer liability for absence of side airbags; explicitly disapproving this one pro-tort-liability opinion of co-author Sullivan, who consistently opposed tort liability).

34. Harris v. United States, 536 U.S. 545 (2002) (aggravating factor of brandishing gun allowed to be found by judge). 
Scalia did not join Thomas; Breyer switched sides; and the new Democratic appointees, Kagan and Sotomayor, joined. Thus, Breyer, Ginsburg, Kagan, Sotomayor, and Thomas form a majority that holds that facts supporting enhancements to minimum criminal penalties do require proof beyond reasonable doubt to the jury. ${ }^{35}$

The swing vote of Thomas away from the Apprendi majority produces the majority of Rehnquist, Breyer, Kennedy, O'Connor, and Thomas, which also authors two conservative opinions, both on criminal procedure. The first is contrary to Apprendi and is about deported aliens who reenter the United States. ${ }^{36}$ While the reentry increases the criminal penalty very significantly, from two to twenty years' maximum incarceration, the court does not consider it an element of the offense, letting it escape the type of scrutiny that Apprendi would impose, over a dissent by Scalia to that exact point. The other opinion of the same majority is about double jeopardy in the context of California's three-strikes law and allows the three-strikes trial to establish the prior offense. ${ }^{37}$ However, these two opinions predate both Apprendi and its precursor, Jones, which makes the contradiction of the vote of Thomas less acute. Apparently, Thomas's view on the Apprendi issue changed by the time he voted in Jones, something that no locational model could predict.

The third majority that is separated by one swing vote from the Apprendi majority arises from the swing vote of Souter. The dispute is unrelated to criminal procedure and therefore offers no insight into the fulcrum point of the vote of Souter in the Apprendi line of cases. ${ }^{38}$ It certainly would not help predict his swing to the Apprendi majority.

A fourth majority is also separated by one swing vote from the Apprendi majority: ironically enough, the second part of United States v. Booker, the application of Apprendi to federal courts discussed in note 30, above. The swing vote is Ginsburg and the effect of her joining with Breyer, Kennedy, O'Connor, and Rehnquist is that the Apprendi principle does not apply to federal sentencings, hardly predictable by her being part of the Apprendi majority!

In sum, despite our probing of potential swing votes, we find no hints that a locational model could have use to predict the formation of the Apprendi majority.

35. At the ten o'clock position of the graph for the Kagan composition, the majority of Breyer, Ginsburg, Kagan, Sotomayor, and Thomas, which produces only three opinions, also expands on Apprendi by requiring its treatment to enhancements of minimum penalties. See Alleyne v. United States, 570 U.S. 99 (2013).

36. Almendarez-Torres v. United States, 523 U.S. 224 (1998).

37. Monge v. California, 524 U.S. 721 (1998).

38. The resulting majority is Rehnquist, Breyer, Kennedy, O'Connor, and Souter, which authors a single opinion. Am. Ins. Ass'n v. Garamendi, 539 U.S. 396 (2003). The legal subject matter of Garamendi is not easy to categorize. California passed a statute requiring insurance companies that did business in Europe during World War II to disclose to its insurance commissioner details about their life insurance policies on holocaust victims, about which the President of the United States had entered into an agreement with Germany. The court invalidated the statute as being in conflict with the President's authority to conduct foreign affairs. The result can be considered conservative for precluding liability and liberal for not granting the state the right it sought. 


\section{APPENDIX B: TABLES OF OPINIONS}

\section{Appendix B1: Tables of Vinson Composition Majorities Producing More than Two 5-4 Opinions}

We list the opinions of the United States Supreme Court while its composition is defined by its junior justice being Chief Justice Vinson. The Vinson composition consisted of nine appointees of Democratic presidents: The Vinson composition consists of nine appointees of Democratic presidents (Black, Burton, Douglas, Frankfurter, Jackson, Murphy, Reed, Rutledge, and Vinson). We list the majorities as they appear in the corresponding figure in the full-text proceeding clockwise from the nine o'clock position. The name of the case, along with the citation to the United States Reporter, and the year appears in the first column. The second column holds our brief description of the outcome compared to the dissent's position. The third column holds the legal field and the political slant of the majority's position as it arises by juxtaposition to that of the minority. We sort the justices in the majorities by, first, the chief justice, then the associate justices by alphabetical order.

\section{BLACK-DOUGLAS-FRANKFURTER-MURPHY-RUTLEDGE (NINE O'CLOCK)}

\begin{tabular}{|c|c|c|}
\hline $\begin{array}{l}\text { Haley v. } \text { Ohio, } \\
332 \text { U.S. } 596 \\
(1948) .\end{array}$ & $\begin{array}{l}\text { Reversal due to coerced confession. Dissent (Burton with all), } \\
\text { "Self-serving perjury, however, must not be the passkey to a } \\
\text { mandatory exclusion of the confession from use as evidence. } \\
\text { It is for the trial judge and the jury . . . to determine the } \\
\text { voluntary nature of a confession." }\end{array}$ & CrimPro, liberal \\
\hline $\begin{array}{l}\text { Wade v. Mayo, } 334 \\
\text { U.S. } 672 \text { (1948). }\end{array}$ & $\begin{array}{l}\text { Reversing conviction on habeas: "The Circuit Court of Appeals } \\
\text { [which upheld conviction] was therefore in error . . . in } \\
\text { assuming that the failure to appoint counsel in a non-capital } \\
\text { case in a state court is a denial of due process under the } \\
\text { Fourteenth Amendment only if the law of the state requires } \\
\text { such an appointment." Dissent (Reed with all) would deny } \\
\text { habeas because defendant obtained counsel before his state } \\
\text { remedies were exhausted and failed to appeal properly. }\end{array}$ & CrimPro, liberal \\
\hline $\begin{array}{l}\text { Upshaw v. United } \\
\text { States, } 335 \text { U.S. } \\
410(1948) .\end{array}$ & $\begin{array}{l}\text { Repeated interrogations before taking defendant to a magistrate } \\
\text { for commitment are grounds for reversal. Dissent (Reed) } \\
\text { advises changing the rules about admissibility of evidence } \\
\text { "only when 'fundamentally altered conditions,' call for such a } \\
\text { change in the interests of justice." (Citation omitted). }\end{array}$ & CrimPro, liberal \\
\hline $\begin{array}{l}\text { T u r n e r } \quad \text { v } \\
\text { Pennsylvania, } 338 \\
\text { U.S. } 62 \text { (1949). }\end{array}$ & $\begin{array}{l}\text { Reversing conviction on coerced confession. Dissent } 1 \\
\text { (Jackson in Watts v. Indiana, } 338 \text { U.S. } 49 \text { (1949)), "I doubt } \\
\text { very much if [constitutional principles] require us to hold that } \\
\text { the State may not take into custody and question one suspected } \\
\text { reasonably of an unwitnessed murder. If it does, the people of } \\
\text { this country must discipline themselves to seeing their police } \\
\text { stand by helplessly while those suspected of murder prowl } \\
\text { about unmolested." Dissent } 2 \text { without opinion. }\end{array}$ & CrimPro, liberal \\
\hline $\begin{array}{l}\text { Harris v. South } \\
\text { Carolina, } 338 \text { U.S. } \\
68 \text { (1949). }\end{array}$ & $\begin{array}{l}\text { Reversing conviction on coerced confession. Dissents as in } \\
\text { Turner, } 338 \text { U.S. } 62 \text {. }\end{array}$ & CrimPro, liberal \\
\hline
\end{tabular}




\begin{tabular}{|l|l|l|}
\hline $\begin{array}{l}\text { Lustig v. United } \\
\text { States, 338 U.S. 74 } \\
\text { (1949). }\end{array}$ & $\begin{array}{l}\text { Reversing conviction on warrantless search. Dissent (Reed } \\
\text { with all), evidence is admissible because the federal agent did } \\
\text { not participate in its procurement by the state police. }\end{array}$ & CrimPro, liberal \\
\hline $\begin{array}{l}\text { Christ offel v. } \\
\text { United States, 338 }\end{array}$ & $\begin{array}{l}\text { Reversing perjury conviction before Congressional committee } \\
\text { for lack of quorum. Dissent (Jackson with all), "the Court is } \\
\text { Uenying to the records of the Congress and its committees the } \\
\text { credit and effect to which they are entitled." }\end{array}$ & CrimPro, liberal \\
\hline
\end{tabular}

\section{BLACK-DOUGLAS-MuRPHY-REED-RUTLEDGE (TEN O'ClOCK)}

\begin{tabular}{|c|c|c|}
\hline $\begin{array}{l}\text { NLRB v. Jones \& } \\
\text { Laughlin Steel } \\
\text { Corp., } 331 \text { U.S. } \\
416 \text { (1947). }\end{array}$ & $\begin{array}{l}\text { Collective bargaining with guards that were deputized military } \\
\text { auxiliaries was not contrary to public safety. Dissent (all), } \\
\text { without opinion, referring to that of the court below. }\end{array}$ & Labor, liberal \\
\hline $\begin{array}{l}\text { Memphis Natural } \\
\text { Gas Co. v. Stone, } \\
\text { 335 U.S. } 80 \text { (1948). }\end{array}$ & $\begin{array}{l}\text { Upholding franchise tax on pipeline for the fractional value of } \\
\text { its pipeline in the state. Dissent (Frankfurter with all), because } \\
\text { local taxes had been paid to the local authorities, "where the } \\
\text { only 'local incident' is the fact of interstate commerce-that the } \\
\text { interstate pipeline goes through Mississippi-the tax is } \\
\text { necessarily a tax upon the privilege of doing interstate } \\
\text { business." }\end{array}$ & Tax, liberal \\
\hline $\begin{array}{l}\text { Vermilya-Brown } \\
\text { Co. v. Connell, } 335 \\
\text { U.S. } 377 \text { (1948). }\end{array}$ & $\begin{array}{l}\text { Upholding application of Fair Labor Standards Act on a } \\
\text { military base in Bermuda. Dissent (Jackson with all), "[t]o } \\
\text { consider the bases as possessions ... is incompatible with the } \\
\text { spirit of the negotiations [with the UK] and with the letter of } \\
\text { the lease by which the bases were acquired." }\end{array}$ & Labor, liberal \\
\hline $\begin{array}{l}\text { Terminiello v. } \\
\text { Chicago, } 337 \text { U.S. } \\
1 \text { (1949). }\end{array}$ & $\begin{array}{l}\text { Reversing conviction of disturbing the peace on indoor } \\
\text { assembly that garnered opposition and disturbances, political } \\
\text { speech by nature attracts dissent. Dissent } 1 \text { (Vinson), "the } \\
\text { Illinois courts construed the ordinance as punishing only the } \\
\text { use of 'fighting words."' Dissent } 2 \text { (Frankfurter), "[i]f the Court } \\
\text { refrained from taking phrases out of their environment and } \\
\text { finding in them a self-generated objection, it could not be } \\
\text { deemed to have approved of them even as abstract } \\
\text { propositions." Dissent } 3 \text { (Jackson with Burton), the Court } \\
\text { "fixes its eyes on a conception of freedom of speech so rigid as } \\
\text { to tolerate no concession to society's need for public order." }\end{array}$ & Speech, liberal \\
\hline $\begin{array}{l}\text { United States v. } \\
\text { Cors, } 337 \text { U.S. } 325 \\
\text { (1949). }\end{array}$ & $\begin{array}{l}\text { Compensation for requisitioned tugboat must not include rise } \\
\text { in value due to Government's demand. Dissent (Frankfurter } \\
\text { with Burton \& Jackson; Vinson no opinion), rise in value is } \\
\text { due to demand from rest of market, not government, and must } \\
\text { be included in the compensation. }\end{array}$ & Takings, libera \\
\hline
\end{tabular}




\section{VINSON-BLACK-BURTON-DOUGLAS-REED (TWO O'CLOCK)}

\begin{tabular}{|c|c|c|}
\hline $\begin{array}{l}\text { Harris v. United } \\
\text { States, } 331 \text { U.S. } \\
145 \text { (1947). }\end{array}$ & $\begin{array}{l}\text { FBI may search home incident to arrest. Dissent } 1 \text { (Frankfurter } \\
\text { with Murphy and Rutledge), "searches are 'unreasonable' } \\
\text { unless authorized by a warrant [with] adequate safeguards." } \\
\text { Dissent } 2 \text { (Murphy), "A warrant of arrest, without more, is now } \\
\text { sufficient to justify an unlimited search of a man's home..." } \\
\text { Dissent } 3 \text { (Jackson), "I see no practical limit [of the scope of } \\
\text { the search] short of that set in the opinion ... - and that means } \\
\text { to me no limit at all." }\end{array}$ & $\begin{array}{l}\mathrm{C} \text { r i m P r o, } \\
\text { conservative }\end{array}$ \\
\hline $\begin{array}{l}\text { Shapiro v. United } \\
\text { States, } 335 \text { U.S. } 1 \\
\text { (1948). }\end{array}$ & $\begin{array}{l}\text { Records, which merchant must by statute keep, are not subject } \\
\text { to immunity because they are public records. Dissent } 1 \\
\text { (Frankfurter), "The Court this day decides that when Congress } \\
\text { prescribes ... the form in which some records are to be kept, } \\
\text { not by corporations but by private individuals, in what in } \\
\text { everyday language is a private and not a Governmental } \\
\text { business, Congress thereby takes such records out of the } \\
\text { protection of the Constitution against self-incrimination and } \\
\text { search and seizure." Dissent } 2 \text { (Jackson with Murphy), "The } \\
\text { protection against compulsory self-incrimination, guaranteed } \\
\text { by the Fifth Amendment, is nullified to whatever extent this } \\
\text { Court holds that Congress may require a citizen to keep an } \\
\text { account of his deeds and misdeeds and turn over or exhibit the } \\
\text { record on demand of government inspectors, who then can use } \\
\text { it to convict him." Dissent 3, (Rutledge), nor is the decision } \\
\text { consistent with the statute. }\end{array}$ & $\begin{array}{l}\mathrm{C} \text { r i m P r o, } \\
\text { conservative }\end{array}$ \\
\hline $\begin{array}{l}\text { United States v. } \\
\text { Hoffman, } 335 \text { U.S. } \\
77 \text { (1948). }\end{array}$ & $\begin{array}{l}\text { Companion case to Shapiro, } 335 \text { U.S. 1, slight differences } \\
\text { (improper appeal, records not produced under oath), same } \\
\text { outcome without opinion, same dissenters, referring to their } \\
\text { opinions in Shapiro. }\end{array}$ & $\begin{array}{l}\text { C r i m P r o, } \\
\text { conservative }\end{array}$ \\
\hline $\begin{array}{l}\text { Nye \& Nissen v. } \\
\text { United States, } 336 \\
\text { U.S. } 613 \text { (1949). }\end{array}$ & $\begin{array}{l}\text { Upholding conviction of aiding fraud on the United States in } \\
\text { sales of dairy items to the military using fraudulent invoices, } \\
\text { reversing conspiracy conviction. Dissent } 1 \text { (Frankfurter with } \\
\text { Jackson and Rutledge), "Now that the theory has been rejected } \\
\text { which made it unnecessary for the Court of Appeals to pass on } \\
\text { the sufficiency of the evidence to support the charge of aiding } \\
\text { and abetting, we should remand the case so that it may do so." } \\
\text { Dissent } 2 \text { (Murphy), "[T]he Court holds that failure to instruct } \\
\text { of the relationship between conspiracy and aiding or abetting } \\
\text { is unimportant. I cannot agree." }\end{array}$ & $\begin{array}{l}\text { C r i m P r o, } \\
\text { conservative }\end{array}$ \\
\hline
\end{tabular}




\section{VINSON-BURTON-FRANKFURTER-JACKSON-REED (THREE O'CLOCK)}

\begin{tabular}{|c|c|c|}
\hline $\begin{array}{l}\text { Carter v. Illinois, } \\
329 \text { U.S. } 173 \\
(1946) .\end{array}$ & $\begin{array}{l}\text { Not all criminal defendants have a right to counsel, } \\
\text { (Frankfurter: "the Due Process Clause has never been perverted } \\
\text { so as to force upon the forty-eight States a uniform code of } \\
\text { criminal procedure.") Dissent } 1 \text { (Douglas with Black and } \\
\text { Rutledge) would remand, "there is ample evidence in the } \\
\text { record ... to support petitioner's claim that he was not capable } \\
\text { of making his defense." Dissent } 2 \text { (Murphy), "there is no } \\
\text { affirmative indication that he intelligently waived his right to } \\
\text { counsel or that he understood the intricate legal problems } \\
\text { involved in his indictment and conviction." }\end{array}$ & $\begin{array}{l}\mathrm{C} \text { r i m P r o, } \\
\text { conservative }\end{array}$ \\
\hline $\begin{array}{l}\text { United States v. } \\
\text { United Mine } \\
\text { Work ers of } \\
\text { America, } 330 \text { U.S. } \\
258 \text { (1947). }\end{array}$ & $\begin{array}{l}\text { Plurality upholds contempt conviction of mineworkers' union } \\
\text { for enjoined strike. Concurrence } 1 \text { (Jackson), without opinion. } \\
\text { Concurrence } 2 \text { (Frankfurter) would not exclude application of } \\
\text { labor legislation because the government is a party. Dissent } 1 \\
\text { (Black with Douglas) finds the fines excessive and would } \\
\text { require that they be conditional on not complying with the } \\
\text { court order. Dissent } 2 \text { (Murphy), the dispute was clearly a labor } \\
\text { dispute, therefore subject to the corresponding legislation and } \\
\text { injunction violated the statute. Dissent } 3 \text { (Rutledge with } \\
\text { Murphy), "Congress has forbidden the use of labor injunctions } \\
\text { in this and like cases, that conclusion is the end of our } \\
\text { function." }\end{array}$ & $\begin{array}{l}\mathrm{L} \text { a } \mathrm{b} \text { o } \mathrm{r}, \\
\text { conservative }\end{array}$ \\
\hline $\begin{array}{l}\text { Joseph v. Carter \& } \\
\text { W e e k e s } \\
\text { Stevedoring } \\
330 \text { Co., } \\
(1947) .\end{array}$ & $\begin{array}{l}\text { Tax on general receipts of loading and unloading interstate } \\
\text { freight boats and trains violates the Commerce Clause because } \\
\text { loading and unloading is part of interstate transportation and } \\
\text { the tax is not apportioned. Dissent } 1 \text { (Black), without opinion. } \\
\text { Dissent } 2 \text { (Douglas with Rutledge) finds the tax does not } \\
\text { impede interstate commerce but might violate the Import- } \\
\text { Export Clause. Dissent } 3 \text { (Murphy) joins dissent } 2 \text { but not its } \\
\text { last part and would approve the tax. }\end{array}$ & $\begin{array}{l}\text { T a } \quad \mathrm{x} \\
\text { conservative }\end{array}$ \\
\hline $\begin{array}{l}\text { Bruce's Juices, Inc. } \\
\text { v. American Can } \\
\text { Co., } 330 \text { U.S. } 743 \\
(1947) .\end{array}$ & $\begin{array}{l}\text { Rejecting antitrust claim that quantity discounts (given to } \\
\text { larger customers) were illegal; "it does not follow that } \\
\text { Congress would forbid the savings of large-scale mass } \\
\text { production to be passed along to consumers." Dissent (Murphy } \\
\text { with all), "the unmistakable effect of the Court's decision is to } \\
\text { permit the recovery of discriminatory prices despite the plain } \\
\text { language and policy of the Act and despite the lessening of } \\
\text { competition that might thereby result." }\end{array}$ & $\begin{array}{l}\text { A n t it rust, } \\
\text { conservative }\end{array}$ \\
\hline
\end{tabular}




\begin{tabular}{|c|c|c|}
\hline $\begin{array}{l}\text { Order of United } \\
\text { C o m m e r c i a } 1 \\
\text { Travelers v. Wolfe, } \\
331 \text { U.S. } \quad 586 \\
(1947) \text {. }\end{array}$ & $\begin{array}{l}\text { Majority allows Ohio's respect for contractual limitations } \\
\text { period to govern the South Dakota contract and preclude } \\
\text { liability. Dissent (Black with all), "the Court today, in part, } \\
\text { nullifies a great purpose of the original Constitution, as later } \\
\text { expressed in the Tenth Amendment, to leave the several states } \\
\text { free to govern themselves in their domestic affairs. Hereafter, } \\
\text { if today's doctrine should be carried to its logical end, the state } \\
\text { in which the most powerful corporations are concentrated, or } \\
\text { those corporations themselves, might well be able to pass laws } \\
\text { which would govern contracts made by the people in all of the } \\
\text { other states." Liberal if about states' rights; conservative if } \\
\text { about contractual limitations. Treated as conservative. }\end{array}$ & $\begin{array}{l}\text { B u s i n e s s, } \\
\text { conservative }\end{array}$ \\
\hline $\begin{array}{l}\text { United States v. } \\
\text { Silk, } 331 \text { U.S. } 704 \\
(1947) .\end{array}$ & $\begin{array}{l}\text { For social security taxes, self-scheduling truckers with their } \\
\text { own trucks were independent contractors, coal loaders who had } \\
\text { their own tools were employees. Dissent } 1 \text { (Black with Douglas } \\
\text { and Murphy) would hold both to be employees without } \\
\text { opinion. Dissent } 2 \text { (Rutledge) would remand the truckers "not } \\
\text { think[ing] it necessary . . . to undertake drawing the final } \\
\text { conclusion generally in these borderline cases." }\end{array}$ & $\begin{array}{l}\text { T a } \quad \mathrm{x} \\
\text { conservative }\end{array}$ \\
\hline $\begin{array}{l}\text { Adam on } \\
\text { California, } \\
\text { U.S. } 46(1947) .\end{array}$ & $\begin{array}{l}\text { Federal right against self-incrimination does not apply to state } \\
\text { trials despite Fourteenth Amendment: "the due process clause } \\
\text { does not protect, by virtue of its mere existence the accused's } \\
\text { freedom from giving testimony by compulsion in state trials . } \\
\text {.." Dissent } 1 \text { (Murphy with Rutledge), the right against self- } \\
\text { incrimination "is a constituent part of the Fourteenth } \\
\text { Amendment." Dissent } 2 \text { (Black), the Fourteenth Amendment } \\
\text { intended and did apply the entire bill of rights to the states. }\end{array}$ & $\begin{array}{l}\text { C r i m P r o, } \\
\text { conservative }\end{array}$ \\
\hline $\begin{array}{l}\text { Foster v. Illinois, } \\
332 \text { U.S. } 134 \\
(1947) \text {. }\end{array}$ & $\begin{array}{l}\text { State defendants who plead guilty without counsel still } \\
\text { received due process. Dissent (Black with all), the Court } \\
\text { "waters down the Bill of Rights guarantee of counsel in } \\
\text { criminal cases." }\end{array}$ & $\begin{array}{l}\text { C r i m P r o, } \\
\text { conservative }\end{array}$ \\
\hline $\begin{array}{l}\text { Gayes v. New } \\
\text { York, } 332 \text { U.S. } 145 \\
(1947) .\end{array}$ & $\begin{array}{l}\text { Sixteen-year-old who plead guilty without counsel still } \\
\text { received due process. Dissent (Rutledge with all), "I am } \\
\text { unwilling to subscribe to such a doctrine of forfeitures } \\
\text { concerning constitutional rights, which in the extreme } \\
\text { circumstances of this case seems to me shocking." }\end{array}$ & $\begin{array}{l}\text { C r i m P r o, } \\
\text { conservative }\end{array}$ \\
\hline $\begin{array}{l}\text { Calda rola } \mathrm{v} . \\
\text { Eckert, } 332 \text { U.S. } \\
155 \text { (1947). }\end{array}$ & $\begin{array}{l}\text { Upholding no liability in NY courts to longshoreman injured } \\
\text { by defective vessel of the US managed by agent. Dissent } 1 \\
\text { (Douglas with Black and Murphy), "It is no answer to the legal } \\
\text { argument on which those private rights rest that the } \\
\text { Government might be inconvenienced if they were } \\
\text { recognized." Dissent } 2 \text { (Rutledge), "the liability here, since it } \\
\text { arises from a maritime tort, is a creature of federal law" and } \\
\text { would overrule the NY courts and impose liability. }\end{array}$ & $\begin{array}{l}\mathrm{T} \text { o } \mathrm{r} \text { t } \\
\text { conservative }\end{array}$ \\
\hline $\begin{array}{l}\text { Fay v. New York, } \\
332 \text { U.S. } 261 \\
(1947) .\end{array}$ & $\begin{array}{l}\text { NY special jury statute does not offend the Constitution. } \\
\text { Dissent (Murphy with all), the blue-ribbon jury selection in fact } \\
\text { excludes service workers and laborers, therefore it is not } \\
\text { representative and therefore violates the equal protection clause } \\
\text { of the Fourteenth Amendment. }\end{array}$ & $\begin{array}{l}\text { C r i m P r o, } \\
\text { conservative }\end{array}$ \\
\hline
\end{tabular}




\begin{tabular}{|c|c|c|}
\hline $\begin{array}{l}\text { M o r r i s v . } \\
\text { McComb, } 332 \text { U.S. } \\
422 \text { (1947). }\end{array}$ & $\begin{array}{l}\text { Transportation companies with } 3 \text { percent interstate work are } \\
\text { subject to the Interstate Commerce Commission and, due to an } \\
\text { exception in the statute, not subject to the FLSA overtime } \\
\text { rules. Dissent } 1 \text { (Murphy with Black and Douglas), "it is clear } \\
\text { that petitioner's truck drivers and mechanics are subject to the } \\
\text { wage and hour provisions of the Fair Labor Standards Act. } \\
\text { They spend virtually all of their time in transportation activities } \\
\text { which are an integral part of the production of goods for } \\
\text { interstate commerce." Dissent } 2 \text { (Rutledge), the court extends } \\
\text { an exception beyond its intended purpose. }\end{array}$ & $\begin{array}{l}\mathrm{L} \text { a b o r , } \\
\text { conservative }\end{array}$ \\
\hline $\begin{array}{l}\text { Cox v. United } \\
\text { States, } 332 \text { U.S. } \\
442 \text { (1947). }\end{array}$ & $\begin{array}{l}\text { Affirming AWOL conviction of Jehovah's Witnesses who } \\
\text { sought minister exemption from military service. Dissent } 1 \\
\text { (Douglas with Black), "The Selective Service files of these } \\
\text { petitioners establish, I think, their status as ministers of that } \\
\text { sect." Dissent } 2 \text { (Murphy with Rutledge), "I object to the } \\
\text { standard of review whereby the draft board classification is to } \\
\text { be sustained unless there is no evidence to support it." }\end{array}$ & $\begin{array}{l}\mathrm{S} \text { o c i a } 1, \\
\text { conservative }\end{array}$ \\
\hline $\begin{array}{l}\text { C a } 11 \text { e } \mathrm{n} \quad \mathrm{v} . \\
\text { Pennsylvania R.R. } \\
\text { Co., } 332 \text { U.S. } 625 \\
(1948) .\end{array}$ & $\begin{array}{l}\text { Affirming validity of settlement of worker with railroad and } \\
\text { refusing to impose burden of proof on railroad. Dissent (all } \\
\text { without opinion), the admiralty rule on releases should apply, } \\
\text { burden on carrier. }\end{array}$ & $\begin{array}{l}\mathrm{L} \text { a b o r , } \\
\text { conservative }\end{array}$ \\
\hline $\begin{array}{l}\text { Moore v. New } \\
\text { York, } 333 \text { U.S. } 565 \\
\text { (1948). }\end{array}$ & $\begin{array}{l}\text { NY 'blue ribbon' jury selected from panel that had no African } \\
\text { Americans or women was appropriate. Dissent (Murphy with } \\
\text { all), "Two men must forfeit their lives after having been } \\
\text { convicted of murder not by a jury of their peers, not by a jury } \\
\text { chosen from a fair cross-section of the community, but by a } \\
\text { jury drawn from a special group of individuals singled out in } \\
\text { a manner inconsistent with the democratic ideals of the jury } \\
\text { system." }\end{array}$ & $\begin{array}{l}\mathrm{C} \mathrm{r} \mathrm{i} \mathrm{m} \mathrm{P} \mathrm{r} \mathrm{o,} \\
\text { conservative }\end{array}$ \\
\hline $\begin{array}{l}\text { Bute v. Illinois, } \\
333 \text { U.S. } 640 \\
(1948) .\end{array}$ & $\begin{array}{l}\text { Upholding uncounseled conviction, "[t]he Fourteenth } \\
\text { Amendment, however, does not say that no state shall deprive } \\
\text { any person of liberty without following the federal process." } \\
\text { Dissent (Douglas with all), "Of what value is the constitutional } \\
\text { guaranty of a fair trial if an accused does not have counsel to } \\
\text { advise and defend him?" }\end{array}$ & $\begin{array}{l}\mathrm{C} \text { r i m P r o, } \\
\text { conservative }\end{array}$ \\
\hline $\begin{array}{l}\text { United States v. } \\
\text { South Buffalo Ry. } \\
\text { Co., } 333 \text { U.S. } 771 \\
(1948) .\end{array}$ & $\begin{array}{l}\text { Confirming interpretation of Interstate Commerce Act that } \\
\text { allows railroads to circumvent a prohibition by carrying items } \\
\text { belonging to affiliates. Dissent (Rutledge with all), "This is } \\
\text { another case where the Court saddles Congress with the load } \\
\text { of correcting its own emasculation of a statute, by drawing } \\
\text { from Congress' failure explicitly to overrule it, the unjustified } \\
\text { inference that Congress approves the mistake." }\end{array}$ & $\begin{array}{l}\text { B u s i n e s s, } \\
\text { conservative }\end{array}$ \\
\hline $\begin{array}{l}\text { B r i g g s } \mathrm{v} \text {. } \\
\text { Pennsylvania R.R. } \\
\text { Co., } 334 \text { U.S. } 304 \\
\text { (1948). }\end{array}$ & $\begin{array}{l}\text { Plaintiff recovering under the Federal Employers Liability Act } \\
\text { is not entitled to interest during appeal. Dissent (Rutledge with } \\
\text { all), "Nothing in [the statutory section's] terms permits an } \\
\text { implication that the award of interest is to be made as a matter } \\
\text { of judicial discretion. The language is mandatory." }\end{array}$ & $\begin{array}{l}\mathrm{L} \text { a } \mathrm{b} \text { o } \mathrm{r}, \\
\text { conservative }\end{array}$ \\
\hline
\end{tabular}




\begin{tabular}{|c|c|c|}
\hline $\begin{array}{l}\text { United States v. } \\
\text { Columbia Steel } \\
\text { Co., } 334 \text { U.S. } 495 \\
\text { (1948). }\end{array}$ & $\begin{array}{l}\text { Not enjoining acquisition by US Steel on antitrust grounds. } \\
\text { Dissent (Douglas with all), "The least I can say is that a } \\
\text { company that has that tremendous leverage on our economy is } \\
\text { big enough." }\end{array}$ & $\begin{array}{l}\text { B u s i n e s s, } \\
\text { conservative }\end{array}$ \\
\hline $\begin{array}{l}\text { Gryger v. } \text { Burke } \\
334 \text { U.S. } 728 \\
(1948) \text {. }\end{array}$ & $\begin{array}{l}\text { Uncounseled conviction not problematic, "It rather overstrains } \\
\text { our credulity to believe that one who had been a defendant } \\
\text { eight times and for whom counsel had twice waged defenses, } \\
\text { albeit unsuccessful ones, did not know of his right to engage } \\
\text { counsel." Dissent (Rutledge with all), "Counsel might not have } \\
\text { changed the sentence, but he could have taken steps to see that } \\
\text { the sentence was not predicated on misconception or } \\
\text { misreading of the controlling statute, a requirement of fair play } \\
\text { which absence of counsel withheld from this prisoner." }\end{array}$ & $\begin{array}{l}\text { C r i m P r o, } \\
\text { conservative }\end{array}$ \\
\hline $\begin{array}{l}\text { L u d e c k e v. } \\
\text { Watkins, } 335 \text { U.S. } \\
160 \text { (1948). }\end{array}$ & $\begin{array}{l}\text { "The very nature of the President's power to order the removal } \\
\text { of all enemy aliens rejects the notion that courts may pass } \\
\text { judgment upon the exercise of his discretion." Dissent } 1 \text { (Black } \\
\text { with all), "no act of Congress ... lends the slightest basis to the } \\
\text { claim that after hostilities with a foreign country have ended } \\
\text { the President or the Attorney General, one or both, can deport } \\
\text { aliens without a fair hearing reviewable in the courts."; Dissent } \\
2 \text { (Douglas with Murphy and Rutledge), "The notion that the } \\
\text { discretion of any officer of government can override due } \\
\text { process is foreign to our system." }\end{array}$ & $\begin{array}{l}\mathrm{I} \mathrm{m} \mathrm{m} \mathrm{i} \mathrm{g} \mathrm{r} \text {, } \\
\text { conservative }\end{array}$ \\
\hline $\begin{array}{l}\text { Comstock v. Group } \\
\text { of Institutional } \\
\text { Inv'rs, } 335 \text { U.S. } \\
211(1948) .\end{array}$ & $\begin{array}{l}\text { Reorganization: Refusing to disallow or subordinate parent } \\
\text { railroad claim against subsidiary for advances. Dissent } \\
\text { (Murphy with all), the subsidiary should not have been paying } \\
\text { dividends; "If there is mismanagement and if there is undue } \\
\text { harm to the creditors and preferred stockholders of the } \\
\text { subsidiary, the Deep Rock doctrine dictates subordination of } \\
\text { the parent's claim." }\end{array}$ & $\begin{array}{l}\text { B u s i n e s s, } \\
\text { conservative }\end{array}$ \\
\hline $\begin{array}{l}\text { Eckenrode v. } \\
\text { Pennsylvania R.R. } \\
\text { Co., } 335 \text { U.S. } 329 \\
\text { (1948). }\end{array}$ & $\begin{array}{l}\text { Affirming denial of negligence claim for employee. Dissent } \\
\text { (Black with all, neither majority nor dissent wrote opinions). }\end{array}$ & $\begin{array}{l}\text { L a b o r , } \\
\text { conservative }\end{array}$ \\
\hline $\begin{array}{l}\text { Grand River Dam } \\
\text { Auth. v. Grand- } \\
\text { Hydro, } 335 \text { U.S. } \\
359 \text { (1948). }\end{array}$ & $\begin{array}{l}\text { Where utility planning hydroelectric dam transferred the site to } \\
\text { state regulating entity pending evaluation for expropriation, the } \\
\text { use of the site for a dam was appropriate in its valuation. } \\
\text { Dissent (Douglas with all), "The result of this decision, no } \\
\text { matter how it is rationalized, is to give the water-power value } \\
\text { of the current of a river to a private party who by reason of } \\
\text { federal law neither has nor can acquire any lawful claim to it." }\end{array}$ & $\begin{array}{l}\text { B u s i n e s s, } \\
\text { conservative }\end{array}$ \\
\hline $\begin{array}{l}\text { Kovacs v. Cooper, } \\
\text { 336 U.S. } 77 \text { (1949). }\end{array}$ & $\begin{array}{l}\text { Finding local ordinance against amplified noise not to violate } \\
\text { freedom of speech. Dissent } 1 \text { (Murphy) without opinion. } \\
\text { Dissent } 2 \text { (Black with Douglas and Rutledge), should have } \\
\text { followed Saia and granted speech protection. }\end{array}$ & $\begin{array}{l}\mathrm{S} p \mathrm{p} \text { e } \mathrm{c} \mathrm{h} \\
\text { conservative }\end{array}$ \\
\hline
\end{tabular}




\begin{tabular}{|c|c|c|}
\hline $\begin{array}{l}\text { Fisher v. Pace, } 336 \\
\text { U.S. } 155 \text { (1949). }\end{array}$ & $\begin{array}{l}\text { Affirming conviction of lawyer for contempt. Dissent } 1 \\
\text { (Douglas with Black), "This lawyer was the victim of the pique } \\
\text { and hotheadedness of a judicial officer . . ." Dissent } 2 \\
\text { (Murphy), "the assumption that the judge is wise and impartial, } \\
\text { should make us quick to upset his determinations in the few } \\
\text { cases which clearly demonstrate light regard for the principles } \\
\text { that should guide a responsible jurist." Dissent } 3 \text { (Rutledge), } \\
\text { "there can be no due process in trial in the absence of calm } \\
\text { judgment and action, untinged with anger, from the bench." }\end{array}$ & $\begin{array}{l}\mathrm{C} \text { i } \mathrm{v} \mathrm{P} \mathrm{r} o \\
\text { conservative }\end{array}$ \\
\hline $\begin{array}{l}\text { Rey no lds v . } \\
\text { Atlantic Coast Line } \\
\text { R.R. Co., } 336 \text { U.S. } \\
207 \text { (1949). }\end{array}$ & $\begin{array}{l}\text { Affirming lack of employer liability without opinion; dissent } \\
\text { without opinion. }\end{array}$ & $\begin{array}{l}\mathrm{L} \text { a b o r , } \\
\text { conservative }\end{array}$ \\
\hline $\begin{array}{l}\text { Internationa } 1 \\
\text { Union, U.A.W., } \\
\text { A.F. of L., Local } \\
232 \text { v. Wisconsin } \\
\text { Emp't Relations } \\
\text { Bd., } 336 \text { U.S. } 245 \\
(1949) \text {. }\end{array}$ & $\begin{array}{l}\text { State's police power may prohibit intermittent work stoppages } \\
\text { (rather than a strike). Dissent (Murphy with Rutledge), "the } \\
\text { Court, by its reasoning and its quotation from a Congressional } \\
\text { report, now makes intermittent work stoppages the equivalent } \\
\text { of mutiny." Dissent } 2 \text { (Douglas with Black and Rutledge), "The } \\
\text { concerted activities in these cases were as old as labor's } \\
\text { struggle for existence and were aimed at . . . the purposes } \\
\text { which . . . the federal Act was designed to protect. Therefore } \\
\text { the legality of the methods used is exclusively a question of } \\
\text { federal law." }\end{array}$ & $\begin{array}{l}\mathrm{L} \text { a } \mathrm{b} \text { o } \mathrm{r}, \\
\text { conservative }\end{array}$ \\
\hline $\begin{array}{l}\text { Farrell v. United } \\
\text { States, } 336 \text { U.S. } \\
511(1949) .\end{array}$ & $\begin{array}{l}\text { Recognizing admiralty law obligation to maintain forever } \\
\text { seaman maimed in defense of vessel, but principle not } \\
\text { applicable to accident a mile from the ship at a different dock } \\
\text { later than time of allowed return. Dissent (Douglas with all), } \\
\text { "an injury received on returning to a ship from shore leave is } \\
\text { plainly incurred in the service" and therefore should receive } \\
\text { maintenance for life. }\end{array}$ & $\begin{array}{l}\mathrm{L} \text { a b o r , } \\
\text { conservative }\end{array}$ \\
\hline $\begin{array}{l}\text { Hynes v. Grimes } \\
\text { Packing Co., } 337 \\
\text { U.S. } 86 \text { (1949). }\end{array}$ & $\begin{array}{l}\text { Dissent would grant Native American tribe more rights against } \\
\text { outside fishermen. }\end{array}$ & $\begin{array}{l}\mathrm{T} \text { r i b a } 1 \\
\text { conservative }\end{array}$ \\
\hline $\begin{array}{l}\text { Cosmopolitan } \\
\text { Shipping Co. } \\
\text { McAllister, } \\
\text { U.S. } 783 \text { (1949). }\end{array}$ & $\begin{array}{l}\text { Injured seaman was only employee of the United States, not } \\
\text { the shipping agent, hence had no claim against agent. Dissent } \\
\text { (Black with all), without opinion. }\end{array}$ & $\begin{array}{l}\mathrm{L} \text { a } \mathrm{b} \text { o } \mathrm{r}, \\
\text { conservative }\end{array}$ \\
\hline $\begin{array}{l}\text { W e a d e v } \\
\text { Dichmann, Wright } \\
\text { \& Pugh, Inc., } 337 \\
\text { U.S. } 801 \text { (1949). }\end{array}$ & $\begin{array}{l}\text { Agent managing ship for the United States could only be liable } \\
\text { for his own negligence, not as owner. Dissent without opinion. }\end{array}$ & $\begin{array}{l}\mathrm{T} \quad \mathrm{o} \quad \mathrm{r} \quad \mathrm{t} \\
\text { conservative }\end{array}$ \\
\hline $\begin{array}{l}\text { Fink v. Shepard } \\
\text { S.S. Co., } 337 \text { U.S. } \\
810(1949) \text {. }\end{array}$ & $\begin{array}{l}\text { Shipping agent (for the United States) not liable to seaman for } \\
\text { accident. Dissent without opinion. }\end{array}$ & $\begin{array}{l}\mathrm{L} \text { a } \mathrm{b} \text { o } \mathrm{r}, \\
\text { conservative }\end{array}$ \\
\hline
\end{tabular}




\section{VINSON-BLACK-DOUGLAS-MURPHY-RUTLEDGE (EIGHT O'CLOCK)}

\begin{tabular}{|c|c|c|}
\hline $\begin{array}{l}\text { Edward Katzinger } \\
\text { Co. v. Chicago } \\
\text { Metallic Mfg. } \\
\text { Co., } 329 \text { U.S. } 394 \\
\text { (1946). }\end{array}$ & $\begin{array}{l}\text { Clause in patent license establishing price-fixing upon the } \\
\text { licensee renders license invalid. Dissent (Frankfurter with all, } \\
\text { in McGregor v. Westinghouse, } 329 \text { U.S. } 402,1947 \text { ) licensee of } \\
\text { patent may not challenge its validity, the court "use[s] the } \\
\text { excuse of an inoperative price-fixing clause to allow a licensee } \\
\text { to escape his otherwise valid promise to pay royalties." }\end{array}$ & Antitrust, liberal \\
\hline $\begin{array}{l}\text { MacGregor v. } \\
\text { Westinghouse Elec. } \\
\& \text { Mfg. Co., } 329 \\
\text { U.S. } 402 \text { (1947). }\end{array}$ & (Same as Edward Katzinger Co., 329 U.S. 394.) & Antitrust, liberal \\
\hline $\begin{array}{l}\text { Saia v. New York, } \\
334 \text { U.S. } 558 \\
(1948) .\end{array}$ & $\begin{array}{l}\text { Free speech; reversing conviction of violation of municipal } \\
\text { ordinance prohibiting use of sound amplification in public. } \\
\text { Dissent } 1 \text { (Frankfurter with Reed and Burton) "Surely there is } \\
\text { not a constitutional right to force unwilling people to listen." } \\
\text { Dissent } 2 \text { (Jackson) "It is astonishing news to me if the } \\
\text { Constitution prohibits a municipality from policing, controlling } \\
\text { or forbidding erection of [sound amplification] equipment by } \\
\text { a private party in a public park." In effect reversed by Ward v. } \\
\text { Rock Against Racism, } 491 \text { U.S. } 781 \text { (1989) (allowing NYC to } \\
\text { impose use of its own sound amplification equipment and } \\
\text { technicians without citing Saia; also in tension with Kovacs, } \\
336 \text { U.S. } 77 \text {, same Vinson composition, different majority). }\end{array}$ & Speech, liberal \\
\hline $\begin{array}{l}\text { Urie v. Thompson, } \\
337 \text { U.S. } 163 \\
(1949) .\end{array}$ & $\begin{array}{l}\text { Upholding liability of railroad to driver for silicosis from long- } \\
\text { term inhalation under Boiler Inspection Act. Dissent } 1 \\
\text { (Frankfurter with Reed, Jackson and Burton) would remand but } \\
\text { not construe BIA as protecting from occupational diseases and } \\
\text { limit recovery to Federal Employers Liability Act. }\end{array}$ & Labor, liberal \\
\hline
\end{tabular}


Appendix B2: Tables of Stewart Composition Majorities Producing More than Two 5-4 Opinions

We list the opinions of the United States Supreme Court while its composition is defined by its junior justice being Stewart. The Stewart composition consists of four appointees of Democratic presidents (Black, Clark, Douglas, and Frankfurter) and five appointees of Republican presidents (Brennan, Harlan, Stewart, Warren, and Whittaker). We list the majorities as they appear in the corresponding figure in the full-text proceeding clockwise from the nine o'clock position. The name of the case, along with the citation to the United States Reporter, and the year appears in the first column. The second column holds our brief description of the outcome compared to the dissent's position. The third column holds the legal field and the political slant of the majority's position as it arises by juxtaposition to that of the minority. We sort the justices in the majorities by, first, the chief justice, then the associate justices by alphabetical order.

\section{WARREN-BLACK-BRENNAN-CLARK-DOUGLAS (NINE O'CLOCK)}

\begin{tabular}{|c|c|c|}
\hline $\begin{array}{l}\text { Monrosa v. } \\
\text { Carbon Black } \\
\text { Exp., Inc., } 359 \\
\text { U.S. } 180 \text { (1959). }\end{array}$ & $\begin{array}{l}\text { Interpreting bill of lading setting Genoa as forum to only apply } \\
\text { to in personam actions; dissent (Harlan with all), "I cannot } \\
\text { agree..." }\end{array}$ & Business, liberal \\
\hline $\begin{array}{l}\text { Farmers Educ. \& } \\
\text { Coop. Union of } \\
\text { Am., N. Dakota } \\
\text { Div., v. WDAY, } \\
\text { Inc., } 360 \text { U.S. } 525 \\
(1959) .\end{array}$ & $\begin{array}{l}\text { Broadcaster of political speech is immune from libel. Dissent } \\
\text { (Frankfurter with all) says federal act does not prevent liability } \\
\text { for libel under proper state statutes. }\end{array}$ & Speech, liberal \\
\hline $\begin{array}{l}\text { McElroy v. United } \\
\text { States, } 361 \text { U.S. } \\
281(1960) .\end{array}$ & $\begin{array}{l}\text { Courts martial do not have jurisdiction over non-military } \\
\text { employees of the military abroad. Dissent } 1 \text { (Harlan with } \\
\text { Frankfurter at } 361 \text { U.S. 234) considers the result "a much too } \\
\text { narrow conception of the constitutional power of Congress." } \\
\text { Dissent } 2 \text { (Whittaker with Stewart), no jurisdiction over } \\
\text { dependents of military personnel but yes over employees. }\end{array}$ & CrimPro, liberal \\
\hline $\begin{array}{l}\text { Goett v. Union } \\
\text { Carbide Corp., } 361 \\
\text { U.S. } 340(1960) \text {. }\end{array}$ & $\begin{array}{l}\text { Vacating appellate decision of no liability for barge accident } \\
\text { remand to establish if state or admiralty law applied. Dissent } 1 \\
\text { (Harlan with Frankfurter) Ct of App applied the law correctly. } \\
\text { Dissent } 2 \text { (Whittaker), "persuaded that the Court of Appeals } \\
\text { has made sufficiently clear that it thought this diversity, } \\
\text { admiralty, death case was governed by the general maritime } \\
\text { law, as remedially supplemented by the West Virginia } \\
\text { Wrongful Death statute, and properly decided it on that basis." } \\
\text { Dissent } 3 \text { (Stewart), "even if the Court of Appeals mistakenly } \\
\text { applied substantive standards of federal maritime law, no } \\
\text { purpose could be served by remanding this case unless it were } \\
\text { shown that the state law is somehow more favorable to the } \\
\text { petitioner. But there has been no [such] showing-nor any } \\
\text { suggestion..." }\end{array}$ & $\begin{array}{l}\text { Labor/Tort, } \\
\text { liberal }\end{array}$ \\
\hline
\end{tabular}




\begin{tabular}{|c|c|c|}
\hline $\begin{array}{l}\text { Flora v. United } \\
\text { States, } 362 \text { U.S. } \\
145(1960) .\end{array}$ & $\begin{array}{l}\text { The statute "requires full payment of the assessment before an } \\
\text { income tax refund suit can be maintained in a Federal District } \\
\text { Court." Dissent (Whittaker with all) "cannot doubt that } \\
\text { Congress plainly expressed its intention to waive sovereign } \\
\text { immunity to suits, and to grant jurisdiction to District Courts } \\
\text { over suits, against the United States to recover 'any sum' } \\
\text { alleged to have been wrongfully collected." }\end{array}$ & Tax, liberal \\
\hline $\begin{array}{l}\text { Miller Music Corp. } \\
\text { v. Charles } \mathrm{N} . \\
\text { Daniels, Inc., } 362 \\
\text { U.S. } 373 \text { (1960). }\end{array}$ & $\begin{array}{l}\text { Executor of deceased has right to renew copyright. Dissent } \\
\text { (Harlan with all), "the effect of the decision is to enable an } \\
\text { author who has sold his renewal rights during his lifetime to } \\
\text { defeat the transaction by a deliberate subsequent bequest of } \\
\text { those rights to others in his will." }\end{array}$ & IP, liberal \\
\hline $\begin{array}{l}\text { United States } v . \\
\text { Republic Steel } \\
\text { Corp., } 362 \text { U.S. } \\
482(1960) .\end{array}$ & $\begin{array}{l}\text { Remanding on riverbed deepening. Dissent } 1 \text { (Frankfurter) } \\
\text { found the injunction statutorily precluded. Dissent } 2 \text { (Harlan } \\
\text { with rest), "In order to reach what it considers a just result the } \\
\text { Court, in the name of 'charitably' construing the Act, has felt } \\
\text { justified in reading into the statute things that actually are not } \\
\text { there." }\end{array}$ & Envir'l, liberal \\
\hline $\begin{array}{l}\text { FTC v. Henry } \\
\text { Broch \& Co., } 363 \\
\text { U.S. } 166(1960) .\end{array}$ & $\begin{array}{l}\text { Robinson-Patman Act prohibits volume discounts disguised as } \\
\text { brokerage fees. Dissent (Whittaker with all) believes the statute } \\
\text { allows volume discounts. }\end{array}$ & Antitrust, liberal \\
\hline $\begin{array}{l}\text { Sunray Mid- } \\
\text { Continent Oil Co. } \\
\text { v. Federal Power } \\
\text { Commission, } 364 \\
\text { U.S. } 137(1960) \text {. }\end{array}$ & $\begin{array}{l}\text { Federal Power Commission has the authority to force recipient } \\
\text { of license to have the license not expire. Dissent } 1 \text { (Harlan with } \\
\text { all), "I fear this is another instance where the Court has taken } \\
\text { impermissible liberties with statutory language in order to } \\
\text { remedy what it considers an undesirable deficiency in the way } \\
\text { Congress has written the statute." Dissent } 2 \text { (Frankfurter), "The } \\
\text { Commission cannot rest denial [of a license] on its ipse dixit. } \\
\text { Nor can the Commission rest on the general spirit or the } \\
\text { ultimate purposes of the Natural Gas Act, for to do so amounts } \\
\text { to saying that the Act forbids time certificates, when in fact it } \\
\text { does not." }\end{array}$ & Business, liberal \\
\hline $\begin{array}{l}\text { Sun Oil Co. v. } \\
\text { Federal Power } \\
\text { Commission, } 364 \\
\text { U.S. } 170(1960)\end{array}$ & (sister case to Sunray Mid-Continent Oil Co., 364 U.S. 137) & Business, liberal \\
\hline $\begin{array}{l}\text { Poller v. CBS, } 368 \\
\text { U.S. } 464 \text { (1962). }\end{array}$ & $\begin{array}{l}\text { Reverses SJ for defendants in antitrust. Dissent (Harlan with } \\
\text { all), "As I see it, this is one of those cases, not unfamiliar in } \\
\text { treble-damage litigation, where injury resulting from normal } \\
\text { business hazards is sought to be made redressable by casting } \\
\text { the affair in antitrust terms. I think that the antitrust laws do not } \\
\text { fit this case, and that the courts below were quite correct in } \\
\text { holding that the respondents were entitled to judgment as a } \\
\text { matter of law." }\end{array}$ & Antitrust, liberal \\
\hline
\end{tabular}




\section{WARREN-BLACK-BRENNAN-DOUGLAS-STEWART (TEN O-CLOCK)}

\begin{tabular}{|c|c|c|}
\hline $\begin{array}{l}\text { SEC v. Variable } \\
\text { Annuity Life } \\
\text { Insurance Co. of } \\
\text { America, } 359 \\
\text { U.S. } 65 \text { (1959). }\end{array}$ & $\begin{array}{l}\text { Variable annuity contracts (pegged on the performance of } \\
\text { portfolios) required registration with the Securities and } \\
\text { Exchange Commission as investment vehicles. Dissent (Harlan } \\
\text { with all), "We should decline to admit the SEC into this } \\
\text { traditionally state regulatory domain." }\end{array}$ & Business, liberal \\
\hline $\begin{array}{l}\text { Irvin v. Dowd, } 359 \\
\text { U.S. } 394 \text { (1959). }\end{array}$ & $\begin{array}{l}\text { Death penalty habeas case proper because state remedies were } \\
\text { effectively exhausted. Dissent } 1 \text { (Frankfurter) wrote that "it is } \\
\text { inconceivable that, on the proceeding before us, we would } \\
\text { entertain jurisdiction." Dissent } 2 \text { (Harlan with all) said Court } \\
\text { should decide the merits and not remand. }\end{array}$ & CrimPro, liberal \\
\hline $\begin{array}{l}\text { In re Sawyer, } 360 \\
\text { U.S. } 622(1959) .\end{array}$ & $\begin{array}{l}\text { Majority reverses lawyer's sanction; dissent (Frankfurter with } \\
\text { all), "when a lawyer goes before a public gathering and fiercely } \\
\text { charges that the trial in which he is a participant is unfair, that } \\
\text { the judge lacks integrity, the circumstances under which he } \\
\text { speaks not only sharpen what he says but he imparts to his } \\
\text { attack inflaming and warping significance. He says that the } \\
\text { very court-room into which he walks to plead his case is a } \\
\text { travesty, that the procedures and reviews established to protect } \\
\text { his client from such conduct are a sham. 'We are a society } \\
\text { governed by law, whose integrity it is the lawyer's special role } \\
\text { to guard and champion.' No matter how narrowly conceived } \\
\text { this role may be, it has been betrayed by a lawyer who has } \\
\text { engaged in the kind of conduct here found by the Hawaii court. } \\
\text { Certainly this Court, the supreme tribunal charged with } \\
\text { maintaining the rule of law, should be the last place in which } \\
\text { these attacks on the fairness and integrity of a judge and the } \\
\text { conduct of a trial should find constitutional sanction." }\end{array}$ & CivPro, liberal \\
\hline $\begin{array}{l}\text { Elkins v. } \text { United } \\
\text { States, } 364 \text { U.S. } \\
206(1960) .\end{array}$ & $\begin{array}{l}\text { Evidence seized by state agents which would be inadmissible } \\
\text { if seized by federal agents is inadmissible. Dissent } 1 \\
\text { (Frankfurter with all), "I would not embark upon a hazardous } \\
\text { jettisoning of a rule which has prevailed in the federal courts } \\
\text { for half a century without bringing to the surface demonstrated } \\
\text { evils . . . ." Dissent } 2 \text { (Harlan with Clark and Whittaker), "I } \\
\text { would retain intact the nonexclusionary rule of [past] cases, } \\
\text { which has behind it the strongest judicial credentials, the } \\
\text { sanction of long usage, and the support of what, in my opinion, } \\
\text { is sound constitutional doctrine...." }\end{array}$ & CrimPro, liberal \\
\hline $\begin{array}{l}\text { Rios v. United } \\
\text { States, } 364 \text { U.S. } \\
253(1960) .\end{array}$ & (sister case to Elkins, 364 U.S. 206) & CrimPro, liberal \\
\hline
\end{tabular}




\begin{tabular}{|c|c|c|}
\hline $\begin{array}{l}\text { Shelton v. Tucker, } \\
364 \text { U.S. } 479 \\
(1960) \text {. }\end{array}$ & $\begin{array}{l}\text { "[T] compel a teacher to disclose his every associational tie is } \\
\text { to impair that teacher's right of free association, a right closely } \\
\text { allied to freedom of speech and a right which, like free speech, } \\
\text { lies at the foundation of a free society." Dissent } 1 \text { (Frankfurter } \\
\text { with all), the statute "does not exceed the permissible range of } \\
\text { state action limited by the Fourteenth Amendment." Dissent } 2 \\
\text { (Harlan with all), the "requirement cannot be said to transgress } \\
\text { the constitutional limits of a State's conceded authority to } \\
\text { determine the qualifications of those serving it as teachers ... } \\
. "\end{array}$ & Social, liberal \\
\hline $\begin{array}{l}\text { Campbell v. United } \\
\text { States, } 365 \text { U.S. } 85 \\
\text { (1961). }\end{array}$ & $\begin{array}{l}\text { Remanding to inquire about witness statement in possession of } \\
\text { FBI deliverable to the defense per statute. Dissent } 1 \\
\text { (Frankfurter with all), "It is not for the court to question that } \\
\text { the foundation for production-here, the existence of a } \\
\text { document - is wanting, if counsel for defendants do not } \\
\text { question the Government's explanation for non-production." }\end{array}$ & CrimPro, liberal \\
\hline $\begin{array}{l}\text { Milanovich v. } \\
\text { United States, } 365 \\
\text { U.S. } 551 \text { (1961). }\end{array}$ & $\begin{array}{l}\text { Remanding for correct instruction to jury to convict of either } \\
\text { lesser included or greater offense. Dissent } 1 \text { (Frankfurter with } \\
\text { all), "the doctrine that an aider and abettor to a theft who at an } \\
\text { appreciably later time receives some of the stolen goods may } \\
\text { not be charged on separate counts for both transactions, or that } \\
\text { a judge may not leave both counts for a jury verdict of guilt on } \\
\text { either one or both, ... is to disregard the whole philosophy of } \\
\text { our law based on precedents." Dissent } 2 \text { (Clark with } \\
\text { Whittaker), "How, I ask, could [the defendant] have been } \\
\text { harmed by the jury finding her guilty of both offenses rather } \\
\text { than choosing between the two?" }\end{array}$ & CrimPro, liberal \\
\hline $\begin{array}{l}\text { Stewart v. United } \\
\text { States, } 366 \text { U.S. } 1 \\
\text { (1961). }\end{array}$ & $\begin{array}{l}\text { Mention of not having testified in prior trials reversible error. } \\
\text { Dissent } 1 \text { (Clark with Whittaker), the court "effectively } \\
\text { remove[s] from our law the concept of harmless error in capital } \\
\text { cases." Dissent } 2 \text { (Frankfurter with Harlan and Whittaker), to } \\
\text { assume "that the jury was influenced by the two questions on } \\
\text { which the verdict is reversed here, is to show less respect for } \\
\text { the jury system than do the opponents of the system." }\end{array}$ & CrimPro, liberal \\
\hline $\begin{array}{l}\text { Deutch v. } \text { United } \\
\text { States, } 367 \text { U.S. } \\
456(1961) .\end{array}$ & $\begin{array}{l}\text { Reversing conviction for refusal to identify other communists } \\
\text { to the House Committee on Un-American Activities for lack of } \\
\text { pertinency of the questions. Dissent } 1 \text { (Harlan with } \\
\text { Frankfurter), "the defendant made no 'pertinency' objection . } \\
\text {. [therefore] the Government at trial is left free to satisfy the } \\
\text { requirement of pertinency in any way it may choose." Dissent } \\
2 \text { (Whittaker with Clark), "the questions... were, on their face, } \\
\text { clearly pertinent to the inquiry as a matter of law." }\end{array}$ & Social, liberal \\
\hline
\end{tabular}




\section{ClARK-FrANKFURTER-HARLAN-STEWART-WHITTAKER (THREE O'ClOCK)}

\begin{tabular}{|c|c|c|}
\hline $\begin{array}{l}\text { Romero v. } \\
\text { International } \\
\text { Terminal } \\
\text { Operating Co., } \\
358 \text { U.S. } 354 \\
(1959) \text {. }\end{array}$ & $\begin{array}{l}\text { U.S. courts do not have jurisdiction over claim of Spanish } \\
\text { seaman in Spanish vessel against foreign owner. Dissent } 1 \\
\text { (Brennan with all), jurisdiction over employer exists. Dissent } \\
2 \text { (Black), the words "any seaman" do not exclude foreigners. } \\
\text { Dissent } 3 \text { (Douglas), agreeing with Black. }\end{array}$ & $\begin{array}{l}\mathrm{C} \text { i } \mathrm{v} \mathrm{P} r \mathrm{o}, \\
\text { conservative }\end{array}$ \\
\hline $\begin{array}{l}\text { The Tungus v. } \\
\text { Skovgaard, } 358 \\
\text { U.S. } 588(1959) \text {. }\end{array}$ & $\begin{array}{l}\text { Affirming reversal of dismissal of suit for wrongful death } \\
\text { aboard ship. Dissent } 1 \text { (Brennan with all) does not believe the } \\
\text { state wrongful death statute encompasses maritime torts and } \\
\text { concurs. Concurrence (Frankfurter), "in situations like the } \\
\text { present the construction of state law should not, as a matter of } \\
\text { the wise administration of law, be made independently by the } \\
\text { lower federal courts, but its authoritative construction should } \\
\text { be sought, under readily available state procedure, from the } \\
\text { state court, while the case is held in the federal court." }\end{array}$ & $\begin{array}{l}\mathrm{C} \text { i v P r o, } \\
\text { conservative }\end{array}$ \\
\hline $\begin{array}{l}\text { United N.Y and } \\
\text { N.J. Sandy Hook } \\
\text { Pilots Ass'n v. } \\
\text { Halecki, } 358 \text { U.S. } \\
613 \text { (1959). }\end{array}$ & $\begin{array}{l}\text { Reversing liability to repairman from on-board accident } \\
\text { because seaworthiness was not owed to him. Dissent (Brennan } \\
\text { with all), he was owed seaworthiness. Concurrence } \\
\text { (Frankfurter), same as in The Tungus, } 358 \text { U.S. } 588 \text {. }\end{array}$ & $\begin{array}{l}\mathrm{T} \quad \mathrm{o} \quad \mathrm{r} \quad \mathrm{t}, \\
\text { conservative }\end{array}$ \\
\hline $\begin{array}{l}\text { Brown v. United } \\
\text { States, } 359 \text { U.S. } 41 \\
(1959) .\end{array}$ & $\begin{array}{l}\text { Affirming summary contempt punishment. Dissent } 1 \text { (Warren } \\
\text { with all), the majority "sanctions the procedure used below to } \\
\text { convict petitioner summarily ... to } 15 \text { months' . . under Rule } \\
42 \text { (a) when [it] should have been [under] Rule } 42 \text { (b). The } \\
\text { denial of even the minimal protections accorded by Rule } 42 \text { (b) } \\
\text { deprived petitioner of an opportunity to prepare a legal defense, } \\
\text { or to demonstrate extenuating circumstances ...." }\end{array}$ & $\begin{array}{l}\text { C r i m P r o, } \\
\text { conservative }\end{array}$ \\
\hline $\begin{array}{l}\text { Bartkus v. Illinois, } \\
359 \text { U.S. } 121 \\
(1959) .\end{array}$ & $\begin{array}{l}\text { Trial under Illinois law for bank robbery after federal acquittal } \\
\text { did not violate due process. Dissent } 1 \text { (Black with Warren and } \\
\text { Douglas), "double prosecutions for the same offense are ... } \\
\text { contrary to the spirit of our free country . . . Dissent } 2 \\
\text { (Brennan with Warren and Douglas), "the extent of } \\
\text { participation of the federal authorities here constituted this state } \\
\text { prosecution actually a second federal prosecution...." }\end{array}$ & $\begin{array}{l}\mathrm{C} \mathrm{r} \mathrm{i} \mathrm{m} \mathrm{P} \mathrm{r} \mathrm{o,} \\
\text { conservative }\end{array}$ \\
\hline $\begin{array}{l}\text { Frank v. Maryland, } \\
359 \text { U.S. } 360 \\
(1959) .\end{array}$ & $\begin{array}{l}\text { Upholding search and conviction for health inspection of } \\
\text { defendant who had half-ton pile of rat feces and hay in back } \\
\text { yard. Dissent (Douglas with all), city inspector needed proper } \\
\text { warrant. }\end{array}$ & $\begin{array}{l}\text { C r i m P r o, } \\
\text { conservative }\end{array}$ \\
\hline $\begin{array}{l}\text { Uphaus v. Wyman, } \\
360 \text { U.S. } 72 \text { (1959). }\end{array}$ & $\begin{array}{l}\text { State had authority to investigate communist activity. Dissent } \\
\text { (Brennan with all), "This record, I think, not only fails to reveal } \\
\text { any interest of the State sufficient to subordinate appellant's } \\
\text { constitutionally protected rights, but affirmatively shows that } \\
\text { the investigatory objective was the impermissible one of } \\
\text { exposure for exposure's sake." }\end{array}$ & $\begin{array}{l}\mathrm{S} \text { o c i a } 1, \\
\text { conservative }\end{array}$ \\
\hline
\end{tabular}




\begin{tabular}{|c|c|c|}
\hline $\begin{array}{l}\text { Bare nblatt } v . \\
\text { United States, } 360 \\
\text { U.S. } 109(1959) .\end{array}$ & $\begin{array}{l}\text { Upholding contempt for refusing to answer questions of House } \\
\text { Un-American Activities Committee. Dissent } 1 \text { (Black with } \\
\text { Warren and Douglas), "Ultimately all the questions in this case } \\
\text { really boil down to one-whether we as a people will try } \\
\text { fearfully and futilely to preserve democracy by adopting } \\
\text { totalitarian methods, or whether in accordance with our } \\
\text { traditions and our Constitution we will have the confidence and } \\
\text { courage to be free." Dissent } 2 \text { (Brennan) agrees; First } \\
\text { Amendment should have prevailed. }\end{array}$ & $\begin{array}{l}\text { S o c i a } 1 \text {, } \\
\text { conservative }\end{array}$ \\
\hline $\begin{array}{l}\text { Anonymous v. } \\
\text { Baker, } 360 \text { U.S. } \\
287(1959) .\end{array}$ & $\begin{array}{l}\text { State judicial inquiry could properly question investigators } \\
\text { accused of ambulance chasing without counsel present. Dissent } \\
\text { (Black with all), "In upholding such secret inquisitions the } \\
\text { Court once again retreats from what I conceive to be its highest } \\
\text { duty, that of maintaining unimpaired the rights and liberties } \\
\text { guaranteed by the Fourteenth Amendment and the Bill of } \\
\text { Rights." }\end{array}$ & $\begin{array}{l}\mathrm{C} \text { i } \mathrm{v} \mathrm{P} \mathrm{r} \text { o, } \\
\text { conservative }\end{array}$ \\
\hline $\begin{array}{l}\text { Rosenberg v. } \\
\text { United States, } 360 \\
\text { U.S. } 367(1959) \text {. }\end{array}$ & $\begin{array}{l}\text { Error in non-production of evidence was harmless. Dissent } \\
\text { (Brennan with all), "it is impossible for a judge to be fully } \\
\text { aware of all the possibilities for impeachment inhering in a } \\
\text { prior statement of a government witness, 'Because only the } \\
\text { defense [can.']" }\end{array}$ & $\begin{array}{l}\text { C r i m P r o, } \\
\text { conservative }\end{array}$ \\
\hline $\begin{array}{l}\text { Pittsburgh Plate } \\
\text { Glass Co. v. United } \\
\text { States, } 360 \text { U.S. } \\
395 \text { (1959). }\end{array}$ & $\begin{array}{l}\text { Defense not entitled to grand jury minutes. Dissent (Brennan } \\
\text { with all), "Plainly defense counsel were not asking to see the } \\
\text { minutes of the entire grand jury proceedings, nor even of all of } \\
\text { Jonas' testimony before the grand jury unless all of it was on } \\
\text { the same subject matter as his trial testimony." }\end{array}$ & $\begin{array}{l}\mathrm{C} \mathrm{r} \text { i m P r o, } \\
\text { conservative }\end{array}$ \\
\hline $\begin{array}{l}\text { Inman v. Baltimore } \\
\text { \& Ohio R.R. Co., } \\
361 \quad \text { U.S. } 138 \\
(1959) .\end{array}$ & $\begin{array}{l}\text { Railroad whose longtime signalman at crossing was hit by } \\
\text { drunk driver was entitled to avoid liability for lack of any } \\
\text { negligence. Dissent (Douglas with all), "certainly the duty to } \\
\text { make a reasonable effort to provide a safe place of work is not } \\
\text { conditioned upon an employee's first being injured or killed." }\end{array}$ & $\begin{array}{l}\mathrm{T} \quad \mathrm{o} \quad \mathrm{r} \quad \mathrm{t} \\
\text { conservative }\end{array}$ \\
\hline $\begin{array}{l}\text { Abel v. United } \\
\text { States, } 362 \text { U.S. } \\
217(1960) .\end{array}$ & $\begin{array}{l}\text { Dissents } 1 \text { (Douglas with Black) and } 2 \text { (Brennan with all) } \\
\text { would find search violative of Fourth Amendment. }\end{array}$ & $\begin{array}{l}\text { C r i m P r o } \\
\text { conservative }\end{array}$ \\
\hline $\begin{array}{l}\text { Mitchell v. H. B. } \\
\text { Zachry Co., } 362 \\
\text { U.S. } 310(1960) .\end{array}$ & $\begin{array}{l}\text { Builder of municipal dam not sufficiently closely related to } \\
\text { commerce for the Fair Labor Standards Act to apply to } \\
\text { employees. Dissent (Douglas with all) disagreeing. }\end{array}$ & $\begin{array}{l}\mathrm{L} \text { a } \mathrm{b} \text { o } \mathrm{r} \text {, } \\
\text { conservative }\end{array}$ \\
\hline $\begin{array}{l}\text { Niukkanen } \quad \mathrm{v} . \\
\text { McAlexander, } 362 \\
\text { U.S. } 390(1960) .\end{array}$ & $\begin{array}{l}\text { Deportation of alien as communist was proper (per curiam). } \\
\text { Dissent (Douglas with all), "The 'meaningful association' with } \\
\text { the Party . . . simply has not been established here." }\end{array}$ & $\begin{array}{l}\text { S o c i a } 1 \\
\text { conservative }\end{array}$ \\
\hline $\begin{array}{l}\text { Schaffer v. United } \\
\text { States, } 362 \text { U.S. } \\
511(1960) .\end{array}$ & $\begin{array}{l}\text { Joinder despite dismissal of conspiracy count was harmless } \\
\text { error. Dissent (Douglas with all), "There is no sure way to } \\
\text { protect against [guilt by association] except by separate trials, } \\
\text { especially where, as here, the several defendants, though } \\
\text { unconnected, commit the crimes charged by dealing with one } \\
\text { person...." }\end{array}$ & $\begin{array}{l}\text { C r i m P r o, } \\
\text { conservative }\end{array}$ \\
\hline $\begin{array}{l}\text { Parker v. Ellis, } 362 \\
\text { U.S. } 574 \text { (1960). }\end{array}$ & $\begin{array}{l}\text { Habeas petition moot after early release for good conduct. } \\
\text { Dissent (Douglas with all), "Justice demands that he be given } \\
\text { the relief he deserves." }\end{array}$ & $\begin{array}{l}\text { C r i m P r o, } \\
\text { conservative }\end{array}$ \\
\hline
\end{tabular}




\begin{tabular}{|c|c|c|}
\hline $\begin{array}{l}\text { Levine v. United } \\
\text { States, } 362 \text { U.S. } \\
610(1960) .\end{array}$ & $\begin{array}{l}\text { Contempt conviction in closed courtroom was proper, } \\
\text { defendant did not request open. Dissent } 1 \text { (Black with Warren } \\
\text { and Douglas), against precedent. Dissent } 2 \text { (Brennan with } \\
\text { Douglas), waiver of right to open trial should be express and } \\
\text { informed. }\end{array}$ & $\begin{array}{l}\text { C r i m P r o, } \\
\text { conservative }\end{array}$ \\
\hline $\begin{array}{l}\text { K i } \mathrm{m} \mathrm{m} \quad \mathrm{v} . \\
\text { Rosenberg, } 363 \\
\text { U.S. } 405(1960) .\end{array}$ & $\begin{array}{l}\text { Alien under deportation order had no right to self-deport, } \\
\text { government did not have burden to show membership in } \\
\text { communist party. Dissent (Douglas with all), "Today we allow } \\
\text { invocation of the Fifth Amendment ... as proof that an alien } \\
\text { lacks the 'good moral character' which he must have . . . to } \\
\text { become eligible for [self-deportation]." }\end{array}$ & $\begin{array}{l}\mathrm{S} \text { o c i a } 1, \\
\text { conservative }\end{array}$ \\
\hline $\begin{array}{l}\text { F1em ming v. } \\
\text { Nestor, } 363 \text { U.S. } \\
603 \text { (1960). }\end{array}$ & $\begin{array}{l}\text { Deportation grounds that terminate social security benefits are } \\
\text { proper. Dissent } 1 \text { (Black), constitutes punishment without due } \\
\text { process. Dissent } 2 \text { (Douglas), beyond Congressional authority. } \\
\text { Dissent } 3 \text { (Brennan with Warren \& Douglas), is ex post facto } \\
\text { punishment. }\end{array}$ & $\begin{array}{l}\mathrm{S} \text { o c i a } 1, \\
\text { conservative }\end{array}$ \\
\hline $\begin{array}{l}\text { Schilling v. Rogers, } \\
363 \text { U.S. } 666 \\
(1960) \text {. }\end{array}$ & $\begin{array}{l}\text { Courts cannot review administrative discretion of returning } \\
\text { property to enemy aliens. Dissent (Brennan with all), "We } \\
\text { retreat from established principles of administrative law when } \\
\text { we say [judicial review of administrative discretion] is } \\
\text { unavailable here." }\end{array}$ & $\begin{array}{l}\mathrm{C} \text { i v P r o, } \\
\text { conservative }\end{array}$ \\
\hline $\begin{array}{l}\text { Gonzales v. United } \\
\text { States, } 364 \text { U.S. } 59 \\
(1960) \text {. }\end{array}$ & $\begin{array}{l}\text { Conviction of Jehovah's Witnesses for refusing draft upheld. } \\
\text { Dissent (Warren with all), "I am unwilling to give to [this } \\
\text { deferential to religious objectors] statute . . . a construction } \\
\text { which results in a young man of unblemished reputation, who } \\
\text { claims religious scruples, being sent to prison for } 15 \text { months } \\
\text { without having received a full and fair consideration of his } \\
\text { case." }\end{array}$ & $\begin{array}{l}\mathrm{C} \text { i } \mathrm{v} \mathrm{P} \mathrm{r} \text { o, } \\
\text { conservative }\end{array}$ \\
\hline $\begin{array}{l}\text { Wolfe v. North } \\
\text { Carolina, } 364 \text { U.S. } \\
177 \text { (1960). }\end{array}$ & $\begin{array}{l}\text { Dismissing appeal of trespass conviction of attending } \\
\text { segregated park for not properly offering federal integration } \\
\text { order. Dissent (Warren with all), "[A]ppellants offered the } \\
\text { [relevant] record in evidence." }\end{array}$ & $\begin{array}{l}\mathrm{S} \text { o c i a } 1 \text {, } \\
\text { conservative }\end{array}$ \\
\hline $\begin{array}{l}\text { McPhaul v. United } \\
\text { States, } 364 \text { U.S. } \\
372(1960) \text {. }\end{array}$ & $\begin{array}{l}\text { Affirming conviction for failure to produce documents } \\
\text { requested by the Committee on Un-American Activities. } \\
\text { Dissent (Douglas with all), "If Congress desires to have the } \\
\text { judiciary adjudge a man guilty for failure to produce } \\
\text { documents, the prosecution should be required to prove that the } \\
\text { man whom we send to prison had the power to produce them." }\end{array}$ & $\begin{array}{l}\mathrm{S} \text { o c i a } 1 \text {, } \\
\text { conservative }\end{array}$ \\
\hline $\begin{array}{l}\text { Polites v. United } \\
\text { States, } 364 \text { U.S. } \\
426(1960) .\end{array}$ & $\begin{array}{l}\text { Affirming de-naturalization due to membership in Communist } \\
\text { Party. Dissent (Brennan with all) would remand for District } \\
\text { Court to exercise "discretion under Rule 60(b)(5)." }\end{array}$ & $\begin{array}{l}\mathrm{S} \text { o c i a } 1 \text {, } \\
\text { conservative }\end{array}$ \\
\hline $\begin{array}{l}\text { Times Film Corp. } \\
\text { v. City of Chicago, } \\
365 \text { U.S. } 43 \text { (1961). }\end{array}$ & $\begin{array}{l}\text { Upholding film-approval ordinance. Dissent } 1 \text { (Warren with } \\
\text { all), "[T]he Court . . . , in exalting the censor of motion } \\
\text { pictures, has endangered the First and Fourteenth Amendment } \\
\text { rights of all others engaged in the dissemination of ideas." } \\
\text { Dissent } 2 \text { (Douglas with Warren \& Black), against censorship. }\end{array}$ & $\begin{array}{l}\mathrm{S} p \text { e e c h } \\
\text { conservative }\end{array}$ \\
\hline
\end{tabular}




\begin{tabular}{|c|c|c|}
\hline $\begin{array}{l}\text { Wilkinson } \mathrm{v} . \\
\text { United States, } 365 \\
\text { U.S. } 399(1961) \text {. }\end{array}$ & $\begin{array}{l}\text { Upholding conviction for refusing to answer questions of } \\
\text { Committee on Un-American Activities. Dissent } 1 \text { (Black with } \\
\text { Warren \& Douglas) "regard[s] . . unlimited sweep of the } \\
\text { [precedent] a compelling reason, not to reaffirm that case, but } \\
\text { to overrule it." Dissent } 2 \text { (Douglas with Warren \& Black), the } \\
\text { Committee does not have authority to prosecute its critics. } \\
\text { Dissent } 3 \text { (Brennan with Douglas), "[T] he dominant purpose of } \\
\text { these questions was ... to harass the petitioner...." }\end{array}$ & $\begin{array}{l}\text { S o c i a } 1 \text {, } \\
\text { conservative }\end{array}$ \\
\hline $\begin{array}{l}\text { Braden v. United } \\
\text { States, } 365 \text { U.S. } \\
431(1961) .\end{array}$ & $\begin{array}{l}\text { Upholding conviction for refusing to answer questions of } \\
\text { Committee on Un-American Activities. Dissent } 1 \text { (Black with } \\
\text { Warren \& Douglas), "The majority's approach makes the First } \\
\text { Amendment, not the rigid protection of liberty its language } \\
\text { imports, but a poor flexible imitation." Dissent } 2 \text { (Douglas with } \\
\text { all), "[B]efore inroads in the First Amendment domain may be } \\
\text { made, some demonstrable connection with communism must } \\
\text { first be established...." }\end{array}$ & $\begin{array}{l}\text { S o c i a } 1 \text {, } \\
\text { conservative }\end{array}$ \\
\hline $\begin{array}{l}\text { Green v. } \text { United } \\
\text { States, } 365 \text { U.S. } \\
301(1961) .\end{array}$ & $\begin{array}{l}\text { Affirming criminal conviction despite that mitigating statement } \\
\text { was made through counsel. Dissent (Black with all) would } \\
\text { remand. }\end{array}$ & $\begin{array}{l}\mathrm{C} \text { i } \mathrm{v} \mathrm{P} r \mathrm{o}, \\
\text { conservative }\end{array}$ \\
\hline $\begin{array}{l}\text { Konigsberg v. State } \\
\text { Bar of California, } \\
\text { 366 U.S. 36(1961). }\end{array}$ & $\begin{array}{l}\text { Upholding denial of eligibility for bar membership on the basis } \\
\text { of refusal to answer about Communist Party membership. } \\
\text { Dissent } 1 \text { (Black with Warren \& Douglas), "[T]his case must } \\
\text { take its place in the ever-lengthening line of cases in which } \\
\text { individual liberty to think, speak, write, associate and petition } \\
\text { is being abridged in a manner precisely contrary to the explicit } \\
\text { commands of the First Amendment." Dissent } 2 \text { (Brennan with } \\
\text { Warren), precedent requires that the committee of the bar } \\
\text { should show defendant "advocated the otherthrow of the } \\
\text { Government." }\end{array}$ & $\begin{array}{l}\text { S o c i a } 1, \\
\text { conservative }\end{array}$ \\
\hline $\begin{array}{l}\text { In re Anastaplo, } \\
\text { 366 U.S. } 82 \text { (1961). }\end{array}$ & $\begin{array}{l}\text { Upholding denial of bar membership for refusing to answer } \\
\text { questions about Communist Party membership. Dissent } 1 \\
\text { (Black with all), "Too many men are being driven to become } \\
\text { government-fearing . . . because the Government is being } \\
\text { permitted to strike out at those who are fearless enough to think } \\
\text { as they please and say what they think." Dissent } 2 \text { (Brennan } \\
\text { with Warren), also against precedent as was Konigsberg, } 366 \\
\text { U.S. at } 80 \text {. }\end{array}$ & $\begin{array}{l}\text { S o c i a } 1 \text {, } \\
\text { conservative }\end{array}$ \\
\hline $\begin{array}{l}\text { Cohen v. Hurley, } \\
366 \text { U.S. } 117 \\
(1961) \text {. }\end{array}$ & $\begin{array}{l}\text { Upholding disbarment for refusing to answer Communist Party } \\
\text { membership questions. Dissent } 1 \text { (Black with Warren \& } \\
\text { Douglas), "[T]he majority is here approving a practice that } \\
\text { makes the constitutional privilege against self-incrimination } \\
\text { the 'phrase without reality."' Dissent } 2 \text { (Douglas with Black), } \\
\text { "The privilege against self-incrimination contained in the Fifth } \\
\text { Amendment has an honorable history and should not be } \\
\text { downgraded as it is today." Dissent } 3 \text { (Brennan with Warren), } \\
\text { "[P]etitioner was protected by the immunity from compulsory } \\
\text { self-incrimination guaranteed by the Fifth Amendment.... }\end{array}$ & $\begin{array}{l}\mathrm{S} \text { o c i a } 1, \\
\text { conservative }\end{array}$ \\
\hline
\end{tabular}




\begin{tabular}{|c|c|c|}
\hline $\begin{array}{l}\text { Smith v. Butler, } \\
366 \text { U.S. } 161 \\
(1961) \text {. }\end{array}$ & $\begin{array}{l}\text { Dismissing certiorari effectively precluding liability to } \\
\text { employee. Dissent } 1 \text { (Brennan with Warren \& Black), "I would } \\
\text { reverse and remand the cause with direction to enter an order } \\
\text { reinstating the judgment in favor of the petitioner." Dissent } 2 \\
\text { (Douglas) would remand for a new trial. }\end{array}$ & $\begin{array}{l}\mathrm{T} \text { o } \mathrm{r} \quad \mathrm{t}, \\
\text { conservative }\end{array}$ \\
\hline $\begin{array}{l}\text { Communist Party } \\
\text { of The United } \\
\text { S t a t e s v . } \\
\text { S u b v e r s i v e } \\
\text { Activities Control } \\
\text { Bd., } 367 \text { U.S. } 1 \\
(1961) \text {. }\end{array}$ & $\begin{array}{l}\text { Upholding registration requirement. Dissent } 1 \text { (Warren), "[T]he } \\
\text { Act does constitute a violation of the Fifth Amendment." } \\
\text { Dissent } 2 \text { (Black), "The first banning of an association because } \\
\text { it advocates hated ideas . . . marks a fateful moment in the } \\
\text { history of a free country." Dissent } 3 \text { (Douglas), "Congress can } \\
\text { require full disclosure of all the paraphernalia through which } \\
\text { a foreign dominated and controlled organization spreads } \\
\text { propaganda, engages in agitation, or promotes politics in this } \\
\text { country. But the Fifth Amendment bars Congress from } \\
\text { requiring full disclosure by one Act and by another Act making } \\
\text { the facts admitted or disclosed under compulsion the } \\
\text { ingredients of a crime." Dissent } 4 \text { (Brennan with Warren), } \\
\text { "[O]fficials cannot be compelled to [register] without abridging } \\
\text { their privilege against self-incrimination." }\end{array}$ & $\begin{array}{l}\mathrm{S} \text { o c i a } 1, \\
\text { conservative }\end{array}$ \\
\hline $\begin{array}{l}\text { Scales v. United } \\
\text { States, } 367 \text { U.S. } \\
203(1961) .\end{array}$ & $\begin{array}{l}\text { Upholding conviction for membership in party advocating the } \\
\text { violent overthrow of the government. Dissent } 1 \text { (Black), } \\
\text { "[P]etitioner has been convicted under a law that is, at best, } \\
\text { unconstitutionally vague and, at worst, ex post facto." Dissent } \\
2 \text { (Douglas), "[W]e make a sharp break with traditional } \\
\text { concepts of First Amendment rights." Dissent } 3 \text { (Brennan with } \\
\text { Warren \& Douglas), defendant has statutory immunity. }\end{array}$ & $\begin{array}{l}\mathrm{S} \text { o c i a } 1, \\
\text { conservative }\end{array}$ \\
\hline $\begin{array}{l}\text { Gori v. United } \\
\text { States, } 367 \text { U.S. } \\
364(1961) .\end{array}$ & $\begin{array}{l}\text { Conviction after mistrial is not double jeopardy. Dissent } \\
\text { (Douglas with all), "The policy of the Bill of Rights is to make } \\
\text { rare indeed the occasions when the citizen can for the same } \\
\text { offense be required to run the gantlet twice." }\end{array}$ & $\begin{array}{l}\mathrm{C} \mathrm{r} \mathrm{i} \mathrm{m} \mathrm{P} \mathrm{r} \mathrm{o,} \\
\text { conservative }\end{array}$ \\
\hline $\begin{array}{l}\text { C a feteria \& } \\
\text { R e s t a u r a n t } \\
\text { Workers Union, } \\
\text { Local } 473 \quad \text { v. } \\
\text { McElroy, } 367 \text { U.S. } \\
886(1961) .\end{array}$ & $\begin{array}{l}\text { Military leader of base may exclude civilian employee of } \\
\text { contractor summarily without notice. Dissent (Brennan with } \\
\text { all), deserved due process. }\end{array}$ & $\begin{array}{l}\text { A } \mathrm{d} \mathrm{m} \mathrm{i} \mathrm{n}, \\
\text { conservative }\end{array}$ \\
\hline $\begin{array}{l}\text { Killian v. United } \\
\text { States, } 368 \text { U.S. } \\
231(1961) .\end{array}$ & $\begin{array}{l}\text { Upholding prosecution for false oath of no membership of } \\
\text { Communist Party. Dissent } 1 \text { (Black), "[T]he Constitution } \\
\text { absolutely prohibits the Government from sending people to } \\
\text { jail for 'crimes' that arise out of, and indeed are manufactured } \\
\text { out of, the imposition of test oaths that invade the freedoms of } \\
\text { belief and political association.... " Dissent } 2 \text { (Douglas with } \\
\text { Warren \& Black), "Membership, as that word is used in the } \\
\text { Act, should be proved by facts which tie the accused to the } \\
\text { illegal aims of the party." }\end{array}$ & $\begin{array}{l}\mathrm{S} \text { o c i a } 1, \\
\text { conservative }\end{array}$ \\
\hline $\begin{array}{l}\text { Hill v. United } \\
\text { States, } 368 \text { U.S. } \\
424(1962) .\end{array}$ & $\begin{array}{l}\text { Upholding conviction despite no opportunity to make } \\
\text { mitigating statement. Dissent (Black with all), the violation of } \\
\text { defendant's right to speak in mitigation is grounds for false } \\
\text { sentence. }\end{array}$ & $\begin{array}{l}\text { C r i m P r o, } \\
\text { conservative }\end{array}$ \\
\hline
\end{tabular}




\begin{tabular}{|l|l|l|}
\hline $\begin{array}{l}\text { Oyler v. Boles, 368 } \\
\text { U.S. } 448 \text { (1962). }\end{array}$ & $\begin{array}{l}\text { Upholding habitual-offender conviction. Dissent (Douglas with } \\
\text { all), notice was inadequate, "procedural due process has not } \\
\text { been satisfied." }\end{array}$ & \begin{tabular}{l} 
conservative \\
\hline
\end{tabular} \\
\hline
\end{tabular}

\section{Appendix B3: Tables of Powell Composition Majorities Producing More than Two 5-4 Opinions}

We list the opinions of the United States Supreme Court while its composition is defined by its junior justice being Powell (and Rehnquist, they were appointed the same day). The Powell composition consists of three appointees of Democratic presidents (Douglas, Marshall, and White) and six appointees of Republican presidents (Blackmun, Brennan, Burger, Powell, Rehnquist, and Stewart). We list the majorities as they appear in the corresponding figure in the full-text proceeding clockwise from the nine o'clock position. The name of the case, along with the citation to the United States Reporter, and the year appears in the first column. The second column holds our brief description of the outcome compared to the dissent's position. The third column holds the legal field and the political slant of the majority's position as it arises by juxtaposition to that of the minority. We sort the justices in the majorities by, first, the chief justice, then the associate justices by alphabetical order.

\section{BRENNAN-Douglas-MARShalL-STEWART-White (Nine O'ClOCK)}

\begin{tabular}{|c|c|c|}
\hline $\begin{array}{l}\text { Loper v. Beto, } \\
405 \text { U.S. } 473 \\
(1972) .\end{array}$ & $\begin{array}{l}\text { Prosecution cannot use against defendant prior convictions } \\
\text { obtained without assistance of counsel. Dissents would allow. }\end{array}$ & CrimPro, liberal \\
\hline $\begin{array}{l}\text { Deepsouth Packing } \\
\text { Co. v. Laitram } \\
\text { Corp., } 406 \text { U.S. } \\
518 \text { (1972). }\end{array}$ & $\begin{array}{l}\text { May infringer export machines before final assembly? } \\
\text { Majority, yes. Dissent (Blackmun with Burger, Powell, \& } \\
\text { Rehnquist), no. }\end{array}$ & Patent, liberal \\
\hline $\begin{array}{l}\text { Wright v. Council } \\
\text { of Emporia, } 407 \\
\text { U.S. } 451 \text { (1972). }\end{array}$ & $\begin{array}{l}\text { School desegregation cannot be circumvented by creating new } \\
\text { school district. Dissent (Burger with Blackmun, Powell, \& } \\
\text { Rehnquist), not clear that new school would perpetuate } \\
\text { discrimination. }\end{array}$ & Social, liberal \\
\hline $\begin{array}{l}\text { Gelbard v. United } \\
\text { States, } 408 \text { U.S. } 41 \\
\text { (1972). }\end{array}$ & $\begin{array}{l}\text { No obligation to testify before grand jury about discussions } \\
\text { obtained by illegal wiretaps. Dissent (Rehnquist with Burger, } \\
\text { Blackmun, \& Powell) argues majority finds illegality of } \\
\text { wiretap too easily. }\end{array}$ & CrimPro, liberal \\
\hline $\begin{array}{l}\text { F u r m a n v. } \\
\text { Georgia., } 408 \text { U.S. } \\
238 \text { (1972). }\end{array}$ & Death penalty is cruel and unusual punishment. Dissents, no. & Criml, liberal \\
\hline $\begin{array}{l}\text { U.S. Dep't. of } \\
\text { Agric. v. Murry, } \\
413 \text { U.S. } 508 \\
(1973) \text {. }\end{array}$ & $\begin{array}{l}\text { Due process; Food stamp recipients could be dependents of } \\
\text { taxpayers who could not receive food stamps. Dissents, no. }\end{array}$ & Social, liberal \\
\hline $\begin{array}{l}\text { Plummer v. City of } \\
\text { Columbus, } 414 \\
\text { U.S. } 2 \text { (1973). }\end{array}$ & $\begin{array}{l}\text { Defendant can take advantage of facial unconstitutionality (for } \\
\text { vagueness) of ordinance under which convicted. }\end{array}$ & CrimPro, liberal \\
\hline
\end{tabular}




\begin{tabular}{|l|l|l|}
\hline $\begin{array}{l}\text { United States v. } \\
\text { Giordano, 416 U.S. } \\
505 \text { (1974). }\end{array}$ & Attorney General's secretary could not approve wiretaps. & CrimPro, liberal \\
\hline $\begin{array}{l}\text { Goss v. Lopez, 419 } \\
\text { U.S. 565 (1975). }\end{array}$ & $\begin{array}{l}\text { School students facing suspension are entitled to notice and } \\
\text { hearing. }\end{array}$ & Social, liberal \\
\hline W o o d v . & $\begin{array}{l}\text { School officials exceeded boundaries. Dissent (Powell with } \\
\text { Strickland, 420 } \\
\text { Burger, Blackmun, \& Rehnquist) would not subject them to as } \\
\text { U.S. 308 (1975). }\end{array}$ & Social, liberal \\
\hline
\end{tabular}

\section{BRENNAN-DOUGLAS-MARSHALL-POWELL-STEWART (TEN O'ClOCK)}

\begin{tabular}{|l|l|l|}
\hline $\begin{array}{l}\text { Almota Farmers } \\
\text { Elevator \& } \\
\text { Warehouse Co. v. } \\
\text { United States, } \\
409 \text { U.S. } 470 \\
\text { (1973). }\end{array}$ & $\begin{array}{l}\text { Takings, condemnation valuation should also account for } \\
\text { improvements beyond lease term. Dissent (Rehnquist with } \\
\text { Burger, White, \& Blackmun) would not include them. }\end{array}$ & Takings, liberal \\
\hline $\begin{array}{l}\text { Almeida-Sanchez } \\
\text { v. United States, } \\
413 \quad \text { U.S. 266 } \\
\text { (1973). }\end{array}$ & $\begin{array}{l}\text { Warrantless search within 100 miles from border, despite } \\
\text { statutory authorization, violates Fourth Amendment. Dissent }\end{array}$ & CrimPro, liberal \\
\hline $\begin{array}{l}\text { Fla. Power \& Light } \\
\text { Co. v. Int'l Bhd. of } \\
\text { Elec. Workers, } \\
\text { Local 641, 417 } \\
\text { U.S. 790 (1974). }\end{array}$ & $\begin{array}{l}\text { Union members sanctioned for crossing picket line committed } \\
\text { Blackmun, \& Rehnquist), yes. }\end{array}$ & Employment, \\
\end{tabular}

\section{BURGER-BLACKMUN-BRENNAN-REHNQUIST-WHITE (TWO O'CLOCK)}

\begin{tabular}{|c|c|c|}
\hline $\begin{array}{l}\text { Moore v. Illinois, } \\
408 \text { U.S. } 786 \\
(1972) .\end{array}$ & $\begin{array}{l}\text { Death penalty, Illinois cannot execute. Dissent (Marshall with } \\
\text { Douglas, Stewart, \& Powell), it can. }\end{array}$ & Criml, liberal \\
\hline $\begin{array}{l}\text { Ricci v. } \text { Chi. } \\
\text { Mercantile Exch., } \\
409 \text { U.S. } 289 \\
(1973) .\end{array}$ & $\begin{array}{l}\text { Majority wants antitrust litigants to obtain reaction from the } \\
\text { Commodity Exchange Commission. Dissents find it pointless. }\end{array}$ & Business, libera \\
\hline $\begin{array}{l}\text { Colgrove v. Battin, } \\
413 \text { U.S. } 149 \\
(1973) .\end{array}$ & $\begin{array}{l}\text { Six-member jury is valid for civil trials. Dissent } 1 \text { (Douglas } \\
\text { with Powell), no. Dissent } 2 \text { (Marshall with Stewart) would not } \\
\text { reach merits. If about tort then liberal, if about CivPro then } \\
\text { conservative. }\end{array}$ & $\begin{array}{l}\mathrm{C} \text { i } \mathrm{v} \mathrm{P} \mathrm{r} \text { o } \\
\text { conservative }\end{array}$ \\
\hline $\begin{array}{l}\text { Renegotiation } \\
\text { B o a r d v . } \\
\text { B a n e r c r a ft } \\
\text { Clothing Co., } 415 \\
\text { U.S. } 1 \text { (1974). }\end{array}$ & $\begin{array}{l}\text { Government contractors did not have Freedom of Information } \\
\text { Act (FOIA) right to documents of the Renegotiation [of } \\
\text { Government Contracts] Board in part because merits come } \\
\text { later. Dissent (Douglas with Stewart, Marshall, \& Powell) } \\
\text { thinks contractors had exhausted their remedies and their plea } \\
\text { should win. }\end{array}$ & $\begin{array}{l}\text { A } \mathrm{d} \mathrm{m} \mathrm{i} \mathrm{n} \\
\text { conservative }\end{array}$ \\
\hline
\end{tabular}




\begin{tabular}{|l|l|l|}
\hline $\begin{array}{l}\text { Muniz v. Hoffman, } \\
422 \text { U.S. } 454 \\
(1975) .\end{array}$ & $\begin{array}{l}\text { Union and its officer did not have right to jury trial under } \\
\text { National Labor Relations Act. Dissents think statute awards } \\
\text { right to jury trial. }\end{array}$ & $\begin{array}{l}\text { Employment, } \\
\text { conservative }\end{array}$ \\
\hline
\end{tabular}

\section{BURGER-BLACKMUN-POWELL-REHNQUIST-WHITE (THREE O'CLOCK)}

\begin{tabular}{|c|c|c|}
\hline $\begin{array}{l}\text { Johnson v. } \\
\text { Louisiana, } 406 \\
\text { U.S. } 356 \text { (1972). }\end{array}$ & $\begin{array}{l}\text { Upholding Louisiana law allowing 9-3 jury conviction. } \\
\text { Dissent would require a unanimous jury. }\end{array}$ & $\begin{array}{l}\text { C r i m P r o, } \\
\text { conservative }\end{array}$ \\
\hline $\begin{array}{l}\text { A p o d a c a } \mathrm{v} \text {. } \\
\text { Oregon, } 406 \text { U.S. } \\
404 \text { (1972). }\end{array}$ & $\begin{array}{l}\text { Upholding Oregon law allowing } 10-2 \text { jury conviction. Dissent } \\
\text { would require a unanimous jury. }\end{array}$ & $\begin{array}{l}\text { C r i m P r o, } \\
\text { conservative }\end{array}$ \\
\hline $\begin{array}{l}\text { J e fferson } \quad \text { v. } \\
\text { Hackney, } 406 \text { U.S. } \\
535 \text { (1972). }\end{array}$ & $\begin{array}{l}\text { The system that Texas uses to compute Aid to Families with } \\
\text { Dependent Children is proper despite minor inequalities. } \\
\text { Dissent would invalidate. }\end{array}$ & $\begin{array}{l}\mathrm{S} \text { o c i a } 1 \\
\text { conservative }\end{array}$ \\
\hline $\begin{array}{l}\text { M i } 1 \text { t o n } \quad \mathrm{v} \text {. } \\
\text { Wainwright, } 407 \\
\text { U.S. } 371 \text { (1972). }\end{array}$ & $\begin{array}{l}\text { Admission of guilt to undercover police in jail proper. Dissent } \\
\text { disagrees. }\end{array}$ & $\begin{array}{l}\text { C r i m P r o, } \\
\text { conservative }\end{array}$ \\
\hline $\begin{array}{l}\text { Lloyd Corp. v. } \\
\text { Tanner, } 407 \text { U.S. } \\
551 \text { (1972). }\end{array}$ & $\begin{array}{l}\text { Shopping center was allowed to prohibit distribution of flyers } \\
\text { on its premises. Dissent finds a First Amendment violation. }\end{array}$ & $\begin{array}{l}\text { S o c i a } 1 \text {, } \\
\text { conservative }\end{array}$ \\
\hline $\begin{array}{l}\text { Laird v. Tatum, } \\
408 \text { U.S. } 1 \text { (1972). }\end{array}$ & $\begin{array}{l}\text { Army surveillance of lawful protests did not violate the First } \\
\text { Amendment. Dissent finds it does. }\end{array}$ & $\begin{array}{l}\text { S o c i a } 1 \\
\text { conservative }\end{array}$ \\
\hline $\begin{array}{l}\text { Gravel v. United } \\
\text { States, } 408 \text { U.S. } \\
606(1972) .\end{array}$ & $\begin{array}{l}\text { The 'inquiry and debate' clause does not immunize senator and } \\
\text { aid from prosecution for publication of military secrets } \\
\text { (pentagon papers). Dissents would give immunities. }\end{array}$ & $\begin{array}{l}\text { A } \mathrm{d} \mathrm{m} \mathrm{i} \mathrm{n} \text {, } \\
\text { conservative }\end{array}$ \\
\hline $\begin{array}{l}\text { Branzburg v. } \\
\text { Hayes, } 408 \text { U.S. } \\
665 \text { (1972). }\end{array}$ & $\begin{array}{l}\text { First Amendment does not relieve reporter from responding to } \\
\text { criminal grand jury subpoena about confidential sources. }\end{array}$ & $\begin{array}{l}\mathrm{S} \text { p e e c h } \\
\text { conservative }\end{array}$ \\
\hline $\begin{array}{l}\text { United States v. } \\
\text { Kras, } 409 \text { U.S. } 434 \\
(1973) .\end{array}$ & $\begin{array}{l}\text { Filing fee for obtaining discharge in bankruptcy does not deny } \\
\text { indigents equal protection. Dissent finds it does. }\end{array}$ & $\begin{array}{l}\text { S o c i a } 1 \\
\text { conservative }\end{array}$ \\
\hline $\begin{array}{l}\text { Dep't of Motor } \\
\text { Vehicles v. Rios, } \\
410 \text { U.S. } 425 \\
(1973) \text {. }\end{array}$ & $\begin{array}{l}\text { California Supreme Court requires hearing before suspension } \\
\text { of license on both California and Federal constitutional } \\
\text { grounds. Reversed to clarify which. Dissent would deny } \\
\text { certiorari, these reversals are improvident. }\end{array}$ & $\begin{array}{l}\text { A } \mathrm{d} \mathrm{m} \mathrm{i} \mathrm{n}, \\
\text { conservative }\end{array}$ \\
\hline $\begin{array}{l}\text { Ortwein v. Schwab, } \\
410 \quad \text { U.S. } \quad 656 \\
(1973) \text {. }\end{array}$ & $\begin{array}{l}\text { Oregon twenty-five dollar filing fee to challenge denial of } \\
\text { welfare does not violate equal protection. Dissent finds it does; } \\
\text { same dissents as in Kras. }\end{array}$ & $\begin{array}{l}\text { S o c i a } 1 \\
\text { conservative }\end{array}$ \\
\hline $\begin{array}{l}\text { Lavallee v. Delle } \\
\text { Rose, } 410 \text { U.S. } 690 \\
(1973) .\end{array}$ & $\begin{array}{l}\text { Reversing lower court grants of habeas corpus for improper use } \\
\text { of confessions. Dissent disagrees. }\end{array}$ & $\begin{array}{l}\text { C r i m P r o, } \\
\text { conservative }\end{array}$ \\
\hline $\begin{array}{l}\text { United States v. } \\
\text { Russell, } 411 \text { U.S. } \\
423 \text { (1973). }\end{array}$ & $\begin{array}{l}\text { Undercover provision of legal substance did not result in } \\
\text { entrapment of drug maker. }\end{array}$ & $\begin{array}{l}\mathrm{C} \mathrm{r} \text { i m P r o, } \\
\text { conservative }\end{array}$ \\
\hline $\begin{array}{l}\text { C h a ffi n } \\
\text { Stynchcombe, } 412 \\
\text { U.S. } 17 \text { (1973). }\end{array}$ & Higher sentence upon retrial does not offend double jeopardy. & $\begin{array}{l}\mathrm{C} \text { r i m P r o, } \\
\text { conservative }\end{array}$ \\
\hline
\end{tabular}




\begin{tabular}{|c|c|c|}
\hline $\begin{array}{l}\text { M i } 11 \text { e r } \quad \mathrm{v} . \\
\text { California, } 413 \\
\text { U.S. } 15(1973) \text {. }\end{array}$ & $\begin{array}{l}\text { Upholds obscenity conviction and expands obscenity } \\
\text { definition. Dissents disagree. }\end{array}$ & $\begin{array}{l}\text { S o c i a } 1 \text {, } \\
\text { conservative }\end{array}$ \\
\hline $\begin{array}{l}\text { Paris Adult Theatre } \\
\text { I v. Slaton, } 413 \\
\text { U.S. } 49 \text { (1973). }\end{array}$ & $\begin{array}{l}\text { Upholds injunction against showing obscene movies and } \\
\text { expands definition. }\end{array}$ & $\begin{array}{l}\text { S o c i a } 1 \\
\text { conservative }\end{array}$ \\
\hline $\begin{array}{l}\text { K a p } 1 \text { a } n \quad v \text {. } \\
\text { California, } 413 \\
\text { U.S. } 115(1973) .\end{array}$ & $\begin{array}{l}\text { Upholds obscenity conviction of adult bookstore operator (no } \\
\text { images) and expands definition. }\end{array}$ & $\begin{array}{l}\text { S o c i a } 1 \\
\text { conservative }\end{array}$ \\
\hline $\begin{array}{l}\text { United States v. } 12 \\
\text { 200-Ft. Reels of } \\
\text { Super 8mm Film, } \\
413 \text { U.S. } 123 \\
(1973) .\end{array}$ & $\begin{array}{l}\text { Upholds forfeiture of obscene films imported by private } \\
\text { individual. }\end{array}$ & $\begin{array}{l}\text { S o c i a } 1 \\
\text { conservative }\end{array}$ \\
\hline $\begin{array}{l}\text { United States v. } \\
\text { Orito, } 413 \text { U.S. } 139 \\
(1973) .\end{array}$ & Upholds prohibition against transportation of obscene material. & $\begin{array}{l}\text { S o c i a } 1, \\
\text { conservative }\end{array}$ \\
\hline $\begin{array}{l}\text { C a d y v . } \\
\text { Dombrowski, } 413 \\
\text { U.S. } 433 \text { (1973). }\end{array}$ & $\begin{array}{l}\text { Warrantless search of car towed for being disabled does not } \\
\text { trigger exclusionary rule. }\end{array}$ & $\begin{array}{l}\text { C r i m P r o } \\
\text { conservative }\end{array}$ \\
\hline $\begin{array}{l}\text { Heller v. New } \\
\text { York, } 413 \text { U.S. } 483 \\
(1973) \text {. }\end{array}$ & $\begin{array}{l}\text { Adversary hearing prior to seizure was not required because } \\
\text { the judge issuing the warrant saw the entire obscene film. }\end{array}$ & $\begin{array}{l}\text { S o c i a } 1 \text {, } \\
\text { conservative }\end{array}$ \\
\hline $\begin{array}{l}\text { Broadrick } \quad \text {. } \\
\text { Oklahoma, } 413 \\
\text { U.S. } 601(1973) .\end{array}$ & $\begin{array}{l}\text { Statutory limitation of partisan activities of public employees } \\
\text { is proper. }\end{array}$ & $\begin{array}{l}\text { S o c i a } 1 \text {, } \\
\text { conservative }\end{array}$ \\
\hline $\begin{array}{l}\text { Gosa v. Mayden, } \\
413 \text { U.S. } 665 \\
(1973) \text {. }\end{array}$ & $\begin{array}{l}\text { Convicted servicemen are not entitled to retroactive application } \\
\text { of new constitutional principle that martial courts cannot } \\
\text { convict for offenses against civilians. }\end{array}$ & $\begin{array}{l}\text { C r i m P r o, } \\
\text { conservative }\end{array}$ \\
\hline $\begin{array}{l}\text { Alexander v. } \\
\text { Virginia, } 413 \text { U.S. } \\
836(1973) .\end{array}$ & $\begin{array}{l}\text { Jury is not required in civil proceeding against obscene } \\
\text { material. }\end{array}$ & $\begin{array}{l}\text { S o c i a } 1 \\
\text { conservative }\end{array}$ \\
\hline $\begin{array}{l}\text { United States v. } \\
\text { Edwards, } 415 \text { U.S. } \\
800 \text { (1974). }\end{array}$ & $\begin{array}{l}\text { Warrantless seizure of clothing over ten hours after arrest is } \\
\text { proper. }\end{array}$ & $\begin{array}{l}\text { C r i m P r o, } \\
\text { conservative }\end{array}$ \\
\hline $\begin{array}{l}\text { United States v. } \\
\text { Chavez, } 416 \text { U.S. } \\
562 \text { (1974). }\end{array}$ & $\begin{array}{l}\text { If Attorney General actually authorized warrant even if court } \\
\text { did not state so, evidence not suppressed. }\end{array}$ & $\begin{array}{l}\text { C r i m P r o } \\
\text { conservative }\end{array}$ \\
\hline $\begin{array}{l}\text { Mitchell v. W. T. } \\
\text { Grant Co., } 416 \\
\text { U.S. } 600 \text { (1974). }\end{array}$ & Sequestration of collateral without hearing is proper. & $\begin{array}{l}\text { B u s in e s s, } \\
\text { conservative }\end{array}$ \\
\hline $\begin{array}{l}\text { Cardwell v. Lewis, } \\
417 \text { U.S. } 583 \\
(1974) \text {. }\end{array}$ & $\begin{array}{l}\text { Warrantless search of car exterior was proper with probable } \\
\text { cause. }\end{array}$ & $\begin{array}{l}\text { C r i m P r o, } \\
\text { conservative }\end{array}$ \\
\hline $\begin{array}{l}\text { Hamling v. United } \\
\text { States, } 418 \text { U.S. } 87 \\
\text { (1974). }\end{array}$ & $\begin{array}{l}\text { Upholding conviction for publication of illustrated version of } \\
\text { the Presidential Report of the Commission on Obscenity and } \\
\text { Pornography. }\end{array}$ & $\begin{array}{l}\text { S o c i a } 1 \\
\text { conservative }\end{array}$ \\
\hline $\begin{array}{l}\text { United States v. } \\
\text { Richardson, } 418 \\
\text { U.S. } 166(1974) .\end{array}$ & $\begin{array}{l}\text { Taxpayer cannot force the Central Intelligence Agency to } \\
\text { turnover spending receipts. }\end{array}$ & $\begin{array}{l}\text { S o c i a } 1 \\
\text { conservative }\end{array}$ \\
\hline
\end{tabular}




\begin{tabular}{|c|c|c|}
\hline $\begin{array}{l}\text { Am. Radio Ass'n. } \\
\text { v. Mobile S.S. } \\
\text { Ass'n., } 419 \text { U.S. } \\
215 \text { (1974). }\end{array}$ & $\begin{array}{l}\text { Upholds Alabama courts' injunction against picketing by } \\
\text { maritime employees in Mobile. Dissent considers it preempted } \\
\text { by the National Labor Relations Act. }\end{array}$ & $\begin{array}{l}\text { Employment, } \\
\text { conservative }\end{array}$ \\
\hline $\begin{array}{l}\text { E s t e } 11 \text { e v. } \\
\text { Dorrough, } 420 \text { U.S. } \\
534 \text { (1975). }\end{array}$ & $\begin{array}{l}\text { Per curiam. Texas's automatic dismissal of pending appeal by } \\
\text { escaped felon proper. Dissent disagrees. }\end{array}$ & $\begin{array}{l}\text { C } \mathrm{r} \text { i } \mathrm{m} 1 \text {, } \\
\text { conservative }\end{array}$ \\
\hline $\begin{array}{l}\text { Iannelli v. United } \\
\text { States, } 420 \text { U.S. } \\
770(1975) .\end{array}$ & $\begin{array}{l}\text { Double jeopardy does not prevent conviction for conspiracy to } \\
\text { conduct gambling business and participation in gambling } \\
\text { operation. Dissent disagrees. }\end{array}$ & $\begin{array}{l}\text { C } \mathrm{r} \text { i } \mathrm{m} 1 \text {, } \\
\text { conservative }\end{array}$ \\
\hline $\begin{array}{l}\text { Connell Constr. } \\
\text { Co. v. Plumbers \& } \\
\text { Steamfitters Local } \\
\text { Union No. } 100 \text {, } \\
421 \text { U.S. } 616 \\
(1975) .\end{array}$ & $\begin{array}{l}\text { Allows use of antitrust against union. Dissent finds statutory } \\
\text { text excludes this application of antitrust. }\end{array}$ & $\begin{array}{l}\text { Employment, } \\
\text { conservative }\end{array}$ \\
\hline $\begin{array}{l}\text { Hicks v. Miranda, } \\
422 \text { U.S. } 332 \\
(1975) \text {. }\end{array}$ & $\begin{array}{l}\text { Obscenity; California seized films from theater; theater } \\
\text { countered in federal court obtaining ruling of } \\
\text { unconstitutionality of obscenity statute and finding authorities } \\
\text { harassed theater. Majority denies federal jurisdiction and } \\
\text { reverses harassment. }\end{array}$ & $\begin{array}{l}\text { S o c i a } 1 \text {, } \\
\text { conservative }\end{array}$ \\
\hline $\begin{array}{l}\text { United States v. } \\
\text { Peltier, } 422 \text { U.S. } \\
531 \text { (1975). }\end{array}$ & $\begin{array}{l}\text { Will not retroactively apply a later decision finding roving } \\
\text { border patrol warrantless searches improper. Dissent would } \\
\text { apply. }\end{array}$ & $\begin{array}{l}\text { C r i m P r o, } \\
\text { conservative }\end{array}$ \\
\hline $\begin{array}{l}\text { Bowen v. United } \\
\text { States, } 422 \text { U.S. } \\
916(1975) .\end{array}$ & $\begin{array}{l}\text { Will not retroactively apply a later decision finding roving } \\
\text { border patrol warrantless searches improper. Dissent would } \\
\text { apply. }\end{array}$ & $\begin{array}{l}\text { C r i m P r o, } \\
\text { conservative }\end{array}$ \\
\hline
\end{tabular}

\section{BURGER-BLACKMUN-POWELL-REHNQUIST-STEWART (FOUR O'CLOCK)}

\begin{tabular}{|l|l|l|}
\hline $\begin{array}{l}\text { Kirby v. Illinois, } \\
\text { 406 U.S. 682 } \\
\text { (1972). }\end{array}$ & $\begin{array}{l}\text { Robbery suspects did not have the right to have an attorney } \\
\text { present during lineup identification by victim. Dissent finds } \\
\text { suspects should. }\end{array}$ & $\begin{array}{l}\text { C r i m P r o } \\
\text { conservative }\end{array}$ \\
\hline $\begin{array}{l}\text { I } 11 \text { i n o i s v. } \\
\text { Somerville, 410 } \\
\text { U.S. 458 (1973). }\end{array}$ & $\begin{array}{l}\text { After defective indictment, trial court ordered mistrial, } \\
\text { allowing re-indictment and trial; defendant objected to mistrial, } \\
\text { mistrial was proper. Dissent finds double jeopardy should } \\
\text { attach under the circumstances. }\end{array}$ & $\begin{array}{l}\text { C r i m P r o, } \\
\text { conservative }\end{array}$ \\
\hline $\begin{array}{l}\text { San Antonio Indep. } \\
\text { Sch. Dist. v. } \\
\text { Rodriguez, 411 }\end{array}$ & $\begin{array}{l}\text { School funding; Texas scheme proper. Dissent disagrees } \\
\text { finding funding violates equal protection with no rational basis. }\end{array}$ & $\begin{array}{l}\text { S o c i a 1 } \\
\text { conservative }\end{array}$ \\
\hline $\begin{array}{l}\text { Falk v. Brennan, } 1973) . \\
\text { 414 U.S. 190 } \\
\text { (1973). }\end{array}$ & $\begin{array}{l}\text { Employer size for Fair Labor Standards Act; real estate } \\
\text { management company size was that of its commissions from } \\
\text { owners of its managed real estate. Dissent would include total } \\
\text { rents. }\end{array}$ & $\begin{array}{l}\text { Employment, } \\
\text { conservative }\end{array}$ \\
\hline
\end{tabular}




\begin{tabular}{|c|c|c|}
\hline $\begin{array}{l}\text { United States v. } \\
\text { Gen. Dynamics } \\
\text { Corp., } 415 \text { U.S. } \\
486(1974) .\end{array}$ & $\begin{array}{l}\text { Antitrust; District Court was justified in finding that } \\
\text { acquisition did not substantially lessen competition, market } \\
\text { was energy market. Dissent finds that the market is coal market } \\
\text { and regions of merging entities should not be defined by their } \\
\text { (different) freight rate districts; and that, yes, acquisition } \\
\text { lessened competition. }\end{array}$ & $\begin{array}{l}\text { B u s i n e s s, } \\
\text { conservative }\end{array}$ \\
\hline $\begin{array}{l}\text { Mayor of Phila. v. } \\
\text { Educ. Equal. } \\
\text { League, } 415 \text { U.S. } \\
605 \text { (1974). }\end{array}$ & $\begin{array}{l}\text { Educational equal protection challenge, denied. Dissent would } \\
\text { allow. }\end{array}$ & $\begin{array}{l}\text { S o c i a } 1 \\
\text { conservative }\end{array}$ \\
\hline $\begin{array}{l}\text { Arnett v. Kennedy, } \\
416 \text { U.S. } 134 \\
(1974) \text {. }\end{array}$ & $\begin{array}{l}\text { Lloyd-LaFollette Act adequately protects terminated federal } \\
\text { employees who need no more protection. Dissent would give } \\
\text { more protections under various clauses. }\end{array}$ & $\begin{array}{l}\text { Employment, } \\
\text { conservative }\end{array}$ \\
\hline $\begin{array}{l}\text { De Funis v. } \\
\text { Odegaard, } 416 \text { U.S. } \\
312 \text { (1974). }\end{array}$ & $\begin{array}{l}\text { Affirmative action challenge. Majority finds it moot because } \\
\text { student is graduating. Dissent would uphold policy. }\end{array}$ & $\begin{array}{l}\text { S o c i a } 1 \text {, } \\
\text { conservative }\end{array}$ \\
\hline $\begin{array}{l}\text { Scherk v. Alberto- } \\
\text { Culver Co., } 417 \\
\text { U.S. } 506 \text { (1974). }\end{array}$ & $\begin{array}{l}\text { Enforcing arbitration agreement in an international acquisition. } \\
\text { Dissent would not enforce, subjecting it to securities law. }\end{array}$ & $\begin{array}{l}\text { B u s i n e s s, } \\
\text { conservative }\end{array}$ \\
\hline $\begin{array}{l}\text { G i } 1 \text { m o r e } \quad \text {. } \\
\text { Montgomery, } 417 \\
\text { U.S. } 556(1974) \text {. }\end{array}$ & $\begin{array}{l}\text { Desegregating Montgomery, Alabama, city parks. Not a } 5-4 \\
\text { decision, multiple concurrences. }\end{array}$ & Dropped \\
\hline $\begin{array}{l}\text { Bangor Punta } \\
\text { Operations, Inc., v. } \\
\text { Bangor \& A. R. } \\
\text { Co., } 417 \text { U.S. } 703 \\
\text { (1974). }\end{array}$ & $\begin{array}{l}\text { Corporate looting recovery in favor of purchased corporate } \\
\text { parent barred equitably. Dissent would grant it. }\end{array}$ & $\begin{array}{l}\text { B u s i n e s s, } \\
\text { conservative }\end{array}$ \\
\hline $\begin{array}{l}\text { United States v. } \\
\text { Conn. Nat'l Bank, } \\
418 \text { U.S. } 656 \\
(1974) .\end{array}$ & $\begin{array}{l}\text { Antitrust, bank acquisition, allowed by lower court. Majority } \\
\text { remands for narrow market definition, not a potential market } \\
\text { definition. Dissent would adopt statewide potential market } \\
\text { definition. Conservative because the dissent is more anti- } \\
\text { acquisition than majority. }\end{array}$ & $\begin{array}{l}\text { B u s i n e s s, } \\
\text { conservative }\end{array}$ \\
\hline $\begin{array}{l}\text { Mil1iken v. } \\
\text { Bradley, } 418 \text { U.S. } \\
717 \text { (1974). }\end{array}$ & $\begin{array}{l}\text { School desegregation; Detroit's desegregation need not include } \\
\text { neighboring school districts. Dissent would include them. }\end{array}$ & $\begin{array}{l}\text { S o c i a } 1 \\
\text { conservative }\end{array}$ \\
\hline $\begin{array}{l}\text { Schlesinger v. } \\
\text { Ballard, } 419 \text { U.S. } \\
498(1975) .\end{array}$ & $\begin{array}{l}\text { Women navy officers allowed to have longer period with no } \\
\text { promotion before discharge. Dissent would find it a due } \\
\text { process violation. }\end{array}$ & $\begin{array}{l}\text { A } \mathrm{d} \mathrm{m} \mathrm{i} \mathrm{n} \text {, } \\
\text { conservative }\end{array}$ \\
\hline $\begin{array}{l}\text { Warth v. Seldin, } \\
422 \text { U.S. } 490 \\
(1975) .\end{array}$ & $\begin{array}{l}\text { Citizens do not have standing to challenge zoning producing } \\
\text { exclusion of poor people in suburb. Dissent would grant anti- } \\
\text { discrimination protection. }\end{array}$ & $\begin{array}{l}\text { S o c i a } 1 \\
\text { conservative }\end{array}$ \\
\hline $\begin{array}{l}\text { United States v. } \\
\text { Nat'l Ass'n of Sec. } \\
\text { Dealers, Inc., } 422 \\
\text { U.S. } 694 \text { (1975). }\end{array}$ & $\begin{array}{l}\text { Antitrust laws do not apply to SEC-regulated open-end mutual } \\
\text { fund marketing. Dissent would apply antitrust. }\end{array}$ & $\begin{array}{l}\text { B u s i n e s s, } \\
\text { conservative }\end{array}$ \\
\hline
\end{tabular}




\section{BURGER-BLACKMUN-REHNQUIST-STEWART-WHITE (FIVE O'CLOCK)}

\begin{tabular}{|c|c|c|}
\hline $\begin{array}{l}\text { United States v. Fuller, } 409 \text { U.S. } \\
488 \text { (1973). }\end{array}$ & $\begin{array}{l}\text { Takings, lessee owner of } \\
\text { condemned lands was not } \\
\text { entitled to value added to leased } \\
\text { lands. Dissent disagrees. }\end{array}$ & Takings, conservative \\
\hline $\begin{array}{l}\text { Rosario v. Rockefeller, } 410 \text { U.S. } \\
752 \text { (1973). }\end{array}$ & $\begin{array}{l}\text { New York early registration for } \\
\text { voting in primary is proper. } \\
\text { Dissent finds burden on vote } \\
\text { excessive. }\end{array}$ & Voting, conservative \\
\hline $\begin{array}{l}\text { Pell v. Procunier, } 417 \text { U.S. } 817 \\
\text { (1974). }\end{array}$ & $\begin{array}{l}\text { California's prohibition against } \\
\text { journalists' requests to interview } \\
\text { specific inmates is proper. } \\
\text { Dissents find it an improper } \\
\text { abridgment of free speech. }\end{array}$ & Criml, conservative \\
\hline $\begin{array}{l}\text { Saxbe v. Wash. Post Co., } 417 \\
\text { U.S. } 843 \text { (1974). }\end{array}$ & $\begin{array}{l}\text { Federal prohibition against } \\
\text { journalists' requests to interview } \\
\text { specific inmates is proper. } \\
\text { Dissents find it an improper } \\
\text { abridgment of free speech. }\end{array}$ & Criml, conservative \\
\hline
\end{tabular}

\section{BLACKMUN-BrenNAN-Douglas-MARSHALl-White (SEVEN O’Clock)}

\begin{tabular}{|l|l|l|}
\hline Sea-Land Servs., Inc. v. & $\begin{array}{l}\text { Admiralty; Longshoreman's } \\
\text { widow can recover in excess of } \\
\text { his recoveries. Dissent disagrees. }\end{array}$ & Tort, liberal \\
\hline $\begin{array}{l}\text { Super Tire Eng'g Co. v. } 573 \text { (1974). } \\
\text { McCorkle, 416 U.S. 115 (1974). }\end{array}$ & $\begin{array}{l}\text { Resolution of objection to New } \\
\text { Jersey benefits for striking } \\
\text { workers not moot despite that } \\
\text { strike was over. Dissent finds it is } \\
\text { moot. }\end{array}$ & Employment, liberal \\
\hline $\begin{array}{l}\text { United States v. ITT Cont'l } \\
\text { Baking Co., 420 U.S. 223 } \\
\text { (1975). }\end{array}$ & $\begin{array}{l}\text { FTC order prohibiting } \\
\text { acquisitions interpreted broadly to } \\
\text { allow daily penalties. Dissent } \\
\text { would interpret narrowly. }\end{array}$ & Admin, liberal \\
\hline
\end{tabular}




\section{Appendix B4: Tables of Stevens Composition Majorities Producing More than Two 5-4 Opinions}

We list the opinions of the United States Supreme Court while its composition is defined by its junior justice being Stevens. The Stevens composition consists of two appointees of Democratic presidents (Marshall and White) and seven appointees of Republican presidents (Blackmun, Brennan, Burger, Powell, Rehnquist, Stevens, and Stewart). We list the majorities as they appear in the corresponding figure in the full-text proceeding clockwise from the nine o'clock position. The name of the case, along with the citation to the United States Reporter, and the year appears in the first column. The second column holds our brief description of the outcome compared to the dissent's position. The third column holds the legal field and the political slant of the majority's position as it arises by juxtaposition to that of the minority. We sort the justices in the majorities by, first, the chief justice, then the associate justices by alphabetical order. One majority initially appeared to have three opinions, but because we dropped one from the sample, the majority also drops from the analysis. The majority is Blackmun, Brennan, Marshall, Stewart, and White. The dropped opinion is Concerned Citizens of Southern Ohio v. Pine Creek Conservancy Dist., 429 U.S. 651 (1977). The majority remands. One dissent would consider the merits, and one would affirm. We drop the case because the dissents are too different to place the majority's political slant.

\section{BRENNAN-MARSHALL-POWELL-STEVENS-STEWART (NiNE O'ClOCK)}

\begin{tabular}{|l|l|l|}
\hline $\begin{array}{l}\text { Hampton v. Mow } \\
\text { Sun Wong, 426 } \\
\text { U.S. 88 (1976). }\end{array}$ & $\begin{array}{l}\text { Blanket prohibition against employment of resident aliens in } \\
\text { the federal civil service violates due process. Dissent sees no } \\
\text { due process protections to obtaining government employment. }\end{array}$ & Social, liberal \\
\hline $\begin{array}{l}\text { Woodson v. North } \\
\text { Carolina, 428 U.S. } \\
\text { 280 (1976). }\end{array}$ & $\begin{array}{l}\text { North Carolina's death sentence law unconstitutional. Dissent } \\
\text { would uphold. }\end{array}$ & Criml, liberal \\
\hline $\begin{array}{l}\text { R o b e r t s v. } \\
\text { Louisiana, 428 } \\
\text { U.S. 325 (1976). }\end{array}$ & $\begin{array}{l}\text { Louisiana death sentence law unconstitutional. Dissent would } \\
\text { uphold. }\end{array}$ & Criml, liberal \\
\hline $\begin{array}{l}\text { B r e w e r v. } \\
\text { Williams, 430 U.S. } \\
\text { 387 (1977). }\end{array}$ & $\begin{array}{l}\text { Tricked confession in police cruiser after reading of Miranda, } \\
\text { deprived suspect of assistance of counsel, triggers exclusionary } \\
\text { rule. Dissent 1 (Burger) would reduce scope of exclusionary } \\
\text { rule; Dissent 2 (White) would not apply it here. }\end{array}$ & CrimPro, liberal \\
\hline $\begin{array}{l}\text { R o b e r t s v . } \\
\text { Louisiana, 431 } \\
\text { U.S. 633 (1977). }\end{array}$ & $\begin{array}{l}\text { Louisiana's mandatory death sentence for killing police } \\
\text { unconstitutional. Dissents disagree. }\end{array}$ & CrimPro, liberal \\
\hline $\begin{array}{l}\text { United States v. } \\
\text { Larionoff, 431 U.S. } \\
864 \text { (1977). }\end{array}$ & $\begin{array}{l}\text { Re-enlisted military entitled to re-enlistment bonus; contrary } \\
\text { rules violate statute. Dissent would uphold contrary rules. }\end{array}$ & Admin, liberal \\
\hline $\begin{array}{l}\text { Th o m s o n v. } \\
\text { United States, 444 } \\
\text { U.S. 248 (1980). }\end{array}$ & $\begin{array}{l}\text { Solicitor General falsely stated he sought federal conviction for } \\
\text { act that was an element of prior state conviction but actually } \\
\text { SG did not seek it and sought reversal; vacates for retrial; } \\
\text { dissent 1 with no opinion, dissent 2 that argument was already } \\
\text { presented. }\end{array}$ & CrimPro, liberal \\
\hline
\end{tabular}




\section{BRENNAN-MARSHALL-POWELL-STEVENS-White (TEN O'CLOCK)}

\begin{tabular}{|l|l|l|}
\hline $\begin{array}{l}\text { C a l i f a n o v. } \\
\text { Goldfarb, 430 U.S. } \\
199 \text { (1977). }\end{array}$ & $\begin{array}{l}\text { Social security limitation on payments to widowers (compared } \\
\text { to widows) violates equal protection. Dissent does not consider } \\
\text { the distinction sufficient for a claim. }\end{array}$ & Social, liberal \\
\hline $\begin{array}{l}\text { Trimble v. Gordon, } \\
430 \text { U.S. 762 } \\
(1977) .\end{array}$ & $\begin{array}{l}\text { Illinois probate law letting illegitimate children inherit intestate } \\
\text { from mothers, not fathers, violates equal protection. Dissent } \\
\text { finds differences and would affirm. }\end{array}$ & Social, liberal \\
\hline $\begin{array}{l}\text { Vitek v. Jones, } 445 \\
\text { U.S. } 480 \text { (1980). }\end{array}$ & $\begin{array}{l}\text { Nebraska inmate has procedural due process right to a hearing } \\
\text { before transport to a mental institution. Dissent finds case } \\
\text { moot. }\end{array}$ & Criml, liberal \\
\hline $\begin{array}{l}\text { Stone v. Graham, } \\
\text { 449 U.S.39(1980). }\end{array}$ & $\begin{array}{l}\text { Kentucky statute requiring ten commandments in all } \\
\text { classrooms violates establishment clause. Dissents would give } \\
\text { plenary hearing, adopt Supreme Court of Kentucky's } \\
\text { reasoning, and accept secular purpose saving statute. }\end{array}$ & Religion, liberal \\
\hline
\end{tabular}

\section{BLACKMUN-BRENNAN-MARSHALL-STEVENS-WHITE (ELEVEN O'CLOCK)}

\begin{tabular}{|c|c|c|}
\hline $\begin{array}{l}\text { Singleton v. Wulff, } \\
428 \text { U.S. } 106 \\
(1976) .\end{array}$ & $\begin{array}{l}\text { Abortion providers challenge Missouri denial of Medicaid for } \\
\text { abortions; plurality: they do have standing, but Cir Ct should } \\
\text { not have reached merits. Dissent } 1 \text { (Stevens) would uphold and } \\
\text { protect impecunious women. Dissent } 2 \text { (Powell, Burger, } \\
\text { Rehnquist, Stewart) would not allow physicians to exercise the } \\
\text { rights of potential patients. }\end{array}$ & Abortion, liberal \\
\hline $\begin{array}{l}\text { C i t y o f } \\
\text { Philadelphia v. } \\
\text { New Jersey, } 430 \\
\text { U.S. } 141 \text { (1977). }\end{array}$ & $\begin{array}{l}\text { Per curiam. Philadelphia wants NJ's prohibition on waste } \\
\text { entering NJ unconstitutional. Majority remands to Supreme } \\
\text { Court of New Jersey to determine whether NJ's statute is } \\
\text { preempted by federal Resource Conservation and Recovery } \\
\text { Act. Dissent believes the act does not preempt NJ's statute and } \\
\text { should reach the merits. }\end{array}$ & $\begin{array}{l}\text { F e d e r a lis m, } \\
\text { liberal }\end{array}$ \\
\hline $\begin{array}{l}\text { Castaneda } v . \\
\text { Partida, } 430 \text { U.S. } \\
482 \text { (1977). }\end{array}$ & $\begin{array}{l}\text { Majority held Jury selection in county where Mexican origin } \\
\text { was } 80 \text { percent but only } 39 \text { percent of veniremen was } \\
\text { discriminatory. Dissent of Stewart with Burger \& Powell } \\
\text { would reverse Court of Appeals (which was upheld) because } \\
\text { District Court was not clearly erroneous. Dissent (Burger with } \\
\text { Powell and Rehnquist) finds majority's position untenable } \\
\text { since it does not know the eligible population stats. Dissent } \\
\text { (Powell with Burger and Rehnquist) find disproportionate } \\
\text { representation was not purposeful and invidious but from } \\
\text { natural causes. }\end{array}$ & CrimPro, liberal \\
\hline $\begin{array}{l}\text { Nyquist v. Mauclet, } \\
432 \text { U.S. } 1 \text { (1977). }\end{array}$ & $\begin{array}{l}\text { Challenge to NY's denial of higher ed benefits to aliens. } \\
\text { Majority held classification was inherently suspect. Dissent of } \\
\text { Burger with Rehnquist \& Powell would not because benefits } \\
\text { denied were not essential to sustain aliens (distinguishing } \\
\text { precedent). Dissent (Powell with Burger and Stewart) because } \\
\text { it is against aliens who prefer to retain foreign citizenship, not } \\
\text { a suspect class. Dissent of Rehnquist with Burger finds state } \\
\text { does not discriminate because alien who declares intent to stay } \\
\text { avoids the disparate treatment. }\end{array}$ & Social, liberal \\
\hline
\end{tabular}




\begin{tabular}{|c|c|c|}
\hline $\begin{array}{l}\text { Bates v. State Bar } \\
\text { of Ariz., } 433 \text { U.S. } \\
350 \text { (1977). }\end{array}$ & $\begin{array}{l}\text { Attorney advertisement protected by First Amendment } \\
\text { (conservative by liberal majority). Burger dissent: Change } \\
\text { harmful to those the ad ban would protect. Rehnquist dissent: } \\
\text { Court demeans First Amendment which is designed for public } \\
\text { speech. Powell dissent with Stewart: Attorney ads inherently } \\
\text { misleading. }\end{array}$ & $\begin{array}{l}\mathrm{S} p \text { e e } \mathrm{c} h \\
\text { conservative }\end{array}$ \\
\hline $\begin{array}{l}\text { Dougherty County, } \\
\text { Georgia, Bd. of } \\
\text { Educ. v. White, } \\
\text { 439 U.S. } 32 \text { (1978). }\end{array}$ & $\begin{array}{l}\text { GA statute requiring unpaid leave for state employees seeking } \\
\text { elected office was subject to prior approval according to the } \\
\text { Voting Rights Act. Dissents find Court's reading of Voting } \\
\text { Rights Act overbroad. }\end{array}$ & Social, liberal \\
\hline $\begin{array}{l}\text { County of Los } \\
\text { Angeles v. Davis, } \\
440 \text { U.S. } 625 \\
(1979) \text {. }\end{array}$ & $\begin{array}{l}\text { Challenge by Hispanics of Los Angeles Fire Department hiring } \\
\text { standards including written test was dismissed as moot. } \\
\text { Dissents against affirmative action suggesting majority's move } \\
\text { was partisan. }\end{array}$ & Social, liberal \\
\hline $\begin{array}{l}\text { Davis v. Passman, } \\
442 \text { U.S. } 228 \\
(1979) \text {. }\end{array}$ & $\begin{array}{l}\text { Fired congressional aide could conceivably have due process } \\
\text { damages claim. Dissent would dismiss to preserve intensely } \\
\text { personal relation with legislative staff. }\end{array}$ & $\begin{array}{l}\text { Employment, } \\
\text { liberal }\end{array}$ \\
\hline $\begin{array}{l}\text { C a } 1 \text { i f a n o v. } \\
\text { Westcott, } 443 \text { U.S. } \\
76 \text { (1979). }\end{array}$ & $\begin{array}{l}\text { Aid to families with dependent children could not have lower } \\
\text { benefits for unemployed parent, if it is the mother. Dissent } \\
\text { agrees with due process violation but would not order remedy } \\
\text { that benefit be paid to all, rather just enjoin payments until } \\
\text { Congress fixes. }\end{array}$ & Social, liberal \\
\hline $\begin{array}{l}\text { Dayton Bd. of } \\
\text { Educ. v. Brinkman, } \\
443 \quad \text { U.S. } 526 \\
(1979) .\end{array}$ & $\begin{array}{l}\text { Majority affirms school integration relief. Dissent } 1 \text { (Stewart } \\
\text { in Columbus Bd. of Educ. v. Penick, } 443 \text { U.S. } 449 \text { (1979)) } \\
\text { would not shift burden and would uphold trial court; Dissent } 2 \\
\text { (Rehnquist with Powell) find segregation to be de facto, not de } \\
\text { jure, and not meriting remedy. }\end{array}$ & Social, liberal \\
\hline $\begin{array}{l}\text { Rose v. Mitchell, } \\
443 \quad \text { U.S. } 545 \\
(1979) \text {. }\end{array}$ & $\begin{array}{l}\text { Majority does not find discrimination in selection of grand jury } \\
\text { foreman but would vacate convictions if it did. Dissents would } \\
\text { not invalidate convictions for grand jury defects. }\end{array}$ & CrimPro, liberal \\
\hline $\begin{array}{l}\text { United States } \\
\text { Parole Comm'n v. } \\
\text { Geraghty, } 445 \text { U.S. } \\
388(1980)\end{array}$ & $\begin{array}{l}\text { Released prisoner's challenge to parole guidelines is not moot, } \\
\text { and he can appeal denial of class certification. Dissent would } \\
\text { not grant such procedural rights. }\end{array}$ & Criml, liberal \\
\hline $\begin{array}{l}\text { Owen v. City of } \\
\text { Independence, Mo., } \\
445 \text { U.S. } 622 \\
(1980) \text {. }\end{array}$ & $\begin{array}{l}\text { Municipality does not have immunity from } 1983 \text { liability for } \\
\text { civil rights violation in firing police chief. Dissent disagrees on } \\
\text { novelty of claim. }\end{array}$ & $\begin{array}{l}\text { Employment, } \\
\text { liberal }\end{array}$ \\
\hline $\begin{array}{l}\text { Clayton v. } \\
\text { Int'l } \\
\text { Union, } 451 \text { U.S. } \\
679(1981) .\end{array}$ & $\begin{array}{l}\text { Employee did not have to exhaust inadequate union remedies } \\
\text { before suing employer and union. Dissent would require } \\
\text { exhaustion. }\end{array}$ & $\begin{array}{l}\text { Employment, } \\
\text { liberal }\end{array}$ \\
\hline
\end{tabular}




\begin{tabular}{|c|c|c|}
\hline $\begin{array}{l}\text { County of Wash., } \\
\text { Or. v. Gunther, } 452 \\
\text { U.S. } 161 \text { (1981). }\end{array}$ & $\begin{array}{l}\text { Female guards at a women's prison have sex discrimination } \\
\text { claim for receiving lower wages than guards of male prison. } \\
\text { Dissent thinks work is not equal. }\end{array}$ & $\begin{array}{l}\text { Employment, } \\
\text { liberal }\end{array}$ \\
\hline $\begin{array}{l}\text { Cal. Medical } \\
\text { Assoc'n v. Fed. } \\
\text { Election Comm'n, } \\
453 \text { U.S. } 182 \\
(1981) \text {. }\end{array}$ & $\begin{array}{l}\text { Plurality upholds campaign contribution limits. Blackmun } \\
\text { concurrence would subject to strict First Amendment review. } \\
\text { Dissent finds majority's construction too burdensome on courts } \\
\text { and far from language of statute. }\end{array}$ & Speech, liberal \\
\hline
\end{tabular}

\section{BURGER-BLACKMUN-REHNQUIST-STEVENS-White (TWELVE O'ClOCK)}

\begin{tabular}{|l|l|l|}
\hline $\begin{array}{l}\text { Cty. Ct. v. Allen, } \\
442 \text { U.S. 140 } \\
(1979) .\end{array}$ & $\begin{array}{l}\text { New York law presumes possession of firearms in car by all } \\
\text { occupants. Majority holds its permissible. Dissent believes } \\
\text { there is a due process violation. }\end{array}$ & $\begin{array}{l}\text { C r i m P r o } \\
\text { conservative }\end{array}$ \\
\hline $\begin{array}{l}\text { United States v. } \\
\text { Raddatz, 447 U.S. } \\
667 \text { (1980). }\end{array}$ & $\begin{array}{l}\text { Magistrate judges may hold evidentiary (suppression) hearings. } \\
\text { Dissent disagrees. }\end{array}$ & $\begin{array}{l}\text { C r i m P r o , } \\
\text { conservative }\end{array}$ \\
\hline $\begin{array}{l}\text { San Diego Gas \& } \\
\text { Elec Co. v. San } \\
\text { Diego, 450 U.S. } \\
621(1981) .\end{array}$ & $\begin{array}{l}\text { Dismisses challenge to California regulatory taking of } \\
\text { property. Dissent would reach merits. Treated as a business } \\
\text { dispute because this is a developer aggregating 412-acre parcel } \\
\text { for nuclear powerplant, liberal because it allows the change in } \\
\text { use from industrial to open/agricultural with no compensation. }\end{array}$ & Business, liberal \\
\hline
\end{tabular}

\section{BURGER-BLACKMUN-POWELL-REHNQUIST-WHITE (ONE O'CLOCK)}

\begin{tabular}{|c|c|c|}
\hline $\begin{array}{l}\text { Roemer v. Bd. of } \\
\text { Public Works, } 426 \\
\text { U.S. } 736 \text { (1976). }\end{array}$ & $\begin{array}{l}\text { MD may fund nonreligious activities in religious colleges. } \\
\text { Dissent } 1 \text { (Brennan with Marshall), "the Act provides for } \\
\text { payment of general subsidies to religious institutions from } \\
\text { public funds and I have heretofore expressed my view that } \\
\text { '[g]eneral subsidies of religious activities would, of course, } \\
\text { constitute impermissible state involvement with religion."' } \\
\text { Dissent } 2 \text { (Stewart) finds theology courses are too religious. } \\
\text { Dissent } 3 \text { agrees with Dissent } 1 \text { but underscores ills of } \\
\text { entanglement. }\end{array}$ & $\begin{array}{l}\mathrm{S} \text { o c i a } 1, \\
\text { conservative }\end{array}$ \\
\hline $\begin{array}{l}\text { L u d w i g } \text { v } \\
\text { Massachusetts, } 427 \\
\text { U.S. } 618 \text { (1976). }\end{array}$ & $\begin{array}{l}\text { Dissent restates as, "The question in this case is whether } \\
\text { Massachusetts may convict a defendant of a crime and } \\
\text { sentence him to prison for a period of five years without a jury } \\
\text { trial" and answers no. }\end{array}$ & $\begin{array}{l}\mathrm{C} \text { r i m P r o, } \\
\text { conservative }\end{array}$ \\
\hline $\begin{array}{l}\text { Codd v. Velger, } \\
429 \text { U.S. } 624 \\
(1977) .\end{array}$ & $\begin{array}{l}\text { Fired police complains cannot find job because of information } \\
\text { about discharge. Dissent } 3 \text { restates as, "I am not persuaded that } \\
\text { a person who claims to have been 'stigmatized' by the State } \\
\text { without being afforded due process need allege that the charge } \\
\text { against him was false in order to state a cause of action under } \\
42 \text { U.S.C. } § 1983 \text { " and would remand. The other dissents agree. }\end{array}$ & $\begin{array}{l}\text { A } \mathrm{d} \mathrm{m} \mathrm{i} \mathrm{n}, \\
\text { conservative }\end{array}$ \\
\hline
\end{tabular}




\begin{tabular}{|c|c|c|}
\hline $\begin{array}{l}\text { Marks v. United } \\
\text { States, } 430 \text { U.S. } \\
188 \text { (1977). }\end{array}$ & $\begin{array}{l}\text { Obscenity defendants should benefit from not having easier } \\
\text { standard from } 1973 \text { opinion apply to them retroactively and } \\
\text { remands. Dissents would not remand but reverse. Because all } \\
\text { justices agree about retroactivity, the disagreement is only } \\
\text { about remand or reversal (if it were about obscenity, it would } \\
\text { be social, liberal). Since remand allows more process that } \\
\text { might still produce a guilty outcome, the division is treated as } \\
\text { about Criminal Procedure and is conservative. }\end{array}$ & $\begin{array}{l}\text { C r i m P r o, } \\
\text { conservative }\end{array}$ \\
\hline $\begin{array}{l}\text { Smith v. United } \\
\text { States, } 431 \text { U.S. } \\
291 \text { (1977). }\end{array}$ & Federal obscenity conviction. Dissents would reverse. & $\begin{array}{l}\mathrm{S} \text { o c i a } 1 \\
\text { conservative }\end{array}$ \\
\hline $\begin{array}{l}\text { Tra in or } \quad \text { v. } \\
\text { Hernandez, } 431 \\
\text { U.S. } 434(1977) \text {. }\end{array}$ & $\begin{array}{l}\text { Federal Court should not enjoin Illinois effort to recover } \\
\text { illegally obtained welfare permits. Dissent } 2 \text { restates, "the } \\
\text { Court holds that an unconstitutional collection procedure may } \\
\text { be used by a state agency, though not by others...." }\end{array}$ & $\begin{array}{l}\text { S o c i a } 1 \\
\text { conservative }\end{array}$ \\
\hline $\begin{array}{l}\text { S p } 1 \text { a w n } \quad \text { v. } \\
\text { California, } 431 \\
\text { U.S. } 595(1977) \text {. }\end{array}$ & $\begin{array}{l}\text { California obscenity conviction upheld. Dissent finds } \\
\text { unconstitutionally overbroad. }\end{array}$ & $\begin{array}{l}\text { S o c i a } 1 \\
\text { conservative }\end{array}$ \\
\hline $\begin{array}{l}\text { Ward v. Illinois, } \\
431 \text { U.S. } 767 \\
(1977) \text {. }\end{array}$ & $\begin{array}{l}\text { Illinois pre-1973 obscenity conviction upheld. Dissent } 1 \text { : } \\
\text { statute is overbroad. Dissent } 2 \text { : the court is wrong in finding } \\
\text { that the Illinois statute complies with the court's obscenity } \\
\text { precedent (Miller, } 413 \text { U.S. 15). }\end{array}$ & $\begin{array}{l}\text { S o c i a } 1 \\
\text { conservative }\end{array}$ \\
\hline $\begin{array}{l}\text { United States v. } \\
\text { New York Tel. Co., } \\
434 \text { U.S. } 159 \\
(1977) .\end{array}$ & $\begin{array}{l}\text { District Court has authority to order Telephone Company to } \\
\text { install surveillance devices. Dissents think the court does not } \\
\text { have this authority. }\end{array}$ & $\begin{array}{l}\text { C r i m P r o, } \\
\text { conservative }\end{array}$ \\
\hline $\begin{array}{l}\text { A m e r i c a } n \\
\text { Broadcasting Cos., } \\
\text { v. Writers Guild of } \\
\text { Am., W., } 437 \text { U.S. } \\
411 \text { (1978). }\end{array}$ & $\begin{array}{l}\text { Dissent: "The Court holds today that a labor union locked in a } \\
\text { direct economic confrontation with an employer is powerless } \\
\text { to impose sanctions on its own members who choose to pledge } \\
\text { their loyalty to the adversary." }\end{array}$ & $\begin{array}{l}\text { Employment, } \\
\text { conservative }\end{array}$ \\
\hline $\begin{array}{l}\text { Bd. of Tr. of Keene } \\
\text { State Coll. v. } \\
\text { Sweeney, } 439 \text { U.S. } \\
24 \text { (1978). }\end{array}$ & $\begin{array}{l}\text { Per Curiam. Remands employer discrimination with lighter } \\
\text { burden of proof on employer. Dissent thinks Circuit Court was } \\
\text { correct. }\end{array}$ & $\begin{array}{l}\text { S o c i a } 1 \\
\text { conservative }\end{array}$ \\
\hline $\begin{array}{l}\text { Dalia v. United } \\
\text { States, } 441 \text { U.S. } \\
238(1979) .\end{array}$ & $\begin{array}{l}\text { Dissent: Order to use electronic surveillance does not also } \\
\text { authorize breaking and entering into the premises in order to } \\
\text { place it and then retrieve it. }\end{array}$ & $\begin{array}{l}\text { C r i m P r o, } \\
\text { conservative }\end{array}$ \\
\hline $\begin{array}{l}\text { Moore v. Sims, } 442 \\
\text { U.S. } 415 \text { (1979). }\end{array}$ & $\begin{array}{l}\text { Parents who lost custody of their children challenge Texas } \\
\text { statutory and judicial scheme, dismissed. Dissent would reach } \\
\text { merits. Considered conservative for being in favor of the state } \\
\text { in federalism question. }\end{array}$ & $\begin{array}{l}\text { Federalis m, } \\
\text { conservative }\end{array}$ \\
\hline $\begin{array}{l}\text { M a c k e y v. } \\
\text { Montrym, } 443 \text { U.S. } \\
1(1979) \text {. }\end{array}$ & $\begin{array}{l}\text { Dissent would require hearing before } 90 \text {-day suspension of } \\
\text { driver's license for refusing to take the breath-analyzer test. }\end{array}$ & $\begin{array}{l}\text { A } \mathrm{d} \mathrm{m} \mathrm{i} \mathrm{n} \text {, } \\
\text { conservative }\end{array}$ \\
\hline
\end{tabular}




\begin{tabular}{|c|c|c|}
\hline $\begin{array}{l}\text { Vance v. Terrazas, } \\
444 \text { U.S. } 252 \\
(1980) \text {. }\end{array}$ & $\begin{array}{l}\text { Dissent } 1 \text { (Marshall) would require more than preponderance } \\
\text { for intent to relinquish US citizenship; Dissent } 2 \text { (Stevens) } \\
\text { would consider statutory standard of oath to foreign } \\
\text { government inappropriate standard. Dissent } 3 \text { (Brennan with } \\
\text { Stewart) does not find the acts constituted a relinquishment. } \\
\text { Social-conservative for disassociating with foreigners. }\end{array}$ & $\begin{array}{l}\text { S o c i a } 1 \text {, } \\
\text { conservative }\end{array}$ \\
\hline $\begin{array}{l}\text { United States v. } \\
\text { Havens, } 446 \text { U.S. } \\
620(1980) .\end{array}$ & $\begin{array}{l}\text { Dissent: "The Court upholds the admission at trial of illegally } \\
\text { seized evidence to impeach a defendant's testimony } \\
\text { deliberately elicited by the Government under the cover of } \\
\text { impeaching an accused who takes the stand in his own behalf." }\end{array}$ & $\begin{array}{l}\mathrm{C} \text { r i m P r o, } \\
\text { conservative }\end{array}$ \\
\hline $\begin{array}{l}\text { Illinois v. Vitale, } \\
447 \text { U.S. } 410 \\
(1980) \text {. }\end{array}$ & $\begin{array}{l}\text { Dissent: Teenager should not face involuntary manslaughter } \\
\text { charge due to double jeopardy after having been convicted of } \\
\text { reckless driving in the same accident. }\end{array}$ & $\begin{array}{l}\text { C r i m P r o, } \\
\text { conservative }\end{array}$ \\
\hline $\begin{array}{l}\text { Del. State College } \\
\text { v. Ricks, } 449 \text { U.S. } \\
250 \text { (1980). }\end{array}$ & $\begin{array}{l}\text { Majority: challenge to refusal of tenure is not timely. Dissent } \\
1 \text { (Stewart with Brennan \& Marshall) denial of tenure was on } \\
\text { date of trustees' decision therefore claim is timely and should } \\
\text { not be dismissed. Dissent } 2 \text { (Stevens) would use actual date of } \\
\text { discharge. }\end{array}$ & $\begin{array}{l}\text { Employment, } \\
\text { conservative }\end{array}$ \\
\hline $\begin{array}{l}\text { Flynt v. Ohio, } 451 \\
\text { U.S. } 619 \text { (1981). }\end{array}$ & $\begin{array}{l}\text { Dismisses challenge to Ohio obscenity charges. Dissent } 1 \\
\text { (Stewart with Brennan \& Marshall) would reverse. Dissent } 2 \\
\text { (Stevens): "the interest in protecting magazine publishers from } \\
\text { being prosecuted criminally because state officials or their } \\
\text { constituents are offended by the content of an admittedly non- } \\
\text { obscene political cartoon is not merely 'an identifiable federal } \\
\text { policy'; it is the kind of interest that motivated the adoption of } \\
\text { the First Amendment." }\end{array}$ & $\begin{array}{l}\text { S o c i a } 1 \text {, } \\
\text { conservative }\end{array}$ \\
\hline
\end{tabular}

\section{BuRGER-POWELL-REHNQUIST-STEWART-WHITE (TWO O'CLOCK)}

\begin{tabular}{|c|c|c|}
\hline $\begin{array}{l}\text { Scott v. Illinois., } \\
440 \text { U.S. } 367 \\
(1979) \text {. }\end{array}$ & $\begin{array}{l}\text { Fined defendant has no right to [free] counsel. Dissents would } \\
\text { grant it. }\end{array}$ & $\begin{array}{l}\text { C r i m P r o, } \\
\text { conservative }\end{array}$ \\
\hline $\begin{array}{l}\text { A m b a c h } \mathrm{v} \text {. } \\
\text { Norwick, } 441 \text { U.S. } \\
68 \text { (1979). }\end{array}$ & $\begin{array}{l}\text { Upholds New York law requiring teachers to be citizens or } \\
\text { intend to become. Dissent disagrees. }\end{array}$ & $\begin{array}{l}\text { S o c i a } 1 \\
\text { conservative }\end{array}$ \\
\hline $\begin{array}{l}\text { Comm. for Pub. } \\
\text { Educ. \& Religious } \\
\text { Liberty v. Regan, } \\
444 \text { U.S. } 646 \\
(1980) .\end{array}$ & $\begin{array}{l}\text { Upholds New York law funding non-public schools. Dissent } 1 \\
\text { shows departure from precedent. Dissent } 2 \text { (Stevens) would } \\
\text { resurrect no funding of religious schools. }\end{array}$ & $\begin{array}{l}\text { S o c i a } 1 \\
\text { conservative }\end{array}$ \\
\hline $\begin{array}{l}\text { Harris v. McRae, } \\
448 \text { U.S. } 297 \\
(1980) \text {. }\end{array}$ & $\begin{array}{l}\text { Challenge to Hyde Amendment restricting Medicaid abortion } \\
\text { funding. Upheld, concurrence (White criticizing dissent of } \\
\text { Stevens) and four dissents. }\end{array}$ & $\begin{array}{l}\text { A b o r t i o n, } \\
\text { conservative }\end{array}$ \\
\hline $\begin{array}{l}\text { Williams v. Zbaraz, } \\
448 \quad \text { U.S. } 358 \\
(1980) \text {. }\end{array}$ & $\begin{array}{l}\text { Upholds Illinois funding of only abortions necessary to save } \\
\text { life of mother. Four dissents. }\end{array}$ & $\begin{array}{l}\text { A b o r tio n, } \\
\text { conservative }\end{array}$ \\
\hline
\end{tabular}




\begin{tabular}{|l|l|l|}
\hline $\begin{array}{l}\text { Diamond v. Diehr, } \\
450 \text { U.S. 175 } \\
(1981) .\end{array}$ & $\begin{array}{l}\text { Grants process patent, conservative for creating more property } \\
\text { rights. }\end{array}$ & $\begin{array}{l}\text { P a t e n t } \\
\text { conservative }\end{array}$ \\
\hline $\begin{array}{l}\text { Lassiter v. Dep't of } \\
\text { Soc. Serv. of } \\
\text { Durham County, N. } \\
\text { Carolina, 452 U.S. } \\
18 \text { (1981). }\end{array}$ & $\begin{array}{l}\text { Termination of mother's parental rights; failure to provide } \\
\text { counsel not violative of due process. Dissent disagrees. }\end{array}$ & $\begin{array}{l}\text { S o c i a 1, } \\
\text { conservative }\end{array}$ \\
\hline $\begin{array}{l}\text { Heffron v. Int'l } \\
\text { Soc'y for Krishna } \\
\text { Consciou sness, } \\
\text { Inc., 452 U.S. 640 } \\
\text { (1981). }\end{array}$ & $\begin{array}{l}\text { Amendment rights of a religious organization requiring the } \\
\text { roving distribution of leaflets. }\end{array}$ & $\begin{array}{l}\text { S p e e c h } \\
\text { conservative }\end{array}$ \\
\hline $\begin{array}{l}\text { L e h m a n v . } \\
\text { Nakshian, } 453 \text { U.S. } \\
156 \text { (1981). }\end{array}$ & $\begin{array}{l}\text { Federal employees making age discrimination claim are not } \\
\text { entitled to jury trial. }\end{array}$ & $\begin{array}{l}\text { C i v P r o }, \\
\text { conservative }\end{array}$ \\
\hline
\end{tabular}

\section{BURGER-BLACKMUN-POWELL-REHNQUIST-STEWART (FOUR O'CLOCK)}

\begin{tabular}{|c|c|c|}
\hline $\begin{array}{l}\text { United States v. } \\
\text { MacCollom, } 426 \\
\text { U.S. } 317 \text { (1976). }\end{array}$ & $\begin{array}{l}\text { Habeas petitioning prisoners do not have a right to a free } \\
\text { transcript. }\end{array}$ & $\begin{array}{l}\text { C r i m P r o, } \\
\text { conservative }\end{array}$ \\
\hline $\begin{array}{l}\text { Nat'l League of } \\
\text { Cities v. Usery, } \\
426 \quad \text { U.S. } 833 \\
(1976) .\end{array}$ & $\begin{array}{l}\text { States are not subject to federal minimum wage for } \\
\text { traditionally state employees (police etc.) because they cannot } \\
\text { fall within the Commerce Clause. Dissents disagree. }\end{array}$ & $\begin{array}{l}\text { Employment, } \\
\text { conservative }\end{array}$ \\
\hline $\begin{array}{l}\text { In g r a h a m v. } \\
\text { Wright, } 430 \text { U.S. } \\
651 \text { (1977). }\end{array}$ & $\begin{array}{l}\text { Florida students are subject to corporal punishment, neither } \\
\text { cruel and unusual, nor hearing needed for due process. Dissent } \\
\text { disagrees. }\end{array}$ & $\begin{array}{l}\text { S o c i a } 1 \text {, } \\
\text { conservative }\end{array}$ \\
\hline $\begin{array}{l}\text { B atterton v. } \\
\text { Francis, } 432 \text { U.S. } \\
416 \text { (1977). }\end{array}$ & $\begin{array}{l}\text { Challenge of denial of aid to families with dependent children; } \\
\text { delegation of the executive meant that the executive's } \\
\text { interpretation rules; regulation valid. Dissent argues statute } \\
\text { sought uniformity of definition of unemployment. }\end{array}$ & $\begin{array}{l}\text { S o c i a } 1 \text {, } \\
\text { conservative }\end{array}$ \\
\hline $\begin{array}{l}\text { Vendo Co. v. } \\
\text { Lektro-Vend Corp., } \\
433 \text { U.S. } 623 \\
(1977) .\end{array}$ & $\begin{array}{l}\text { Challenge of antitrust injunction against enforcement of state } \\
\text { damages remedy for violation of a non-compete clause. } \\
\text { Majority reverses injunction. Dissent would uphold for true } \\
\text { antitrust violation. The judge was the head of the antitrust } \\
\text { division of Department of Justice and head of ABA antitrust } \\
\text { division before bench. Conservative for upholding contractual } \\
\text { arrangement. }\end{array}$ & $\begin{array}{l}\text { B u s i n e s s, } \\
\text { conservative }\end{array}$ \\
\hline $\begin{array}{l}\text { Nixon v. Warner } \\
\text { Communications, } \\
\text { Inc., } 435 \text { U.S. } 589 \\
\text { (1978). }\end{array}$ & $\begin{array}{l}\text { News media did not have First Amendment right to obtain } \\
\text { Nixon tapes from court that got them by subpoena and had to } \\
\text { follow congressional statute about access to presidential } \\
\text { material. Conservative for favoring the president and this } \\
\text { president. Dissent } 1 \text { (White with Brennan) thinks act does not } \\
\text { apply. Dissent } 2 \text { (Marshall) would grant access on public } \\
\text { interest First Amendment. Dissent } 3 \text { (Stevens) would only } \\
\text { reverse trial court for egregious abuse of discretion. }\end{array}$ & $\begin{array}{l}\mathrm{S} \text { p e e c h } \\
\text { conservative }\end{array}$ \\
\hline
\end{tabular}




\begin{tabular}{|c|c|c|}
\hline $\begin{array}{l}\text { United States v. } \\
\text { Scott, } 437 \text { U.S. } 82 \\
\text { (1978). }\end{array}$ & $\begin{array}{l}\text { Allows appeal from dismissals of criminal counts for delay. } \\
\text { Dissent states this changes double jeopardy law, appeals were } \\
\text { disallowed. }\end{array}$ & $\begin{array}{l}\text { C r i m P r o, } \\
\text { conservative }\end{array}$ \\
\hline $\begin{array}{l}\text { Rakas v. Illinois., } \\
439 \text { U.S. } 128 \\
(1978) .\end{array}$ & $\begin{array}{l}\text { Warrantless evidence from getaway car not suppressed because } \\
\text { defendants were mere passengers with no possessory interest } \\
\text { in car or evidence. Dissent opens "The Court today holds that } \\
\text { the Fourth Amendment protects property, not people." }\end{array}$ & $\begin{array}{l}\text { C r i m P r o, } \\
\text { conservative }\end{array}$ \\
\hline $\begin{array}{l}\text { Lalli v. Lalli, } 439 \\
\text { U.S. } 259 \text { (1978). }\end{array}$ & $\begin{array}{l}\text { Plurality upholds NY requirement of filiation during a father's } \\
\text { lifetime as a condition for inheritance by illegitimate child. } \\
\text { Dissent finds unacceptable discrimination against illegitimates. }\end{array}$ & $\begin{array}{l}\text { S o c i a } 1 \text {, } \\
\text { conservative }\end{array}$ \\
\hline $\begin{array}{l}\text { Leis v. Flynt, } 439 \\
\text { U.S. } 438 \text { (1979). }\end{array}$ & $\begin{array}{l}\text { In the Ohio obscenity prosecution of Larry Flynt and Hustler } \\
\text { Magazine, courts refused his out-of-state lawyers to represent } \\
\text { him, and the lawyers claim his prosecution must not proceed } \\
\text { until they receive a hearing for the denial of their right to } \\
\text { represent him. The majority finds no such right, but the dissent } \\
\text { would. Categorized as CrimPro because it is in a criminal } \\
\text { prosecution, as conservative because it avoids the hearing and } \\
\text { moves the prosecution forward. }\end{array}$ & $\begin{array}{l}\text { C r i m P r o, } \\
\text { conservative }\end{array}$ \\
\hline $\begin{array}{l}\text { Detroit Edison Co. } \\
\text { v. NLRB, } 440 \text { U.S. } \\
301 \text { (1979). }\end{array}$ & $\begin{array}{l}\text { NLRB ordered employer to turn over to union the test results } \\
\text { of employees; employer refused absent written authorization, } \\
\text { employer wins. Dissent would give deference to the NLRB to } \\
\text { have balanced the interests correctly when it ordered the } \\
\text { release of the scores. }\end{array}$ & $\begin{array}{l}\text { Employment, } \\
\text { conservative }\end{array}$ \\
\hline $\begin{array}{l}\text { TAMA v. Lewis, } \\
\text { 444 U.S. } 11 \text { (1979). }\end{array}$ & $\begin{array}{l}\text { Investors do not have private right of action under Investment } \\
\text { Advisors Act. Dissent points out court reverses every circuit } \\
\text { court. }\end{array}$ & $\begin{array}{l}\text { B u s i n e s s, } \\
\text { conservative }\end{array}$ \\
\hline $\begin{array}{l}\text { United States v. } \\
\text { Mendenhall, } 446 \\
\text { U.S. } 544(1980) .\end{array}$ & $\begin{array}{l}\text { Drugs found on defendant were not suppressed because she did } \\
\text { not object to search as she was changing planes. Dissent points } \\
\text { out that this is a plurality while a majority do not deny seizure } \\
\text { and a majority do not find adequate grounds for it. }\end{array}$ & $\begin{array}{l}\text { C r i m P r o, } \\
\text { conservative }\end{array}$ \\
\hline $\begin{array}{l}\text { Dawson Chemical } \\
\text { Co. v. Rohm \& } \\
\text { Haas Co., } 448 \text { U.S. } \\
176(1980) .\end{array}$ & $\begin{array}{l}\text { Dissent: "For decades this Court has denied relief from } \\
\text { contributory infringement to patent holders who attempt to } \\
\text { extend their patent monopolies to unpatented materials used in } \\
\text { connection with patented inventions. The Court now refuses to } \\
\text { apply this 'patent misuse' principle in the very area in which } \\
\text { such attempts to restrain competition are most likely to be } \\
\text { successful. The Court holds exempt from the patent misuse } \\
\text { doctrine a patent holder's refusal to license others to use a } \\
\text { patented process unless they purchase from him an unpatented } \\
\text { product that has no substantial use except in the patented } \\
\text { process." }\end{array}$ & $\begin{array}{l}\mathrm{P} \text { a } \mathrm{t} \text { e } \mathrm{nt}, \\
\text { conservative }\end{array}$ \\
\hline $\begin{array}{l}\text { United States v. } \\
\text { DiFrancesco, } 449 \\
\text { U.S. } 117(1980) .\end{array}$ & $\begin{array}{l}\text { Government's right to appeal sentence under the Organized } \\
\text { Crime Control Act does not violate double jeopardy. Dissent } \\
\text { disagrees. }\end{array}$ & $\begin{array}{l}\text { C r i m P r o, } \\
\text { conservative }\end{array}$ \\
\hline $\begin{array}{l}\text { Michael M. v. } \\
\text { Superior Court. of } \\
\text { Sonoma Cnty., } 450 \\
\text { U.S. } 464 \text { (1981). }\end{array}$ & $\begin{array}{l}\text { Statutory rape law of California does not discriminate against } \\
\text { men. Dissent } 1 \text { finds the classification unconstitutional. Dissent } \\
2 \text { (Stevens) finds influence on conduct minimal and would not } \\
\text { uphold ban. }\end{array}$ & $\begin{array}{l}\text { S o c i a } 1 \text {, } \\
\text { conservative }\end{array}$ \\
\hline
\end{tabular}




\section{Burger-PowelL-REHNQuist-STEVEnS-STEWART (FIVE O'ClOCK)}

\begin{tabular}{|c|c|c|}
\hline $\begin{array}{l}\text { New York Civil } \\
\text { Serv. Comm'n v. } \\
\text { Snead, } 425 \text { U.S. } \\
457(1976) .\end{array}$ & $\begin{array}{l}\text { Per curiam. Since the statute never properly applied to } \\
\text { complainant, therefore the court refuses to decide its } \\
\text { constitutionality, state wins against employee. Dissent would } \\
\text { vacate without oral argument. }\end{array}$ & $\begin{array}{l}\text { A } \mathrm{d} \mathrm{m} \mathrm{i} \mathrm{n}, \\
\text { conservative }\end{array}$ \\
\hline $\begin{array}{l}\text { Bishop v. Wood, } \\
426 \text { U.S. } 341 \\
(1976) \text {. }\end{array}$ & $\begin{array}{l}\text { Fired police officer claims due process violations against city. } \\
\text { Majority finds due process does not require hearing. Dissents } \\
\text { would require hearing before hiring. }\end{array}$ & $\begin{array}{l}\text { A } \mathrm{d} \mathrm{m} \mathrm{i} \mathrm{n}, \\
\text { conservative }\end{array}$ \\
\hline $\begin{array}{l}\text { NLRB v. Catholic } \\
\text { Bishop of Chicago, } \\
440 \text { U.S. } 490 \\
(1979) \text {. }\end{array}$ & $\begin{array}{l}\text { Church schools are not subject to NLRB due to First } \\
\text { Amendment. Dissent: no. Labor and conservative for leniency } \\
\text { on a class of employers. }\end{array}$ & $\begin{array}{l}\text { Employment, } \\
\text { conservative }\end{array}$ \\
\hline $\begin{array}{l}\text { Parham v. Hughes, } \\
441 \quad \text { U.S. } 347 \\
(1979) \text {. }\end{array}$ & $\begin{array}{l}\text { Georgia's statute barring illegitimate fathers from recovery in } \\
\text { wrongful death of child upheld. Dissent: facial discrimination } \\
\text { by sex. Business conservative if central idea is liability or } \\
\text { social conservative if central idea is inducement of traditional } \\
\text { family. Latter seems closer to court's thinking. }\end{array}$ & $\begin{array}{l}\mathrm{S} \text { o c i a } 1, \\
\text { conservative }\end{array}$ \\
\hline $\begin{array}{l}\text { Califano v. Boles, } \\
443 \text { U.S. } 282 \\
(1979)\end{array}$ & $\begin{array}{l}\text { Majority upholds reduced benefits to mothers who did not wed } \\
\text { their children's fathers under social security. Dissent sees } \\
\text { discrimination against unmarried parents. }\end{array}$ & $\begin{array}{l}\text { S o c i a } 1, \\
\text { conservative }\end{array}$ \\
\hline $\begin{array}{l}\text { Gannett Co. , v. } \\
\text { Depasquale, } 443 \\
\text { U.S. } 368(1979) \text {. }\end{array}$ & $\begin{array}{l}\text { Plurality upholds exclusion of press from pretrial hearing. } \\
\text { Dissent finds majority's resulting rule too easy for the parties } \\
\text { and the judge. }\end{array}$ & $\begin{array}{l}\mathrm{C} \mathrm{r} \mathrm{i} \mathrm{m} \mathrm{P} \mathrm{r} \mathrm{o,} \\
\text { conservative }\end{array}$ \\
\hline $\begin{array}{l}\text { NLRB v. Yeshiva } \\
\text { Univ., } 444 \text { U.S. } \\
672(1980) .\end{array}$ & $\begin{array}{l}\text { University professors are not entitled to collective labor } \\
\text { bargaining for being managers. Dissent would follow the } \\
\text { interpretation of the NLRB and allow professors to unionize. }\end{array}$ & $\begin{array}{l}\text { Employment, } \\
\text { conservative }\end{array}$ \\
\hline $\begin{array}{l}\text { Indus. Union Dep't } \\
\text { v. Am. Petroleum } \\
\text { Inst., } 448 \text { U.S. } 607 \\
(1980) .\end{array}$ & $\begin{array}{l}\text { Plurality invalidates OSHA toughening of benzene emissions } \\
\text { standard. Dissent: "The plurality ignores the plain meaning of } \\
\text { the Occupational Safety and Health Act of } 1970 \text { in order to } \\
\text { bring the authority of the Secretary of Labor in line with the } \\
\text { plurality's own views of proper regulatory policy." }\end{array}$ & $\begin{array}{l}\text { A d } \mathrm{m} \mathrm{i} \mathrm{n} \text {, } \\
\text { conservative }\end{array}$ \\
\hline $\begin{array}{l}\text { Ball v. James, } 451 \\
\text { U.S. } 355 \text { (1981). }\end{array}$ & $\begin{array}{l}\text { Dissent: "In concluding that the District's 'one-acre, one-vote' } \\
\text { scheme is constitutional, the Court misapplies the limited } \\
\text { exception recognized in Salyer Land . . , on the strained logic } \\
\text { that the provision of water and electricity to several hundred } \\
\text { thousand citizens is a 'peculiarly narrow function."' }\end{array}$ & $\begin{array}{l}\mathrm{S} \text { o c i a } 1, \\
\text { conservative }\end{array}$ \\
\hline
\end{tabular}

\section{BURGER-BLACKMUN-REHNQUist-STEWART-White (SiX O’ClOCK)}

\begin{tabular}{|l|l|l|}
\hline Buffalo Forge Co. & Majority would not grant employer injunction against & Employment, \\
v . U n i t e d & sympathy strike. Dissent (Stevens with all) thinks the employer & liberal \\
Steelworkers of & may be entitled to an injunction. & \\
America, 428 U.S. & & \\
397 (1976). & & \\
\hline
\end{tabular}




\begin{tabular}{|c|c|c|}
\hline $\begin{array}{l}\text { Zacchini } \\
\text { Scripps-Howard } \\
\text { Broadcasting Co., } \\
433 \text { U.S. } 562 \\
(1977) \text {. }\end{array}$ & $\begin{array}{l}\text { Ohio Supreme Court gives newscast First Amendment right to } \\
\text { air tape of human cannonball; majority: entire act is not } \\
\text { protected as news. Dissent } 1 \text { (Powell, Brennan, \& Marshall) } \\
\text { consider it proper news matter. Dissent } 2 \text { (Stevens) would ask } \\
\text { Ohio Supreme Court to clarify as it looks too much about right } \\
\text { of publicity relating to tort doctrines. Conservative for limiting } \\
\text { speech and protecting creator's rights. }\end{array}$ & $\begin{array}{l}\mathrm{S} \text { p e e c h } \\
\text { conservative }\end{array}$ \\
\hline $\begin{array}{l}\text { Bell v. Wolfish, } \\
441 \text { U.S. } 520 \\
(1979) \text {. }\end{array}$ & $\begin{array}{l}\text { Pretrial detainees' challenge of practices at detention center } \\
\text { denied. Dissents find majority far too permissive of intrusions } \\
\text { upon the person of presumed innocent. }\end{array}$ & $\begin{array}{l}\mathrm{C} \text { r i } \mathrm{m} 1 \text {, } \\
\text { conservative }\end{array}$ \\
\hline $\begin{array}{l}\text { Greenholtz } \mathrm{v} . \\
\text { Inmates of the Neb. } \\
\text { Penal \& Corr. } \\
\text { Complex, } 442 \text { U.S. } \\
1 \text { (1979). }\end{array}$ & $\begin{array}{l}\text { Nebraska's parole process complied with due process. Dissent } \\
1 \text { (Powell) would require the } 72 \text {-hour notice of District Court. } \\
\text { Dissent } 2 \text { (Marshall, Brennan, \& Stevens) finds liberty interest } \\
\text { deserving broader protection. }\end{array}$ & $\begin{array}{l}\text { C } \mathrm{r} \text { i } \mathrm{m} 1 \text {, } \\
\text { conservative }\end{array}$ \\
\hline $\begin{array}{l}\text { Fare v. Michael C., } \\
442 \text { U.S. } 707 \\
(1979) \text {. }\end{array}$ & $\begin{array}{l}\text { Juvenile who asked for probation officer but not attorney is } \\
\text { considered to have waived rights and statements are } \\
\text { admissible. }\end{array}$ & $\begin{array}{l}\mathrm{C} \text { r i m P r o, } \\
\text { conservative }\end{array}$ \\
\hline $\begin{array}{l}\text { Rummel v. Estelle, } \\
445 \text { U.S. } 263 \\
(1980) \text {. }\end{array}$ & $\begin{array}{l}\text { Texas three strikes imposing life on } \$ 120 \text { fraud not cruel and } \\
\text { unusual. }\end{array}$ & $\begin{array}{l}\mathrm{C} r \mathrm{i} \mathrm{m} \mathrm{l}, \\
\text { conservative }\end{array}$ \\
\hline $\begin{array}{l}\text { Schweiker v. } \\
\text { Wilson, } 450 \text { U.S. } \\
221(1981) \text {. }\end{array}$ & $\begin{array}{l}\text { Mentally ill under Medicare are not protected group, rational } \\
\text { basis applies and state can reduce discretionary funding. }\end{array}$ & $\begin{array}{l}\mathrm{S} \text { o c i a } 1 \\
\text { conservative }\end{array}$ \\
\hline
\end{tabular}

\section{BlaCKMUN-BRENNAN-MARSHALL-STEVENS-STEWART (SEVEN O'ClOCK)}

\begin{tabular}{|l|l|l|}
\hline $\begin{array}{l}\text { Vance v. Universal } \\
\text { Amusement Co., } \\
\text { Inc., } 445 \text { U.S. } 308 \\
(1980) .\end{array}$ & $\begin{array}{l}\text { Texas block on display of potentially obscene movies till } \\
\text { determination to restrictive. Dissents would not grant } \\
\text { protection. }\end{array}$ & Social, liberal \\
\hline $\begin{array}{l}\text { Baldasar v. Ill., } 446 \\
\text { U.S. 222 (1980). }\end{array}$ & $\begin{array}{l}\text { An uncounseled misdemeanor conviction may not be used } \\
\text { under an enhanced penalty statute to convert a subsequent } \\
\text { misdemeanor into a felony. Dissent (Powell, White, \& } \\
\text { Rehnquist), uncounseled misdemeanors are valid. }\end{array}$ & CrimPro, liberal \\
\hline $\begin{array}{l}\text { Bullington v. Mo., } \\
\text { 451 U.S. 430 } \\
(1981) .\end{array}$ & $\begin{array}{l}\text { Reversed life sentence precludes death sentence on retrial in } \\
\text { Missouri. Dissent (Powell with all) would allow death. }\end{array}$ & CrimPro, liberal \\
\hline
\end{tabular}

\section{BLACKMUN-BRENNAN-MARSHALL-POWELL-White (EIGHT O'ClOCK)}

\begin{tabular}{|l|l|l|}
\hline $\begin{array}{l}\text { United States v. } \\
\text { Lasalle National } \\
\text { Bank, 437 U.S. } 298 \\
\text { (1978). }\end{array}$ & $\begin{array}{l}\text { IRS summons to bank was not in bad faith. Dissent (Stewart } \\
\text { with all) would even more clearly favor criminal prosecutions. }\end{array}$ & Tax, liberal \\
\hline $\begin{array}{l}\text { Regents of the } \\
\text { University of }\end{array}$ & $\begin{array}{l}\text { Affirmative action; plurality in favor of potential but against } \\
\text { actual practice. Dissent (Stevens, Burger, Stewart, \& }\end{array}$ & Social, liberal \\
California v. & Rehnquist) is against any affirmative action. & \\
Bakke, 438 U.S. & & \\
265 (1978). & & \\
\hline
\end{tabular}




\begin{tabular}{|l|l|l|}
\hline $\begin{array}{l}\text { Butz v. Economou, } \\
438 \text { U.S. } 478 \\
(1978) .\end{array}$ & $\begin{array}{l}\text { Majority grants qualified immunity to federal officials. Dissent } \\
\text { (Rehnquist with all) would grant stronger immunity. }\end{array}$ & Admin, liberal \\
\hline $\begin{array}{l}\text { C a b a n v . } \\
\text { Mohammed, 441 }\end{array}$ & $\begin{array}{l}\text { Unwed fathers, under NY law, less able to block adoptions } \\
\text { than mothers, reversed. Dissents would give fathers fewer } \\
\text { protections; dissenters considered conservative for adhering to } \\
\text { older gender stereotypes. }\end{array}$ & Social, liberal \\
\hline $\begin{array}{l}\text { NLRB v. Int'l } \\
\text { Longshoremen's } \\
\text { Assn., 447 U.S. } \\
490(1980) .\end{array}$ & $\begin{array}{l}\text { Labor dispute over treatment of maritime containers (new } \\
\text { technology). NLRB issued rules they were not part of } \\
\text { longshoremen's work, reversed. Dissent (Burger with all) sees } \\
\text { the ILA trying to usurp the new technology. }\end{array}$ & liberal \\
\hline
\end{tabular}

\section{Appendix B5: Tables of O'Connor Composition Majorities Producing More than Two 5-4 Opinions}

We list the opinions of the United States Supreme Court while its composition is defined by its junior justice being O'Connor. The O'Connor composition consists of two appointees of Democratic presidents (Marshall and White) and seven appointees of Republican presidents (Blackmun, Brennan, Burger, O'Connor, Powell, Rehnquist, and Stevens). We list the majorities as they appear in the corresponding figure in the full-text proceeding clockwise from the nine o'clock position. The name of the case, along with the citation to the United States Reporter, and the year appears in the first column. The second column holds our brief description of the outcome compared to the dissent's position. The third column holds the legal field and the political slant of the majority's position as it arises by juxtaposition to that of the minority. We sort the justices in the majorities by, first, the chief justice, then the associate justices by alphabetical order.

\section{Blackmun-BrenNaN-Marshall-SteVens-White (Nine O'ClOCK)}

\begin{tabular}{|c|c|c|}
\hline $\begin{array}{l}\text { N L R B V . } \\
\text { Hendricks Cty. } \\
\text { R u ra } 1 \quad \text { E } 1 \text { e c. } \\
\text { Membership Corp., } \\
454 \text { U.S. } 170 \\
(1981) .\end{array}$ & $\begin{array}{l}\text { Dissent would exclude from the NLRA the confidential } \\
\text { secretary. }\end{array}$ & $\begin{array}{l}\text { Employment, } \\
\text { liberal }\end{array}$ \\
\hline $\begin{array}{l}\text { C h a r } 1 \text { e s D . } \\
\text { Bonanno Linen } \\
\text { Serv., Inc., v. } \\
\text { N.L.R.B., } 454 \text { U.S. } \\
404 \text { (1982). }\end{array}$ & $\begin{array}{l}\text { Dissent } 1 \text { (Burger with Rehnquist), would allow employer to } \\
\text { withdraw from multi-employer bargaining agreement after } \\
\text { impasse. Dissent } 2 \text { (O'Connor with Powell) finds majority and } \\
\text { Dissent } 1 \text { too inflexible and would have the N.L.R.B. make } \\
\text { more findings. }\end{array}$ & $\begin{array}{l}\text { Employment, } \\
\text { liberal }\end{array}$ \\
\hline $\begin{array}{l}\text { Merrill Lynch, } \\
\text { Pierce, Fenner \& } \\
\text { Smith, Inc., v. } \\
\text { Curran, } 456 \text { U.S. } \\
353 \text { (1982). }\end{array}$ & $\begin{array}{l}\text { Majority finds private right of action under Commodities } \\
\text { Exchange Act. Dissent would not. }\end{array}$ & Business, liberal \\
\hline
\end{tabular}




\begin{tabular}{|c|c|c|}
\hline $\begin{array}{l}\text { F.E.R.C. v. Miss., } \\
456 \quad \text { U.S. } 742 \\
(1982) .\end{array}$ & $\begin{array}{l}\text { Majority upholds Public Utility Regulatory Policies Act. } \\
\text { Dissents would strike down much of it. Dissent } 1 \text { (Powell) } \\
\text { would only strike the provisions mandating procedure. }\end{array}$ & Business, libera \\
\hline $\begin{array}{l}\text { Conn. v. Teal, } 457 \\
\text { U.S. } 440 \text { (1982). }\end{array}$ & $\begin{array}{l}\text { Connecticut's written exams for public employees' promotions } \\
\text { had racial disparate impact. Dissent (Powell with all) disagrees. }\end{array}$ & Social, liberal \\
\hline $\begin{array}{l}\text { Foremost Ins. Co. } \\
\text { v. Richardson, } 457 \\
\text { U.S. } 668 \text { (1982). }\end{array}$ & $\begin{array}{l}\text { Collision of pleasure boats on river did confer admiralty } \\
\text { jurisdiction. Dissent (Powell with all) rues erosion of } \\
\text { federalism. }\end{array}$ & Business, libera \\
\hline $\begin{array}{l}\text { Taylor v. Ala., } 457 \\
\text { U.S. } 687 \text { (1982). }\end{array}$ & $\begin{array}{l}\text { Confession after illegal arrest suppressed. Dissent (O'Connor } \\
\text { with all) would not. }\end{array}$ & CrimPro, liberal \\
\hline $\begin{array}{l}\text { Bd. of Educ., } \\
\text { Island Trees Union } \\
\text { Free Sch. Dist. No. } \\
26 \text { v. Pico, } 457 \\
\text { U.S. } 853 \text { (1982). }\end{array}$ & $\begin{array}{l}\text { Plurality: School Board may not remove books it does not like } \\
\text { from library. Dissent } 1 \text { (Burger with all), calls holding a "lavish } \\
\text { expansion" where the court gets "perilously close to becoming } \\
\text { a 'super censor' of school board library decisions." Dissent } 2 \\
\text { (Powell) lists quotes from the "nine vulgar or racist text } \\
\text { books," like Slaughterhouse Five, "'Get out of the road, you } \\
\text { dumb motherfucker.' The last word was still a novelty in the } \\
\text { speech of white people in 1944. It was fresh and astonishing to } \\
\text { Billy, who had never fucked anybody . .." Dissent } 3 \\
\text { (Rehnquist with Burger \& Powell) states "It is true that the } \\
\text { Court has recognized a limited version of that right in other } \\
\text { settings, and Justice Brennan quotes language from five such } \\
\text { decisions and one of his own concurring opinions in order to } \\
\text { demonstrate the viability of the right-to-receive doctrine." } \\
\text { Dissent } 4 \text { (O'Connor), "If the school board can set the } \\
\text { curriculum, select teachers, and determine initially what books } \\
\text { to purchase for the school library, it surely can decide which } \\
\text { books to discontinue or remove from the school library." The } \\
\text { topic could be First Amendment or Social, however, because } \\
\text { it does not influence speech, it is categorized as social. }\end{array}$ & Social, liberal \\
\hline $\begin{array}{l}\text { L u g a r } \mathrm{v} . \\
\text { Edmondson Oil } \\
\text { Co., } 457 \text { U.S. } 922 \\
\text { (1982). }\end{array}$ & $\begin{array}{l}\text { Dissent (Burger) states “... it cannot be said that the actions of } \\
\text { the named respondents are fairly attributable to the State. } \\
\text { Respondents did no more than invoke a presumptively valid } \\
\text { state prejudgment attachment procedure available to all." }\end{array}$ & Business, libera \\
\hline $\begin{array}{l}\text { Wash. v. Seattle } \\
\text { Sch. Dist. No. } 1 \text {, } \\
458 \text { U.S. } 457 \\
(1982) \text {. }\end{array}$ & $\begin{array}{l}\text { Majority invalidates WA statute requiring pupils to go to the } \\
\text { nearest school except for desegregation. Dissent (Powell with } \\
\text { all) "In the absence of a constitutional violation, no decision of } \\
\text { this Court compels a school district to adopt or maintain a } \\
\text { mandatory busing program for racial integration." }\end{array}$ & Social, liberal \\
\hline $\begin{array}{l}\text { Enmund v. } \text { Fla., } \\
458 \text { U.S. } 782 \\
(1982) .\end{array}$ & $\begin{array}{l}\text { Majority reverses death penalty for aider who did not kill. } \\
\text { Dissent (O'Connor), “. . . today's holding interferes with state } \\
\text { criteria for assessing legal guilt by recasting intent as a matter } \\
\text { of federal constitutional law.” }\end{array}$ & Criml, liberal \\
\hline
\end{tabular}




\begin{tabular}{|c|c|c|}
\hline $\begin{array}{l}\text { Conn. v. Johnson, } \\
460 \text { U.S. } 73 \text { (1983). }\end{array}$ & $\begin{array}{l}\text { Dissent } 2 \text { (Powell with all) would consider error harmless and } \\
\text { not suppress stating: "Today a plurality of this Court finds that } \\
\text { an instruction given in violation of Sandstrom } v \text {. Montana, } 442 \\
\text { U.S. } 510 \text { (1979), cannot be considered harmless except in } \\
\text { certain 'rare situations.'”" }\end{array}$ & CrimPro, liberal \\
\hline $\begin{array}{l}\text { E.E.O.C. v. Wyo., } \\
460 \quad \text { U.S. } 226 \\
(1983) .\end{array}$ & $\begin{array}{l}\text { Majority: State having } 55 \text { years as the retirement age of game } \\
\text { warden violates age discrimination statute. Dissent (Burger } \\
\text { with all), "The Court decides today that Congress may dictate } \\
\text { to the states, and their political subdivisions, detailed standards } \\
\text { governing the selection of state employees, including those } \\
\text { charged with protecting people and homes from crimes and } \\
\text { fires. Although the opinion reads the Constitution to allow } \\
\text { Congress to usurp this fundamental state function, I have } \\
\text { reexamined that document and I fail to see where it grants to } \\
\text { the national government the power to impose such strictures on } \\
\text { the states either expressly or by implication." Dissent } 2 \text { (Powell } \\
\text { with O'Connor), “. . . write separately to record a personal } \\
\text { dissent from Justice Stevens' novel view of our Nation's } \\
\text { history." }\end{array}$ & $\begin{array}{l}\text { Employment, } \\
\text { liberal }\end{array}$ \\
\hline $\begin{array}{l}\text { Smith v. Wade, } \\
\text { 461 U.S. } 30 \text { (1983). }\end{array}$ & $\begin{array}{l}\text { Majority upholds award of punitive damages for section } 1983 \\
\text { violations (in reformatory). Dissent } 1 \text { (Rehnquist with Burger } \\
\& \text { Powell), would have higher hurdle. Dissent } 2 \text { (O'Connor) } \\
\text { disagrees with both and would not award punitive damages for } \\
\text { recklessness. This is categorized as being about conditions of } \\
\text { punishment because of the setting. }\end{array}$ & Criml, liberal \\
\hline $\begin{array}{l}\text { U.S. v. Sells Eng'g, } \\
\text { Inc., } 463 \text { U.S. } 418 \\
(1983) .\end{array}$ & $\begin{array}{l}\text { Dissent (Burger with all): "The Court today holds that } \\
\text { attorneys within the Department of Justice who are not } \\
\text { assigned to the grand jury investigation or prosecution must } \\
\text { seek a court order on a showing of particularized need in order } \\
\text { to obtain access, for the purpose of preparing a civil suit, to } \\
\text { grand jury materials already in the Government's possession. } \\
\text { In my view, this holding is contrary not only to the clear } \\
\text { language but also to the history of Rule 6(e)(3)(A)(i) of the } \\
\text { Federal Rules of Criminal Procedure." }\end{array}$ & CrimPro, liberal \\
\hline $\begin{array}{l}\text { N.L.R.B. v. City } \\
\text { Disposal Sys., Inc., } \\
465 \quad \text { U.S. } 822 \\
(1984) .\end{array}$ & $\begin{array}{l}\text { Majority: The refusal to work with damaged equipment is an } \\
\text { exercise of collective bargaining right. Dissent (O'Connor with } \\
\text { all), argues that it is not. }\end{array}$ & $\begin{array}{l}\text { Employment, } \\
\text { liberal }\end{array}$ \\
\hline $\begin{array}{l}\text { Pulliam v. Allen, } \\
466 \text { U.S. } 522 \\
(1984) .\end{array}$ & $\begin{array}{l}\text { Majority: May not require bond and incarcerate for non- } \\
\text { incarcerable offenses. Dissent (Powell with all), "The Court } \\
\text { today reaffirms the rule that judges are immune from suits for } \\
\text { damages, but holds that they may be sued for injunctive and } \\
\text { declaratory relief and held personally liable for money } \\
\text { judgments in the form of costs and attorney's fees merely on } \\
\text { the basis of erroneous judicial decisions. The basis for the } \\
\text { Court's distinction finds no support in common law and in } \\
\text { effect eviscerates the doctrine of judicial immunity that the } \\
\text { common law so long has accepted as absolute." Categorized as } \\
\text { social because incarceration for petty offenses is a problem for } \\
\text { the poor. }\end{array}$ & Social, liberal \\
\hline
\end{tabular}




\begin{tabular}{|c|c|c|}
\hline $\begin{array}{l}\text { Sec'y of State of } \\
\text { Md. v. Joseph H. } \\
\text { Munson Co., } 467 \\
\text { U.S. } 947 \text { (1984). }\end{array}$ & $\begin{array}{l}\text { Majority invalidates Maryland statute limiting fundraiser fees } \\
\text { to } 25 \text { percent. Dissent (Rehnquist with all), “. . . given the } \\
\text { extensive legitimate application of this statute, both to } \\
\text { fundraising expenses not attributable to public education or } \\
\text { advocacy and to the fees charged by professional fundraisers } \\
\text { who, like Munson, are not themselves engaged in advocating } \\
\text { any causes, I see no basis for concluding that the Maryland } \\
\text { statute is substantially overbroad. Nor does the Court offer any } \\
\text { reason to so believe." }\end{array}$ & Speech, liberal \\
\hline $\begin{array}{l}\text { Garcia v. San } \\
\text { Antonio Metro. } \\
\text { Transit Auth., } 469 \\
\text { U.S. } 528 \text { (1985). }\end{array}$ & $\begin{array}{l}\text { Majority applies minimum wage to government employees (all } \\
\text { functions, including governmental). Dissents disagree. }\end{array}$ & $\begin{array}{l}\text { Employment, } \\
\text { liberal }\end{array}$ \\
\hline $\begin{array}{l}\text { Francis v. Franklin, } \\
471 \quad \text { U.S. } 307 \\
(1985) .\end{array}$ & $\begin{array}{l}\text { Majority grants challenge to conviction on mandatory intent } \\
\text { instruction. Dissent } 1 \text { (Powell) does not see irrefutable } \\
\text { presumption. Dissent } 2 \text { (Rehnquist with Burger \& O'Connor): } \\
\text { "The conviction is set aside because this Court concludes that } \\
\text { one or two sentences out of several pages of instructions given } \\
\text { by the judge to the jury could be read as allowing the jury to } \\
\text { return a guilty verdict in the absence of proof establishing } \\
\text { every statutory element of the crime beyond a reasonable } \\
\text { doubt. The Court reaches this result even though the judge } \\
\text { admonished the jury at least four separate times that they could } \\
\text { convict only if they found guilt beyond a reasonable doubt." }\end{array}$ & CrimPro, liberal \\
\hline
\end{tabular}

\section{BLACKMUN-BRENNAN-MARSHALL-POWELL-STEVENS (TEN O'ClOCK)}

\begin{tabular}{|c|c|c|}
\hline $\begin{array}{l}\text { S a n to s k y v. } \\
\text { Kramer, } 455 \text { U.S. } \\
745 \text { (1982). }\end{array}$ & $\begin{array}{l}\text { Majority: New York should not use preponderance but clear } \\
\text { and convincing as standard for terminating parental rights for } \\
\text { neglect. Dissent (Rehnquist with all) argues that federal courts } \\
\text { should stay out of domestic relations leaving to traditionally } \\
\text { state jurisdiction. }\end{array}$ & Social, liberal \\
\hline $\begin{array}{l}\text { Larson v. Valente, } \\
456 \quad \text { U.S. } 228 \\
(1982) .\end{array}$ & $\begin{array}{l}\text { Invalidating statute exempting from registration only churches } \\
\text { that raise more than } 50 \text { percent from members. Dissent } 1 \\
\text { (White with Rehnquist), “. . . if the State determines that its } \\
\text { interest in preventing fraud does not extend to those who do } \\
\text { not raise a majority of their funds from the public, its interest } \\
\text { in imposing the requirement on others is not thereby reduced } \\
\text { in the least." Dissent } 2 \text { (Rehnquist with Burger, White, and } \\
\text { O'Connor) finds no standing. }\end{array}$ & Religion, liberal \\
\hline $\begin{array}{l}\text { Plyler v. Doe, } 457 \\
\text { U.S. } 202 \text { (1982). }\end{array}$ & $\begin{array}{l}\text { Majority (with concurrences) strikes down Texas refusal to } \\
\text { fund illegal alien children's education. Dissent (Burger with } \\
\text { all) thinks the court usurps political authority. }\end{array}$ & Social, liberal \\
\hline $\begin{array}{l}\text { U.S. v. Johnson, } \\
457 \text { U.S. } 537 \\
(1982) \text {. }\end{array}$ & $\begin{array}{l}\text { Majority applies retroactively Fourth Amendment } \\
\text { interpretations on non-final proceedings. Dissent (White with } \\
\text { all) rues expansion of retroactivity doctrine. }\end{array}$ & CrimPro, liberal \\
\hline
\end{tabular}




\begin{tabular}{|c|c|c|}
\hline $\begin{array}{lr}\text { Solem v. } & \text { Helm, } \\
463 \text { U.S. } & 277 \\
(1983) . & \end{array}$ & $\begin{array}{l}\text { A challenge to South Dakota recidivist statute enhancing five- } \\
\text { year-max felony to life was held to be cruel and unusual. } \\
\text { Dissent (Burger with all), "... today the Court blithely discards } \\
\text { any concept of stare decisis, trespasses gravely on the authority } \\
\text { of the States, and distorts the concept of proportionality of } \\
\text { punishment." "[C]urious business for this Court to so far } \\
\text { intrude into the administration of criminal justice to say that a } \\
\text { state legislature is barred by the Constitution from identifying } \\
\text { its habitual criminals and removing them from the streets." }\end{array}$ & Criml, liberal \\
\hline $\begin{array}{l}\text { N.Y. v. Uplinger, } \\
467 \text { U.S. } 246 \\
(1984) .\end{array}$ & $\begin{array}{l}\text { Challenge to New York statute of loitering for the purpose of } \\
\text { deviant sexual behavior, invalidated by New York courts as a } \\
\text { precursor to consensual sodomy which was no longer illegal. } \\
\text { Majority: certiorari improvidently granted. Dissent (White with } \\
\text { all) would reach merits. }\end{array}$ & Criml, liberal \\
\hline $\begin{array}{l}\text { Shea v. La., } 470 \\
\text { U.S. } 51 \text { (1985). }\end{array}$ & $\begin{array}{l}\text { Suppression of confession after request for attorney. Dissent } 1 \\
\text { (White with all), "Today, however, the majority concludes that } \\
\text { notwithstanding the substantial reasons for restricting the } \\
\text { application of Edwards to cases involving interrogations that } \\
\text { postdate the Court's opinion in Edwards, the Edwards rule must } \\
\text { be applied retroactively." “... [C]annot concur in the approach } \\
\text { to retroactivity adopted by today's majority—an approach that, } \\
\text { if our precedents regarding the nonretroactivity of decisions } \\
\text { marking a clear break with the past remain undisturbed, merely } \\
\text { adds a confusing and unjustifiable addendum to our } \\
\text { retroactivity jurisprudence." Dissent } 2 \text { (Rehnquist), adopt all of } \\
\text { Harlan's retroactivity theory. }\end{array}$ & CrimPro, liberal \\
\hline $\begin{array}{l}\text { Lindahl v. Office } \\
\text { of Pers. Mgmt., } \\
470 \text { U.S. } 768 \\
(1985) \text {. }\end{array}$ & $\begin{array}{l}\text { Dissent (White with all), "[T]he majority concludes that } \\
\text { notwithstanding the review preclusion provision of } \S 8347(\mathrm{c}) \text {, } \\
\text { petitioner is entitled to judicial review of the denial of his claim } \\
\text { for disability retirement benefits. In the view of the majority, } \\
\S 8347(\mathrm{c}) \text { must be interpreted to preclude judicial review only } \\
\text { of OPM's factual determinations, not of questions of law. } \\
\text { Because I consider the exercise in statutory construction that } \\
\text { supports this conclusion fundamentally unsound, I dissent." } \\
\text { Categorized as social because it is about disability payments. } \\
\text { Could also be about the administration of benefits, i.e., admin, } \\
\text { but that seems less central in the opinion. }\end{array}$ & Social, liberal \\
\hline $\begin{array}{l}\text { Sch. Dist. of Grand } \\
\text { Rapids v. Ball, } 473 \\
\text { U.S. } 373 \text { (1985). }\end{array}$ & $\begin{array}{l}\text { Invalidates programs teaching to nonpublic school students. } \\
\text { Dissent } 1 \text { (Burton) would uphold one of the two programs. } \\
\text { Dissent } 2 \text { (O'Connor), same. Dissent } 3 \text { (Rehnquist), "[O]ne } \\
\text { wonders how the teaching of 'Math Topics,' 'Spanish,' and } \\
\text { 'Gymnastics,' which is struck down today, creates a greater } \\
\text { 'symbolic link' than ... " Dissent } 4 \text { (White), "'not required by } \\
\text { the First Amendment and . . . contrary to the long-range } \\
\text { interests of the country.'" }\end{array}$ & $\begin{array}{l}\text { Education, } \\
\text { liberal }\end{array}$ \\
\hline
\end{tabular}




\begin{tabular}{|c|c|c|}
\hline $\begin{array}{l}\text { Aguilar v. Felton, } \\
473 \text { U.S. } 402 \\
(1985) .\end{array}$ & $\begin{array}{l}\text { Invalidates New York program sending public school teachers } \\
\text { to teach non-religious subjects in religious schools. Dissent } 1 \\
\text { (Burger), "[O]ur duty is to determine whether the statute or } \\
\text { practice at issue is a step toward establishing a state religion" } \\
\text { and "'contrary to the long-range interests of the country." } \\
\text { Dissent } 2 \text { (Rehnquist), "[T]he Court takes advantage of the } \\
\text { 'Catch-22' paradox of its own creation ... whereby aid must be } \\
\text { supervised to ensure no entanglement but the supervision itself } \\
\text { is held to cause an entanglement." Dissent } 3 \text { (O'Connor with } \\
\text { Rehnquist), "[c]ondemns benign cooperation between church } \\
\text { and state." }\end{array}$ & $\begin{array}{l}\text { E d u c a tion, } \\
\text { liberal }\end{array}$ \\
\hline $\begin{array}{l}\text { Me. v. Moulton, } \\
474 \text { U.S. } 159 \\
(1985) .\end{array}$ & $\begin{array}{l}\text { Post-indictment statements to informant, inadmissible. Dissent } \\
\text { (Burger with all), "Nothing whatever in the Constitution or our } \\
\text { prior opinions supports this bizarre result, which creates a new } \\
\text { 'right' only for those possibly habitual offenders who persist in } \\
\text { criminal activity even while under indictment for other } \\
\text { crimes." }\end{array}$ & CrimPro, liberal \\
\hline $\begin{array}{l}\text { Midlantic Nat'l } \\
\text { Bank v. N.J. Dep't } \\
\text { of Envtl. Prot., } 474 \\
\text { U.S. } 494 \text { (1986). }\end{array}$ & $\begin{array}{l}\text { Superfund abandonment by bankruptcy trustee; majority } \\
\text { requires the court to impose conditions protecting public safety } \\
\text { (e.g., cleanup). Dissent (Rehnquist with all), "a misreading of } \\
\text { three pre-Code cases, the elevation of that misreading into a } \\
\text { 'well-recognized' exception to the abandonment power, and the } \\
\text { unsupported assertion that Congress must have meant to codify } \\
\text { the exception..." }\end{array}$ & Business, libera \\
\hline $\begin{array}{l}\text { Thornburgh v. Am. } \\
\text { C o } 11 \text { o f } \\
\text { Obstetricians \& } \\
\text { Gynecologists, } 476 \\
\text { U.S. } 747 \text { (1986). }\end{array}$ & $\begin{array}{l}\text { Abortion conditions of Pennsylvania stuck down. Dissent } 1 \\
\text { (Burger), whereas Roe merely required states not to absolutely } \\
\text { bar abortions, "[t]oday the Court astonishingly goes so far as } \\
\text { to say that the State may not even require that a woman } \\
\text { contemplating an abortion be provided with accurate medical } \\
\text { information concerning the risks." Dissent } 2 \text { (White with } \\
\text { Rehnquist), substantive due process quagmire. Dissent } 3 \\
\text { (O'Connor with Rehnquist), "[N]o legal rule or doctrine is safe } \\
\text { from ad hoc nullification by this Court when an occasion for its } \\
\text { application arises in a case involving state regulation of } \\
\text { abortion." }\end{array}$ & Social, liberal \\
\hline $\begin{array}{l}\text { F o r d } \quad \text { v . } \\
\text { Wainwright, } 477 \\
\text { U.S. } 399(1986) .\end{array}$ & $\begin{array}{l}\text { Death penalty on insane inappropriate; Florida procedures } \\
\text { inadequate. Dissent } 1 \text { (O'Connor with White), no such Eighth } \\
\text { Amendment right as per Dissent 2; Florida procedures should } \\
\text { be guided. Dissent } 2 \text { (Rehnquist with Burger), no such Eighth } \\
\text { Amendment right. }\end{array}$ & Criml, liberal \\
\hline $\begin{array}{l}\text { Riverside } \quad \text { v. } \\
\text { Rivera, } 477 \text { U.S. } \\
561(1986) .\end{array}$ & $\begin{array}{l}\text { Affirming attorneys' fees in civil rights liability. Dissent } 1 \\
\text { (Burger), size of fees for novices absurd. Dissent } 2 \text { (Rehnquist } \\
\text { with all), reasonable fees cannot mean spending almost } 2,000 \\
\text { hours to recover } \$ 33,000 \text {. }\end{array}$ & Admin, liberal \\
\hline $\begin{array}{l}\text { Local } 28 \text { of The } \\
\text { She e t M e t a } 1 \\
\text { Workers' Int'l Ass'n } \\
\text { v. EEOC, } 478 \text { U.S. } \\
421 \text { (1986). }\end{array}$ & $\begin{array}{l}\text { Remedies against union favoring nonwhite membership proper. } \\
\text { Dissent } 1 \text { (O'Connor), such racial quotas are precluded. Dissent } \\
2 \text { (White) remedy is inequitable. Dissent } 3 \text { (Rehnquist with } \\
\text { Burger), remedy should only accrue in favor of victims of } \\
\text { discrimination. }\end{array}$ & Social, liberal \\
\hline
\end{tabular}




\section{BLACKMUN-BRENNAN-MARSHALL-O'CONNOR-POWELL (ELEVEN O'CLOCK)}

\begin{tabular}{|c|c|c|}
\hline $\begin{array}{l}\text { FCC v. League of } \\
\text { Women Voters of } \\
\text { Cal., } 468 \text { U.S. } 364 \\
(1984) .\end{array}$ & $\begin{array}{l}\text { Dissent } 1 \text { (Rehnquist, Burger, \& White), "Congress in enacting } \\
\S 399 \text { of the Public Broadcasting Act, } 47 \text { U.S.C. } \S 399 \text {, has } \\
\text { simply determined that public funds shall not be used to } \\
\text { subsidize noncommercial, educational broadcasting stations } \\
\text { which engage in 'editorializing' or which support or oppose } \\
\text { any political candidate. I do not believe that anything in the } \\
\text { First Amendment to the United States Constitution prevents } \\
\text { Congress from choosing to spend public moneys in that } \\
\text { manner." Dissent } 2 \text { (Stevens), "By enacting the statutory } \\
\text { provision that the Court invalidates today, a sophisticated } \\
\text { group of legislators expressed a concern about the potential } \\
\text { impact of Government funds on pervasive and powerful organs } \\
\text { of mass communication. One need not have heard the raucous } \\
\text { voice of Adolf Hitler over Radio Berlin to appreciate the } \\
\text { importance of that concern." }\end{array}$ & Speech, liberal \\
\hline $\begin{array}{l}\text { County of Oneida, } \\
\text { N.Y. v. Oneida } \\
\text { Indian Nation of } \\
\text { N.Y., } 470 \text { U.S. } 226 \\
(1985) \text {. }\end{array}$ & $\begin{array}{l}\text { Plurality upholds liability of NY counties to Indian tribes for } \\
\text { occupied land. Concurrence in part, Dissent in part (Brennan } \\
\text { with Marshall) claim state should survive, Eleventh } \\
\text { Amendment only between noncitizens and state. Dissent } \\
\text { (Stevens with all), Indians made transfer for valuable } \\
\text { consideration } 175 \text { years before, time-barred. }\end{array}$ & Tribal, liberal \\
\hline $\begin{array}{l}\text { Phila. Newspapers, } \\
\text { v. Hepps, } 475 \text { U.S. } \\
767 \text { (1986). }\end{array}$ & $\begin{array}{l}\text { One who alleges defamation from speech of public concern } \\
\text { must show its falsity. Concurrence (Brennan with Blackmun), } \\
\text { all defendants, not only media. Dissent (Stevens with all), } \\
\text { majority benefits negligent defendants/speakers; "I do not } \\
\text { agree that our precedents require a private individual to bear } \\
\text { the risk that a defamatory statement-uttered either with a } \\
\text { mind toward assassinating his good name or with careless } \\
\text { indifference to that possibility - cannot be proven false." }\end{array}$ & Speech, liberal \\
\hline
\end{tabular}

\section{BURGER-BLACKMUN-MARSHALL-POWELL-White (TWELVE O’CLOCK)}

\begin{tabular}{|c|c|c|}
\hline $\begin{array}{l}\text { Dickerson v. New } \\
\text { Banner Inst., Inc., } \\
460 \text { U.S. } 103 \\
(1983) .\end{array}$ & $\begin{array}{l}\text { Majority: Iowa expunction of conviction does not remove } \\
\text { federal ban on shipping firearms. Dissent (Rehnquist with all), } \\
\text { plea to probation is not conviction preventing right to ship } \\
\text { firearms. }\end{array}$ & $\begin{array}{l}\text { C } \mathrm{r} \text { i } \mathrm{m} \mathrm{l} \text {, } \\
\text { conservative }\end{array}$ \\
\hline $\begin{array}{l}\text { Jefferson County } \\
\text { Pharm. Ass'n, v. } \\
\text { Abbott Labs., } 460 \\
\text { U.S. } 150 \text { (1983). }\end{array}$ & $\begin{array}{l}\text { Sales of pharmaceuticals to state for resale is not exempt from } \\
\text { antitrust. Dissent } 1 \text { (Stevens) would exempt all governmental } \\
\text { purchases from antitrust. Dissent } 2 \text { (O'Connor with Brennan, } \\
\text { Rehnquist, Stevens) thinks clearly state purchases are not } \\
\text { within the act. }\end{array}$ & Business, liberal \\
\hline $\begin{array}{l}\text { Dixson v. United } \\
\text { States, } 465 \text { U.S. } \\
482 \text { (1984). }\end{array}$ & $\begin{array}{l}\text { Private administrators of public housing are within federal anti- } \\
\text { bribery statute definition of public official. Dissent (O'Connor } \\
\text { with all), violating rule of lenity. }\end{array}$ & $\begin{array}{l}\mathrm{C} \text { r i m } 1 \text {, } \\
\text { conservative }\end{array}$ \\
\hline $\begin{array}{l}\text { United States v. } \\
\text { Yermian, } 468 \text { U.S. } \\
63 \text { (1984). }\end{array}$ & $\begin{array}{l}\text { Proof of actual knowledge of federal agency jurisdiction not } \\
\text { necessary for conviction of false statement to federal agency. } \\
\text { Dissent (Rehnquist with all) would require actual knowledge. }\end{array}$ & $\begin{array}{l}\mathrm{C} \text { r i m } 1 \text {, } \\
\text { conservative }\end{array}$ \\
\hline
\end{tabular}




\section{BURGER-BLACKMUN-O'CONNOR-POWELL-REHNQUIST (ONE O'CLOCK)}

\begin{tabular}{|c|c|c|}
\hline $\begin{array}{l}\text { Rose v. Lundy, } 455 \\
\text { U.S. } 509 \text { (1982). }\end{array}$ & $\begin{array}{l}\text { Habeas only after all state remedies totally exhausted. } \\
\text { Concurrence (Blackmun), "Remitting a habeas petitioner to } \\
\text { state court to exhaust a patently frivolous claim before the } \\
\text { federal court may consider a serious, exhausted ground for } \\
\text { relief hardly demonstrates respect for the state courts." Dissent } \\
1 \text { (Brennan with Marshall), "[W]hen the prisoner later brings } \\
\text { a second petition based on the previously unexhausted claims } \\
\text { that had earlier been refused a hearing, then the remedy of } \\
\text { dismissal for 'abuse of the writ' cannot be employed against } \\
\text { that second petition, absent unusual factual circumstances truly } \\
\text { suggesting abuse." Dissent } 2 \text { (White), "[R]ule on the exhausted } \\
\text { claims ... " Dissent } 3 \text { (Stevens), "[T]he Court today fashions } \\
\text { a new rule . . . that will merely delay . . and . . impose } \\
\text { unnecessary burdens on both state and federal judges." }\end{array}$ & $\begin{array}{l}\text { C r i m P r o, } \\
\text { conservative }\end{array}$ \\
\hline $\begin{array}{l}\text { Ariz. Governing } \\
\text { Comm. for Tax } \\
\text { Deferred Annuity } \\
\& \text { Deferred Comp. } \\
\text { Plans v. Norris, } \\
463 \text { U.S. } 1073 \\
(1983) .\end{array}$ & $\begin{array}{l}\text { Employer is not allowed to offer retirement annuities that pay } \\
\text { less to (longer-living-on-average) women. Dissent (Powell } \\
\text { with all), "The Court today holds that an employer may not } \\
\text { offer its employees life annuities from a private insurance } \\
\text { company that uses actuarially sound, sex-based mortality } \\
\text { tables. This holding will have a far-reaching effect on the } \\
\text { operation of insurance and pension plans. Employers may be } \\
\text { forced to discontinue offering life annuities, or potentially } \\
\text { disruptive changes may be required in long-established } \\
\text { methods of calculating insurance and pensions." Concurrence } \\
\text { (O'Connor). }\end{array}$ & Social, liberal \\
\hline $\begin{array}{l}\text { W o o d a r d v } \\
\text { Hutchins, } 464 \text { U.S. } \\
377 \text { (1984). }\end{array}$ & $\begin{array}{l}\text { Per curiam. Last minute death habeas stay; stay vacated, abuse } \\
\text { of writ; several dissents. }\end{array}$ & $\begin{array}{l}\text { C r i m P r o, } \\
\text { conservative }\end{array}$ \\
\hline $\begin{array}{l}\text { INS v. Lopez- } \\
\text { Mendoza, } 468 \text { U.S. } \\
1032 \text { (1984). }\end{array}$ & $\begin{array}{l}\text { Exclusionary rule does not apply to deportation proceedings. } \\
\text { Dissent } 1 \text { (Brennan), exclusionary rule must apply, founded on } \\
\text { Fourth Amendment. Dissent } 2 \text { (White), exclusionary rule must } \\
\text { apply, wrong incentives. Dissent } 3 \text { (Marshall), "[A] sufficient } \\
\text { reason for excluding from civil deportation proceedings } \\
\text { evidence obtained in violation of the Fourth Amendment is that } \\
\text { there is no other way to achieve "the twin goals of enabling the } \\
\text { judiciary to avoid the taint of partnership in official lawlessness } \\
\text { and of assuring the people-all potential victims of unlawful } \\
\text { government conduct- that the government would not profit } \\
\text { from its lawless behavior." Dissent } 4 \text { (Stevens) agrees with } \\
\text { White mostly. }\end{array}$ & $\begin{array}{l}\text { A } \mathrm{d} \mathrm{m} \text { i } \mathrm{n}, \\
\text { conservative }\end{array}$ \\
\hline $\begin{array}{l}\text { N.Y. v. Class, } 475 \\
\text { U.S. } 106 \text { (1986). }\end{array}$ & $\begin{array}{l}\text { Gun found while checking car's VIN not suppressed, no } \\
\text { privacy in VIN. Dissent } 1 \text { (Brennan with Marshall, Stevens), } \\
\text { the search was not permissible. Dissent } 2 \text { (White with Stevens), } \\
\text { car interior protected from warrantless searches. }\end{array}$ & $\begin{array}{l}\mathrm{C} \mathrm{r} \mathrm{i} \mathrm{m} \mathrm{P} \mathrm{r} \mathrm{o,} \\
\text { conservative }\end{array}$ \\
\hline
\end{tabular}




\section{BuRger-PowelL-ReHNQUist-STEVENS-White (Two o'Clock)}

\begin{tabular}{|c|c|c|}
\hline $\begin{array}{l}\text { FBI v. Abramson, } \\
456 \text { U.S. } 615 \\
(1982) .\end{array}$ & $\begin{array}{l}\text { FBI may avoid journalist's FOIA request that is intrusive upon } \\
\text { privacy of investigated individual. Dissents (not in text). }\end{array}$ & $\begin{array}{l}\text { A } \mathrm{d} \mathrm{m} \mathrm{i} \mathrm{n}, \\
\text { conservative }\end{array}$ \\
\hline $\begin{array}{l}\text { United Bhd. of } \\
\text { Carpenters \& } \\
\text { Joiners of Am., } \\
\text { Local } 610 \text { v. Scott, } \\
463 \text { U.S. } 825 \\
(1983) \text {. }\end{array}$ & $\begin{array}{l}\text { Sec. } 1985 \text { (against conspiracies to deprive equal protection) } \\
\text { liability does not attach to union's attack on nonunion shop } \\
\text { despite conspiracy because First Amendment violation needs } \\
\text { state action. Dissent (Blackmun with all), "Today, in a classic } \\
\text { case of mob violence intended to intimidate persons from } \\
\text { exercising their legal rights, the Court holds that the Ku Klux } \\
\text { Klan Act provides no protection." If about labor, then liberal; } \\
\text { but seen about civil rights liability (narrowing), hence } \\
\text { conservative. }\end{array}$ & $\begin{array}{l}\text { S o c i a } 1 \\
\text { conservative }\end{array}$ \\
\hline $\begin{array}{l}\text { Herb's Welding, } \\
\text { Inc., v. Gray, } 470 \\
\text { U.S. } 414 \text { (1985). }\end{array}$ & $\begin{array}{l}\text { Longshoremen and Harborworkers Compensation Act does not } \\
\text { reach welder on fixed rig. Dissent (Marshall with all), if the rig } \\
\text { were floating welder would be covered, should be covered. }\end{array}$ & $\begin{array}{l}\text { B u s i n e s s, } \\
\text { conservative }\end{array}$ \\
\hline $\begin{array}{l}\text { Goldma n } \\
\text { Weinberger, } \quad 475 \\
\text { U.S. } 503 \text { (1986). }\end{array}$ & $\begin{array}{l}\text { 1st amendment does not enable religious hat while in uniform. } \\
\text { Concurrence (Stevens with White, Powell). Dissent } 1 \text { (Brennan } \\
\text { with Marshall), should scrutinize military regulations. Dissent } \\
2 \text { (Blackmun), government made no showing of costs. Dissent } \\
3 \text { (O'Connor with Marshall), court should articulate standard. }\end{array}$ & $\begin{array}{l}\text { A } \mathrm{d} \mathrm{m} \mathrm{i} \mathrm{n}, \\
\text { conservative }\end{array}$ \\
\hline
\end{tabular}

\section{BURGER-O'CONNOR-POWELL-REHNQUIST-WHITE (THREE O'CLOCK)}

\begin{tabular}{|c|c|c|}
\hline $\begin{array}{l}\text { Cabell v. Chavez- } \\
\text { Salido, } 454 \text { U.S. } \\
432 \text { (1982). }\end{array}$ & $\begin{array}{l}\text { California may require its peace officers to be citizens. Dissent } \\
\text { (Blackmun with all), "reinstates the deadening mantle of state } \\
\text { parochialism in public employment." }\end{array}$ & $\begin{array}{l}\mathrm{S} \text { o c i a } 1, \\
\text { conservative }\end{array}$ \\
\hline $\begin{array}{l}\text { Valley Forge } \\
\text { Christian Coll. v. } \\
\text { Ams. United For } \\
\text { Separation of } \\
\text { Church \& State, } \\
\text { Inc., } 454 \text { U.S. } 464 \\
(1982) .\end{array}$ & $\begin{array}{l}\text { Organization has no standing to enforce First Amendment } \\
\text { (establishment in educational spending). Dissent } 1 \text { (Brennan } \\
\text { with Marshall, Blackmun), "court disregards its constitutional } \\
\text { responsibility . . . Dissent } 2 \text { (Stevens), "tenuous distinction } \\
\text { between the Spending and the Property Clause." }\end{array}$ & $\begin{array}{l}\mathrm{S} \text { o c i a } 1 \\
\text { conservative }\end{array}$ \\
\hline $\begin{array}{l}\text { American Tobacco } \\
\text { Co. v. Patterson, } \\
456 \text { U.S. } 63 \text { (1982). }\end{array}$ & $\begin{array}{l}\text { EEOC loses discrimination claim against seniority plan. } \\
\text { Dissent } 1 \text { (Brennan with Marshall, Blackmun), "court turns } \\
\text { blind eye to both language and legislative history of statutory } \\
\text { provision." Dissent } 2 \text { (Stevens), "[A] seniority system that is } \\
\text { unlawful [when] adopted cannot be 'bona fide' within the } \\
\text { meaning of [the statute]. }\end{array}$ & $\begin{array}{l}\mathrm{S} \text { o c i a } 1, \\
\text { conservative }\end{array}$ \\
\hline $\begin{array}{l}\text { Kremer v. Chem. } \\
\text { Constr. Corp., } 456 \\
\text { U.S. } 461 \text { (1982). }\end{array}$ & $\begin{array}{l}\text { Title VII discrimination claim adjudicated and rejected by New } \\
\text { York courts binding upon federal who also dismiss. Dissent } 1 \\
\text { (Blackmun, Brennan, \& Marshall), "for a compelling array of } \\
\text { reasons, the court is wrong." Dissent } 2 \text { (Stevens) if review } \\
\text { under arbitrary and capricious standard then majority errs. }\end{array}$ & $\begin{array}{l}\mathrm{S} \text { o c i a } 1 \text {, } \\
\text { conservative }\end{array}$ \\
\hline
\end{tabular}




\begin{tabular}{|c|c|c|}
\hline $\begin{array}{l}\text { M a rshall } v \text {. } \\
\text { Lonberger, } 459 \\
\text { U.S. } 422(1983) .\end{array}$ & $\begin{array}{l}\text { Habeas, defendant loses. Dissent } 1 \text { (Brennan \& Marshall) } \\
\text { "inherently prejudicial to admit an unconstitutional, } \\
\text { uncounseled prior conviction." Dissent } 2 \text { (Blackmun) "enough } \\
\text { for me in this case to note the utter absence of a legitimate state } \\
\text { interest once the prosecution refused to accept respondent's } \\
\text { proffered stipulation. That refusal revealed that the prosecution } \\
\text { believed the indictment had prejudicial value." Dissent } 3 \\
\text { (Stevens, Brennan, Marshall, \& Blackmun), "The prosecutor's } \\
\text { naked desire to inject prejudice into the record had the effect of } \\
\text { complicating and prolonging the proceedings in this case and } \\
\text { deprived the respondent of his Constitutional right to a fair } \\
\text { trial." }\end{array}$ & $\begin{array}{l}\text { C r i m P r o, } \\
\text { conservative }\end{array}$ \\
\hline $\begin{array}{l}\text { Hewitt v. Helms, } \\
459 \text { U.S. } 460 \\
(1983) .\end{array}$ & $\begin{array}{l}\text { Prison administrative hearing was sufficient due process for } \\
\text { isolation; dissent (Blackmun) not sufficient due process. } \\
\text { Dissent } 2 \text { (Stevens, Brennan, \& Marshall) not clear the process } \\
\text { satisfied mandates of due process. }\end{array}$ & $\begin{array}{l}\text { C } \mathrm{r} \text { i } \mathrm{m} 1, \\
\text { conservative }\end{array}$ \\
\hline $\begin{array}{l}\text { City of Los } \\
\text { Angeles v. Lyons, } \\
\text { 461 U.S. } 95 \text { (1983). }\end{array}$ & $\begin{array}{l}\text { Chokehold pattern of LAPD did not create grounds for } \\
\text { injunction claim of this choked victim. Dissent (Marshall with } \\
\text { all), "The District Court found that the City of Los Angeles } \\
\text { authorizes its police officers to apply life-threatening } \\
\text { chokeholds to citizens who pose no threat of violence, and that } \\
\text { respondent, Adolph Lyons, was subjected to such a chokehold. } \\
\text { The Court today holds that a federal court is without power to } \\
\text { enjoin the enforcement of the City's policy, no matter how } \\
\text { flagrantly unconstitutional it may be." }\end{array}$ & $\begin{array}{l}\mathrm{S} \text { o c i a } 1, \\
\text { conservative }\end{array}$ \\
\hline $\begin{array}{l}\text { Connick v. Myers, } \\
461 \text { U.S. } 138 \\
(1983) .\end{array}$ & $\begin{array}{l}\text { Attorney's discharge did not violate her free speech rights. } \\
\text { Dissent, (Brennan with all), "Sheila Myers was discharged for } \\
\text { circulating a questionnaire to her fellow Assistant District } \\
\text { Attorneys seeking information about the effect of petitioner's } \\
\text { personnel policies on employee morale and the overall work } \\
\text { performance of the District Attorney's Office. The Court } \\
\text { concludes that her dismissal does not violate the First } \\
\text { Amendment, primarily because the questionnaire addresses } \\
\text { matters that, in the Court's view, are not of public concern. It } \\
\text { is hornbook law, however, that speech about 'the manner in } \\
\text { which government is operated or should be operated' is an } \\
\text { essential part of the communications necessary for self- } \\
\text { governance the protection of which was a central purpose of } \\
\text { the First Amendment." }\end{array}$ & $\begin{array}{l}\mathrm{S} p \text { e e c h, } \\
\text { conservative }\end{array}$ \\
\hline $\begin{array}{l}\text { H e n s } 1 \text { e y v . } \\
\text { Eckerhart, } 461 \text { U.S. } \\
424 \text { (1983). }\end{array}$ & $\begin{array}{l}\text { Attorney fees about challenge to conditions in forensic } \\
\text { hospital; fees reduced; Dissent, (Brennan with all), "the District } \\
\text { Court in this case awarded a fee that was well within the court's } \\
\text { zone of discretion under } \S 1988 \text {, and it explained the amount } \\
\text { of the fee meticulously ... Vacating a fee award such as this } \\
\text { and remanding for further explanation can serve only as an } \\
\text { invitation to losing defendants to engage in what must be one } \\
\text { of the least socially productive types of litigation..." }\end{array}$ & $\begin{array}{l}\mathrm{H} \text { e a } 1 \mathrm{t} \mathrm{h}, \\
\text { conservative }\end{array}$ \\
\hline
\end{tabular}




\begin{tabular}{|c|c|c|}
\hline $\begin{array}{l}\text { P } 1 \text { a n n e d } \\
\text { Parenthood Ass'n } \\
\text { of Kan. City, Mo., } \\
\text { Inc., v. Ashcroft, } \\
462 \text { U.S. } 476 \\
(1983) \text {. }\end{array}$ & $\begin{array}{l}\text { Plurality finds second trimester burdens on abortion } \\
\text { unconstitutional, other burdens upheld; Dissent } 1 \text { (Blackmun } \\
\text { with Brennan, Marshall \& Stevens) would strike more burdens; } \\
\text { Dissent } 2 \text { (O'Connor with Rehnquist \& White) would allow } \\
\text { hospitalization requirement. }\end{array}$ & $\begin{array}{l}\text { A b o r t i o n, } \\
\text { conservative }\end{array}$ \\
\hline $\begin{array}{l}\text { Or. v. Bradshaw, } \\
462 \text { U.S. } 1039 \\
(1983) \text {. }\end{array}$ & $\begin{array}{l}\text { Confession after asking for an atty admissible because } \\
\text { defendant initiated further conversation; Dissent (Marshall with } \\
\text { all) would suppress. }\end{array}$ & $\begin{array}{l}\text { C r i m P r o, } \\
\text { conservative }\end{array}$ \\
\hline $\begin{array}{l}\text { Jones v. United } \\
\text { States, } 463 \text { U.S. } \\
354(1983) .\end{array}$ & $\begin{array}{l}\text { Defendant innocent by reason of insanity can be confined to a } \\
\text { mental hospital longer than he would have been incarcerated; } \\
\text { Dissent } 1 \text { (Brennan with Marshall \& Blackmun) would grant } \\
\text { more rights to accused. Dissent } 2 \text { (Stevens) would require clear } \\
\text { and convincing proof of need for additional hospitalization. }\end{array}$ & $\begin{array}{l}\mathrm{C} \quad \mathrm{r} \text { i } \mathrm{m} 1, \\
\text { conservative }\end{array}$ \\
\hline $\begin{array}{l}\text { Mueller v. Allen, } \\
463 \text { U.S. } 388 \\
(1983) \text {. }\end{array}$ & $\begin{array}{l}\text { Minnesota allowance of tax deductions for schooling expenses } \\
\text { did not violate establishment clause; Dissent (Marshall with } \\
\text { all), establishment clause precedent prohibits such deductions. }\end{array}$ & $\begin{array}{l}\text { Ed uc a ti o n, } \\
\text { conservative }\end{array}$ \\
\hline $\begin{array}{l}\text { Guardians Ass'n v. } \\
\text { C i vi } 1 \text { S e r v. } \\
\text { Comm'n of N.Y., } \\
463 \text { U.S. } 582 \\
(1983) \text {. }\end{array}$ & $\begin{array}{l}\text { Plurality; New York City police policy of "last hired, first } \\
\text { fired" did not entitle disadvantaged minorities to compensation } \\
\text { absent intentional discrimination. Dissent } 1 \text { (Marshall) agrees } \\
\text { with White that compensation does not require discriminatory } \\
\text { intent; Dissent } 2 \text { (Stevens with Brennan \& Blackmun) argues } \\
\text { court abandons precedent. Could be labor, social, or } \\
\text { administrative; treated as social because dissent underlines } \\
\text { general nature of change of law (not only about municipality } \\
\text { employees). }\end{array}$ & $\begin{array}{l}\text { S o c i a } 1, \\
\text { conservative }\end{array}$ \\
\hline $\begin{array}{l}\text { Ruckelshaus } \mathrm{v} . \\
\text { Sierra Club, } 463 \\
\text { U.S. } 680 \text { (1983). }\end{array}$ & $\begin{array}{l}\text { Loss of Sierra Club against EPA precludes award of attorney's } \\
\text { fees; Dissent, (Stevens with all), text does not limit fees to } \\
\text { victors. Could be administrative, social/environmental, or } \\
\text { business. Treated as business because it was about coal-fired } \\
\text { power plants rather than nature more directly. }\end{array}$ & $\begin{array}{l}\text { B u s i n e s s, } \\
\text { conservative }\end{array}$ \\
\hline $\begin{array}{l}\text { Cal. v. Ramos, } 463 \\
\text { U.S. } 992 \text { (1983). }\end{array}$ & $\begin{array}{l}\text { Death penalty jury instruction on governor powers does not } \\
\text { require reversal of death penalty; Dissent } 1 \text { (Marshall with } \\
\text { Brennan \& Blackmun), "Even if I accepted the prevailing view } \\
\text { that the death penalty may constitutionally be imposed under } \\
\text { certain circumstances, I could not agree that a State may tip the } \\
\text { balance in favor of death by informing the jury that the } \\
\text { defendant may eventually be released if he is not executed." } \\
\text { Dissent } 2 \text { (Blackmun) understands "the issue in this case to be } \\
\text { whether a State constitutionally may instruct a jury about the } \\
\text { governor's power to commute a sentence of life without parole" } \\
\text { and finds the majority to offer no arguments about that; Dissent } \\
3 \text { (Stevens) analyzed cert and decision to be about easing the } \\
\text { death penalty rather than substance. That argument leads to } \\
\text { calling this outcome about criminal law rather than procedure. }\end{array}$ & $\begin{array}{l}\text { C } \mathrm{r} \text { i } \mathrm{m} 1 \text {, } \\
\text { conservative }\end{array}$ \\
\hline
\end{tabular}




\begin{tabular}{|c|c|c|}
\hline $\begin{array}{l}\text { Autry v. Estelle, } \\
464 \text { U.S. } 1 \text { (1983). }\end{array}$ & $\begin{array}{l}\text { First habeas petition does not automatically grant stay of } \\
\text { execution; Dissent 1, (Brennan with Marshall) no death } \\
\text { penalty. Dissent } 2 \text {, (Stevens with all), "The practice adopted by } \\
\text { the majority effectively confers upon state authorities the } \\
\text { power to dictate the period in which these federal habeas } \\
\text { petitioners may seek review in this Court by scheduling an } \\
\text { execution prior to the expiration of the period for filing a } \\
\text { certiorari petition. Shortening the period allowed for filing a } \\
\text { petition on such an ad hoc basis injects uncertainty and } \\
\text { disparity into the review procedure, adds to the burdens of } \\
\text { counsel, distorts the deliberative process within this Court, and } \\
\text { increases the risk of error." }\end{array}$ & $\begin{array}{l}\text { C r i m P r o, } \\
\text { conservative }\end{array}$ \\
\hline $\begin{array}{l}\text { Iron Arrow Honor } \\
\text { Soc'y v. Heckler, } \\
464 \text { U.S. } 67 \text { (1983). }\end{array}$ & $\begin{array}{l}\text { Per curiam. Challenge by all-male society to Secretary of } \\
\text { Education treatment of university moot because university } \\
\text { changed policy. Dissent } 1 \text { (Blackmun \& Marshall) would deny } \\
\text { certiorari. Dissent } 2 \text { (Brennan), not really moot. Dissent } 3 \\
\text { (Stevens), "the parties continue to disagree as to what the } \\
\text { obligations are that federal law imposes upon the University... } \\
\text { Nevertheless, the Court holds that this case is moot." Curious } \\
\text { strategic postures with potential interest; direct result is that the } \\
\text { lower court victory of the Secretary of Education disappears } \\
\text { and the case is, therefore, a conservative outcome about a } \\
\text { social issue. }\end{array}$ & $\begin{array}{l}\mathrm{S} \text { o c i a } 1 \\
\text { conservative }\end{array}$ \\
\hline $\begin{array}{l}\text { Sec'y of The } \\
\text { Interior v. Cal., } 464 \\
\text { U.S. } 312 \text { (1984). }\end{array}$ & $\begin{array}{l}\text { Sale by Secretary of Interior of offshore oil \& gas leases does } \\
\text { not trigger statutory obligation to respect state coastal } \\
\text { management plan; Dissent (Stevens with all) frustrated that } \\
\text { court violates Congress's statutory promise to California to } \\
\text { help it protect its coasts. Can be seen as about business or } \\
\text { social/environmental, choosing former as closer to the courts } \\
\text { approach. }\end{array}$ & $\begin{array}{l}\text { B u s i n e s s, } \\
\text { conservative }\end{array}$ \\
\hline $\begin{array}{l}\text { Pennhurst State } \\
\text { Sch. \& Hosp. v. } \\
\text { Halderman, } 465 \\
\text { U.S. } 89 \text { (1984). }\end{array}$ & $\begin{array}{l}\text { Challenge to retarded confinement to mental institution; state } \\
\text { wins on 11th amendment grounds; Dissent } 1 \text { (Brennan) thinks } \\
\text { Eleventh Amendment only bars outsiders' suits; Dissent } 2 \text {, } \\
\text { (Stevens with all), "In a completely unprecedented holding, } \\
\text { today the Court concludes that Pennsylvania's sovereign } \\
\text { immunity prevents a federal court from enjoining the conduct } \\
\text { that Pennsylvania itself has prohibited." }\end{array}$ & $\begin{array}{l}\text { Fed e ra lis m, } \\
\text { conservative }\end{array}$ \\
\hline $\begin{array}{l}\text { Lynch v. Donnelly, } \\
465 \quad \text { U.S. } 668 \\
(1984) .\end{array}$ & $\begin{array}{l}\text { Display of nativity scene by city does not violate establishment } \\
\text { clause. Dissent } 1 \text { (Brennan with all), departure from precedent. } \\
\text { Dissent } 2 \text { (Blackmun with Stevens) underscores departure from } \\
\text { precedent. }\end{array}$ & $\begin{array}{l}\text { R e } 1 \text { i g i o n, } \\
\text { conservative }\end{array}$ \\
\hline $\begin{array}{l}\text { Heckler v. } \\
467 \text { U.S. } 104 \\
(1984) .\end{array}$ & $\begin{array}{l}\text { Invalidates injunction in favor of social security disability } \\
\text { claimants against secretary of health and human services. } \\
\text { Dissent, (Marshall with all) "Far from intruding clumsily into } \\
\text { a pervasively regulated area, ... the District Court fashioned } \\
\text { a meaningful, carefully-tailored statewide remedy that } \\
\text { mandated feasible, expeditious reconsideration determinations } \\
\text { and hearings, that did not cause extra cost to the Secretary or } \\
\text { reallocation to [this state] of resources from other States, and } \\
\text { that did not harm other statutory goals." }\end{array}$ & $\begin{array}{l}\text { A } \mathrm{d} \mathrm{m} \mathrm{i} \mathrm{n}, \\
\text { conservative }\end{array}$ \\
\hline
\end{tabular}




\begin{tabular}{|c|c|c|}
\hline $\begin{array}{l}\text { Sure-Tan, Inc., v. } \\
\text { NLRB, } 467 \text { U.S. } \\
883 \text { (1984). }\end{array}$ & $\begin{array}{l}\text { Employer reporting unionizing undocumented aliens for } \\
\text { deportation committed unfair labor practice, but remedy was } \\
\text { excessive; Dissent (Brennan with all), "The Court goes on, } \\
\text { however, to concoct a new standard of review, which considers } \\
\text { whether the terms of a remedial order are 'sufficiently tailored' } \\
\text { to the unfair labor practice it is intended to redress. . . } \\
\text { Applying its newly minted standard to this case, the Court } \\
\text { finds that the remedial order challenged here involved the } \\
\text { imposition of requirements on petitioners that 'd[o] not lie } \\
\text { within the Board's own powers.' ... Our prior cases, however, } \\
\text { provide no support whatsoever for this new standard." } \\
\text { Concurrence (Powell with Rehnquist), illegal aliens are not } \\
\text { employees under NLRA. }\end{array}$ & $\begin{array}{l}\text { Employment, } \\
\text { conservative }\end{array}$ \\
\hline $\begin{array}{l}\text { Davis v. Scherer, } \\
468 \text { U.S. } 183 \\
(1984) .\end{array}$ & $\begin{array}{l}\text { Challenge by terminated police employee, defeated, notice and } \\
\text { hearing were adequate for state officers to retain immunity. } \\
\text { Dissent, (Brennan with all), the employee should win. Could } \\
\text { be considered administrative (facilitating procedures for firings } \\
\text { by states) or labor (allowing firing but decision is irrelevant to } \\
\text { private employers therefore no). }\end{array}$ & $\begin{array}{l}\text { A } \mathrm{d} \mathrm{m} \mathrm{i} \mathrm{n}, \\
\text { conservative }\end{array}$ \\
\hline $\begin{array}{l}\text { Hudson v. Palmer, } \\
468 \text { U.S. } 517 \\
(1984) .\end{array}$ & $\begin{array}{l}\text { Prisoners have no expectation of privacy in cell. Dissent, } \\
\text { (Stevens with all), "But the Court then holds that no matter } \\
\text { how malicious, destructive, or arbitrary a cell search and } \\
\text { seizure may be, it cannot constitute an unreasonable invasion } \\
\text { of any privacy or possessory interest that society is prepared to } \\
\text { recognize as reasonable." }\end{array}$ & $\begin{array}{l}\mathrm{C} \text { r i } \mathrm{m} \text { 1, } \\
\text { conservative }\end{array}$ \\
\hline $\begin{array}{l}\text { Segura v. United } \\
\text { States, } 468 \text { U.S. } \\
796(1984) .\end{array}$ & $\begin{array}{l}\text { Majority reduces scope of suppression doctrine, admitting } \\
\text { evidence pursuant to post-warrantless proper search. Dissent } \\
\text { (Stevens with all) bemoans two unaddressed constitutional law } \\
\text { violations; "The Court's disposition, I fear, will provide } \\
\text { government agents with an affirmative incentive to engage in } \\
\text { unconstitutional violations of the privacy of the home." }\end{array}$ & $\begin{array}{l}\mathrm{C} \text { r i m P r o, } \\
\text { conservative }\end{array}$ \\
\hline $\begin{array}{l}\text { United States v. } \\
\text { Young, } 470 \text { U.S. } 1 \\
\text { (1985). }\end{array}$ & $\begin{array}{l}\text { Prosecution's statement to jury that prosecution thinks the } \\
\text { defendant guilty is not error. Dissent } 1 \text {, (Brennan with Marshall } \\
\text { \& Blackmun), "remand the case to the Court of Appeals for a } \\
\text { proper plain-error inquiry." Dissent 2, (Stevens), "it is perfectly } \\
\text { clear that the Court of Appeals has already made that } \\
\text { determination. I do not understand how anyone could dispute } \\
\text { the proposition that the prosecutor's comments were obviously } \\
\text { prejudicial." }\end{array}$ & $\begin{array}{l}\text { C r i m P r o, } \\
\text { conservative }\end{array}$ \\
\hline $\begin{array}{l}\text { Dun \& Bradstreet, } \\
\text { Inc., v. Greenmoss } \\
\text { Builders, Inc., } 472 \\
\text { U.S. } 749 \text { (1985). }\end{array}$ & $\begin{array}{l}\text { Plurality: presumed and punitive damages allowed when libel } \\
\text { does not involve public figure; Dissent (Brennan with all), "We } \\
\text { believe that, although protection of the type of expression at } \\
\text { issue is admittedly not the 'central meaning of the First } \\
\text { Amendment,' } 376 \text { U.S., at } 273 \text {, Gertz makes clear that the First } \\
\text { Amendment nonetheless requires restraints on presumed and } \\
\text { punitive damages awards for this expression." }\end{array}$ & $\begin{array}{l}\mathrm{S} p \text { e e c } \mathrm{h} \\
\text { conservative }\end{array}$ \\
\hline
\end{tabular}




\begin{tabular}{|c|c|c|}
\hline $\begin{array}{l}\text { Pattern Makers' } \\
\text { League of N. Am. } \\
\text { v. NLRB, } 473 \text { U.S. } \\
95 \text { (1985). }\end{array}$ & $\begin{array}{l}\text { Plurality upholds NLRB decision against union's fining } \\
\text { members who resigned to return to work against strike. } \\
\text { Concurrence (White), NLRB exercised sensible discretion. } \\
\text { Dissent } 1 \text { (Blackmun with Brennan \& Marshall), court } \\
\text { undermined union's protected abilities to conduct strikes; } \\
\text { Dissent } 2 \text { (Stevens), statute does not protect the right to resign. }\end{array}$ & $\begin{array}{l}\text { Employment, } \\
\text { conservative }\end{array}$ \\
\hline $\begin{array}{l}\text { Atascadero State } \\
\text { Hosp. v. Scanlon, } \\
473 \text { U.S. } 234 \\
(1985) .\end{array}$ & $\begin{array}{l}\text { Majority: California had not waived sovereign immunity under } \\
\text { fed statute disbursing funds. Dissent } 1 \text { (Brennan with Marshall, } \\
\text { Blackmun, \& Stevens), court's Eleventh Amendment } \\
\text { jurisprudence "has put the federal judiciary in the unseemly } \\
\text { position of exempting the States from compliance with laws } \\
\text { that bind every other legal actor." Dissent 2, (Blackmun with } \\
\text { Brennan, Marshall, \& Stevens) "would affirm the judgment } \\
\text { here on the ground that California, as a willing recipient of } \\
\text { federal funds under the Rehabilitation Act, consented to suit } \\
\text { when it accepted such assistance." Dissent } 3 \text { (Stevens), so } \\
\text { much precedent does the court overturn that "I am now } \\
\text { persuaded that a fresh examination of the Court's Eleventh } \\
\text { Amendment jurisprudence will produce benefits that far } \\
\text { outweigh 'the consequences of further unraveling the doctrine } \\
\text { of stare decisis' in this area of the law." }\end{array}$ & $\begin{array}{l}\text { F e d e r a l is } \mathrm{m}, \\
\text { conservative }\end{array}$ \\
\hline $\begin{array}{l}\text { Cal. State Bd. of } \\
\text { Equalization v. } \\
\text { Chemehuevi Indian } \\
\text { Tribe, } 474 \text { U.S. } 9 \\
\text { (1985). }\end{array}$ & $\begin{array}{l}\text { Per Curiam: California had the right to require the tribe to } \\
\text { collect an excise tax on cigarettes sold by the tribe to non- } \\
\text { Indian purchasers reversing 9th Cir. (Reinhardt) who allowed } \\
\text { tribe not to collect tax on cigarettes sold to nonmembers. } \\
\text { Dissent } 1 \text { (Brennann) would deny certiorari. Dissent } 2 \& 3 \\
\text { (Marshall \& Blackmun) would give full hearing. Dissent } 4 \\
\text { (Stevens), "I am not prepared to say that the Court of Appeals' } \\
\text { construction of the California Code is correct or incorrect. I am } \\
\text { prepared, however, to disagree with the Court's conclusion that } \\
\text { we should undertake to decide the state-law question in a case } \\
\text { of this kind." }\end{array}$ & $\begin{array}{l}\mathrm{T} r \mathrm{i} \text { b a } 1 \\
\text { conservative }\end{array}$ \\
\hline $\begin{array}{l}\text { Pennsylvania } v . \\
\text { Goldhammer, } 474 \\
\text { U.S. } 28 \text { (1985). }\end{array}$ & $\begin{array}{l}\text { Per Curiam: No double jeopardy if conviction vacated. Dissent } \\
1 \text { (Brennan) objects to summary disposition. Dissent } 2 \\
\text { (Marshall), same underlining parties not informed. Dissent } 3 \\
\text { (Blackmun) would set for argument. Dissent } 4 \text { (Stevens), "The } \\
\text { majority recognizes that the Pennsylvania court's judgment } \\
\text { may ultimately be supported by state-law grounds. [Therefore], } \\
\text { I would simply deny certiorari." }\end{array}$ & $\begin{array}{l}\mathrm{C} \mathrm{r} \text { i m P r o, } \\
\text { conservative }\end{array}$ \\
\hline $\begin{array}{l}\text { Green v. Mansour, } \\
474 \text { U.S. } 64 \text { (1985). }\end{array}$ & $\begin{array}{l}\text { Class actions complaining of Michigan inclusion of step- } \\
\text { parents' income in AFDC calculation (statutorily ratified in the } \\
\text { meanwhile), dismissed every step as moot; Majority: Eleventh } \\
\text { Amendment, state wins. Dissent } 1 \text { (Brennan with all), "the } \\
\text { absence of a stable analytical structure underlying the Court's } \\
\text { Eleventh Amendment jurisprudence produces inconsistent } \\
\text { decisions." Dissent } 2 \text { (Marshall with Brennan \& Stevens), "In } \\
\text { abandoning the result it reached six years ago, the majority } \\
\text { misapplies its own Eleventh Amendment jurisprudence." } \\
\text { Dissent } 3 \text { (Blackmun), Michigan waived sovereign immunity } \\
\text { by accepting federal funds. }\end{array}$ & $\begin{array}{l}\text { F e d e r a } 1 \text { is } \mathrm{m}, \\
\text { conservative }\end{array}$ \\
\hline
\end{tabular}




\begin{tabular}{|c|c|c|}
\hline $\begin{array}{l}\text { United States v. } \\
\text { Loud Hawk, } 474 \\
\text { U.S. } 302(1986) \text {. }\end{array}$ & $\begin{array}{l}\text { Majority loosens speedy trial protections. Minority (Marshall } \\
\text { with all) disagree. }\end{array}$ & $\begin{array}{l}\text { C r i m P r o, } \\
\text { conservative }\end{array}$ \\
\hline $\begin{array}{l}\text { Cabana v. Bullock, } \\
474 \text { U.S. } 376 \\
(1986) \text {. }\end{array}$ & $\begin{array}{l}\text { Plurality (White), "proper course was for district court to issue } \\
\text { habeas writ vacating death sentence but to leave to state choice } \\
\text { of either imposing sentence of life imprisonment or reimposing } \\
\text { death sentence after obtaining determination from its own } \\
\text { courts of factual question whether defendant killed, attempted } \\
\text { to kill, intended to kill or intended that lethal force would be } \\
\text { used." Concurrence (Burton),"court explicitly found '[t]he } \\
\text { evidence is overwhelming that appellant was present, aiding } \\
\text { and assisting in the assault upon, and slaying of, Dickson."' } \\
\text { Dissent } 1 \text { (Brennan), death is cruel and unusual. Dissent } 2 \\
\text { (Blackmun with Brennan \& Marshall), "The Court's } \\
\text { misreading of Enmund threatens a retreat from the } \\
\text { constitutional safeguards on the capital sentencing process . } \\
\text {." Dissent } 3 \text { (Stevens with Brennan), "As the Court points out, } \\
\text { ante, at } 695-96 \text {, a Mississippi jury has not found that } \\
\text { respondent Bullock killed, attempted to kill, or intended that a } \\
\text { killing take place or that lethal force be used. It follows, in my } \\
\text { view, that a Mississippi jury has not determined that a death } \\
\text { sentence is the only response that will satisfy the outrage of the } \\
\text { community, and that a new sentencing hearing must be } \\
\text { conducted if respondent is ultimately to be sentenced to die." }\end{array}$ & $\begin{array}{l}\text { C r i m P r o, } \\
\text { conservative }\end{array}$ \\
\hline $\begin{array}{l}\text { United States v. } \\
\text { Lane, } 474 \text { U.S. } 438 \\
\text { (1986). }\end{array}$ & $\begin{array}{l}\text { Father \& son who repeatedly hired arsonist to avoid leases and } \\
\text { bad investments and recoup from insurances argue they were } \\
\text { improperly tried jointly; majority finds error harmless. Dissent } \\
1 \text { (Brennan with Blackmun), "I conclude that the question } \\
\text { whether a particular error 'affects the substantial rights of the } \\
\text { parties' does not entail a process of classification, whereby } \\
\text { some rights are deemed 'substantial' and errors affecting these } \\
\text { rights are automatically reversible. Rather, an error 'affects } \\
\text { substantial rights' only if it casts doubt on the outcome of the } \\
\text { proceeding" and would remand. Dissent } 2 \text { (Stevens with } \\
\text { Marshall), "the Court's opinion misconstrues the history and } \\
\text { purpose of Rule } 8 \text {, sows further confusion in the Court's } \\
\text { harmless-error jurisprudence, and fails to make the kind of } \\
\text { harmless-error analysis that Rule 52(a) requires. Because I do } \\
\text { not consider these errors harmless, I respectfully dissent from } \\
\text { the judgment regarding Dennis Lane in No. 84-774." }\end{array}$ & $\begin{array}{l}\text { C r i m P r o, } \\
\text { conservative }\end{array}$ \\
\hline $\begin{array}{l}\text { Whitley v. Albers, } \\
475 \text { U.S. } 312 \\
\text { (1986). }\end{array}$ & $\begin{array}{l}\text { Majority: Prisoner shot during operation against prison riot } \\
\text { cannot make } 1983 \text { claim of cruel and unusual punishment. } \\
\text { Dissent (Marshall with all), facts should get to jury. }\end{array}$ & $\begin{array}{l}\text { C } \mathrm{r} \text { i } \mathrm{m} 1, \\
\text { conservative }\end{array}$ \\
\hline
\end{tabular}




\begin{tabular}{|c|c|c|}
\hline $\begin{array}{l}\text { Wygant v. Jackson } \\
\text { Bd. of Educ., } 476 \\
\text { U.S. } 267 \text { (1986). }\end{array}$ & $\begin{array}{l}\text { Public school collective bargaining agreement giving extra } \\
\text { protections against firing to minorities violates Fourteenth } \\
\text { Amendment (concurrences by O'Connor \& by White). Dissent } \\
1 \text { (Marshall with Brennan \& Blackmun), The record and } \\
\text { extrarecord materials that we have before us persuasively } \\
\text { suggest that the plurality has too quickly assumed the absence } \\
\text { of a legitimate factual predicate, even under the plurality's own } \\
\text { view, for affirmative action in the Jackson schools." Dissent } 2 \\
\text { (Stevens), "Rather than analyzing a case of this kind by asking } \\
\text { whether minority teachers have some sort of special } \\
\text { entitlement to jobs as a remedy for sins that were committed in } \\
\text { the past, I believe that we should first ask whether the Board's } \\
\text { action advances the public interest in educating children for the } \\
\text { future. If so, I believe we should consider whether that public } \\
\text { interest, and the manner in which it is pursued, justifies any } \\
\text { adverse effects on the disadvantaged group." }\end{array}$ & $\begin{array}{l}\mathrm{S} \text { o c i a } 1, \\
\text { conservative }\end{array}$ \\
\hline $\begin{array}{l}\text { Mc Milla n } \quad \\
\text { Pennsylvaniaa, } 477 \\
\text { U.S. } 79 \text { (1986). }\end{array}$ & $\begin{array}{l}\text { Mandatory sentencing scheme of Pennsylvania upheld, where } \\
\text { possession of firearm was aggravator (shown by } \\
\text { preponderance) and not an element of the crime (beyond a } \\
\text { reasonable doubt). Dissent } 1 \text { (Marshall with Brennan \& } \\
\text { Blackmun), "I would put off until next Term any discussion of } \\
\text { how mitigating facts should be analyzed under Winship." } \\
\text { Dissent } 2 \text { (Stevens), Pennsylvania legislature saying } \\
\text { aggravating factors are not elements of the crime does not } \\
\text { allow Pennsylvania to avoid showing them with mere } \\
\text { preponderance when they are the conduct Pennsylvania } \\
\text { intended to deter. }\end{array}$ & $\begin{array}{l}\text { C } \mathrm{r} \text { i } \mathrm{m} 1 \text {, } \\
\text { conservative }\end{array}$ \\
\hline $\begin{array}{l}\mathrm{D} \text { a r d e } \mathrm{n} \quad \mathrm{v} \text {. } \\
\text { Wainwright, } 477 \\
\text { U.S. } 168(1986) .\end{array}$ & $\begin{array}{l}\text { Death habeas, challenge struck. Dissent } 1 \text { (Brennan), no death. } \\
\text { Dissent } 2 \text { (Blackmun with all), "Twice during the past year-in } \\
\text { United States v. Young, . . and again today-this Court has } \\
\text { been faced with clearly improper prosecutorial misconduct } \\
\text { during summations. Each time, the Court has condemned the } \\
\text { behavior but affirmed the conviction. . . I believe this Court } \\
\text { must do more than wring its hands when a State uses improper } \\
\text { legal standards to select juries in capital cases and permits } \\
\text { prosecutors to pervert the adversary process. I therefore } \\
\text { dissent." }\end{array}$ & $\begin{array}{l}\mathrm{C} \mathrm{r} \mathrm{i} \mathrm{m} \mathrm{P} \mathrm{r} \mathrm{o,} \\
\text { conservative }\end{array}$ \\
\hline
\end{tabular}




\begin{tabular}{|c|c|c|}
\hline $\begin{array}{l}\text { Smith v. Murray, } \\
477 \text { U.S. } 527 \\
(1986) \text {. }\end{array}$ & $\begin{array}{l}\text { Confession to psychiatrist admissible for death penalty because } \\
\text { objection was available at trial. Dissent } 1 \text { (Stevens with } \\
\text { Marshall \& Blackmun), "The Court ... is willing to assume } \\
\text { that (1) petitioner's Fifth Amendment right against compelled } \\
\text { self-incrimination was violated; (2) his Eighth Amendment } \\
\text { right to a fair, constitutionally sound sentencing proceeding } \\
\text { was violated by the introduction of the evidence from that Fifth } \\
\text { Amendment violation; and (3) those constitutional violations } \\
\text { made the difference between life and death in the jury's } \\
\text { consideration of his fate. Although the constitutional violations } \\
\text { and issues were sufficiently serious that this Court decided to } \\
\text { grant certiorari, and although the Court of Appeals for the } \\
\text { Fourth Circuit decided the issue on the merits, this Court } \\
\text { concludes that petitioner's presumably meritorious } \\
\text { constitutional claim is procedurally barred and that petitioner } \\
\text { must therefore be executed." Dissent } 2 \text { (Brennan with } \\
\text { Marshall), "Congress did not issue this Court a mandate to } \\
\text { sharpen its skills at ad hoc legislating. The same rules of } \\
\text { construction that guide interpretation of other statutes apply to } \\
\text { the federal habeas corpus statute. Accordingly, the decision } \\
\text { whether to direct federal courts to withhold habeas jurisdiction } \\
\text { clearly conferred upon them by Congress must be made with } \\
\text { the understanding that such abstention doctrines constitute } \\
\text { 'extraordinary and narrow' exceptions to the 'virtually } \\
\text { unflagging obligation' of federal courts to exercise their } \\
\text { jurisdiction." }\end{array}$ & $\begin{array}{l}\text { C r i m P r o, } \\
\text { conservative }\end{array}$ \\
\hline $\begin{array}{l}\text { B o w e r s } \quad \text { v } \\
\text { Hardwick, } 478 \\
\text { U.S. 186 (1986). }\end{array}$ & $\begin{array}{l}\text { Georgia sodomy statute is constitutional (with Burger and } \\
\text { Powell concurrences). Dissent } 1 \text { (Blackmun with all), "this . } \\
\text {. is about the ... right to be let alone." Dissent } 2 \text { (Stevens with } \\
\text { Brennan \& Marshall), "The Court orders the dismissal of } \\
\text { respondent's complaint even though the State's statute prohibits } \\
\text { all sodomy; even though that prohibition is concededly } \\
\text { unconstitutional with respect to heterosexuals; and even though } \\
\text { the State's post hoc explanations for selective application are } \\
\text { belied by the State's own actions. At the very least, I think it } \\
\text { clear at this early stage of the litigation that respondent has } \\
\text { alleged a constitutional claim sufficient to withstand a motion } \\
\text { to dismiss." }\end{array}$ & $\begin{array}{l}\mathrm{S} \text { o c i a } 1, \\
\text { conservative }\end{array}$ \\
\hline $\begin{array}{l}\text { Posadas De Puerto } \\
\text { Rico Assocs. v. } \\
\text { Tourism Co. of } \\
\text { Puerto Rico, } 478 \\
\text { U.S. } 328 \text { (1986). }\end{array}$ & $\begin{array}{l}\text { Puerto Rico statute prohibiting advertising of gambling in } \\
\text { Puerto Rico does not violate First Amendment. Dissent } 1 \\
\text { (Brennan with all), "I do not believe that Puerto Rico } \\
\text { constitutionally may suppress truthful commercial speech in } \\
\text { order to discourage its residents from engaging in lawful } \\
\text { activity." Dissent } 2 \text { (Stevens with all), "Unless the Court is } \\
\text { prepared to uphold an Illinois regulation of speech that subjects } \\
\text { the New York Times to one standard and the Chicago Tribune } \\
\text { to another, I do not understand why it is willing to uphold a } \\
\text { Puerto Rico regulation that applies one standard to the New } \\
\text { York Times and another to the San Juan Star." }\end{array}$ & $\begin{array}{l}\mathrm{S} p \text { e e c h } \\
\text { conservative }\end{array}$ \\
\hline
\end{tabular}




\begin{tabular}{|c|c|c|}
\hline $\begin{array}{l}\text { Allen v. Illinois, } \\
478 \text { U.S. } 364 \\
(1986) .\end{array}$ & $\begin{array}{l}\text { Assignment of "sexually dangerous" label was not a criminal } \\
\text { proceeding, and defendant was not entitled to full protection } \\
\text { against self-incrimination. Dissent (Stevens with all), } \\
\text { "permitting a State to create a shadow criminal law without the } \\
\text { fundamental protection of the Fifth Amendment conflicts with } \\
\text { the respect for liberty and individual dignity that has long } \\
\text { characterized, and that continues to characterize, our free } \\
\text { society." }\end{array}$ & $\begin{array}{l}\mathrm{C} \text { r i m P r o, } \\
\text { conservative }\end{array}$ \\
\hline $\begin{array}{l}\text { B a ze mor e v. } \\
\text { Friday, } 478 \text { U.S. } \\
385(1986) .\end{array}$ & $\begin{array}{l}\text { Per curiam. Orders remedies of pay disparities by race in North } \\
\text { Carolina agricultural extension services but not integration of } \\
\text { 4-H clubs, etc. Dissent (Brennan with all), "The Court of } \\
\text { Appeals determined that respondents' constitutional duty has } \\
\text { been satisfied if a plaintiff cannot point to a minority individual } \\
\text { who has been discriminated against with respect to } \\
\text { membership in a 4-H or Extension Homemaker Club. In } \\
\text { upholding the Court of Appeals in this respect, the Court joins } \\
\text { the Extension Service in winking at the Constitution's } \\
\text { requirement that States end their history of segregative } \\
\text { practices, and callously thwarts an effort to eliminate 'the last } \\
\text { vestiges of an unfortunate and ignominious page in this } \\
\text { country's history."' }\end{array}$ & $\begin{array}{l}\mathrm{S} \text { o c i a } 1, \\
\text { conservative }\end{array}$ \\
\hline $\begin{array}{l}\text { Papasan v. Allain, } \\
478 \text { U.S. } 265 \\
(1986) .\end{array}$ & $\begin{array}{l}\text { Claim on school land grant proceeds invested in destroyed trust } \\
\text { barred by Eleventh Amendment. Dissent } 1 \text { (Brennan with all), } \\
\text { Eleventh Amendment jurisprudence does not make sense. } \\
\text { Dissent } 2 \text { (Blackmun), similar. Concurrence (Powell with } \\
\text { Burger \& Rehnquist), "lands account for only } 1 \frac{1}{2} \% \text { of overall } \\
\text { funds" of schools; insignificant and would dismiss. }\end{array}$ & $\begin{array}{l}\mathrm{S} \text { o c i a } 1, \\
\text { conservative }\end{array}$ \\
\hline
\end{tabular}

\section{BURGER-O'CONNOR-POWELL-REHNQUIST-STEVENS (FOUR O'CLOCK)}

\begin{tabular}{|c|c|c|}
\hline $\begin{array}{l}\text { Tibbs v. Fla., } 457 \\
\text { U.S. } 31 \text { (1982). }\end{array}$ & $\begin{array}{l}\text { Narrowing double jeopardy. Dissent (White with all), retrial } \\
\text { without new evidence is double jeopardy. }\end{array}$ & $\begin{array}{l}\text { C r i m P r o, } \\
\text { conservative }\end{array}$ \\
\hline $\begin{array}{l}\mathrm{N} \text { i } \times \text { o } \mathrm{n} \\
\text { Fitzgerald, } 457 \\
\text { U.S. } 731 \text { (1982). }\end{array}$ & $\begin{array}{l}\text { President enjoys absolute immunity for acts within the outer } \\
\text { perimeter of his duties (Burger concurrence). Dissent } 1 \text { (White } \\
\text { with all), "If that is the case, Congress cannot provide a remedy } \\
\text { against Presidential misconduct and the criminal laws of the } \\
\text { United States are wholly inapplicable to the President. I find } \\
\text { this approach completely unacceptable." Dissent } 2 \text { (Blackmun } \\
\text { with Brennan \& Marshall), certiorari would have been denied } \\
\text { if settlement was known. }\end{array}$ & $\begin{array}{l}\text { A } \mathrm{d} \mathrm{m} \text { i } \mathrm{n} \text {, } \\
\text { conservative }\end{array}$ \\
\hline $\begin{array}{l}\text { C 1 e m e nts } \quad v . \\
\text { Fashing, } 457 \text { U.S. } \\
957 \text { (1982). }\end{array}$ & $\begin{array}{l}\text { Plurality: Texas automatic resignation and other limits on } \\
\text { officeholders seeking legislative office did not violate First } \\
\text { Amendment nor equal protection. Concurrence (Stevens), "the } \\
\text { disparate treatment in this case is not inconsistent with any } \\
\text { federal interest that is protected by the Equal Protection } \\
\text { Clause." Dissent (Brennan with Marshall, Blackmun \& } \\
\text { partially White), "no genuine justification exists that might } \\
\text { support the classifications embodied in" the Texas laws. }\end{array}$ & $\begin{array}{l}\text { A } \mathrm{d} \mathrm{m} \mathrm{i} \mathrm{n}, \\
\text { conservative }\end{array}$ \\
\hline
\end{tabular}




\begin{tabular}{|c|c|c|}
\hline $\begin{array}{l}\text { B r o w n V . } \\
\text { Thomson, } 462 \text { U.S. } \\
835 \text { (1983). }\end{array}$ & $\begin{array}{l}\text { Reapportionment challenge failed. Concurrence (O'Connor } \\
\text { with Stevens), "ensuring equal representation is not simply a } \\
\text { matter of numbers. There must be flexibility in assessing the } \\
\text { size of the deviation against the importance, consistency, and } \\
\text { neutrality of the state policies alleged to require the population } \\
\text { disparities." Dissent (Brennan with all), "[T]he overriding } \\
\text { objective must be substantial equality of population among the } \\
\text { various districts, so that the vote of any citizen is } \\
\text { approximately equal in weight of any other citizen in that } \\
\text { state." }\end{array}$ & $\begin{array}{l}\text { A } \mathrm{d} \mathrm{m} \mathrm{i} \mathrm{n}, \\
\text { conservative }\end{array}$ \\
\hline $\begin{array}{l}\text { Pub. Serv. Comm'n } \\
\text { of the State of N.Y. } \\
\text { v. Mid-Louisiana. } \\
\text { Gas Co., } 463 \text { U.S. } \\
319 \text { (1983). }\end{array}$ & $\begin{array}{l}\text { Challenge to Federal Energy Regulatory Commission } \\
\text { excluding pipeline natural gas from statutory pricing scheme; } \\
\text { majority: FERC's exclusion of pipeline production from the } \\
\text { NGPA's pricing scheme is inconsistent with the statutory } \\
\text { mandate. Dissent (White with all), "The Court today rejects the } \\
\text { agency's interpretation and substitutes its own reading of this } \\
\text { highly complex law. In doing so, the Court imposes a } \\
\text { construction not set forth in the statute itself, not addressed in } \\
\text { the legislative history, not selected by the agency, and different } \\
\text { even from that of the Court of Appeals. Notwithstanding its } \\
\text { novelty, perhaps the Court's construction that pipeline } \\
\text { production must be given 'first sale' treatment either as an } \\
\text { intracorporate transfer or at the point of a downstream sale is } \\
\text { a reasonable interpretation of the Act. But its reasonability does } \\
\text { not establish the unreasonability of the Commission's } \\
\text { interpretation, and that, of course, is the question before us." }\end{array}$ & $\begin{array}{l}\text { A } \mathrm{d} \mathrm{m} \mathrm{i} \mathrm{n}, \\
\text { conservative }\end{array}$ \\
\hline $\begin{array}{l}\text { Comm'r of Internal } \\
\text { Revenue v. Engle, } \\
464 \quad \text { U.S. } 206 \\
(1984) .\end{array}$ & $\begin{array}{l}\text { IRS pursued narrow interpretation of implied subsidy to small } \\
\text { oil producers, challenged successfully. Dissent (Blackmun with } \\
\text { all), the IRS's "administrative interpretation is entitled to } \\
\text { prevail so long as it is not 'unreasonable and plainly } \\
\text { inconsistent with the revenue statutes."' }\end{array}$ & $\begin{array}{l}\text { T a } \quad x \\
\text { conservative }\end{array}$ \\
\hline $\begin{array}{l}\text { NLRB v. Bildisco } \\
\& \quad \text { Bildisco, } 465 \\
\text { U.S. } 513(1984) .\end{array}$ & $\begin{array}{l}\text { Debtor in Possession may reject collective bargaining } \\
\text { agreement. Dissent (Brennan with all), "I cannot agree with the } \\
\text { Court's holding in Part III that a debtor in possession does not } \\
\text { commit an unfair labor practice if he unilaterally alters the } \\
\text { terms of an existing collective-bargaining agreement after a } \\
\text { bankruptcy petition has been filed, but before a Bankruptcy } \\
\text { Court has authorized the rejection of that agreement." }\end{array}$ & $\begin{array}{l}\text { B u s i n e s s, } \\
\text { conservative }\end{array}$ \\
\hline
\end{tabular}




\begin{tabular}{|c|c|c|}
\hline $\begin{array}{l}\text { Mills Music, Inc., } \\
\text { v. Snyder, } 469 \text { U.S. } \\
153 \text { (1985). }\end{array}$ & $\begin{array}{l}\text { Statutory rights to derivatives of copyrighted work; majority: } \\
\text { according to original agreement, per statutory text. Dissent } \\
\text { (White with all) would revert rights to heirs. "To allow authors } \\
\text { to recover the full amount of derivative-works royalties under } \\
\text { the Exception is not to slight the role of middlemen such as } \\
\text { music publishers in promoting public access to the arts. } \\
\text { Achieving that fundamental objective of the copyright laws } \\
\text { requires providing incentives both to the creation of works of } \\
\text { art and to their dissemination. But the need to provide } \\
\text { incentives is inapposite to the circumstances of this case, } \\
\text { because the rights at issue are attached to a term of copyright } \\
\text { that extends beyond what was contemplated by the parties at } \\
\text { the time of the initial grant. In 1940, when Ted Snyder and } \\
\text { Mills entered into their royalty-division agreement, neither } \\
\text { party could have acted in reliance on the royalties to be derived } \\
\text { from the additional } 19 \text {-year term created by the } 1976 \text { Act. In } \\
\text { this situation, the author and the grantee have each already } \\
\text { reaped the benefit of their bargain, and the only question is } \\
\text { which one should receive the windfall conferred by Congress." }\end{array}$ & $\begin{array}{l}\text { B u s i n e s s, } \\
\text { conservative }\end{array}$ \\
\hline $\begin{array}{l}\text { Henderson v. UU, } \\
476 \text { U.S. } 321 \\
(1986) .\end{array}$ & $\begin{array}{l}\text { Speedy trial rights were not violated. Dissent (White with all), } \\
\text { majority subverts the right by excluding pretrial motion } \\
\text { periods. }\end{array}$ & $\begin{array}{l}\mathrm{C} \mathrm{r} \text { i m } \mathrm{P} \mathrm{r} \mathrm{o}, \\
\text { conservative }\end{array}$ \\
\hline $\begin{array}{l}\text { Merre11 Dow } \\
\text { Pharm. Inc. v. } \\
\text { Thompson, } 478 \\
\text { U.S. } 804 \text { (1986). }\end{array}$ & $\begin{array}{l}\text { Foreign suit alleging violation of FDA act through negligence } \\
\text { presented no federal question and removal to federal court was } \\
\text { improper. Dissent (Brennan with all), "I believe that the } \\
\text { limitation on federal jurisdiction recognized by the Court today } \\
\text { is inconsistent with the purposes of } \S 1331 . "\end{array}$ & $\begin{array}{l}\text { B u s i n e s s, } \\
\text { conservative }\end{array}$ \\
\hline
\end{tabular}

\section{BURGER-BLACKMUN-O'CONNOR-REHNQUIST-WHITE (FIVE O'CLOCK)}

\begin{tabular}{|l|l|l|}
\hline $\begin{array}{l}\text { Perry Educ. Ass'n } \\
\text { v. Perry Local } \\
\text { Educators' Ass'n, } \\
\text { 460 U.S. 37 (1983). }\end{array}$ & $\begin{array}{l}\text { Union may bargain to have exclusive access to teacher } \\
\text { mailboxes, excluding rival union. Dissent (Brennan with all), } \\
\text { "the exclusive access provision in the collective bargaining } \\
\text { agreement amounts to viewpoint discrimination that infringes } \\
\text { the respondents' First Amendment rights and fails to advance } \\
\text { any substantial state interest." }\end{array}$ & $\begin{array}{l}\text { Employment, } \\
\text { conservative }\end{array}$ \\
\hline $\begin{array}{l}\text { United States v. } \\
\text { Nat'l Bank of } \\
\text { Commerce, 472 }\end{array}$ & $\begin{array}{l}\text { IRS can levy against joint accounts. Dissent (Powell with all), } \\
\text { should protect nondelinquent taxpayers joint owners. }\end{array}$ & Tax, liberal \\
U.S. 713 (1985). & & \\
\hline $\begin{array}{l}\text { Offshore Logistics, } \\
\text { Inc., v. Tallentire, } \\
477 \quad \text { U.S. 207 } \\
\text { (1986). }\end{array}$ & $\begin{array}{l}\text { Deaths in crashes from offshore drilling platforms subject to } \\
\text { deaths in high seas act, not Louisiana wrongful death. Dissent }\end{array}$ & $\begin{array}{l}\text { B u s i n e s s, } \\
\text { conservative }\end{array}$ \\
\hline
\end{tabular}




\section{BURGER-O'CONNOR-REHNQUIST-STEVENS-WHITE (SIX O'CLOCK)}

\begin{tabular}{|c|c|c|}
\hline $\begin{array}{l}\text { Regan v. Wald, } \\
468 \text { U.S. } 222 \\
(1984) .\end{array}$ & $\begin{array}{l}\text { Embargo of trading with Cuba and of travel to Cuba did not } \\
\text { violate due process. Dissent } 1 \text { (Blackmun with all), "Because } \\
\text { I do not agree that the grandfather clause encompasses the } \\
\text { exercise of Presidential power at issue here, I would affirm the } \\
\text { judgment of the United States Court of Appeals for the First } \\
\text { Circuit." Dissent } 2 \text { (Powell), "the legislative history . . } \\
\text { unmistakably demonstrates that Congress intended to bar the } \\
\text { President from expanding the exercise of emergency authority } \\
\text { under } § 5 \text { (b). Contrary to the Court's view, the meaning of the } \\
\text { word 'authorities' in the grandfather clause is not 'clear,' nor in } \\
\text { my view is it contrary to the fair import of this history." }\end{array}$ & $\begin{array}{l}\mathrm{S} \text { o c i a } 1, \\
\text { conservative }\end{array}$ \\
\hline $\begin{array}{l}\text { Sedima v. Imrex } \\
\text { Co., Inc., } 473 \text { U.S. } \\
479(1985) \text {. }\end{array}$ & $\begin{array}{l}\text { Private RICO claim enabled. Dissent } 1 \text { (Powell), "I write } \\
\text { separately to emphasize my disagreement with the Court's } \\
\text { conclusion that the statute must be applied to authorize the } \\
\text { types of private civil actions now being brought frequently } \\
\text { against respected businesses to redress ordinary fraud." Dissent } \\
2 \text { (Marshall with all), "The Court today permits two civil } \\
\text { actions for treble damages to go forward that are not authorized } \\
\text { either by the language and legislative history of the civil RICO } \\
\text { statute, or by the policies that underlay passage of that statute. } \\
\text { In so doing, the Court shirks its well-recognized responsibility } \\
\text { to assure that Congress' intent is not thwarted by maintenance } \\
\text { of unintended litigation, and it does so based on an unfounded } \\
\text { and ill-considered reading of a statutory provision." }\end{array}$ & Business, liberal \\
\hline $\begin{array}{l}\text { Am. Nat'l Bank \& } \\
\text { Trust Co. of Chi. v. } \\
\text { Haroco, Inc., } 473 \\
\text { U.S. } 606 \text { (1985). }\end{array}$ & Per curiam. Same as Sedima, 473 U.S. 479. & Business, liberal \\
\hline $\begin{array}{l}\text { California v. } \\
\text { Ciraolo, } 476 \text { U.S. } \\
207 \text { (1986). }\end{array}$ & $\begin{array}{l}\text { Warrantless aerial observation not suppressed. Dissent (Powell } \\
\text { with all), "Justice Harlan warned that any decision to construe } \\
\text { the Fourth Amendment as proscribing only physical intrusions } \\
\text { by police onto private property 'is, in the present day, bad } \\
\text { physics as well as bad law, for reasonable expectations of } \\
\text { privacy may be defeated by electronic as well as physical } \\
\text { invasion"... Because the Court today ignores that warning in an } \\
\text { opinion that departs significantly from the standard developed } \\
\text { in Katz for deciding when a Fourth Amendment violation has } \\
\text { occurred, I dissent." }\end{array}$ & $\begin{array}{l}\mathrm{C} \text { r i m P r o, } \\
\text { conservative }\end{array}$ \\
\hline $\begin{array}{l}\text { Dow Chem. Co. v. } \\
\text { United States, } 476 \\
\text { U.S. } 227 \text { (1986). }\end{array}$ & $\begin{array}{l}\text { EPA may use aerial photography without warrant. Dissent } \\
\text { (Powell with all) would hold the same as Ciraolo, } 476 \text { U.S. } \\
207 .\end{array}$ & $\begin{array}{l}\text { A } \mathrm{d} \mathrm{m} \text { i } \mathrm{n} \text {, } \\
\text { conservative }\end{array}$ \\
\hline
\end{tabular}




\section{BLACKMUN-BRENNAN-MARSHALL-O'CONNOR-STEVENS (SEVEN O'ClOCK)}

\begin{tabular}{|c|c|c|}
\hline $\begin{array}{l}\text { Karcher v. Daggett, } \\
462 \text { U.S. } 725 \\
(1983) .\end{array}$ & $\begin{array}{l}\text { Plurality remands Democratic Party-led redistricting of New } \\
\text { Jersey, (Stevens nearly arguing gerrymandering). Dissent } \\
\text { (White with all), "[T]he Court affirms the District Court's } \\
\text { decision thereby striking for the first time in the Court's } \\
\text { experience a legislative or congressional districting plan with } \\
\text { an average and maximum population variance of under } 1 \% . " \\
\text { Slant treated as conservative because it goes against districts of } \\
\text { peculiar shape and against Democratic redistricting. }\end{array}$ & $\begin{array}{l}\mathrm{V} \text { o t i n } \mathrm{g}, \\
\text { conservative }\end{array}$ \\
\hline $\begin{array}{l}\text { B e n d e r v. } \\
\text { Williamsport Area } \\
\text { Sch. Dist., } 475 \text { U.S. } \\
534 \text { (1986). }\end{array}$ & $\begin{array}{l}\text { Plurality dismisses appeal from District Ct decision allowing } \\
\text { student-led prayer. Dissent } 1 \text { (Burger with Rehnquist \& White) } \\
\text { would reach merits and uphold student-led prayer. Dissent } 2 \\
\text { (Powell) would also reach merits and find that open forum } \\
\text { allowed prayer. Since all would allow prayer, issue is reaching } \\
\text { merits which plurality declines by not giving appeal right to } \\
\text { parent. }\end{array}$ & Religion, liberal \\
\hline $\begin{array}{l}\text { Int'l Union, United } \\
\text { Auto., Aerospace, } \\
\& \quad \text { A g r i c } \\
\text { I m p } 1 \text { e m e n t } \\
\text { Workers of Am. v. } \\
\text { Brock, } 477 \text { U.S. } \\
274(1986) \text {. }\end{array}$ & $\begin{array}{l}\text { Union has standing and need not join state agencies about } \\
\text { benefits. Dissent } 1 \text { (White with Burger \& Rehnquist) would } \\
\text { find that the district court did not have jurisdiction. Dissent } 2 \\
\text { (Powell) would find that perhaps the members with claims are } \\
\text { few and union has weak incentive to pursue claims. }\end{array}$ & $\begin{array}{l}\text { Employment, } \\
\text { liberal }\end{array}$ \\
\hline $\begin{array}{l}\text { M a c D o n a } 1 \mathrm{~d}, \\
\text { Sommer \& Frates } \\
\text { v. Yolo County, } \\
477 \quad \text { U.S. } \quad 340 \\
(1986) \text {. }\end{array}$ & $\begin{array}{l}\text { Regulatory taking by refusal to approve subdivision, cannot } \\
\text { compute damages. Dissent } 1 \text { (White with all) would find that } \\
\text { a takings claim is stated and court should resolve damages. } \\
\text { Dissent } 2 \text { (Rehnquist with Powell) would remand with taking } \\
\text { instruction. }\end{array}$ & Takings, liberal \\
\hline
\end{tabular}

\section{BRENNAN-MARShALL-PowelL-STEVENS-White (EIGHT O'ClOCK)}

\begin{tabular}{|l|l|l|}
\hline $\begin{array}{l}\text { Florida v. Royer, } \\
\begin{array}{l}(1983) . \\
\text { U.S. 491 }\end{array}\end{array}$ & $\begin{array}{l}\text { Dissent 1 (Blackmun) would not ask for probable cause due to } \\
\text { difficulty of combating drug offenses. Dissent 2 (Rehnquist } \\
\text { with Burger \& O'Connor) would find the police reasonable. }\end{array}$ & CrimPro, liberal \\
\hline $\begin{array}{l}\text { M ich ig a n v. } \\
\text { Clifford, 464 U.S. } \\
287 \text { (1984). }\end{array}$ & $\begin{array}{l}\text { Homeowners' warrantless evidence of arson suppressed. } \\
\text { Concurrence (Stevens) agrees later fire marshal's entry was } \\
\text { warrantless search. Dissent (Rehnquist with Burger, Blackmun } \\
\text { \& O'Connor) finds same day return within precedent not } \\
\text { requiring warrant. }\end{array}$ & CrimPro, liberal \\
\hline
\end{tabular}




\begin{tabular}{|l|l|l|}
\hline Reed v. Ross, 468 & $\begin{array}{l}\text { At 1969, before constitutional doctrine that state had burden on } \\
\text { U.S. 1 (1984). }\end{array}$ & $\begin{array}{l}\text { CrimPro, liberal } \\
\text { malice and self-defense, justifying retrial on habeas. } \\
\text { Concurrence (Powell) would only apply new interpretations on } \\
\text { direct review but state has not objected. Dissent (Rehnquist } \\
\text { with all), "we have the anomalous situation of a jury verdict in } \\
\text { a case tried properly by then-prevailing constitutional standards } \\
\text { being set aside because of legal developments that occurred } \\
\text { long after the North Carolina conviction became final." }\end{array}$ \\
\hline
\end{tabular}

\section{Appendix B6: Tables of Kennedy Composition Majorities Producing More than Two 5-4 Opinions}

We list the opinions of the United States Supreme Court while its composition is defined by its junior justice being Kennedy. The Kennedy composition consists of two appointees of Democratic presidents (Marshall and White) and seven appointees of Republican presidents (Blackmun, Brennan, Kennedy, O'Connor, Rehnquist, Scalia, and Stevens). We list the majorities as they appear in the corresponding figure in the full-text proceeding clockwise from the nine o'clock position. The name of the case, along with the citation to the United States Reporter, and the year appears in the first column. The second column holds our brief description of the outcome compared to the dissent's position. The third column holds the legal field and the political slant of the majority's position as it arises by juxtaposition to that of the minority. We sort the justices in the majorities by, first, the chief justice, then the associate justices by alphabetical order.

\section{BLACKMUN-BRENNAN-MARSHALL-STEVENS-White (NINE O'ClOCK)}

\begin{tabular}{|l|l|l|}
\hline $\begin{array}{l}\text { Mills v. Maryland, } \\
486 \text { U.S. } 367 \\
(1988) .\end{array}$ & $\begin{array}{l}\text { Remands death for resentencing because statute made jurors } \\
\text { unclear about latitude for mitigation. Dissent (Rehnquist with } \\
\text { O'Connor, Scalia \& Kennedy) would affirm. }\end{array}$ & CrimPro, liberal \\
\hline $\begin{array}{l}\text { Houston v. Lack, } \\
487 \text { U.S. 266 } \\
(1988) .\end{array}$ & $\begin{array}{l}\text { Pro se prisoner's appeal timely as of delivery to warden rather } \\
\text { than court clerk. Dissent (Scalia with Rehnquist, O'Connor \& } \\
\text { Kennedy) finds majority takes liberty with statutory language. }\end{array}$ & CrimPro, liberal \\
\hline $\begin{array}{l}\text { South Carolina v. } \\
\text { Gathers, 490 U.S. } \\
805 \text { (1989). }\end{array}$ & $\begin{array}{l}\text { Death sentence appeal; majority finds presentation of evidence } \\
\text { about victim at sentencing improper. Dissents (O'Connor with } \\
\text { Rehnquist \& Kennedy; Scalia) would not preclude any } \\
\text { discussion of victim in sentencing. }\end{array}$ & CrimPro, liberal \\
\hline $\begin{array}{l}\text { Pennsylvania v. } \\
\text { Union Gas Co., } \\
\text { 491 U.S. 1 (1989). }\end{array}$ & $\begin{array}{l}\text { Environmental cleanup defendant can bring state as third-party } \\
\text { to impose on state some cleanup costs; three concurrences in } \\
\text { part disagree with Eleventh Amendment reasoning. }\end{array}$ & Envir'l, liberal \\
\hline $\begin{array}{l}\text { James v. Illinois, } \\
493 \text { U.S. 307 }\end{array}$ & $\begin{array}{l}\text { Murder conviction invalid because improperly obtained } \\
\text { statements of defendant were used to impeach defense witness. }\end{array}$ & CrimPro, liberal \\
(1990). & $\begin{array}{l}\text { Dissent (Kennedy with Rehnquist, O'Connor \& Scalia) would } \\
\text { permit use for impeachment. }\end{array}$ & \\
\hline
\end{tabular}




\begin{tabular}{|c|c|c|}
\hline $\begin{array}{l}\text { Zinermon v. Burch, } \\
494 \text { U.S. } 113 \\
(1990) .\end{array}$ & $\begin{array}{l}\text { Mental patient's incompetence to allow voluntary admission to } \\
\text { mental hospital grounds for liability for civil rights violation by } \\
\text { doctors. Dissent (O'Connor with Rehnquist, Scalia \& } \\
\text { Kennedy), "[w]ithout doubt, respondent Burch alleges a serious } \\
\text { deprivation of liberty; yet equally clearly he alleges no } \\
\text { violation of the Fourteenth Amendment." }\end{array}$ & Social, liberal \\
\hline $\begin{array}{l}\text { Mo. v. Jenkins, } 495 \\
\text { U.S. } 33 \text { (1990). }\end{array}$ & $\begin{array}{l}\text { Partial concurrence (Kennedy with Rehnquist, O'Connor \& } \\
\text { Scalia) would find that that the majority's dicta approving some } \\
\text { of the District Court's powers to override statutory taxation } \\
\text { limits in order to promote integration of schools were } \\
\text { unconstitutional for being too expansive of federal judicial } \\
\text { powers. }\end{array}$ & Social, liberal \\
\hline $\begin{array}{l}\text { Grady v. Corbin, } \\
495 \text { U.S. } 508 \\
(1990) \text {. }\end{array}$ & $\begin{array}{l}\text { Majority attaches double jeopardy in favor of defendant who } \\
\text { pled guilty to DUI after fatal accident and who was being } \\
\text { prosecuted for other crimes from same accident. Dissent } \\
\text { (Scalia with Rehnquist \& Kennedy) would consider offense } \\
\text { being prosecuted different. }\end{array}$ & CrimPro, liberal \\
\hline $\begin{array}{l}\text { Wilder v. Va. } \\
\text { Hosp. Ass'n, } 496 \\
\text { U.S. } 498(1990)\end{array}$ & $\begin{array}{l}\text { Dissent (Rehnquist with O'Connor, Scalia \& Kennedy) would } \\
\text { reverse the Court of Appeals' decision, which concluded that } \\
\text { health care providers could sue state officials under } \S 1983 \text { for } \\
\text { inadequate Medicaid reimbursements. }\end{array}$ & Social, liberal \\
\hline $\begin{array}{l}\text { R u t a n v . } \\
\text { Republican Party, } \\
\text { 497 U.S. 62 (1990). }\end{array}$ & $\begin{array}{l}\text { Majority finds employment decisions even beyond firing } \\
\text { violate first amendment if they regard lower level public } \\
\text { employees. Dissent (Scalia with Rehnquist, Kennedy \& } \\
\text { O'Connor) would allow government employers more latitude. }\end{array}$ & $\begin{array}{l}\text { Labor/Social, } \\
\text { liberal }\end{array}$ \\
\hline $\begin{array}{l}\text { Alvarado v. United } \\
\text { States, } 497 \text { U.S. } \\
543 \text { (1990). }\end{array}$ & $\begin{array}{l}\text { Government's use of race in excluding jurors requires reversal. } \\
\text { Dissent (Rehnquist with all) would give government more } \\
\text { leeway. }\end{array}$ & CrimPro, liberal \\
\hline $\begin{array}{l}\text { Metro Broad. v. } \\
\text { F.C.C., } 497 \text { U.S. } \\
547(1990) .\end{array}$ & $\begin{array}{l}\text { FCC's minority ownership policies did not violate equal } \\
\text { protection principles. Dissents (O'Connor with all; Kennedy } \\
\text { with Scalia) find majority's "renew[s] toleration of racial } \\
\text { classifications and...repudiat[es] of our recent affirmation that } \\
\text { the Constitution's equal protection guarantees extend equally } \\
\text { to all citizens." }\end{array}$ & Social, liberal \\
\hline
\end{tabular}

\section{BLACKMUN-BRENNAN-KeNNEDY-MaRSHALL-STEVENS (TEN O'ClOCK)}

\begin{tabular}{|l|l|l|}
\hline $\begin{array}{l}\text { Liljeberg v. Health } \\
\text { Servs. Acquisition } \\
\text { Corp., 486 U.S. } \\
847 \text { (1988). }\end{array}$ & $\begin{array}{l}\text { Majority disqualifies judge with conflict. Dissent 1 (Rehnquist } \\
\text { with White \& Scalia). Dissent 2 (O'Connor). }\end{array}$ & $\begin{array}{l}\text { Jud'l Admin'n, } \\
\text { liberal }\end{array}$ \\
\hline $\begin{array}{l}\text { Terrell v. Morris, } \\
493 \text { U.S. 1 (1989). }\end{array}$ & $\begin{array}{l}\text { Ineffective assistance; majority remands to reach substance. } \\
\text { Dissent (Rehnquist with all) would uphold dismissal of } \\
\text { challenge. }\end{array}$ & CrimPro, liberal \\
\hline $\begin{array}{l}\text { Reves. v. Ernst \& } \\
\text { Young, 494 U.S. } \\
56 \text { (1990). }\end{array}$ & $\begin{array}{l}\text { Dissent (Rehnquist with White, O'Connor \& Scalia) would } \\
\text { consider that the notes founding securities fraud claim were } \\
\text { exempt from the Act due to their short term. }\end{array}$ & $\begin{array}{l}\text { S e c r i ti e s, } \\
\text { liberal }\end{array}$ \\
\hline
\end{tabular}




\begin{tabular}{|l|l|l|}
\hline Peel v. Atty. & Commercial speech; majority finds First Amendment requires & Speech, liberal \\
Registration \& & lawyer be allowed to mention certification. Dissents (White; & \\
D i s c i p l i n a ry & O'Connor with rest) would uphold state Prof. Resp. rule & \\
Comm'n, 496 U.S. & prohibiting mention. & \\
$91(1990)$. & & \\
\hline
\end{tabular}

\section{BLACKMUN-BRENNAN-KENNEDY-MARSHALL-SCALIA (ELEVEN O'ClOCK)}

\begin{tabular}{|c|c|c|}
\hline $\begin{array}{l}\text { Pittston Coal Grp. } \\
\text { v. Sebben, } 488 \\
\text { U.S. } 105 \text { (1988). }\end{array}$ & $\begin{array}{l}\text { Labor regulations applicable to claims seeking black lung } \\
\text { benefits were impermissibly restrictive. Dissent (Stevens with } \\
\text { Rehnquist, White \& O'Connor) would uphold regulations. }\end{array}$ & Labor, liberal \\
\hline $\begin{array}{l}\text { Texas v. Johnson, } \\
491 \text { U.S. } 397 \\
(1989) .\end{array}$ & $\begin{array}{l}\text { Flag burning; First Amendment trumps Texas statute on flag } \\
\text { desecration. Dissents (Rehnquist with White and O'Connor; } \\
\text { Stevens) would uphold statute. }\end{array}$ & Speech, liberal \\
\hline $\begin{array}{l}\text { United States v. } \\
\text { Eichman, } 496 \text { U.S. } \\
310(1990) .\end{array}$ & $\begin{array}{l}\text { Flag burning; First Amendment trumps Flag Protection Act of } \\
\text { 1989. Dissent (Stevens with Rehnquist, White \& O'Connor;), } \\
\text { "remain[s] persuaded that the considerations identified } \\
\text { in...Texas v. Johnson are of controlling importance..." }\end{array}$ & Speech, liberal \\
\hline
\end{tabular}

\section{REHNQUIST-KENNEDY-O'CONNOR-SCALIA-STEVENS (TWO O'CLOCK)}

\begin{tabular}{|l|l|l|}
\hline $\begin{array}{l}\text { Michael H. v. } \\
\text { Gerald D., 491 } \\
\text { U.S. 110 (1989). }\end{array}$ & $\begin{array}{l}\text { State law's presumption that spouse is father does not violate } \\
\text { true father's due process. Dissents (Brennan with Blackmun \& } \\
\text { Marshall; White with Brennan) disagree. }\end{array}$ & $\begin{array}{l}\text { S o c i a 1 } \\
\text { conservative }\end{array}$ \\
\hline $\begin{array}{l}\text { Kaiser Aluminum } \\
\text { \& Chem. Corp. v. } \\
\text { Bonjorno, 494 U.S. } \\
827 \text { (1990). }\end{array}$ & $\begin{array}{l}\text { Post-judgement interest should be calculated according to } \\
\text { state in effect on date of judgement. Dissent (White with } \\
\text { Brennan, Marshall \& Blackmun) sees pendency of litigation } \\
\text { and would apply new statutory rate. }\end{array}$ & $\begin{array}{l}\text { T } \text { r t } \\
\text { conservative }\end{array}$ \\
\hline $\begin{array}{l}\text { Kansas v. Utilicorp } \\
\text { United, Inc., 497 }\end{array}$ & $\begin{array}{l}\text { Dissent (White with Brennan, Marshall \& Blackmun) would } \\
\text { grant Antitrust standing to customers, not only regulated } \\
\text { Utility, against overcharging by suppliers, because costs were } \\
\text { passed to customers. }\end{array}$ & $\begin{array}{l}\text { A n t i t r u s t } \\
\text { conservative }\end{array}$ \\
\hline
\end{tabular}

\section{REHNQUIST-KENNEDY-O'CONNOR-SCALIA-WHITE (THREE O'ClOCK)}

\begin{tabular}{|c|c|c|}
\hline $\begin{array}{l}\text { Patterson } v \text {. } \\
\text { McLean Credit } \\
\text { Union, } 485 \text { U.S. } \\
617 \text { (1988). }\end{array}$ & $\begin{array}{l}\text { Majority grants certiorari to reconsider Runyon v. McCrary, } \\
\text { interpreting federal civil rights statute to prohibit racial } \\
\text { discrimination in the making and enforcement of private } \\
\text { contracts. Dissent } 1 \text { (Blackmun with all) would find a violation } \\
\text { of stare decisis. Dissent } 2 \text { (Stevens with all), undermining anti- } \\
\text { discrimination is undesirable. }\end{array}$ & $\begin{array}{l}\mathrm{S} \text { o c i a } 1, \\
\text { conservative }\end{array}$ \\
\hline $\begin{array}{l}\text { Wheat v. United } \\
\text { States, } 486 \text { U.S. } \\
153 \text { (1988). }\end{array}$ & $\begin{array}{l}\text { Dissents (Marshall with Brennan; Stevens with Blackmun) } \\
\text { would consider refusal to appoint substitute counsel reversible } \\
\text { error. }\end{array}$ & $\begin{array}{l}\text { C r i m P r o, } \\
\text { conservative }\end{array}$ \\
\hline $\begin{array}{l}\text { Ross v. Oklahoma, } \\
487 \text { U.S. } 81 \text { (1988). }\end{array}$ & $\begin{array}{l}\text { Loss of peremptory challenge on juror whom the court should } \\
\text { have excused for cause is not reversible error. Dissent } \\
\text { (Marshall with Brennan, Blackmun \& Stevens) would reverse. }\end{array}$ & $\begin{array}{l}\text { C r i m P r o, } \\
\text { conservative }\end{array}$ \\
\hline
\end{tabular}




\begin{tabular}{|c|c|c|}
\hline $\begin{array}{l}\text { Florida v. } \text { Long, } \\
487 \text { U.S. } 223 \\
(1988) \text {. }\end{array}$ & $\begin{array}{l}\text { Precedent finding sex discrimination in state pension plans did } \\
\text { not apply to elective benefits and was not retroactive. Dissent } \\
1 \text { (Blackmun with Brennan \& Marshall) would impose } \\
\text { retroactive liability. Dissent } 2 \text { (Stevens), prospective relief by } \\
\text { increasing benefits should be appropriate. }\end{array}$ & $\begin{array}{l}\mathrm{S} \text { o c i a } 1, \\
\text { conservative }\end{array}$ \\
\hline $\begin{array}{l}\text { Patterson } \mathrm{v} . \\
\text { Illinois, } 487 \text { U.S. } \\
285 \text { (1988). }\end{array}$ & $\begin{array}{l}\text { Post-indictment waiver of counsel proper and subsequent } \\
\text { statements admissible. Dissent } 1 \text { (Blackmun), indictment } \\
\text { precludes waiver. Dissent } 2 \text { (Stevens with Brennan \& } \\
\text { Marshall), waiver impermissible. }\end{array}$ & $\begin{array}{l}\text { C r i m P r o, } \\
\text { conservative }\end{array}$ \\
\hline $\begin{array}{l}\text { K a d r m a s } \mathrm{v} . \\
\text { Dickinson Pub. } \\
\text { Sch., } 487 \text { U.S. } 450 \\
\text { (1988). }\end{array}$ & $\begin{array}{l}\text { Fee for school bus proper. Dissents (Marshall with Brennan; } \\
\text { Stevens with Blackmun), fees violate equal protection by } \\
\text { burdening poor families more. }\end{array}$ & $\begin{array}{l}\mathrm{S} \text { o c i a } 1, \\
\text { conservative }\end{array}$ \\
\hline $\begin{array}{l}\text { Boyle v. United } \\
\text { Techs. Corp., } 487 \\
\text { U.S. } 500 \text { (1988). }\end{array}$ & $\begin{array}{l}\text { Claimant from accident in military helicopter, majority } \\
\text { remands to establish that manufacturer followed specifications } \\
\text { and issued warning to obtain immunity under federal statute. } \\
\text { Dissents (Brennan with Marshall \& Blackmun; Stevens) would } \\
\text { allow liability under state law. }\end{array}$ & $\begin{array}{l}\mathrm{T} \text { o } \mathrm{r} \quad \mathrm{t}, \\
\text { conservative }\end{array}$ \\
\hline $\begin{array}{l}\text { B o w e } n \quad v \text {. } \\
\text { Kendrick, } 487 \text { U.S. } \\
589 \text { (1988). }\end{array}$ & $\begin{array}{l}\text { Act making grants for services about premarital adolescent } \\
\text { sexual relations does not establish religion. Dissent (Blackmun } \\
\text { with Brennan, Marshall \& Stevens) disagrees. }\end{array}$ & $\begin{array}{l}\text { Establishment, } \\
\text { conservative }\end{array}$ \\
\hline $\begin{array}{l}\text { Florida v. Riley, } \\
488 \text { U.S. } 445 \\
(1989)\end{array}$ & $\begin{array}{l}\text { Observation of marijuana in greenhouse from helicopter } \\
\text { overflight at } 400 \mathrm{ft} \text { proper grounds for search warrant. Dissents } \\
\text { (Brennan with Marshall \& Stevens; Blackmun) would require } \\
\text { warrant for overflight. }\end{array}$ & $\begin{array}{l}\mathrm{C} \text { r i m P r o, } \\
\text { conservative }\end{array}$ \\
\hline $\begin{array}{l}\text { In re McDonald, } \\
489 \text { U.S. } 180 \\
(1989) \text {. }\end{array}$ & $\begin{array}{l}\text { Convict with history of frivolous petitions could be denied } \\
\text { leave pro forma pauperis. Dissent (Brennan with Marshall, } \\
\text { Blackmun \& Stevens) would deny habeas without reaching } \\
\text { issue. }\end{array}$ & $\begin{array}{l}\text { C r i m P r o, } \\
\text { conservative }\end{array}$ \\
\hline $\begin{array}{l}\text { Dugger v. Adams, } \\
489 \text { U.S. } 401 \\
(1989) \text {. }\end{array}$ & $\begin{array}{l}\text { Death habeas; not having raised impropriety of jury instruction } \\
\text { on appeal or objected to it precludes raising it on habeas. } \\
\text { Dissent (Blackmun with Brennan, Marshall \& Stevens), "this } \\
\text { Court is sending a man to a presumptively unlawful execution } \\
\text { because he or his lawyers did not raise his objection at what is } \\
\text { felt to be the appropriate time for doing so." }\end{array}$ & $\begin{array}{l}\text { C r i m P r o, } \\
\text { conservative }\end{array}$ \\
\hline $\begin{array}{l}\text { Rodriguez de } \\
\text { Q u i j a s v. } \\
\text { Shearson/Am. Exp. } \\
\text { Inc., } 490 \text { U.S. } 477 \\
\text { (1989). }\end{array}$ & $\begin{array}{l}\text { Agreement to arbitrate claims under the Securities Act was } \\
\text { enforceable. Dissent (Stevens with all), settled interpretation } \\
\text { against arbitration should have prevailed. }\end{array}$ & $\begin{array}{l}\text { S e curiti es, } \\
\text { conservative }\end{array}$ \\
\hline $\begin{array}{l}\text { Finley v. United } \\
\text { States, } 490 \text { U.S. } \\
545(1989) .\end{array}$ & $\begin{array}{l}\text { Dissents (Blackmun; Stevens with Brennan \& Marshall) would } \\
\text { grant jurisdiction over pendent party pendent claim in a federal } \\
\text { tort claim. }\end{array}$ & $\begin{array}{l}\mathrm{T} \text { o } \mathrm{r} \quad \mathrm{t}, \\
\text { conservative }\end{array}$ \\
\hline $\begin{array}{l}\text { W a r d s cove } \\
\text { Packing Co. v. } \\
\text { Atonio, } 490 \text { U.S. } \\
642(1989) \text {. }\end{array}$ & $\begin{array}{l}\text { Majority finds no disparate impact in separate accommodations } \\
\text { for different levels of employees. Dissents (Stevens with all; } \\
\text { Blackmun with Brennan \& Marshall) argue that the majority's } \\
\text { opinion departs from disparate impact precedent. }\end{array}$ & $\begin{array}{l}\mathrm{S} \text { o c i a } 1, \\
\text { conservative }\end{array}$ \\
\hline
\end{tabular}




\begin{tabular}{|c|c|c|}
\hline $\begin{array}{l}\text { Martin v. Wilks, } \\
490 \text { U.S. } 755 \\
(1989) .\end{array}$ & $\begin{array}{l}\text { White firefighters could challenge as discriminatory the } \\
\text { employment decisions made pursuant to prior consent decree. } \\
\text { Dissent (Stevens with Blackmun, Brennan \& Marshall), they } \\
\text { should have intervened in the prior litigation. }\end{array}$ & $\begin{array}{l}\text { S o c i a } 1 \text {, } \\
\text { conservative }\end{array}$ \\
\hline $\begin{array}{l}\text { Will v. Mich. Dep't } \\
\text { of State Police, } 491 \\
\text { U.S. } 58 \text { (1989). }\end{array}$ & $\begin{array}{l}\text { States not subject to liability for civil rights' violations. } \\
\text { Dissents (Brennan with all; Stevens) would explore sovereign } \\
\text { immunity arguments with doubt. }\end{array}$ & $\begin{array}{l}\text { S o c i a } 1 \text {, } \\
\text { conservative }\end{array}$ \\
\hline $\begin{array}{l}\text { Patterson } v . \\
\text { McLean Credit } \\
\text { Union, } 491 \text { U.S. } \\
164 \text { (1989). }\end{array}$ & $\begin{array}{l}\text { Dissent and concurrence (Brennan with Blackmun \& Marshall; } \\
\text { Stevens) would "hold that the Court of Appeals erred in } \\
\text { deciding that petitioner's racial harassment claim is not } \\
\text { cognizable under } \S 1981 \text {. It likewise erred in holding that } \\
\text { petitioner could succeed in her promotion-discrimination claim } \\
\text { only by proving that she was better qualified for the position of } \\
\text { intermediate accounting clerk than the white employee who } \\
\text { was in fact promoted." }\end{array}$ & $\begin{array}{l}\text { S o c i a } 1 \\
\text { conservative }\end{array}$ \\
\hline $\begin{array}{l}\text { Dellmuth v. Muth, } \\
491 \text { U.S. } 223 \\
\text { (1989). }\end{array}$ & $\begin{array}{l}\text { States have sovereign immunity against liability under the } \\
\text { Education of the Handicapped Act. Dissents (Brennan with all; } \\
\text { Blackmun, Stevens) would find that the Act abrogated } \\
\text { sovereign immunity. }\end{array}$ & $\begin{array}{l}\text { S o c i a } 1 \\
\text { conservative }\end{array}$ \\
\hline $\begin{array}{l}\text { Pitt. \& Lake Erie } \\
\text { R.R CO. v. Ry. } \\
\text { Labor Executives' } \\
\text { Ass'n, } 491 \text { U.S. } \\
490 \text { (1989). }\end{array}$ & $\begin{array}{l}\text { Upholding injunction of union's strike against restructuring of } \\
\text { Railroad leading to job losses. Dissent (Stevens with Brennan, } \\
\text { Marshall \& Blackmun) finds majority violates precedent and } \\
\text { established regulation of rails. }\end{array}$ & $\begin{array}{l}\mathrm{L} \text { a b o r , } \\
\text { conservative }\end{array}$ \\
\hline $\begin{array}{l}\text { United States v. } \\
\text { Monsanto, } 491 \\
\text { U.S. } 600(1989) .\end{array}$ & $\begin{array}{l}\text { Asset forfeiture of criminal defendant does not require } \\
\text { allowance for attorney's fees. Dissent (Blackmun with all) } \\
\text { would find provision unconstitutional. }\end{array}$ & $\begin{array}{l}\text { C ri m P r o, } \\
\text { conservative }\end{array}$ \\
\hline $\begin{array}{l}\text { Caplin \& Drysdale } \\
\begin{array}{ll}\text { v. United States, } \\
491 \quad \text { U.S. } 617 \\
(1989) .\end{array}\end{array}$ & Similar to U.S. v Monsanto, 491 U.S. 600. & $\begin{array}{l}\text { C r i m P r o, } \\
\text { conservative }\end{array}$ \\
\hline $\begin{array}{l}\text { Jett v. Dall. Indep. } \\
\text { Sch. Dist., } 491 \text { U.S. } \\
701 \text { (1989). }\end{array}$ & $\begin{array}{l}\text { Dissents (Brennan with all) "would conclude that liability } \\
\text { under } \S 1981 \text { may be predicated on a theory of respondeat } \\
\text { superior." }\end{array}$ & $\begin{array}{l}\text { S o c i a } 1, \\
\text { conservative }\end{array}$ \\
\hline $\begin{array}{l}\text { M u r r a y } \\
\text { Giarratano, } 492 \\
\text { U.S. 1 (1989). }\end{array}$ & $\begin{array}{l}\text { Dissent (Stevens with all) would grant a right to postconviction } \\
\text { state-appointed (free) counsel that the majority denies. }\end{array}$ & $\begin{array}{l}\text { C r i m P r o, } \\
\text { conservative }\end{array}$ \\
\hline $\begin{array}{l}\text { Hoffman v. Conn. } \\
\text { Dep't of Income } \\
\text { Maint., } 492 \text { U.S. } 96 \\
\text { (1989). }\end{array}$ & $\begin{array}{l}\text { Eleventh Amendment bars bankruptcy trustee claims against } \\
\text { state. Dissents (Marshall with all; Stevens with Blackmun) } \\
\text { would find that the Bankruptcy Code abrogated immunity. }\end{array}$ & $\begin{array}{l}\text { Bankruptcy, } \\
\text { conservative }\end{array}$ \\
\hline $\begin{array}{l}\text { Duckworth v. } \\
\text { Eagan, } 492 \text { U.S. } \\
195(1989) .\end{array}$ & $\begin{array}{l}\text { Majority relaxes Miranda warning standards. Dissent (Marshall } \\
\text { with all) would not. }\end{array}$ & $\begin{array}{l}\text { C r i m P r o, } \\
\text { conservative }\end{array}$ \\
\hline $\begin{array}{l}\text { Penry v. Lynaugh, } \\
492 \text { U.S. } 302 \\
(1989) .\end{array}$ & $\begin{array}{l}\text { Partial concurrences would bar the execution of the mentally } \\
\text { retarded. }\end{array}$ & $\begin{array}{l}\text { C r i m P r o, } \\
\text { conservative }\end{array}$ \\
\hline $\begin{array}{l}\text { S t a n for d v. } \\
\text { Kentucky, } 492 \text { U.S. } \\
361 \text { (1989). }\end{array}$ & $\begin{array}{l}\text { Dissent (Brennan with all) would consider unconstitutional the } \\
\text { execution of underage offenders. }\end{array}$ & $\begin{array}{l}\text { C r i m P r o, } \\
\text { conservative }\end{array}$ \\
\hline
\end{tabular}




\begin{tabular}{|c|c|c|}
\hline $\begin{array}{l}\text { Webster v. Reprod. } \\
\text { Health Servs., } 492 \\
\text { U.S. } 490 \text { (1989). }\end{array}$ & $\begin{array}{l}\text { State statute imposing restrictions on abortions is } \\
\text { constitutional. Dissents (Blackmun with Brennan \& Marshall; } \\
\text { Stevens) would not find statute constitutional. }\end{array}$ & $\begin{array}{l}\text { A b o r t i o n, } \\
\text { conservative }\end{array}$ \\
\hline $\begin{array}{l}\text { Spallone v. United } \\
\text { States, } 493 \text { U.S. } \\
265(1990) .\end{array}$ & $\begin{array}{l}\text { Sanctions on city council members who failed to vote for } \\
\text { legislative package to counter discrimination in public housing } \\
\text { was abuse of discretion. Dissent (Brennan with all), Court is } \\
\text { second-guessing district judges. }\end{array}$ & $\begin{array}{l}\text { S o c i a } 1 \\
\text { conservative }\end{array}$ \\
\hline $\begin{array}{l}\text { Holland v. Illinois, } \\
493 \text { U.S. } 474 \\
(1990) \text {. }\end{array}$ & $\begin{array}{l}\text { Prosecutor's racial use of peremptory challenges upheld. } \\
\text { Dissents (Marshall with Brennan \& Blackmun; Stevens), } \\
\text { ignores precedent. }\end{array}$ & $\begin{array}{l}\text { C r i m P r o } \\
\text { conservative }\end{array}$ \\
\hline $\begin{array}{l}\text { B ly st one } \quad \text {. } \\
\text { Pennsylvania, } 494 \\
\text { U.S. } 299(1990) .\end{array}$ & $\begin{array}{l}\text { Dissent (Brennan with all), mandatory death sentence statute } \\
\text { should have been held to violate the "...individualized } \\
\text { sentencing hearing required by the Eighth Amendment." }\end{array}$ & $\begin{array}{l}\text { C r i m P r o } \\
\text { conservative }\end{array}$ \\
\hline $\begin{array}{l}\text { Michigan v. } \\
\text { Harvey, } 494 \text { U.S. } \\
344 \text { (1990). }\end{array}$ & $\begin{array}{l}\text { Majority admits uncounseled statements for impeachment. } \\
\text { Dissent (Stevens with all) would preclude any use of } \\
\text { uncounseled statements. }\end{array}$ & $\begin{array}{l}\text { C r i m P r o, } \\
\text { conservative }\end{array}$ \\
\hline $\begin{array}{l}\text { B o y d e } \quad \mathrm{v} . \\
\text { California, } 494 \\
\text { U.S. } 370(1990) .\end{array}$ & $\begin{array}{l}\text { Dissent (Marshall with all) would find mandatory language of } \\
\text { state's death penalty statute unconstitutional. }\end{array}$ & $\begin{array}{l}\text { C r i m P r o, } \\
\text { conservative }\end{array}$ \\
\hline $\begin{array}{l}\text { Butler v. McKellar, } \\
494 \quad \text { U.S. } 407 \\
(1990) \text {. }\end{array}$ & $\begin{array}{l}\text { Death habeas; reducing retroactivity of new doctrines. Dissent } \\
\text { (Brennan with all), "the Court has finally succeeded in its } \\
\text { thinly veiled crusade to eviscerate Congress' habeas corpus } \\
\text { regime." }\end{array}$ & $\begin{array}{l}\text { n P r o, } \\
\text { ative }\end{array}$ \\
\hline $\begin{array}{l}\text { Saffle v. Parks, } 494 \\
\text { U.S. } 484 \text { (1990). }\end{array}$ & $\begin{array}{l}\text { Death habeas; dissent (Brennan with all), state statute advising } \\
\text { jury to avoid influence of sympathy should have been held } \\
\text { unconstitutional. }\end{array}$ & $\begin{array}{l}\text { C r i m P r o, } \\
\text { conservative }\end{array}$ \\
\hline $\begin{array}{l}\text { C 1 e m o n s } \quad \mathrm{v} . \\
\text { Mississippi, } 494 \\
\text { U.S. } 738(1990) .\end{array}$ & $\begin{array}{l}\text { Dissents (Brennan; Blackmun with all), given that one } \\
\text { aggravating factor was constitutionally invalid, would have not } \\
\text { allowed state supreme court to reweigh mitigating and } \\
\text { aggravating circumstances and uphold the death penalty. }\end{array}$ & $\begin{array}{l}\text { C r i m P r o, } \\
\text { conservative }\end{array}$ \\
\hline $\begin{array}{l}\text { New York v. } \\
\text { Harris, } 495 \text { U.S. } 14 \\
(1990) \text {. }\end{array}$ & $\begin{array}{l}\text { Dissent (Marshall with all) would vacate considering death } \\
\text { penalty cruel and unusual. }\end{array}$ & $\begin{array}{l}\text { C } \mathrm{r} \text { i } \mathrm{m}^{\prime} 1 \\
\text { conservative }\end{array}$ \\
\hline $\begin{array}{l}\text { Delo v. Stokes, } 495 \\
\text { U.S. } 320 \text { (1990). }\end{array}$ & $\begin{array}{l}\text { Dissents (Brennan with Marshall \& Blackmun; Stevens with } \\
\text { Blackmun) would have allowed fourth habeas petition. }\end{array}$ & $\begin{array}{l}\text { C r i m P r o, } \\
\text { conservative }\end{array}$ \\
\hline $\begin{array}{l}\text { Demosthenes v. } \\
\text { Baal, } 495 \text { U.S. } 731 \\
\text { (1990). }\end{array}$ & $\begin{array}{l}\text { Death habeas; dissent (Blackmun with Marshall) would not } \\
\text { have allowed defendant's withdrawal of habeas petition to } \\
\text { override petition by defendant's parents and lead to dismissal } \\
\text { of writ. }\end{array}$ & $\begin{array}{l}\text { C r i m P r o } \\
\text { conservative }\end{array}$ \\
\hline $\begin{array}{l}\text { Am. Trucking } \\
\text { Ass'ns v. Smith, } \\
496 \quad \text { U.S. } 167 \\
(1990) \text {. }\end{array}$ & $\begin{array}{l}\text { Dissent (Stevens with all) would grant retroactivity to decision } \\
\text { interpreting state tax on trucks, past tax was payable. Liberal if } \\
\text { about tax, conservative if about procedural quietude. }\end{array}$ & $\begin{array}{l}\mathrm{T} \quad \mathrm{a} \quad \mathrm{x} \\
\text { conservative }\end{array}$ \\
\hline $\begin{array}{l}\text { Sullivan v. Stroop, } \\
496 \quad \text { U.S. } 478 \\
(1990) \text {. }\end{array}$ & $\begin{array}{l}\text { Dissents (Blackmun with Brennan \& Marshall; Stevens), "the } \\
\text { Court holds that the plain language of a statute applicable by its } \\
\text { terms to 'any child support payments' compels the conclusion } \\
\text { that the statute does not apply to benefits paid to the defendant } \\
\text { child of a disabled, retired, or deceased parent for the express } \\
\text { purpose of supporting that child." }\end{array}$ & $\begin{array}{l}\mathrm{S} \text { o c i a } 1, \\
\text { conservative }\end{array}$ \\
\hline
\end{tabular}




\begin{tabular}{|c|c|c|}
\hline $\begin{array}{l}\text { Sawyer v. Smith, } \\
497 \text { U.S. } 227 \\
(1990) \text {. }\end{array}$ & $\begin{array}{l}\text { Death habeas; no retroactivity to rule about misallocation of } \\
\text { responsibility (Caldwell). Dissent (Marshall with all) disagrees. }\end{array}$ & $\begin{array}{l}\mathrm{C} \text { r i m P r o, } \\
\text { conservative }\end{array}$ \\
\hline $\begin{array}{l}\text { Cruzan v. Dir., Mo. } \\
\text { Dep't of Health, } \\
497 \text { U.S. } 261 \\
(1990) \text {. }\end{array}$ & $\begin{array}{l}\text { Majority denies parents of vegetative patient right to terminate } \\
\text { life support. Dissents (Brennan with Marshall \& Blackmun; } \\
\text { Stevens), this "desecrates the state's responsibility for } \\
\text { protecting life." }\end{array}$ & $\begin{array}{l}\text { S o c i a } 1 \\
\text { conservative }\end{array}$ \\
\hline $\begin{array}{l}\text { Walton v. Arizona, } \\
497 \quad \text { U.S. } 639 \\
(1990) .\end{array}$ & $\begin{array}{l}\text { Death penalty proper. Dissents (Blackmun with Brennan, } \\
\text { Marshall and Stevens; Brennan with Marshall; Stevens), rules } \\
\text { "run afoul of the established Eighth Amendment principle that } \\
\text { a capital defendant is entitled to an individualized sentencing } \\
\text { determination which involves the consideration of all relevant } \\
\text { mitigating evidence." }\end{array}$ & $\begin{array}{l}\mathrm{C} \text { r i m } \mathrm{P} \mathrm{r} \mathrm{o}, \\
\text { conservative }\end{array}$ \\
\hline $\begin{array}{l}\text { United States v. } \\
\text { Kokinda, } 497 \text { U.S. } \\
720(1990) .\end{array}$ & $\begin{array}{l}\text { Dissent (Brennan with all), sidewalk of post office is public } \\
\text { forum allowing solicitation. }\end{array}$ & $\begin{array}{l}\mathrm{S} p \text { e e } \mathrm{c} h \\
\text { conservative }\end{array}$ \\
\hline $\begin{array}{l}\text { Lewis v. Jeffers, } \\
497 \text { U.S. } 764 \\
(1990) .\end{array}$ & $\begin{array}{l}\text { Death habeas; state's "especially heinous" statute was not } \\
\text { unconstitutionally vague. Dissent (Blackmun with all), } \\
\text { language has no limitations in principle and was falsely } \\
\text { applied. }\end{array}$ & $\begin{array}{l}\text { C r i m P r o, } \\
\text { conservative }\end{array}$ \\
\hline $\begin{array}{l}\text { Lujan v. Nat'1 } \\
\text { Wildlife Fed'n, } 497 \\
\text { U.S. } 871 \text { (1990). }\end{array}$ & $\begin{array}{l}\text { Advocacy organization has no standing to challenge } \\
\text { environmental determinations. Dissent (Blackmun with all), } \\
\text { NWF has standing. }\end{array}$ & $\begin{array}{l}\text { E n v i r } 1 \text {, } \\
\text { conservative }\end{array}$ \\
\hline
\end{tabular}

\section{BLACKMUN-BRENNAN-MARSHALL-O'CONNOR-STEVENS (EIGHT O'CLOCK)}

\begin{tabular}{|l|l|l|}
\hline $\begin{array}{l}\text { S u ll iva n v. } \\
\text { Hudson, 490 U.S. } \\
877 \text { (1989). }\end{array}$ & $\begin{array}{l}\text { Majority allows attorney's fees for social security claimant. } \\
\text { Dissent (White with all) would not for proceedings on remand; } \\
\text { statutory interpretation. }\end{array}$ & Social, liberal \\
\hline $\begin{array}{l}\text { B r e n d a le v. } \\
\text { C o n fe d e r a t e d } \\
\text { Tribes \& Bands of } \\
\text { Yakima Indian } \\
\text { Nation, 492 U.S. } \\
\text { 408 (1989). }\end{array}$ & $\begin{array}{l}\text { Zoning regulation of fee land inside reservation; plurality } \\
\text { not subject it to the tribe. }\end{array}$ & Tribal, liberal \\
\hline $\begin{array}{l}\text { Cty. of Allegheny } \\
\text { v. ACLU, 492 U.S. } \\
573 \text { (1989). }\end{array}$ & $\begin{array}{l}\text { Establishment of religion. Plurality disallows display of creche } \\
\text { and menorah; partial dissents would allow it. }\end{array}$ & $\begin{array}{l}\text { Establishment, } \\
\text { liberal }\end{array}$ \\
\hline $\begin{array}{l}\text { H o d g s o n v . } \\
\text { Minnesota, 497 }\end{array}$ & $\begin{array}{l}\text { Abortion. Plurality affirms upholding of parental notification } \\
\text { before abortions under age 18 subject to judicial bypass; } \\
\text { dissents would not. }\end{array}$ & Abortion, liberal \\
\hline
\end{tabular}

\section{Appendix B7: Tables of Breyer Composition Majorities Producing More than Two 5-4 Opinions}

We list the opinions of the United States Supreme Court while its composition is defined by its junior justice being Breyer. The Breyer composition consists of two appointees of Democratic presidents (Breyer and Ginsburg) and seven appointees of Republican presidents (Kennedy, O'Connor, Rehnquist, Scalia, Souter, Stevens, and Thomas). We list the majorities as they appear in the 
corresponding figure in the full-text proceeding clockwise from the nine o'clock position. The name of the case, along with the citation to the United States Reporter, and the year appears in the first column. The second column holds our brief description of the outcome compared to the dissent's position. The third column holds the legal field and the political slant of the majority's position as it arises by juxtaposition to that of the minority. We sort the justices in the majorities by, first, the chief justice, then the associate justices by alphabetical order.

\section{BREYER-GinSBURG-O'CONNOR-SOUTER-STEVENS (NINE O'ClOCK)}

\begin{tabular}{|c|c|c|}
\hline 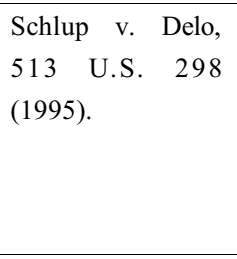 & $\begin{array}{l}\text { Plurality; death habeas; majority applies more lenient standard } \\
\text { in repeated habeas miscarriage of justice claim. Dissent } 1 \\
\text { (Rehnquist with Kennedy \& Thomas), court "both waters down } \\
\text { the standard suggested in that case, and will inevitably create } \\
\text { confusion in the lower courts." Dissent } 2 \text { (Scalia with Thomas), } \\
\text { contrary to statute. }\end{array}$ & CrimPro, liberal \\
\hline $\begin{array}{l}\text { Kyles v. Whitley, } \\
514 \text { U.S. } 419 \\
(1995) \text {. }\end{array}$ & $\begin{array}{l}\text { Plurality; death habeas; evidence undisclosed by the } \\
\text { prosecution entitles def to new trial. Dissent (Scalia with all), } \\
\text { no disagreement about law, certiorari should not have been } \\
\text { granted, uphold lower courts. }\end{array}$ & CrimPro, liberal \\
\hline $\begin{array}{l}\text { M o r s e v. } \\
\text { Republican Party } \\
\text { of Va., } 517 \text { U.S. } \\
186(1996) \text {. }\end{array}$ & $\begin{array}{l}\text { Challenge to party's senator nomination procedure; plurality: } \\
\text { voting rights act requires preclearance. Dissent } 1 \text { (Scalia with } \\
\text { Thomas), party issue, party has First Amendment right. Dissent } \\
2 \text { (Kennedy with Rehnquist), no state action. Dissent } 3 \\
\text { (Thomas with all), party is not a subdivision of state. }\end{array}$ & Voting, liberal \\
\hline $\begin{array}{l}\text { L o n c h a r v. } \\
\text { Thomas, } 517 \text { U.S. } \\
314 \text { (1996). }\end{array}$ & $\begin{array}{l}\text { Death habeas; Court of appeals vacated stay of execution; } \\
\text { majority reverses. Dissent (Rehnquist with all) would only } \\
\text { reverse the order vacating the stay, habeas delays problematic. }\end{array}$ & Criml, liberal \\
\hline $\begin{array}{l}\text { Lindh v. Murphy, } \\
521 \text { U.S. } 320 \\
(1997) \text {. }\end{array}$ & $\begin{array}{l}\text { Non-capital habeas; amendments did not apply retroactively. } \\
\text { Dissent (Rehnquist with all), court disregards retroactivity } \\
\text { caselaw. }\end{array}$ & CrimPro, liberal \\
\hline $\begin{array}{l}\text { Richardson } \mathrm{v} . \\
\text { McKnight, } 521 \\
\text { U.S. } 399 \text { (1997). }\end{array}$ & $\begin{array}{l}\text { Prison guard employees of a private prison management firm } \\
\text { are not entitled to qualified immunity from } \S 1983 \text {. Dissent } \\
\text { (Scalia with all), "This holding is supported neither by } \\
\text { common-law tradition nor public policy, and contradicts our } \\
\text { settled practice of determining } \S 1983 \text { immunity on the basis } \\
\text { of the public function being performed." }\end{array}$ & Criml, liberal \\
\hline $\begin{array}{l}\text { Gray v. Maryland, } \\
523 \text { U.S. } 185 \\
\text { (1998). }\end{array}$ & $\begin{array}{l}\text { Cannot use confession of codefendant even with name of } \\
\text { defendant blank. Dissent (Scalia with all) argues against } \\
\text { expanded suppression. }\end{array}$ & CrimPro, liberal \\
\hline $\begin{array}{l}\text { Minn. v. Mille } \\
\text { Lacs Band of } \\
\text { Chippewa Indians, } \\
526 \text { U.S. } 172 \\
(1999) \text {. }\end{array}$ & $\begin{array}{l}\text { Indian tribe retains usufructuary rights to its lands. Dissent } \\
\text { (Rehnquist with all), "To reach this result, the Court must } \\
\text { successively conclude that: (1) an } 1850 \text { Executive Order } \\
\text { explicitly revoking the privilege as authorized by the } 1837 \\
\text { Treaty was unlawful; (2) an } 1855 \text { Treaty under which certain } \\
\text { Chippewa Bands ceded 'all' interests to the land does not } \\
\text { include the treaty right to come onto the land and hunt; and (3) } \\
\text { the admission of Minnesota into the Union in } 1858 \text { did not } \\
\text { terminate the discretionary hunting privilege, despite } \\
\text { established precedent of this Court to the contrary." }\end{array}$ & Tribal, liberal \\
\hline
\end{tabular}




\begin{tabular}{|c|c|c|}
\hline $\begin{array}{l}\text { Davis v. Monroe } \\
\text { County Bd. of } \\
\text { Educ., } 526 \text { U.S. } \\
629(1999) .\end{array}$ & $\begin{array}{l}\text { School board can be liable under Title IX for sexual } \\
\text { harassment between students. Dissent (Kennedy with all), "the } \\
\text { Court must not imply a private cause of action for damages } \\
\text { unless it can demonstrate that the congressional purpose to } \\
\text { create the implied cause of action is so manifest that the State, } \\
\text { when accepting federal funds, had clear notice of the terms and } \\
\text { conditions of its monetary liability." }\end{array}$ & Social, liberal \\
\hline $\begin{array}{l}\text { West v. Gibson, } \\
527 \text { U.S. } 212 \\
(1999) \text {. }\end{array}$ & $\begin{array}{l}\text { EEOC has authority to award compensatory damages for } \\
\text { discrimination. Dissent (Kennedy with all), "The rules } \\
\text { governing waivers of sovereign immunity make clear that the } \\
\text { Equal Employment Opportunity Commission (EEOC) may not } \\
\text { award or authorize compensatory damages against the United } \\
\text { States unless it is permitted to do so by a statutory provision } \\
\text { which waives the United States' immunity" }\end{array}$ & Social, liberal \\
\hline $\begin{array}{l}\text { S t e nberg } \mathrm{v} . \\
\text { Carhart, } 530 \text { U.S. } \\
914(2000) .\end{array}$ & $\begin{array}{l}\text { Plurality: Nebraska partial birth abortion statute } \\
\text { unconstitutional because it had no exception for mother's } \\
\text { health. Dissents (Rehnquist; Scalia; Kennedy with Rehnquist; } \\
\text { Thomas with Scalia \& Rehnquist) disagree. }\end{array}$ & Abortion, libera \\
\hline $\begin{array}{l}\text { Brentwood Acad. } \\
\text { v. Tenn. Secondary } \\
\text { Sch. Athletic Ass'n, } \\
531 \text { U.S. } 288 \\
(2001) .\end{array}$ & $\begin{array}{l}\text { State High School Athletic Association is state actor for First } \\
\text { Amendment grounds. Dissent (Thomas with all), "We have } \\
\text { never found state action based upon mere 'entwinement."' }\end{array}$ & Speech, liberal \\
\hline $\begin{array}{l}\text { E a s } 1 \text { e y } \quad \mathrm{v} . \\
\text { Cromartie, } 532 \\
\text { U.S. } 234(2001)\end{array}$ & $\begin{array}{l}\text { Majority: That redistricting was driven by race rather than } \\
\text { politics was clearly erroneous. Dissent (Thomas with all), not } \\
\text { clearly erroneous. Revisiting of Hunt v. Cromartie, } 526 \text { US } 541 \\
\text { (1999) of main conservative majority with concurrences (hence } \\
\text { filter does not catch it) by the standard minority which here } \\
\text { also gets O'Connor's vote. }\end{array}$ & Voting, liberal \\
\hline $\begin{array}{l}\text { Idaho v. United } \\
\text { States, } 533 \text { U.S. } \\
262(2001) .\end{array}$ & $\begin{array}{l}\text { Title of tribe to submerged lands to continue (State does not get } \\
\text { them). Dissent (Rehnquist with all), "the existence of [Indian- } \\
\text { title-preserving] intent on the part of the Executive Branch is } \\
\text { simply not enough to defeat an incoming State's title to } \\
\text { submerged lands within its borders. Decisions of this Court } \\
\text { going back more than } 150 \text { years establish this proposition } \\
\text { beyond a shadow of a doubt." }\end{array}$ & Tribal, liberal \\
\hline $\begin{array}{l}\text { Fed. Election } \\
\text { Comm'n v. Colo. } \\
\text { Republican Fed. } \\
\text { Campaign Comm., } \\
533 \text { U.S. } 431 \\
(2001) \text {. }\end{array}$ & $\begin{array}{l}\text { Federal Election commission limits on funding consistent with } \\
\text { First Amendment. Dissent (Thomas with all), "The Party } \\
\text { Expenditure Provision, } 2 \text { U.S.C. } \S 441 \mathrm{a}(\mathrm{d})(3) \text {, severely limits } \\
\text { the amount of money that a national or state committee of a } \\
\text { political party can spend in coordination with its own candidate } \\
\text { for the Senate or House of Representatives. . . Because this } \\
\text { provision sweeps too broadly, interferes with the party- } \\
\text { candidate relationship, and has not been proved necessary to } \\
\text { combat corruption, I respectfully dissent." }\end{array}$ & Speech, liberal \\
\hline $\begin{array}{l}\text { Zadvydas v. Davis, } \\
533 \text { U.S. } 678 \\
(2001) .\end{array}$ & $\begin{array}{l}\text { Alien habeas past } 90 \text {-day removal confinement; majority: } \\
\text { presumptive limit to reasonable duration of post-removal- } \\
\text { period detention is six months. Dissent } 1 \text { (Scalia with } \\
\text { Thomas),criminal aliens cannot have a right to be released. } \\
\text { Dissent } 2 \text { (Kennedy with all), no time limit in statute. }\end{array}$ & Social, liberal \\
\hline
\end{tabular}




\begin{tabular}{|c|c|c|}
\hline $\begin{array}{l}\text { Kelly v. South } \\
\text { Carolina, } 534 \text { U.S. } \\
246(2002) .\end{array}$ & $\begin{array}{l}\text { Death habeas; trial refused instruction about ineligibility for } \\
\text { parole in case of life without parole because prison knife and } \\
\text { escape plans presented to jury were about character, not } \\
\text { dangerousness; majority: was entitled to ineligibility } \\
\text { instruction. Dissent } 1 \text { (Rehnquist with Kennedy), "no } \\
\text { connection with the due process rationale of Simmons." } \\
\text { Dissent } 2 \text { (Thomas with Scalia), no Simmons right to begin } \\
\text { with. }\end{array}$ & CrimPro, liberal \\
\hline $\begin{array}{l}\text { A } 1 \text { a b a m a } \mathrm{v} . \\
\text { Shelton, } 535 \text { U.S. } \\
654 \text { (2002). }\end{array}$ & $\begin{array}{l}\text { Even probation conviction entitles to counsel. Dissent (Scalia } \\
\text { with all), precedent required imprisonment. }\end{array}$ & CrimPro, liberal \\
\hline $\begin{array}{l}\text { Carey v. Saffold, } \\
536 \text { U.S. } 214 \\
(2002) \text {. }\end{array}$ & $\begin{array}{l}\text { Habeas limitation tolled for state collateral review, remand to } \\
\text { ask for unreasonable state delay. Dissent (Kennedy with all), } \\
\text { no appeal was filed, majority is making stuff up. }\end{array}$ & CrimPro, liberal \\
\hline $\begin{array}{l}\text { Rush Prudential } \\
\text { HMO, Inc., v. } \\
\text { Moran, } 536 \text { U.S. } \\
355 \text { (2002). }\end{array}$ & $\begin{array}{l}\text { IL system of arbitrating health coverage was in harmony with } \\
\text { ERISA. Dissent (Thomas with all), "not only conflicts with our } \\
\text { precedents, it also eviscerates the uniformity of ERISA } \\
\text { remedies." }\end{array}$ & Health, liberal \\
\hline $\begin{array}{l}\text { United States v. } \\
\text { White Mountain } \\
\text { Apache Tribe, } 537 \\
\text { U.S. } 465 \text { (2003). }\end{array}$ & $\begin{array}{l}\text { Court of Claims has jurisdiction over Apache tribe's claim, no } \\
\text { immunity. Dissent (Thomas with all), statute did not grant } \\
\text { claim v US. }\end{array}$ & Tribal, liberal \\
\hline $\begin{array}{l}\text { Brown v. Legal } \\
\text { Found. of Wash., } \\
538 \text { U.S. } 216 \\
(2003) \text {. }\end{array}$ & $\begin{array}{l}\text { WA had right to require deposits into IOLTA accounts the } \\
\text { interest of which pays for legal services, no taking. Dissent } 1 \\
\text { (Scalia with all), is taking. Dissent } 2 \text { (Kennedy), forced support } \\
\text { of political cause violates First Amendment. }\end{array}$ & Social, liberal \\
\hline $\begin{array}{l}\text { G r u t t e r v. } \\
\text { Bollinger, } 539 \text { U.S. } \\
306(2003) \text {. }\end{array}$ & $\begin{array}{l}\text { School had compelling interest to diversity, justifying } \\
\text { affirmative action. Four dissents: no. }\end{array}$ & Social, liberal \\
\hline $\begin{array}{l}\text { Stogner v. Cal., } \\
539 \text { U.S. } 607 \\
(2003) .\end{array}$ & $\begin{array}{l}\text { CA child abuse law enabling prosecutions of time-lapsed } \\
\text { claims is ex post facto law. Dissent (Kennedy with all), "A law } \\
\text { which does not alter the definition of the crime but only revives } \\
\text { prosecution does not make the crime 'greater than it was, when } \\
\text { committed."' }\end{array}$ & CrimPro, liberal \\
\hline $\begin{array}{l}\text { Alaska Dep't of } \\
\text { E n v t } 1 . \\
\text { Conservation v. } \\
\text { EPA, } 540 \text { U.S. } 461 \\
(2004) \text {. }\end{array}$ & $\begin{array}{l}\text { Environmental, allows EPA to block state agreement with } \\
\text { mine. Dissent (Kennedy with all), "The Court errs, in my } \\
\text { judgment, by failing to hold that EPA, based on nothing more } \\
\text { than its substantive disagreement with the State's discretionary } \\
\text { judgment, exceeded its powers." }\end{array}$ & Envir'l, liberal \\
\hline $\begin{array}{l}\text { Groh v. Ramirez, } \\
540 \quad \text { U.S. } 551 \\
(2004) \text {. }\end{array}$ & $\begin{array}{l}\text { BATF warrant not specifying weapons to be seized was } \\
\text { defective and gave } 1983 \text { claim, no immunity. Dissent } 1 \\
\text { (Kennedy with Rehnquist), officer should receive immunity. } \\
\text { Dissent } 2 \text { (Thomas with Scalia \& Rehnquist), the warrant may } \\
\text { have been faulty, but the search was not unreasonable. }\end{array}$ & CrimPro, liberal \\
\hline $\begin{array}{l}\text { Tennessee v. Lane, } \\
541 \text { U.S. } 509 \\
(2004) .\end{array}$ & $\begin{array}{l}\text { ADA claim against state for access to courts valid. Dissent } 1 \\
\text { (Rehnquist with Kennedy \& Thomas), precedent gives states } \\
\text { Eleventh Amendment immunity. Dissent } 2 \text { (Scalia), no } \\
\text { constitutional violation being remedied, therefore immunity. } \\
\text { Dissent } 3 \text { (Thomas), this is about more than access to courts. }\end{array}$ & Social, liberal \\
\hline
\end{tabular}




\begin{tabular}{|l|l|l|}
\hline $\begin{array}{l}\text { Hibbs v. Winn, 542 } \\
\text { U.S. 88 (2004). }\end{array}$ & $\begin{array}{l}\text { Allows challenge to state tax credit for tuition organizations } \\
\text { over Tax Injunction Act. Dissent (Kennedy with all), TIA bars } \\
\text { it. }\end{array}$ & Social, liberal \\
\hline $\begin{array}{l}\text { J a c k s o n v. } \\
\text { Birmingham Bd. of } \\
\text { Educ., 544 U.S. } \\
\text { 167 (2005). }\end{array}$ & $\begin{array}{l}\text { Women's coach at high school had retaliation claim for being } \\
\text { dismissed for complaining of sex discrimination in funding of } \\
\text { team. Dissent (Thomas with all), private right of action under } \\
\text { title IX does not include claims for retaliation. }\end{array}$ & Social, liberal \\
\hline $\begin{array}{l}\text { Rompilla v. Beard, } \\
545 \text { U.S. 374 } \\
(2005) .\end{array}$ & $\begin{array}{l}\text { Death habeas, finds ineffective assistance of counsel in not } \\
\text { using mitigating childhood and mental issues. Dissent } \\
\text { Kennedy with all), seasoned professionals (two defense } \\
\text { attorneys and three psychologists) not incompetent plus state } \\
\text { courts not unreasonable. }\end{array}$ & \\
\hline $\begin{array}{l}\text { McCreary County, } \\
\text { Ky., v. ACLU of }\end{array}$ & $\begin{array}{l}\text { No display of ten commandments in courthouses. Dissent } \\
\text { (Scalia with all), "the Court's oft repeated assertion that the } \\
\text { Ky., 545 U.S. 844 } \\
\text { government cannot favor religious practice is false; . . today's } \\
\text { opinion extends the scope of that falsehood even beyond prior } \\
\text { cases; ... even on the basis of the Court's false assumptions the } \\
\text { judgment here is wrong." }\end{array}$ & \\
\hline
\end{tabular}

\section{BREYER-GinsBuRG-KENNEDY-SOUTER-STEVENS (TEN O ‘LOCK)}

\begin{tabular}{|c|c|c|}
\hline $\begin{array}{l}\text { Hess v. Port Auth. } \\
\text { Trans-Hu d s on } \\
\text { Corp., } 513 \text { U.S. } 30 \\
\text { (1994). }\end{array}$ & $\begin{array}{l}\text { Port Authority train (PATH) not entitled to Eleventh } \\
\text { Amendment immunity from employees' claims. Dissent } \\
\text { (O'Connor with all), PATH has immunity from Eleventh } \\
\text { Amendment. }\end{array}$ & $\begin{array}{l}\text { F e d e r a } 1 \text { is } \mathrm{m}, \\
\text { liberal }\end{array}$ \\
\hline $\begin{array}{l}\text { U.S. Term Limits, } \\
\text { Inc., v. Thornton, } \\
514 \text { U.S. } 779 \\
(1995) .\end{array}$ & $\begin{array}{l}\text { Plurality: Arkansas Constitution may not impose additional } \\
\text { qualification requirements for US offices (term limits). } \\
\text { Dissent (Thomas with all), "Contrary to the majority's } \\
\text { suggestion, the people of the States need not point to any } \\
\text { affirmative grant of power in the Constitution in order to } \\
\text { prescribe qualifications for their representatives in Congress." }\end{array}$ & Voting, liberal \\
\hline $\begin{array}{l}\text { Holly Farms Corp. } \\
\text { v. NLRB, } 517 \text { U.S. } \\
392 \text { (1996). }\end{array}$ & $\begin{array}{l}\text { Poultry challenges union's and NLRB's determination that } \\
\text { live-haul workers and chicken-catchers \&c are not exempt } \\
\text { agricultural workers; majority: union wins. Dissent } \\
\text { (O'Connor with all), chicken-catchers are agricultural. }\end{array}$ & $\begin{array}{l}\text { Employment, } \\
\text { liberal }\end{array}$ \\
\hline $\begin{array}{l}\text { Medtronic, Inc., v. } \\
\text { Lohr, } 518 \text { U.S. } 470 \\
\text { (1996). }\end{array}$ & $\begin{array}{l}\text { Medical Device statute does not preclude similar state law } \\
\text { claims. Dissent (O'Connor with all), "state common-law } \\
\text { damages actions ... are preempted." }\end{array}$ & $\begin{array}{l}\text { F e d e r a } 1 \text { i s m, } \\
\text { liberal }\end{array}$ \\
\hline $\begin{array}{l}\text { Denver Area Educ. } \\
\mathrm{T} \text { e } 1 \text { e c o m m. } \\
\text { Consortium, Inc., } \\
\text { v. FCC, } 518 \text { U.S. } \\
727 \text { (1996). }\end{array}$ & $\begin{array}{l}\text { Plurality on First Amendment on cable TV. Dissent } 1 \\
\text { (O'Connor), protect children by allowing cable to not transmit } \\
\text { indecent material. Dissent } 2 \text { (Thomas with Rehnquist \& } \\
\text { Scalia), cable should enjoy freedoms of print media and not } \\
\text { be obligated to carry others. }\end{array}$ & Speech, liberal \\
\hline
\end{tabular}




\begin{tabular}{|c|c|c|}
\hline $\begin{array}{l}\text { Old Chief v. United } \\
\text { States, } 519 \text { U.S. } \\
172 \text { (1997). }\end{array}$ & $\begin{array}{l}\text { Dissent (O'Connor with all), "I do not agree that the } \\
\text { Government's introduction of evidence that reveals the name } \\
\text { and basic nature of a defendant's prior felony conviction in a } \\
\text { prosecution brought under } 18 \text { U.S.C. } \S 922(\mathrm{~g})(1) \text { 'unfairly' } \\
\text { prejudices the defendant within the meaning of Rule } 403 \text {. Nor } \\
\text { do I agree with the Court's newly minted rule that a defendant } \\
\text { charged with violating } \S 922(\mathrm{~g})(1) \text { can force the Government } \\
\text { to accept his concession to the prior conviction element of } \\
\text { that offense, thereby precluding the Government from } \\
\text { offering evidence on this point." }\end{array}$ & CrimPro, liberal \\
\hline $\begin{array}{l}\text { Crawford-El v. } \\
\text { Britton, } 523 \text { U.S. } \\
574 \text { (1998). }\end{array}$ & $\begin{array}{l}\text { Prisoner bringing } \S 1983 \text { against guard misdelivering legal } \\
\text { papers need not prove with clear and convincing evidence } \\
\text { bad motive to avoid summary judgment. Dissent } 1 \text { (Rehnquist } \\
\text { with O'Connor), "a government official who is a defendant in } \\
\text { a motive-based tort suit is entitled to immunity from suit so } \\
\text { long as he can offer a legitimate reason for the action that is } \\
\text { being challenged, and the plaintiff is unable to establish, by } \\
\text { reliance on objective evidence, that the offered reason is } \\
\text { actually a pretext." Dissent } 2 \text { (Scalia with Thomas), no } \\
\text { exception for pretext because "no 'intent-based' constitutional } \\
\text { tort would have been actionable under the } \S 1983 \text { that } \\
\text { Congress enacted." }\end{array}$ & Admin, liberal \\
\hline $\begin{array}{l}\text { Hohn v. United } \\
\text { States, } 524 \text { U.S. } \\
\text { 236 (1998). }\end{array}$ & $\begin{array}{l}\text { Majority: court has jurisdiction to hear appeals from denials } \\
\text { of certificates of appealability for repeated habeas petitions. } \\
\text { Dissent (Scalia with all), "Today's opinion permits review } \\
\text { where Congress, with unmistakable clarity, has denied it." }\end{array}$ & CrimPro, liberal \\
\hline $\begin{array}{l}\text { Bragdon v. Abbott, } \\
524 \quad \text { U.S. } \quad 624 \\
(1998) .\end{array}$ & $\begin{array}{l}\text { HIV patient claims ADA protection against dentist refusing } \\
\text { treatment, patient wins. Dissent } 1 \text { (Rehnquist with all), } \\
\text { asymptomatic means no disability. Dissent } 2 \text { (O'Connor), no } \\
\text { need to get into difficulties with childbearing, major activities } \\
\text { unimpaired. }\end{array}$ & Business, liberal \\
\hline $\begin{array}{l}\text { Nat'l Fed'n of Fed. } \\
\text { Emps., Local } 1309 \\
\text { v. Dep't of the } \\
\text { Interior, } 526 \text { U.S. } \\
86 \text { (1999). }\end{array}$ & $\begin{array}{l}\text { Majority remands to Agency to determine if midterm } \\
\text { collective bargaining is required by statute. Dissent } \\
\text { (O'Connor with all) "erroneously concludes that when an } \\
\text { agency responds to a judicial decision by abandoning its own } \\
\text { interpretation of a statute and adopting that of the judicial } \\
\text { forum this Court should defer to the agency's revised } \\
\text { position, rather than evaluate whether the revised } \\
\text { interpretation renders, in fact, the most plausible reading of } \\
\text { the statute." }\end{array}$ & $\begin{array}{l}\text { Employment, } \\
\text { liberal }\end{array}$ \\
\hline $\begin{array}{l}\text { Mitchell v. United } \\
\text { States, } 526 \text { U.S. } \\
314 \text { (1999). }\end{array}$ & $\begin{array}{l}\text { Majority: "plea is not a waiver of the privilege [against self- } \\
\text { incrimination] at sentencing." Dissent (Scalia with all), "she } \\
\text { did not have the right to have the sentencer abstain from } \\
\text { making the adverse inferences that reasonably flow from her } \\
\text { failure to testify." }\end{array}$ & CrimPro, liberal \\
\hline $\begin{array}{lcc}\text { NASA } & \text { v. } & \text { Fed. } \\
\text { Labor } & \text { Relations } \\
\text { Auth., } 527 & \text { U.S. } \\
229(1999) . & \end{array}$ & $\begin{array}{l}\text { NASA's Office of Inspector General had to grant employee's } \\
\text { request to be represented by union at interview. Dissent } \\
\text { (Thomas with all), inspectors do not represent management } \\
\text { hence no representation right arises. }\end{array}$ & $\begin{array}{l}\text { Employment, } \\
\text { liberal }\end{array}$ \\
\hline
\end{tabular}




\begin{tabular}{|c|c|c|}
\hline $\begin{array}{l}\text { Legal Serv. Corp. } \\
\text { v. Velazquez, } 531 \\
\text { U.S. } 533(2001) \text {. }\end{array}$ & $\begin{array}{l}\text { Congressional restriction on funding of Legal Services } \\
\text { prohibiting challenges seeking to increase funding to Legal } \\
\text { Services violates First Amendment viewpoint discrimination. } \\
\text { Dissent (Scalia with all), funding law does not regulate } \\
\text { speech and even if unconstitutional should explore } \\
\text { severability. }\end{array}$ & Social, liberal \\
\hline $\begin{array}{l}\text { INS v. St. Cyr, } 533 \\
\text { U.S. } 289 \text { (2001). }\end{array}$ & $\begin{array}{l}\text { Immigration habeas; repeal of discretionary relief } \\
\text { inapplicable retroactively to alien who pled. Dissent (Scalia } \\
\text { with all) Supreme Court has no jurisdiction, result of majority } \\
\text { creates delays in law designed to expedite removal. }\end{array}$ & $\begin{array}{l}\text { Immigration, } \\
\text { liberal }\end{array}$ \\
\hline $\begin{array}{l}\text { Calcano-Martinez } \\
\text { v. INS, } 533 \text { U.S. } \\
348 \text { (2001). }\end{array}$ & Similar to St Cyr, 533 U.S. 289. & $\begin{array}{l}\text { Immigration, } \\
\text { liberal }\end{array}$ \\
\hline $\begin{array}{l}\text { Miss o u ri v. } \\
\text { Seibert., } 542 \text { U.S. } \\
600(2004) \text {. }\end{array}$ & $\begin{array}{l}\text { Plurality: Mid-interrogation confession before Miranda } \\
\text { warnings suppressed even though it was repeated after. } \\
\text { Dissent (O'Connor with all), we rejected this theory in Elstad. }\end{array}$ & CrimPro, liberal \\
\hline $\begin{array}{l}\text { Roper v. Simmons, } \\
543 \quad \text { U.S. } \quad 551 \\
(2005) \text {. }\end{array}$ & $\begin{array}{l}\text { Plurality: No death penalty for under } 18 \text {. Dissent } 1 \\
\text { (O'Connor,) unjustified. Dissent } 2 \text { (Scalia with Rehnquist \& } \\
\text { Thomas), has the constitution really changed in fifteen years? }\end{array}$ & CrimPro, liberal \\
\hline $\begin{array}{l}\text { Kelo v. City of } \\
\text { New London, } \\
\text { Conn., } 545 \text { U.S. } \\
469(2005) .\end{array}$ & $\begin{array}{l}\text { Plurality: Eminent domain condemnation for economic } \\
\text { development fits public use. Dissent } 1 \text { (O'Connor with all), } \\
\text { "Under the banner of economic development, all private } \\
\text { property is now vulnerable to being taken and transferred to } \\
\text { another private owner." Dissent } 2 \text { (Thomas), "shift in } \\
\text { phraseology enables the Court to hold, against all common } \\
\text { sense, that a costly urban-renewal project whose stated } \\
\text { purpose is a vague promise of new jobs and increased tax } \\
\text { revenue" justifies a taking. }\end{array}$ & Takings, liberal \\
\hline
\end{tabular}

\section{GinSBURG-SCALIA-SOUTER-STEVENS-ThOMAS (ELEVEN O'ClOCK)}

\begin{tabular}{|l|l|l|}
\hline $\begin{array}{l}\text { Jones v. United } \\
\text { States, 526 U.S. } \\
227(1999) .\end{array}$ & $\begin{array}{l}\text { Precursor to Apprendi, aggravators are elements of the crime } \\
\text { to be considered by the jury. 530 U.S. 466. Dissent disagrees. }\end{array}$ & CrimPro, liberal \\
\hline $\begin{array}{l}\text { Apprendi v. New } \\
\text { Jersey, 530 U.S. } \\
466(2000) .\end{array}$ & $\begin{array}{l}\text { Aggravating facts must be found beyond a reasonable doubt } \\
\text { by the jury. Dissent disagrees. }\end{array}$ & CrimPro, liberal \\
\hline $\begin{array}{l}\text { Norfolk \& W. Ry. } \\
\text { Co. v. Ayers, 538 }\end{array}$ & $\begin{array}{l}\text { Asbestosis victims can recover under Federal Employers' } \\
\text { Liability Act. Dissent would not award damages for fear of } \\
\text { Uetting cancer. }\end{array}$ & Tort, liberal \\
\hline $\begin{array}{l}\text { B 1 a k e 1 y v } \text { v. } \\
\text { Washington, 542 }\end{array}$ & $\begin{array}{l}\text { Majority applies Apprendi to aggravating factor for states. } \\
\text { 530 U.S. 466. Dissent considers application to be }\end{array}$ & CrimPro, liberal \\
U.S. 296 (2004). & undermining states' efforts at standardized sentencing. & \\
\hline $\begin{array}{l}\text { United States v. } \\
\text { Booker, 543 U.S. }\end{array}$ & $\begin{array}{l}\text { Majority applies Apprendi to aggravating factor for federal } \\
\text { crimes. 530 U.S. 466. Dissent would allow the court, not the } \\
\text { 220 (2005). }\end{array}$ & CrimPro, liberal \\
\hline
\end{tabular}




\section{REHNQUIST-GINSBURG-KENNEDY-SCALIA-THOMAS (ONE O'ClOCK)}

\begin{tabular}{|l|l|l|}
\hline $\begin{array}{l}\text { M o n t a n a v. } \\
\text { Egelhoff, 518 U.S. } \\
37 \text { (1996). }\end{array}$ & $\begin{array}{l}\text { Montana's prohibition of consideration of voluntary } \\
\text { intoxication does not offend due process. Dissent would retry } \\
\text { with that evidence mitigating. }\end{array}$ & $\begin{array}{l}\text { C r i m P r o , } \\
\text { conservative }\end{array}$ \\
\hline $\begin{array}{l}\text { Nat'l Credit Union } \\
\text { Admin. v. First }\end{array}$ & $\begin{array}{l}\text { Bankers can sue Credit Union Admin to prevent approval of } \\
\text { expanded customer base. Dissent argues loss of customers } \\
\text { Nat'l Bank \& Trust } \\
\text { sould not give standing to challenge group definition of } \\
\text { credit union regulation. }\end{array}$ & $\begin{array}{l}\text { A d } \text { m i n .S. } 479 \\
\text { conservative }\end{array}$ \\
(1998). & $\begin{array}{l}\text { Mot having informed consulate does not require retrial. } \\
\text { 544 U.S. 660 } \\
\text { (2005). }\end{array}$ & $\begin{array}{l}\text { C r i m P r o , } \\
\text { conservative }\end{array}$ \\
\hline
\end{tabular}

\section{REHNQUIST-KENNEDY-O'CONNOR-SCALIA-THOMAS (THREE O'CLOCK)}

\begin{tabular}{|c|c|c|}
\hline $\begin{array}{l}\text { United States v. } \\
\text { Lopez, } 514 \text { U.S. } \\
549(1995) .\end{array}$ & $\begin{array}{l}\text { Plurality: Gun-free zones exceed commerce power. Dissent } \\
1 \text { (Stevens), no, commerce depends on education. Dissent } 2 \\
\text { (Souter), meets rational basis, which is test. Dissent } 3 \text { (Breyer } \\
\text { with all), meets traditional commerce clause test. }\end{array}$ & $\begin{array}{l}\text { Gun rights, } \\
\text { conservative }\end{array}$ \\
\hline $\begin{array}{l}\text { M i s s o u r i } \mathrm{v} \text {. } \\
\text { Jenkins, } 515 \text { U.S. } \\
70 \text { (1995). }\end{array}$ & $\begin{array}{l}\text { Invalidating orders of district court attempting to desegregate } \\
\text { Missouri school. Dissent (Souter with all), "overrule[s] a } \\
\text { unanimous constitutional precedent of } 20 \text { years' standing, } \\
\text { which was not even addressed in argument." }\end{array}$ & $\begin{array}{l}\mathrm{S} \text { o c i a } 1, \\
\text { conservative }\end{array}$ \\
\hline $\begin{array}{l}\text { A } \mathrm{d} \text { a } \mathrm{r} \text { a } \mathrm{n} \mathrm{d} \\
\text { Constructors, Inc., } \\
\text { v. Pena, } 515 \text { U.S. } \\
200 \text { (1995). }\end{array}$ & $\begin{array}{l}\text { Federal subcontractor incentives for minority enterprises } \\
\text { subject to strict scrutiny, remands. Dissent } 1 \text { (Stevens with } \\
\text { Ginsburg), defer to Congress. Dissent } 2 \text { (Souter with } \\
\text { Ginsburg and Breyer), political branches focus on affirmative } \\
\text { action. Dissent } 3 \text { (Ginsburg with Breyer), agreeable } \\
\text { precedent. }\end{array}$ & $\begin{array}{l}\mathrm{S} \text { o c i a } 1, \\
\text { conservative }\end{array}$ \\
\hline $\begin{array}{l}\text { Sandin v. Conner, } \\
515 \text { U.S. } 472 \\
(1995) \text {. }\end{array}$ & $\begin{array}{l}\text { Disciplinary solitary confinement did not trigger due process } \\
\text { interest. Dissent } 1 \text { (Ginsburg with Stevens), process } \\
\text { insufficient. Dissent } 2 \text { (Breyer with Souter), majority's } \\
\text { assumption of little hardship is wrong. }\end{array}$ & $\begin{array}{l}\mathrm{C} \text { r i m } 1 \text {, } \\
\text { conservative }\end{array}$ \\
\hline $\begin{array}{l}\text { Rosenberger v. } \\
\text { Rector \& Visitors } \\
\text { of The Univ. of } \\
\text { Va., } 515 \text { U.S. } 819 \\
\text { (1995). }\end{array}$ & $\begin{array}{l}\text { University cannot deny funding to religious student group. } \\
\text { Dissent (Souter with all), "The Court today, for the first time, } \\
\text { approves direct funding of core religious activities by an arm } \\
\text { of the State. It does so, however, only after erroneous } \\
\text { treatment of some familiar principles of law implementing the } \\
\text { First Amendment's Establishment and Speech Clauses, and } \\
\text { by viewing the very funds in question as beyond the reach of } \\
\text { the Establishment Clause's funding restrictions." }\end{array}$ & $\begin{array}{l}\mathrm{R} \text { e } 1 \text { i g i o } \mathrm{n} \text {, } \\
\text { conservative }\end{array}$ \\
\hline
\end{tabular}




\begin{tabular}{|c|c|c|}
\hline $\begin{array}{l}\text { Miller v. Johnson, } \\
515 \text { U.S. } 900 \\
(1995) \text {. }\end{array}$ & $\begin{array}{l}\text { Georgia's redistricting violates equal protection. Dissent } 1 \\
\text { (Stevens), no cognizable injury. Dissent } 2 \text { (Ginsburg with all), } \\
\text { "Applying this new 'race-as-predominant-factor' standard, the } \\
\text { Court invalidates Georgia's districting plan even though } \\
\text { Georgia's Eleventh District, the focus of today's dispute, bears } \\
\text { the imprint of familiar districting practices. Because I do not } \\
\text { endorse the Court's new standard and would not upset } \\
\text { Georgia's plan, I dissent." }\end{array}$ & $\begin{array}{l}\mathrm{V} \text { o } \mathrm{t} \text { i } \mathrm{n} \mathrm{g}, \\
\text { conservative }\end{array}$ \\
\hline $\begin{array}{l}\text { Netherland v. } \\
\text { Tuggle, } 515 \text { U.S. } \\
951 \text { (1995). }\end{array}$ & $\begin{array}{l}\text { Death habeas; per curiam: stay of execution granted by court } \\
\text { of appeals was not warranted if four justices would not vote } \\
\text { to grant cert and if no significant reversal possibility existed. } \\
\text { Dissent } 1 \text { (Stevens with Ginsburg), no abuse of discretion by } \\
\text { court of appeals, certiorari might be granted. Dissent } 2 \\
\text { (Souter), deny to vacate stay. Dissent } 3 \text { (Breyer, Stevens) } \\
\text { present. }\end{array}$ & $\begin{array}{l}\mathrm{C} \mathrm{r} \text { i m P r o, } \\
\text { conservative }\end{array}$ \\
\hline $\begin{array}{l}\text { W o o d } \quad \text { v. } \\
\text { Bartholomew, } 516 \\
\text { U.S. } 1 \text { (1995). }\end{array}$ & $\begin{array}{l}\text { Per curiam: Prosecutors need not disclose that witness had } \\
\text { failed polygraph test. Dissent from summary disposition, no } \\
\text { opinion. }\end{array}$ & $\begin{array}{l}\mathrm{C} \mathrm{r} \mathrm{i} \mathrm{m} \mathrm{P} \mathrm{r} \mathrm{o,} \\
\text { conservative }\end{array}$ \\
\hline $\begin{array}{l}\text { Seminole Tribe of } \\
\text { Fla. v. Fla., } 517 \\
\text { U.S. } 44 \text { (1996). }\end{array}$ & $\begin{array}{l}\text { State immune from tribe suit to force good faith negotiations } \\
\text { under gaming statute. Dissent } 1 \text { (Stevens), federal right must } \\
\text { have a remedy. Dissent } 2 \text { (Souter with all), "the Court today } \\
\text { holds for the first time since the founding of the Republic that } \\
\text { Congress has no authority to subject a State to the jurisdiction } \\
\text { of a federal court at the behest of an individual asserting a } \\
\text { federal right." }\end{array}$ & $\begin{array}{l}\mathrm{T} \mathrm{r} \text { i b a } 1, \\
\text { conservative }\end{array}$ \\
\hline $\begin{array}{l}\text { Shaw v. Hunt, } 517 \\
\text { U.S. } 899 \text { (1996). }\end{array}$ & $\begin{array}{l}\text { Overturns districting plan as not narrowly tailored to meet } \\
\text { needs. Dissent } 1 \text { (Stevens with Ginsburg \& Breyer), should } \\
\text { not apply strict scrutiny to majority-minority districts, even } \\
\text { so, this passes. Dissent } 2 \text { (Souter with Ginsburg and Breyer) } \\
\text { referring to dissent in Bush, } 116 \mathrm{~S} \text {. Ct. at } 1997 \text { (court needs to } \\
\text { give notice of standards), disagrees. }\end{array}$ & $\begin{array}{l}\mathrm{V} \text { o t i n } \mathrm{g}, \\
\text { conservative }\end{array}$ \\
\hline $\begin{array}{l}\text { Bush v. Vera, } 517 \\
\text { U.S. } 952 \text { (1996). }\end{array}$ & $\begin{array}{l}\text { Plurality increasing minority proportion of district violates } \\
\text { strict scrutiny. Dissent } 1 \text { (Stevens with Ginsburg and Breyer), } \\
\text { gerrymander is political, not racial, should return to law is in } \\
\text { Shaw v. Reno, } 509 \text { U.S. } 630,652 \text { (1993). Dissent } 2 \text { (Souter } \\
\text { with Ginsburg and Breyer), court should give notice of what } \\
\text { law is. }\end{array}$ & $\begin{array}{l}\mathrm{V} \text { o t i n g, } \\
\text { conservative }\end{array}$ \\
\hline $\begin{array}{l}\text { Koon v. United } \\
\text { States, } 518 \text { U.S. } 81 \\
(1996) .\end{array}$ & $\begin{array}{l}\text { Sentencing of police officers most downward departures valid } \\
\text { but not for loss of job. Dissent } 1 \text { (Stevens), may mitigate for } \\
\text { loss of job. Dissent } 2 \text { (Souter with Ginsburg), should not } \\
\text { mitigate for susceptibility to abuse in prison and for } \\
\text { successive prosecutions. Dissent } 3 \text { (Breyer with Ginsburg, } \\
\text { Souter), also no mitigation for successive prosecutions. Drop, } \\
\text { Stevens and Breyer would punish less, Souter \& Ginsburg } \\
\text { would punish more. }\end{array}$ & Dropped \\
\hline $\begin{array}{l}\text { Leavitt v. Jane L., } \\
518 \quad \text { U.S. } 137 \\
(1996) .\end{array}$ & $\begin{array}{l}\text { Per curiam. Abortion statute with constitutional and } \\
\text { unconstitutional parts; issue: were they severable? Majority: } \\
\text { yes (saving constitutional parts). Dissent (Stevens with all), } \\
\text { state law issue. }\end{array}$ & $\begin{array}{l}\text { A b o r t i o } \mathrm{n}, \\
\text { conservative }\end{array}$ \\
\hline
\end{tabular}




\begin{tabular}{|c|c|c|}
\hline $\begin{array}{l}\text { Gray v. Netherland, } \\
518 \text { U.S. } 152 \\
(1996) \text {. }\end{array}$ & $\begin{array}{l}\text { Death habeas; remands. Dissent } 1 \text { (Stevens), would reverse, } \\
\text { not even evidence to charge. Dissent } 2 \text { (Ginsburg with Souter, } \\
\text { Stevens, and Breyer), new unannounced evidence in } \\
\text { sentencing stage requires resentencing. }\end{array}$ & $\begin{array}{l}\mathrm{C} \text { r i m P r o, } \\
\text { conservative }\end{array}$ \\
\hline $\begin{array}{l}\text { Bd. of The County } \\
\text { Comm'rs of Bryan } \\
\text { County, Okla. v. } \\
\text { Brown, } 520 \text { U.S. } \\
397 \text { (1997). }\end{array}$ & $\begin{array}{l}\text { Excessive force in traffic stop } 1983 \text { claim vacated \& } \\
\text { remanded for not showing pattern. Dissent } 1 \text { (Souter with } \\
\text { Stevens and Breyer), single act liability possible. Dissent } 2 \\
\text { (Breyer with Stevens and Ginsburg), court makes liability far } \\
\text { too difficult. Topic administrative if about municipality } \\
\text { decisions, social if about policing. }\end{array}$ & $\begin{array}{l}\text { Admin./Social, } \\
\text { conservative }\end{array}$ \\
\hline $\begin{array}{l}\text { McMillian v. } \\
\text { Monroe County, } \\
\text { Ala., } 520 \text { U.S. } 781 \\
(1997) .\end{array}$ & $\begin{array}{l}\text { Death row exoneration } 1983 \text { claim v county fails for sheriff } \\
\text { represented state. Dissent (Ginsburg with all), sheriffs } \\
\text { represent counties given Alabama structure. }\end{array}$ & $\begin{array}{l}\mathrm{S} \text { o } \text { c i a } 1 \text {, } \\
\text { conservative }\end{array}$ \\
\hline $\begin{array}{l}\text { A b r a m s v. } \\
\text { Johnson, } 521 \text { U.S. } \\
74 \text { (1997). }\end{array}$ & $\begin{array}{l}\text { Upholds court districting plan producing one instead of three } \\
\text { majority-minority districts. Dissent (Breyer with all), Georgia } \\
\text { is } 27 \text { percent African-American, should have at least two of } \\
\text { its eleven districts be majority-minority. }\end{array}$ & $\begin{array}{l}\mathrm{V} \text { o t i n } \mathrm{g}, \\
\text { conservative }\end{array}$ \\
\hline $\begin{array}{l}\text { O'D e } 11 \quad \mathrm{v} . \\
\text { Netherland, } 521 \\
\text { U.S. } 151(1997)\end{array}$ & $\begin{array}{l}\text { not take retroactive advantage } \\
\text { tion about life without parole. } \\
\text { e is retroactive. }\end{array}$ & $\begin{array}{l}\mathrm{C} \mathrm{r} \text { i m P r o, } \\
\text { conservative }\end{array}$ \\
\hline $\begin{array}{l}\text { Agostini v. Felton, } \\
521 \quad \text { U.S. } 203 \\
(1997) \text {. }\end{array}$ & $\begin{array}{l}\text { School finance: Majority overrules precedent prohibiting } \\
\text { public school teachers to teach in parochial schools. Dissent } \\
1 \text { (Souter with all), no. Dissent } 2 \text { (Ginsburg with Breyer), } \\
\text { should not have heard the case. }\end{array}$ & $\begin{array}{l}\mathrm{S} \text { o c i a } 1 \text {, } \\
\text { conservative }\end{array}$ \\
\hline $\begin{array}{l}\text { Idaho, v. Coeur } \\
\text { d'Alene Tribe of } \\
\text { Idaho, } 521 \text { U.S. } \\
261 \text { (1997). }\end{array}$ & $\begin{array}{l}\text { Plurality: Eleventh Amendment bars tribe from claiming } \\
\text { compensation for submerged lands. Dissent (Souter with all), } \\
\text { falls within Ex parte Young, exercise federal right. } 209 \text { U.S. } \\
\text { 123, } 128 \text { (1908). }\end{array}$ & $\begin{array}{l}\mathrm{T} \text { r i b a } 1 \text {, } \\
\text { conservative }\end{array}$ \\
\hline $\begin{array}{l}\text { K a n s a s } \quad \mathrm{v} . \\
\text { Hendricks, } 521 \\
\text { U.S. } 346(1997)\end{array}$ & $\begin{array}{l}\text { Kansas sexual violent predator act civil commitment upheld } \\
\text { against vagueness and double jeopardy attacks. Dissent } \\
\text { (Breyer with Stevens and Souter, Ginsburg in part), it is } \\
\text { additional punishment and ex post facto. }\end{array}$ & $\begin{array}{l}\mathrm{C} \text { r i m l, } \\
\text { conservative }\end{array}$ \\
\hline $\begin{array}{l}\text { Printz v. United } \\
\text { States, } 521 \text { U.S. } \\
898 \text { (1997). }\end{array}$ & $\begin{array}{l}\text { Plurality invalidates parts of Brady Bill on background } \\
\text { checks in firearm sales. Dissent (Stevens with all), Congress } \\
\text { can impose enforcement obligations on local law enforcement } \\
\text { officers. }\end{array}$ & $\begin{array}{l}\text { Gun rights, } \\
\text { conservative }\end{array}$ \\
\hline $\begin{array}{l}\text { Calderon } \quad \mathrm{v} . \\
\text { Thompson, } 523 \\
\text { U.S. } 538(1998) \text {. }\end{array}$ & $\begin{array}{l}\text { Death habeas; Petitioner failed to show miscarriage of justice, } \\
\text { denied. Dissent (Souter with all), court's order should be } \\
\text { reviewed for abuse of discretion and courts have this } \\
\text { discretion normally (to change orders). }\end{array}$ & $\begin{array}{l}\mathrm{C} \text { r i m P r o, } \\
\text { conservative }\end{array}$ \\
\hline $\begin{array}{l}\text { Phillips v. Wash. } \\
\text { Legal Found., } 524 \\
\text { U.S. } 156 \text { (1998). }\end{array}$ & $\begin{array}{l}\text { Texas IOLTA is a taking. Dissent (Souter with all and Breyer } \\
\text { with all), no because no interest would be earned without } \\
\text { IOLTA. }\end{array}$ & $\begin{array}{l}\mathrm{S} \text { o c i a } 1 \text {, } \\
\text { conservative }\end{array}$ \\
\hline $\begin{array}{l}\text { Gebser v. Lago } \\
\text { Vista Indep. Sch. } \\
\text { Dist., } 524 \text { U.S. } 274 \\
\text { (1998). }\end{array}$ & $\begin{array}{l}\text { Implied private right of action under title IX versus teacher } \\
\text { requires actual notice to school and teacher. Dissent } 1 \\
\text { (Stevens with all), thwarts the purpose of title IX. Dissent } 2 \\
\text { (Ginsburg with Souter and Breyer), reporting mechanism } \\
\text { defense. }\end{array}$ & $\begin{array}{l}\mathrm{S} \text { o } \text { c i a } 1 \text {, } \\
\text { conservative }\end{array}$ \\
\hline
\end{tabular}




\begin{tabular}{|c|c|c|}
\hline $\begin{array}{l}\text { Pa. Bd. of Prob. \& } \\
\text { Parole v. Scott, } 524 \\
\text { U.S. } 357 \text { (1998). }\end{array}$ & $\begin{array}{l}\text { Parole boards need not suppress evidence that would have } \\
\text { been suppressed in trial. Dissent } 1 \text { (Stevens), remember that } \\
\text { the exclusionary rule is constitutionally required. Dissent } 2 \\
\text { (Souter with Ginsburg and Breyer), still need to deter Fourth } \\
\text { Amendment violations. }\end{array}$ & $\begin{array}{l}\text { C } \mathrm{r} \text { i } \mathrm{m} 1 \text {, } \\
\text { conservative }\end{array}$ \\
\hline $\begin{array}{l}\text { E. Enterprises v. } \\
\text { Apfel, } 524 \text { U.S. } \\
498 \text { (1998). }\end{array}$ & $\begin{array}{l}\text { Plurality: Coal Act's retroactive retirement funding obligation } \\
\text { on corp. that left the industry unconstitutional taking. Dissent } \\
1 \text { (Stevens with all), circuits being reversed were right, it was } \\
\text { lifetime health deal. Dissent } 2 \text { (Breyer with all), no taking, } \\
\text { reasonable regulation. }\end{array}$ & $\begin{array}{l}\text { Employment, } \\
\text { conservative }\end{array}$ \\
\hline $\begin{array}{l}\text { C a } 1 \text { d e r o n v. } \\
\text { Coleman, } 525 \text { U.S. } \\
141 \text { (1998). }\end{array}$ & $\begin{array}{l}\text { Death habeas; instruction fault could be harmless error. } \\
\text { Dissent (Stevens with all), lower courts sufficiently reasoned, } \\
\text { error not harmless, would deny cert. }\end{array}$ & $\begin{array}{l}\text { C r i m P r o } \\
\text { conservative }\end{array}$ \\
\hline $\begin{array}{l}\text { Grupo Mexicano } \\
\text { de Desarrollo, S.A., } \\
\text { v. All. Bond Fund, } \\
\text { Inc., } 527 \text { U.S. } 308 \\
\text { (1999). }\end{array}$ & $\begin{array}{l}\text { Preliminary injunction in favor of claimants against Mexican } \\
\text { toll road operator was premature. Dissent (Ginsburg with all), } \\
\text { claimants had satisfied all conditions for validity of } \\
\text { injunction. }\end{array}$ & $\begin{array}{l}\text { B u s in e s s, } \\
\text { conservative }\end{array}$ \\
\hline $\begin{array}{l}\text { Jones v. } \text { United } \\
\text { States, } 527 \text { U.S. } \\
373(1999) .\end{array}$ & $\begin{array}{l}\text { Death penalty. Plurality: jury did not need to be instructed on } \\
\text { consequences of not being unanimous. Dissent (Ginsburg } \\
\text { with Stevens and Souter, Breyer in part), would reverse and } \\
\text { remand for accurately informed jury. }\end{array}$ & $\begin{array}{l}\mathrm{C} \text { r i m P r o, } \\
\text { conservative }\end{array}$ \\
\hline $\begin{array}{l}\text { F1a. Prepaid } \\
\text { Postsecondary } \\
\text { Educ. Expense Bd. } \\
\text { v. Coll. Sav. Bank, } \\
527 \text { U.S. } 627 \\
(1999) \text {. }\end{array}$ & $\begin{array}{l}\text { Federal patent act cannot abrogate states' sovereign immunity. } \\
\text { Dissent (Stevens with all), act was appropriate exercise of } \\
\text { Congressional power. If about business, then liberal. }\end{array}$ & $\begin{array}{l}\text { F e d e r a } 1 \text { i s m, } \\
\text { conservative }\end{array}$ \\
\hline $\begin{array}{l}\text { Coll. Sav. Bank v. } \\
\text { F1a. Prepaid } \\
\text { Post s econdary } \\
\text { Educ. Expense Bd., } \\
527 \quad \text { U.S. } 666 \\
(1999) .\end{array}$ & $\begin{array}{l}\text { Trademark Remedy Clarification Act did not abrogate states' } \\
\text { sovereign immunity. Dissent } 1 \text { (Stevens), trade activities of } \\
\text { states should not be subject to sovereign immunity as foreign } \\
\text { sovereigns aren't. Dissent } 2 \text { (Breyer with all), against } \\
\text { precedent. If about business, then liberal. }\end{array}$ & $\begin{array}{l}\text { F e d e r a } 1 \text { is } \mathrm{m} \text {, } \\
\text { conservative }\end{array}$ \\
\hline $\begin{array}{l}\text { Alden v. Maine, } \\
527 \text { U.S. } 706 \\
(1999) .\end{array}$ & $\begin{array}{l}\text { Fair Labor Standards Act could not abrogate states' sovereign } \\
\text { immunity. Dissent (Souter with all), disagrees. }\end{array}$ & $\begin{array}{l}\text { Employment, } \\
\text { conservative }\end{array}$ \\
\hline $\begin{array}{l}\text { Kimel v. Fla. Bd. } \\
\text { of Regents, } 528 \\
\text { U.S. } 62(2000) \text {. }\end{array}$ & $\begin{array}{l}\text { Plurality: Age Discrimination In Employment Act did not } \\
\text { abrogate states' sovereign immunity. Dissent } 1 \text { (Stevens with } \\
\text { all), contra precedent. Concurrence (Thomas with Kennedy), } \\
\text { Congress did not make intent to abrogate Eleventh } \\
\text { Amendment immunity clear in statute. }\end{array}$ & $\begin{array}{l}\text { S o c i a } 1 \text {, } \\
\text { conservative }\end{array}$ \\
\hline $\begin{array}{l}\text { I } 11 \text { i n o i s } \quad \mathrm{v} \text {. } \\
\text { Wardlow, } 528 \text { U.S. } \\
119(2000) \text {. }\end{array}$ & $\begin{array}{l}\text { Search of person fleeing from converging police was } \\
\text { reasonable. Dissent (Stevens with all), no reasonable } \\
\text { suspicion for stop. }\end{array}$ & $\begin{array}{l}\text { C r i m P r o, } \\
\text { conservative }\end{array}$ \\
\hline $\begin{array}{l}\text { W e e k s v. } \\
\text { Angelone, } 528 \text { U.S. } \\
225(2000) \text {. }\end{array}$ & $\begin{array}{l}\text { Death habeas; jury instruction proper. Dissent (Stevens with } \\
\text { Ginsburg and Breyer, Souter in part), "virtual certainty" of } \\
\text { jury confusion. }\end{array}$ & $\begin{array}{l}\text { C r i m P r o, } \\
\text { conservative }\end{array}$ \\
\hline
\end{tabular}




\begin{tabular}{|c|c|c|}
\hline $\begin{array}{l}\text { Smith v. Robbins, } \\
528 \text { U.S. } 259 \\
(2000)\end{array}$ & $\begin{array}{l}\text { States can follow their own procedures to ensure adequate } \\
\text { representation, prejudice not presumed. Dissent } 1 \text { (Stevens } \\
\text { with Ginsburg), "sharp departure from settled law." Dissent } \\
2 \text { (Souter with all), state procedure is inadequate. }\end{array}$ & $\begin{array}{l}\mathrm{C} \text { r i m P r o, } \\
\text { conservative }\end{array}$ \\
\hline $\begin{array}{l}\text { Reno v. Bossier } \\
\text { Par. Sch. Bd., } 528 \\
\text { U.S. } 320 \text { (2000). }\end{array}$ & $\begin{array}{l}\text { Districting preclearance, plurality upholds nonretrogressive } \\
\text { but discriminatory plan. Dissent } 1 \text { (Stevens with Ginsburg), } \\
\text { Dept. of Justice's construction of statute deserves deference, } \\
\text { intent counts and plan fails. Dissent } 2 \text { (Breyer), retrogression } \\
\text { from zero impossible in } 1965 \text { so could not have been the } \\
\text { standard. Dissent } 3 \text { (Souter with all), precedent was against } \\
\text { text of act too. }\end{array}$ & $\begin{array}{l}\mathrm{V} \text { o t i n } \mathrm{g} \text {, } \\
\text { conservative }\end{array}$ \\
\hline $\begin{array}{l}\text { FDA v. Brown \& } \\
\text { W i } 11 \text { i a m s o n } \\
\text { Tobacco Corp., } 529 \\
\text { U.S. } 120 \text { (2000). }\end{array}$ & $\begin{array}{l}\text { FDA cannot regulate tobacco sales; dissent (By with all) } \\
\text { tobacco "affects structure of [a] function of the body" hence } \\
\text { subject to FDA. }\end{array}$ & $\begin{array}{l}\text { S o c i a } 1, \\
\text { conservative }\end{array}$ \\
\hline $\begin{array}{l}\text { Williams v. Taylor, } \\
529 \text { U.S. } 362 \\
(2000) \text {. }\end{array}$ & $\begin{array}{l}\text { Death habeas; overlapping complex pluralities with liberal } \\
\text { and conservative coalitions producing different components } \\
\text { of decision, dropped. }\end{array}$ & Dropped \\
\hline $\begin{array}{l}\text { United States v. } \\
\text { Morrison, } 529 \text { U.S. } \\
598(2000)\end{array}$ & $\begin{array}{l}\text { Civil remedies of Violence Against Women Act beyond } \\
\text { Congressional power; dissent } 1 \text { (Souter with all) Congress } \\
\text { showed effect in interstate commerce. Dissent } 2 \text { (Breyer with } \\
\text { all), resulting commerce clause law is unworkable. }\end{array}$ & $\begin{array}{l}\mathrm{S} \text { o c i a } 1, \\
\text { conservative }\end{array}$ \\
\hline $\begin{array}{l}\text { Ohler v. United } \\
\text { States, } 529 \text { U.S. } \\
753(2000) .\end{array}$ & $\begin{array}{l}\text { Defendant who preemptively introduces evidence of a prior } \\
\text { conviction on direct examination may not challenge the } \\
\text { admission of such evidence on appeal. Dissent (Souter with } \\
\text { all), "The holding is without support in precedent, the rules of } \\
\text { evidence, or the reasonable objectives of trial." }\end{array}$ & $\begin{array}{l}\mathrm{C} \text { r i m P r o, } \\
\text { conservative }\end{array}$ \\
\hline $\begin{array}{l}\text { R a m d a s s } \quad v . \\
\text { Angelone, } 530 \text { U.S. } \\
156(2000) \text {. }\end{array}$ & $\begin{array}{l}\text { Death habeas, denied } \mathrm{b} / \mathrm{c} \text { defendant was not entitled to } \\
\text { ineligibility instruction } \mathrm{b} / \mathrm{c} 3 \mathrm{rd} \text { prior conviction was not final; } \\
\text { dissent (Stevens with all), "acute unfairness in permitting a } \\
\text { State to rely on a recent conviction to establish a defendant's } \\
\text { future dangerousness while simultaneously permitting the } \\
\text { State to deny that there was such a conviction when the } \\
\text { defendant attempts to argue that he is parole ineligible and } \\
\text { therefore not a future danger." }\end{array}$ & $\begin{array}{l}\mathrm{C} \text { r i m P r o, } \\
\text { conservative }\end{array}$ \\
\hline $\begin{array}{l}\text { Carter v. United } \\
\text { States, } 530 \text { U.S. } \\
255(2000) .\end{array}$ & $\begin{array}{l}\text { Bank robber was not entitled to lesser included offense } \\
\text { instruction; dissent (Ginsburg with all), larceny is lesser- } \\
\text { included of robbery despite statutory niceties. }\end{array}$ & $\begin{array}{l}\mathrm{C} \text { r i m P r o, } \\
\text { conservative }\end{array}$ \\
\hline $\begin{array}{l}\text { Miller v. French, } \\
530 \text { U.S. } 327 \\
(2000) \text {. }\end{array}$ & $\begin{array}{l}\text { District Courts may not suspend auto stay of Prison Litigation } \\
\text { Reform Act; Dissent } 1 \text { (Souter with Ginsburg), "serious } \\
\text { separation-of-powers issue if the time it allows turns out to be } \\
\text { inadequate for a court to determine whether the new } \\
\text { prerequisite to relief is satisfied." Dissent } 2 \text { (Breyer with } \\
\text { Stevens), not what the statute says, District Court may } \\
\text { reinstate injunction. }\end{array}$ & $\begin{array}{l}\text { C } \mathrm{r} \text { i } \mathrm{m} \quad 1 \text {, } \\
\text { conservative }\end{array}$ \\
\hline
\end{tabular}




\begin{tabular}{|c|c|c|}
\hline $\begin{array}{l}\text { Boy Scouts of Am. } \\
\text { v. Dale, } 530 \text { U.S. } \\
640(2000) \text {. }\end{array}$ & $\begin{array}{l}\text { New Jersey law requiring Boy Scouts to readmit gay person } \\
\text { violated their First Amendment rights. Dissent } 1 \text { (Stevens } \\
\text { with all), no impediment of BSA, no First Amendment } \\
\text { violation. Dissent } 2 \text { (Souter with Ginsburg and Breyer), "I } \\
\text { conclude that BSA has not made out an expressive } \\
\text { association claim, therefore, not because of what BSA may } \\
\text { espouse, but because of its failure to make sexual orientation } \\
\text { the subject of any unequivocal advocacy, using the channels } \\
\text { it customarily employs to state its message." }\end{array}$ & $\begin{array}{l}\mathrm{S} \text { o c i a } 1 \\
\text { conservative }\end{array}$ \\
\hline $\begin{array}{l}\text { Green Tree Fin. } \\
\text { Corp. - Ala. v. } \\
\text { Randolph, } 531 \text { U.S. } \\
79 \text { (2000). }\end{array}$ & $\begin{array}{l}\text { Mobile home financing arbitration upheld. Dissent (Ginsburg } \\
\text { with all), costs of access to arbitration unknown, case unripe } \\
\text { for decision. }\end{array}$ & $\begin{array}{l}\text { B u s i n e s s, } \\
\text { conservative }\end{array}$ \\
\hline $\begin{array}{l}\text { Bush v. Gore, } 531 \\
\text { U.S. } 98 \text { (2000). }\end{array}$ & $\begin{array}{l}\text { Per curiam: Florida order inappropriate. Four dissents: should } \\
\text { have allowed recount to conclude. }\end{array}$ & $\begin{array}{l}\text { S o c i a } 1 \text {, } \\
\text { conservative }\end{array}$ \\
\hline $\begin{array}{l}\text { Solid W a ste } \\
\text { Agency of N. Cook } \\
\text { County v. United } \\
\text { States Army Corps } \\
\text { of Eng'rs, } 531 \text { U.S. } \\
159 \text { (2001). }\end{array}$ & $\begin{array}{l}\text { Army Corps of Engineers using Clean Water Act to obtain } \\
\text { jurisdiction over non-navigable waters inappropriate. Dissent } \\
\text { (Stevens with all), statute does not require navigability. }\end{array}$ & $\begin{array}{l}\text { S o c i a } 1 \\
\text { conservative }\end{array}$ \\
\hline $\begin{array}{l}\text { Bd. of Tr. of The } \\
\text { Univ. of Ala. v. } \\
\text { Patricia Garrett, } \\
531 \text { U.S. } 356 \\
(2001) \text {. }\end{array}$ & $\begin{array}{l}\text { Americans with Disabilities Act did not abrogate states' } \\
\text { Eleventh Amendment immunity. Dissent (Breyer with all), } \\
\text { Congress may enforce equal protection guarantee of } \\
\text { Fourteenth Amendment as it pleases, it is not an agency. }\end{array}$ & $\begin{array}{l}\text { S o c i a } 1 \text {, } \\
\text { conservative }\end{array}$ \\
\hline $\begin{array}{l}\text { Circuit City Stores, } \\
\text { Inc., v. Adams, } 532 \\
\text { U.S. } 105 \text { (2001). }\end{array}$ & $\begin{array}{l}\text { Federal Arbitration Act applies to employment contract only } \\
\text { in interstate commerce. Dissent } 1 \text { (Stevens with all), FAA } \\
\text { was not supposed to apply to employment contracts by its } \\
\text { text. Dissent } 2 \text { (Souter with all), Congress wrote general } \\
\text { exclusion of employment contracts. }\end{array}$ & $\begin{array}{l}\text { Employment, } \\
\text { conservative }\end{array}$ \\
\hline $\begin{array}{l}\text { Tex. v. Cobb, } 532 \\
\text { U.S. } 162(2001) \text {. }\end{array}$ & $\begin{array}{l}\text { Death penalty; plurality: right to counsel only exists for } \\
\text { charged offenses. Dissent (Breyer with all), "unnecessarily } \\
\text { technical definition undermines Sixth Amendment } \\
\text { protections while doing nothing to further effective law } \\
\text { enforcement." }\end{array}$ & $\begin{array}{l}\text { C r i m P r o, } \\
\text { conservative }\end{array}$ \\
\hline $\begin{array}{l}\text { Alex ander v. } \\
\text { Sandoval, } 532 \text { U.S. } \\
275 \text { (2001). }\end{array}$ & $\begin{array}{l}\text { No private right of action to enforce disparate-impact } \\
\text { regulations, hence no Spanish test for driver's license. Dissent } \\
\text { (Stevens with all), at the time of passage, rule was private rt } \\
\text { of action was implied unless excluded. }\end{array}$ & $\begin{array}{l}\text { S o c i a } 1 \\
\text { conservative }\end{array}$ \\
\hline $\begin{array}{l}\text { Daniels v. United } \\
\text { States, } 532 \text { U.S. } \\
374 \text { (2001). }\end{array}$ & $\begin{array}{l}\text { Defendant cannot collaterally attack prior conviction used for } \\
\text { three strikes. Dissent } 1 \text { (Souter with Stevens \& Ginsburg), } \\
\text { "Why should it be easy to subject a person to a higher } \\
\text { sentencing range and commit him for nearly nine extra years } \\
\text { (as here) when the prisoner has a colorable claim that the } \\
\text { extended commitment rests on a conviction the Constitution } \\
\text { would condemn?" Dissent } 2 \text { (Breyer), "the Court's earlier } \\
\text { decision will lead to ever-increasing complexity, for it blocks } \\
\text { the simpler procedural approach that Congress intended." }\end{array}$ & $\begin{array}{l}\text { C r i m P r o, } \\
\text { conservative }\end{array}$ \\
\hline
\end{tabular}




\begin{tabular}{|c|c|c|}
\hline $\begin{array}{l}\text { L a c k a w a n a } \\
\text { County Dist. } \\
\text { Attorney v. Coss, } \\
532 \text { U.S. } \quad 394 \\
(2001) \text {. }\end{array}$ & $\begin{array}{l}\text { Prior enhancement sentence did not influence current penalty. } \\
\text { Dissent } 1 \text { (Souter with Ginsburg \& Stevens), it did in several } \\
\text { ways, also dissent in Daniel (immediately above). Dissent } 2 \\
\text { (Breyer), issue not briefed, remand to consider. }\end{array}$ & $\begin{array}{l}\text { C r i m P r o, } \\
\text { conservative }\end{array}$ \\
\hline $\begin{array}{l}\text { Buckhannon Bd. \& } \\
\text { Care Home, Inc., v. } \\
\text { W. Va. Dep't of } \\
\text { Health \& Human } \\
\text { Res., } 532 \text { U.S. } 598 \\
\text { (2001). }\end{array}$ & $\begin{array}{l}\text { Fee-shifting of Fair housing and ADA need decision on the } \\
\text { merits. Dissent (Ginsburg with all), "upsets long-prevailing } \\
\text { Circuit precedent applicable to scores of federal fee-shifting } \\
\text { statutes." }\end{array}$ & $\begin{array}{l}\text { B u s i n e s s, } \\
\text { conservative }\end{array}$ \\
\hline $\begin{array}{l}\text { NLRB v. Ky. River } \\
\text { Cmty. Care, Inc., } \\
532 \text { U.S. } 706 \\
(2001) \text {. }\end{array}$ & $\begin{array}{l}\text { Nurses are supervisors, no right to unionize. Dissent (Stevens } \\
\text { with all), they are not supervisors. }\end{array}$ & $\begin{array}{l}\text { Employment, } \\
\text { conservative }\end{array}$ \\
\hline $\begin{array}{l}\text { Lorillard Tobacco } \\
\text { Co. v. Reilly, } 533 \\
\text { U.S. } 525 \text { (2001). }\end{array}$ & $\begin{array}{l}\text { Cigarette sale regulating statute of Massachusetts challenged } \\
\text { on preemption and First Amendment grounds; plurality: } \\
\text { advertising ban preempted, ads within 1,000 feet of schools } \\
\text { cannot be barred on First Amendment grounds. Dissent } 1 \\
\text { (Souter), remand on 1,000 feet from school issue. Dissent } 2 \\
\text { (Stevens with all), federal statute does not preempt, would } \\
\text { also vacate on First Amendment and remand for trial. }\end{array}$ & $\begin{array}{l}\text { B u s i n e s s, } \\
\text { conservative }\end{array}$ \\
\hline $\begin{array}{l}\text { Palazzolo v. } \text { R.I., } \\
533 \text { U.S. } 606 \\
(2001) .\end{array}$ & $\begin{array}{l}\text { Plurality: regulatory taking remand. Dissent } 1 \text { (Stevens), } \\
\text { regulation can be challenged. Dissent } 2 \text { (Ginsburg with } \\
\text { Stevens \& Breyer), owner could develop uplands only. } \\
\text { Dissent } 3 \text { (Breyer), must not create incentive to transfer non- } \\
\text { regulated part of land in order to manufacture takings claim. }\end{array}$ & $\begin{array}{l}\mathrm{T} \text { a } \mathrm{k} \text { i n } \mathrm{g} \mathrm{s}, \\
\text { conservative }\end{array}$ \\
\hline $\begin{array}{l}\text { Tyler v. Cain, } 533 \\
\text { U.S. } 656(2001) .\end{array}$ & $\begin{array}{l}\text { Opinion on jury instruction defect about reasonable doubt is } \\
\text { not retroactive, habeas fails. Dissent believes it is retroactive. }\end{array}$ & $\begin{array}{l}\text { C r i m P r o, } \\
\text { conservative }\end{array}$ \\
\hline $\begin{array}{l}\text { Corr. Servs. Corp. } \\
\text { v. Malesko, } 534 \\
\text { U.S. } 61(2001) .\end{array}$ & $\begin{array}{l}\text { No Bivens private right of action against private entities, and } \\
\text { heart attack claim of prisoner fails. Dissent (Stevens), against } \\
\text { natural flow of precedent. }\end{array}$ & $\begin{array}{l}\text { Admin/Business, } \\
\text { conservative }\end{array}$ \\
\hline $\begin{array}{l}\text { Dusenbery } \mathrm{v} . \\
\text { United States, } 534 \\
\text { U.S. } 161(2002) \text {. }\end{array}$ & $\begin{array}{l}\text { Notice of forfeiture to prison and mom was proper. Dissent } \\
\text { (Ginsburg), due process demands right to be heard. }\end{array}$ & $\begin{array}{l}\text { C r i m P r o, } \\
\text { conservative }\end{array}$ \\
\hline $\begin{array}{l}\text { Great-W. Life \& } \\
\text { Annuity Ins. Co. v. } \\
\text { Knudson, } 534 \text { U.S. } \\
204(2002) .\end{array}$ & $\begin{array}{l}\text { Under ERISA and common law, health insurer limited to } \\
\text { recover from insured actual recovery, not attorney's fees or } \\
\text { amount in trust. Dissent } 1 \text { (Stevens), ERISA provision was } \\
\text { intended to increase judges' latitude; dissent } 2 \text { (Ginsburg with } \\
\text { all), "treat[s] as dispositive an ancient classification unrelated } \\
\text { to the substance of the relief sought; and . . obstruct[s] the } \\
\text { general goals of ERISA by relegating to state court (or to no } \\
\text { court at all) an array of suits involving the interpretation of } \\
\text { employee health plan provisions." }\end{array}$ & $\begin{array}{l}\mathrm{H} \text { e a } 1 \mathrm{t} \mathrm{h}, \\
\text { conservative }\end{array}$ \\
\hline $\begin{array}{l}\text { Hoffman Plastic } \\
\text { Compounds, Inc., } \\
\text { v. NLRB, } 535 \text { U.S. } \\
137 \text { (2002). }\end{array}$ & $\begin{array}{l}\text { NLRB cannot award backpay to undocumented alien. Dissent } \\
\text { (Breyer with all), deter illegal activity. }\end{array}$ & $\begin{array}{l}\text { Employment, } \\
\text { conservative }\end{array}$ \\
\hline
\end{tabular}




\begin{tabular}{|c|c|c|}
\hline $\begin{array}{l}\text { Mickens v. Taylor, } \\
535 \quad \text { U.S. } 162 \\
(2002) \text {. }\end{array}$ & $\begin{array}{l}\text { Prisoner was sentenced to death and filed a writ for habeas } \\
\text { corpus, claiming his attorney had a conflict of interest that } \\
\text { court knew had to have influenced outcome to be grounds. } \\
\text { Dissent } 1 \text { (Stevens), likely prejudicial. Dissent } 2 \text { (Souter), } \\
\text { judge must inquire about conflict and replace counsel. } \\
\text { Dissent } 3 \text { (Breyer with Ginsburg), automatic reversal. }\end{array}$ & $\begin{array}{l}\mathrm{C} \text { r i m P r o, } \\
\text { conservative }\end{array}$ \\
\hline $\begin{array}{l}\text { City of L.A. v. } \\
\text { Alameda Books, } \\
535 \text { U.S. } 425 \\
(2002)\end{array}$ & $\begin{array}{l}\text { Restriction of a second obscene bookstore in building } \\
\text { ordinance was challenged. Plurality: city could reasonably } \\
\text { rely on police department study correlating crime patterns } \\
\text { with concentrations of adult business. Dissent (Souter with } \\
\text { all), prohibiting same establishment from various businesses } \\
\text { (books and DVDs) by requiring two rents and other costs } \\
\text { drives it out of business and functions as content regulation. }\end{array}$ & $\begin{array}{l}\mathrm{S} \text { o c i a } 1, \\
\text { conservative }\end{array}$ \\
\hline $\begin{array}{l}\text { FMC v. S.C. State } \\
\text { Ports Auth., } 535 \\
\text { U.S. } 743 \text { (2002). }\end{array}$ & $\begin{array}{l}\text { Sovereign immunity bars FMC from adjudicating claim } \\
\text { versus state-run port. Dissent } 1 \text { (Stevens), rationale } \\
\text { "embarrassing insufficient." Dissent } 2 \text { (Breyer with all), } \\
\text { against precedent and Constitution. }\end{array}$ & $\begin{array}{l}\text { A } \mathrm{d} \text { m } \mathrm{i} n \text {, } \\
\text { conservative }\end{array}$ \\
\hline $\begin{array}{l}\text { McKune v. Lile, } \\
\text { 536 U.S. } 24 \text { (2002). }\end{array}$ & $\begin{array}{l}\text { Prisoner brought } 42 \text { USC } \$ 1983 \text { suit against prison officials } \\
\text { for violation of right not to self-incriminate. Majority held } \\
\text { consequences from not participating in sex abuser treatment } \\
\text { not so severe as to force self-incrimination. Dissent (Stevens } \\
\text { with all), "[n]or have we ever held that a person who has } \\
\text { made a valid assertion of the privilege may nevertheless be } \\
\text { ordered to incriminate himself and sanctioned for disobeying } \\
\text { such an order. This is truly a watershed case." }\end{array}$ & $\begin{array}{l}\mathrm{C} \mathrm{r} \mathrm{i} \mathrm{m} 1 \text {, } \\
\text { conservative }\end{array}$ \\
\hline $\begin{array}{l}Z \text { e } 1 \mathrm{~m} \text { a } \mathrm{n} \\
\text { Simmons-Harris, } \\
536 \text { U.S. } 639 \\
(2002) .\end{array}$ & $\begin{array}{l}\text { School voucher program did not violate establishment clause. } \\
\text { Dissent } 1 \text { (Stevens), the use of public funds is indoctrination. } \\
\text { Dissent } 2 \text { (Souter with all) failure of public schools does not } \\
\text { excuse establishment. Dissent } 3 \text { (Breyer with Stevens and } \\
\text { Souter), socially explosive; parental choice is not a remedy. }\end{array}$ & $\begin{array}{l}\mathrm{S} \text { o c i a } 1, \\
\text { conservative }\end{array}$ \\
\hline $\begin{array}{l}\text { Republican Party v. } \\
\text { White, } 536 \text { U.S. } \\
765 \text { (2002). }\end{array}$ & $\begin{array}{l}\text { Prohibition on candidates for judicial elections from } \\
\text { announcing positions violates First Amendment. Dissent } 1 \\
\text { (Stevens with all), judges are not supposed to be popular. } \\
\text { Dissent } 2 \text { (Ginsburg with all), by having elected judges, } \\
\text { Minnesota "has not thereby opted to install a corps of political } \\
\text { actors on the bench," "would differentiate elections for } \\
\text { political offices, in which the First Amendment holds full } \\
\text { sway, from elections designed to select those whose office it } \\
\text { is to administer justice without respect to persons. } \\
\text { Minnesota's choice to elect its judges, I am persuaded, does } \\
\text { not preclude the State from installing an election process } \\
\text { geared to the judicial office." }\end{array}$ & $\begin{array}{l}\mathrm{S} p \text { e e c h, } \\
\text { conservative }\end{array}$ \\
\hline $\begin{array}{l}\text { Sattazahn v. Pa., } \\
537 \text { U.S. } 101 \\
(2003) .\end{array}$ & $\begin{array}{l}\text { Death penalty; death after successful appeal of life sentence } \\
\text { does not violate double jeopardy due to deadlock of first jury. } \\
\text { Dissent (Ginsburg with all), a final judgment is a jeopardy- } \\
\text { determinative event. }\end{array}$ & $\begin{array}{l}\mathrm{C} \text { r i m P r o, } \\
\text { conservative }\end{array}$ \\
\hline
\end{tabular}




\begin{tabular}{|c|c|c|}
\hline $\begin{array}{l}\text { Ewing v. Cal., } 538 \\
\text { U.S. } 11 \text { (2003). }\end{array}$ & $\begin{array}{l}\text { Twenty-five-year sentence after three strikes for felony grand } \\
\text { theft was not cruel and unusual. Dissent } 1 \text { (Stevens with all), } \\
\text { Breyer's proportionality required by Constitution. Dissent } 2 \\
\text { (Breyer with all), precedent standard is grossly } \\
\text { disproportionate, and making this disproportionate. }\end{array}$ & $\begin{array}{l}\text { C } \mathrm{r} \text { i } \mathrm{m} 1 \text {, } \\
\text { conservative }\end{array}$ \\
\hline $\begin{array}{l}\text { L o c k y e r } \quad \mathrm{v} \text {. } \\
\text { Andrade, } 538 \text { U.S. } \\
63 \text { (2003). }\end{array}$ & $\begin{array}{l}\text { Life sentence for two petty thefts per California three-strikes } \\
\text { statute valid. Dissent (Souter with all), same reasons as in } \\
\text { Justice Breyer's dissent in Ewing, } 538 \text { U.S. } 11 \text {. }\end{array}$ & $\begin{array}{l}\text { C } \mathrm{r} \text { i } \mathrm{m} 1 \text {, } \\
\text { conservative }\end{array}$ \\
\hline $\begin{array}{l}\text { Demore v. Kim, } \\
538 \text { U.S. } 510 \\
(2003) \text {. }\end{array}$ & $\begin{array}{l}\text { Plurality: No-bail provision of Immigration and } \\
\text { Naturalization Act valid. Dissent } 1 \text { (Souter with Stevens \& } \\
\text { Ginsburg), "The Court's holding that the Constitution permits } \\
\text { the Government to lock up a lawful permanent resident of this } \\
\text { country when there is concededly no reason to do so forgets } \\
\text { over a century of precedent . . ." Dissent } 2 \text { (Breyer), } \\
\text { defendant's claims that he is not deportable are strong enough } \\
\text { that he should get bail. }\end{array}$ & $\begin{array}{l}\mathrm{C} \text { r i m P r o, } \\
\text { conservative }\end{array}$ \\
\hline $\begin{array}{l}\text { Ga. v. Ashcroft, } \\
539 \text { U.S. } 461 \\
(2003) \text {. }\end{array}$ & $\begin{array}{l}\text { Challenge to refusal of preclearance to Georgia's districting, } \\
\text { plurality remand favorable to Georgia. Dissent (Souter with } \\
\text { all), switch from majority-minority districts to coalition } \\
\text { districts possible, but state bears burden that others will form } \\
\text { coalition with minority. }\end{array}$ & $\begin{array}{l}\mathrm{V} \text { o } \mathrm{t} \text { i n } \mathrm{g}, \\
\text { conservative }\end{array}$ \\
\hline $\begin{array}{l}\text { Vieth v. Jubelirer, } \\
541 \text { U.S. } 267 \\
(2004) \text {. }\end{array}$ & $\begin{array}{l}\text { Plurality: political gerrymandering is nonjusticiable. Dissent } \\
1 \text { (Stevens), plurality "would give license, for the first time, } \\
\text { to partisan gerrymanders that are devoid of any rational } \\
\text { justification." Dissent } 2 \text { (Souter with Ginsburg), court need } \\
\text { not abandon effort to define prohibited political } \\
\text { gerrymandering. Dissent } 3 \text { (Breyer), would remand for } \\
\text { plaintiffs to show harm from political gerrymandering. }\end{array}$ & $\begin{array}{l}\mathrm{V} \text { o t i n g, } \\
\text { conservative }\end{array}$ \\
\hline $\begin{array}{l}\text { Grupo Dataflux v. } \\
\text { Atlas Glob. Grp. } \\
\text { L.P., } 541 \text { U.S. } 567 \\
(2004) \text {. }\end{array}$ & $\begin{array}{l}\text { Cannot cure lack of diversity jurisdiction by change after } \\
\text { filing. Dissent (Ginsburg with all), defect had been cured } \\
\text { before trial and is not fatal. }\end{array}$ & $\begin{array}{l}\text { A } \mathrm{d} \mathrm{m} \mathrm{i} \mathrm{n} . \\
\text { conservative }\end{array}$ \\
\hline $\begin{array}{l}\text { Yarborough v. } \\
\text { Alvarado, } 541 \text { U.S. } \\
652(2004) \text {. }\end{array}$ & $\begin{array}{l}\text { Plurality declines to suppress } 17 \text {-year-old's confession } \\
\text { without Miranda warnings because he was not in custody. } \\
\text { Dissent (Breyer with all), he was in custody. }\end{array}$ & $\begin{array}{l}\mathrm{C} \mathrm{ri} \mathrm{m} \mathrm{P} \mathrm{r} \mathrm{o,} \\
\text { conservative }\end{array}$ \\
\hline $\begin{array}{l}\text { Hiibel v. Sixth } \\
\text { Judicial Dist. Ct., } \\
542 \quad \text { U.S. } 177 \\
(2004) \text {. }\end{array}$ & $\begin{array}{l}\text { Arrest for violating statute requiring one to identify oneself } \\
\text { was proper. Dissent } 1 \text { (Stevens), violates right against self- } \\
\text { incrimination. Dissent } 2 \text { (Breyer with Souter \& Ginsburg), } \\
\text { contrary to consistent strong dicta. }\end{array}$ & $\begin{array}{l}\text { C } \mathrm{r} \text { i } \mathrm{m} 1 \text {, } \\
\text { conservative }\end{array}$ \\
\hline $\begin{array}{l}\text { S c h r i r o } \\
\text { Summerlin, } 542 \\
\text { U.S. } 348 \text { (2004). }\end{array}$ & $\begin{array}{l}\text { Death habeas; interpretation requiring jury to find aggravators } \\
\text { was not retroactive. Dissent (Breyer with all), fits criteria for } \\
\text { retroactivity. }\end{array}$ & $\begin{array}{l}\mathrm{C} \mathrm{ri} \mathrm{m} \mathrm{P} \mathrm{r} \mathrm{o,} \\
\text { conservative }\end{array}$ \\
\hline $\begin{array}{l}\text { Beard v. Banks, } \\
542 \text { U.S. } 406 \\
(2004) \text {. }\end{array}$ & $\begin{array}{l}\text { Death habeas; rule of Mills was not retroactive. Dissent } 1 \\
\text { (Stevens with all), wanton imposition of death penalty. } \\
\text { Dissent } 2 \text { (Souter with Ginsburg), need more accuracy in } \\
\text { death penalties. }\end{array}$ & $\begin{array}{l}\mathrm{C} \mathrm{r} \mathrm{i} \mathrm{m} \mathrm{P} \mathrm{r} \mathrm{o,} \\
\text { conservative }\end{array}$ \\
\hline $\begin{array}{l}\text { Ru m s fe } 1 \mathrm{~d} \quad \mathrm{v} . \\
\text { Padilla, } 542 \text { U.S. } \\
426(2004)\end{array}$ & $\begin{array}{l}\text { Plurality: SDNY has no jurisdiction over enemy combatant } \\
\text { U.S. citizen held in South Carolina. Dissent (Stevens with } \\
\text { all), important case over which the court clearly has } \\
\text { jurisdiction and must decide. }\end{array}$ & $\begin{array}{l}\mathrm{C} \mathrm{r} \text { i m } \mathrm{P} \mathrm{r} \text { o, } \\
\text { conservative }\end{array}$ \\
\hline
\end{tabular}




\begin{tabular}{|c|c|c|}
\hline $\begin{array}{l}\text { United States v. } \\
\text { Patane, } 542 \text { U.S. } \\
630(2004)\end{array}$ & $\begin{array}{l}\text { Plurality: Lack of Miranda warnings does not suppress found } \\
\text { firearms and voluntary statements. Dissent } 1 \text { (Souter with } \\
\text { Stevens \& Ginsburg), inducement to ignore Miranda. Dissent } \\
2 \text { (Breyer), should follow Seibert and suppress. }\end{array}$ & $\begin{array}{l}\mathrm{C} \text { r i m P r o, } \\
\text { conservative }\end{array}$ \\
\hline $\begin{array}{l}\text { Holland v. Jackson, } \\
542 \text { U.S. } 649 \\
(2004) \text {. }\end{array}$ & $\begin{array}{l}\text { Non-capital murder habeas; per curiam; claim of ineffective } \\
\text { assistance properly defeated as not prejudicial. Dissent would } \\
\text { deny certiorari (and uphold grant of habeas by court of } \\
\text { appeals). }\end{array}$ & $\begin{array}{l}\mathrm{C} \text { r i m P r o, } \\
\text { conservative }\end{array}$ \\
\hline $\begin{array}{l}\text { Jama v. Immigr. \& } \\
\text { Customs Enf't, } 543 \\
\text { U.S. } 335 \text { (2005). }\end{array}$ & $\begin{array}{l}\text { Removal of alien to country of birth proper even if it will not } \\
\text { be hospitable. Dissent (Souter with all), the statutory text } \\
\text { requires country to accept him. }\end{array}$ & $\begin{array}{l}\text { A } \mathrm{d} \mathrm{m} \mathrm{i} \mathrm{n} \text {, } \\
\text { conservative }\end{array}$ \\
\hline $\begin{array}{l}\text { P a c e } \quad v . \\
\text { DiGuglielmo, } 544 \\
\text { U.S. } 408(2005)\end{array}$ & $\begin{array}{l}\text { Murder habeas; limitation was not tolled, petition is untimely. } \\
\text { Dissent (Stevens with all), "The Court's interpretation of } \S \\
2244(d)(2) \text { is not compelled by the text of that provision and } \\
\text { will most assuredly frustrate its purpose." }\end{array}$ & $\begin{array}{l}\mathrm{C} \text { r i m P r o, } \\
\text { conservative }\end{array}$ \\
\hline $\begin{array}{l}\text { Dodd v. U.S., } 545 \\
\text { U.S. } 353 \text { (2005). }\end{array}$ & $\begin{array}{l}\text { Rule that jury had to be unanimous in all aggravators was } \\
\text { more than a year old at filing of petition, therefore petition } \\
\text { was untimely. Dissent } 1 \text { (Stevens with all), cannot have } \\
\text { "limitations period to expire before the cause of action } \\
\text { accrues." Dissent } 2 \text { (Ginsburg with Breyer), "exalts form over } \\
\text { reality." }\end{array}$ & $\begin{array}{l}\mathrm{C} \text { r i m P r o, } \\
\text { conservative }\end{array}$ \\
\hline $\begin{array}{l}\text { Bell v. Thompson, } \\
545 \text { U.S. } 794 \\
(2005) \text {. }\end{array}$ & $\begin{array}{l}\text { Death habeas; court of appeals did not have sufficient } \\
\text { grounds in ineffective assistance claims to reverse. Dissent } \\
\text { (Breyer with all), extraordinary circumstances, no abuse of } \\
\text { discretion. }\end{array}$ & $\begin{array}{l}\mathrm{C} \text { r i m P r o, } \\
\text { conservative }\end{array}$ \\
\hline
\end{tabular}

6. REHNQUIST-KENNEDY-SCALIA-STEVENS-THOMAS (FOUR O'CLOCK)

\begin{tabular}{|l|l|l|}
\hline $\begin{array}{l}\text { U.S. v. Lopez, 514 } \\
\text { U.S. 549 (1995). }\end{array}$ & $\begin{array}{l}\text { Plurality: Gun-free zones exceed commerce power. Dissent } \\
1 \text { (Stevens), no, commerce depends on education. Dissent 2 } \\
\text { (Souter), meets rational basis, which is the test. Dissent 3 } \\
\text { (Breyer with all), meets traditional commerce clause test. }\end{array}$ & $\begin{array}{l}\text { G u n rights, } \\
\text { conservative }\end{array}$ \\
\hline $\begin{array}{l}\text { Mo. v. Jenkins, 515 } \\
\text { U.S. 70 (1995). }\end{array}$ & $\begin{array}{l}\text { Invalidating orders of district court attempting to desegregate } \\
\text { Missouri schools. Dissent (Souter with all), "overrule[s] a } \\
\text { unanimous constitutional precedent of 20 years standing, } \\
\text { which was not even addressed in argument..." }\end{array}$ & $\begin{array}{l}\text { S conservative } \\
\text { A d a r a n d }\end{array}$ \\
\hline $\begin{array}{l}\text { Federal subcontractor incentives for minority enterprises are } \\
\text { Penstructors, v. } 515 \text { U.S. 200 } \\
\text { (1995). }\end{array}$ & $\begin{array}{l}\text { Ginject to strict scrutiny, remands. Dissent 1 (Stevens with } \\
\text { \& Ginsburg), political branches focus on affirmative action. }\end{array}$ & conservative \\
\hline
\end{tabular}

\section{REHNQUIST-KENNEDY-SCALIA-SOUTER-THOMAS (FIVE O'CLOCK)}

\begin{tabular}{|l|l|l|}
\hline $\begin{array}{l}\text { L a m b rix v. } \\
\text { Singletary, 520 } \\
\text { U.S. 518 (1997). }\end{array}$ & $\begin{array}{l}\text { Heinous-Atrocious-Cruel instruction was given to jury, but } \\
\text { was not further defined, requires retrial. Dissent finds that the } \\
\text { Florida Supreme Court appropriately considered it waived. }\end{array}$ & CrimPro, liberal \\
\hline $\begin{array}{l}\text { Atwater v. City of } \\
\text { Lago Vista, 532 } \\
\text { U.S. } 318 \text { (2001). }\end{array}$ & $\begin{array}{l}\text { Arrest for trivial violation (not wearing seatbelt) is proper. } \\
\text { Dissent would consider it violating the Fourth Amendment. }\end{array}$ & $\begin{array}{l}\text { C r i m P r o , } \\
\text { conservative }\end{array}$ \\
\hline
\end{tabular}




\begin{tabular}{|l|l|l|}
\hline Exxon Mobil Corp. & Supplemental plaintiffs need not meet amount in controversy & CivPro, liberal \\
v. Allapattah Servs, & (interpretation of Civil Procedure statute). Dissent would not & \\
Inc., 545 U.S. 546 & allow them to join. & \\
$(2005)$. & & \\
\hline
\end{tabular}

\section{BREYER-GINSBURG-SOUTER-STEVENS-THOMAS (EIGHT O'CLOCK)}

\begin{tabular}{|l|l|l|}
\hline $\begin{array}{l}\text { United States v. } \\
\text { Bajakajian, 524 } \\
\text { U.S. 321 (1998). }\end{array}$ & $\begin{array}{l}\text { Civil forfeiture of entire \$357k undeclared at airport } \\
\text { excessive, violating Eighth Amendment. Dissent would } \\
\text { uphold. }\end{array}$ & Admin, liberal \\
\hline $\begin{array}{l}\text { A M T R A K v. } \\
\text { Morgan, 536 U.S. } \\
101 \text { (2002). }\end{array}$ & $\begin{array}{l}\text { Hostile environment claims include acts that are part of } \\
\text { practice beyond 300-day limitations. Dissent would time bar } \\
\text { each act individually. }\end{array}$ & $\begin{array}{l}\text { Employ ment, } \\
\text { liberal }\end{array}$ \\
\hline $\begin{array}{l}\text { Till v. SCS Credit } \\
\text { Corp., 541 U.S. } \\
\text { 465 (2004). }\end{array}$ & $\begin{array}{l}\text { Chapter 13 secured lender entitled to only interest rate of } \\
\text { prime plus risk (9.5\%) not cost of funds (21\%). Dissent } \\
\text { would give contract rate. }\end{array}$ & Business, liberal \\
\hline
\end{tabular}

\section{Appendix B8: Tables of Alito Composition Majorities Producing} More than Two 5-4 Opinions

We list the opinions of the United States Supreme Court while its composition is defined by its junior justice being Alito. The Alito composition consists of two appointees of Democratic presidents (Breyer and Ginsburg) and seven appointees of Republican presidents (Alito, Kennedy, Roberts, Scalia, Souter, Stevens, and Thomas). We list the majorities as they appear in the corresponding figure in the full-text proceeding clockwise from the nine o'clock position. The name of the case, along with the citation to the Supreme Court Reporter (not all United States Reporter citations were paginated at publication time), and the year appears in the first column. The second column holds our brief description of the outcome compared to the dissent's position. The third column holds the legal field and the political slant of the majority's position as it arises by juxtaposition to that of the minority. We sort the justices in the majorities by, first, the chief justice, then the associate justices by alphabetical order.

\section{BREYER-GINSBURG-KENNEDY-SOUTER-STEVENS (NINE O'CLOCK)}

\begin{tabular}{|l|l|l|}
\hline $\begin{array}{l}\text { M a r r m a v. } \\
\text { Citizens Bank, 549 } \\
\text { U.S. 365 (2007). }\end{array}$ & $\begin{array}{l}\text { Bankruptcy court had authority to block abusive attempt to } \\
\text { convert chapter 7 filing to chapter 13. Dissent (Alito with all), } \\
\text { right to convert is absolute. }\end{array}$ & $\begin{array}{l}\text { B u s i n e s s , } \\
\text { conservative }\end{array}$ \\
\hline $\begin{array}{l}\text { Mass. v. EPA, 549 } \\
\text { U.S. 497 (2007). }\end{array}$ & $\begin{array}{l}\text { Massachusetts has standing to ask EPA to regulate } \\
\text { greenhouse gases. Dissent (Roberts with all) "would reject } \\
\text { these challenges as nonjusticiable." }\end{array}$ & Admin, liberal \\
\hline $\begin{array}{l}\text { Abdul-Kabir v. v. } \\
\text { Quarterman, 550 } \\
\text { U.S. 233 (2007). }\end{array}$ & Identical to Brewer, 550 U.S. 286 (2007). & CrimPro, liberal \\
\hline
\end{tabular}




\begin{tabular}{|c|c|c|}
\hline $\begin{array}{l}\text { B r e w e r } \quad \mathrm{v} . \\
\text { Quarterman, } 550 \\
\text { U.S. } 286(2007)\end{array}$ & $\begin{array}{l}\text { Majority accepts habeas reversal of denial to allow jury to } \\
\text { hear some sentencing mitigating factors. Dissent (Roberts } \\
\text { with all), Antiterrorism and Effective Death Penalty Act } \\
\text { precluded the Court from reversing on such tenuous } \\
\text { precedent. }\end{array}$ & CrimPro, liberal \\
\hline $\begin{array}{l}\text { Smith v. Tex., } 550 \\
\text { U.S. } 297 \text { (2007). }\end{array}$ & $\begin{array}{l}\text { Death sentence review, second time, jury instructions } \\
\text { defective. Dissent (Alito with all), defendant's lawyer's failure } \\
\text { to object or correct instructions despite invitation from judge } \\
\text { precludes reversal. }\end{array}$ & CrimPro, liberal \\
\hline $\begin{array}{l}\text { P a n e t t i } \mathrm{v} . \\
\text { Quarterman, } 551 \\
\text { U.S. } 930(2007) .\end{array}$ & $\begin{array}{l}\text { Defendant incompetent to be executed. Dissent (Thomas with } \\
\text { all), defendant not entitled to second successive habeas } \\
\text { review. }\end{array}$ & CrimPro, liberal \\
\hline $\begin{array}{l}\text { Boumediene v. } \\
\text { Bush, } 553 \text { U.S. } 723 \\
(2008) \text {. }\end{array}$ & $\begin{array}{l}\text { Guantanamo detainees have habeas rights. Dissent } 1 \text { (Roberts } \\
\text { with Alito, Scalia, Thomas), "the system the political } \\
\text { branches constructed adequately protects any constitutional } \\
\text { rights . . enemy combatants may enjoy." Dissent } 2 \text { (Scalia } \\
\text { with Roberts, Alito, \& Thomas), "The writ of habeas corpus } \\
\text { does not, and never has, run in favor of aliens abroad." }\end{array}$ & CrimPro, liberal \\
\hline $\begin{array}{l}\text { Dada v. Mukasey, } \\
554 \text { U.S. } 1 \text { (2008). }\end{array}$ & $\begin{array}{l}\text { Deportable alien can withdraw voluntary withdrawal pending } \\
\text { other proceedings. Dissent } 1 \text { (Scalia with Roberts \& Thomas), } \\
\text { "the Court lacks the authority" to change the statutory } \\
\text { scheme; dissent } 2 \text { (Alito), Board of Immigration Appeals had } \\
\text { authority and its action is unclear, would remand. }\end{array}$ & $\begin{array}{l}\text { Immigration, } \\
\text { liberal }\end{array}$ \\
\hline $\begin{array}{l}\text { Sprint Commc'ns. } \\
\text { Co., LP v. APCC } \\
\text { Servs., } 554 \text { U.S. } \\
269 \text { (2008). }\end{array}$ & $\begin{array}{l}\text { Assignees of coin-operated phones can bring suit against } \\
\text { carriers. Dissent (Roberts with all), "Respondents have } \\
\text { nothing to gain from their lawsuit. Under settled principles of } \\
\text { standing, that fact requires dismissal of their complaint." }\end{array}$ & Business, liberal \\
\hline $\begin{array}{l}\text { Kennedy v. } \text { La., } \\
554 \text { U.S. } 407 \\
(2008) .\end{array}$ & $\begin{array}{l}\text { Rape with no death cannot lead to the death penalty. Dissent } \\
\text { (Alito with all), no basis for limitation. }\end{array}$ & CrimPro, liberal \\
\hline $\begin{array}{l}\text { Altria Group, Inc., } \\
\text { v. Good, } 555 \text { U.S. } \\
70 \text { (2008). }\end{array}$ & $\begin{array}{l}\text { Allows false advertising claim against cigarette makers under } \\
\text { Maine law. Dissent (Thomas with all), it is preempted by } \\
\text { federal legislation. }\end{array}$ & Business, liberal \\
\hline $\begin{array}{l}\text { Corley v. United } \\
\text { States, } 556 \text { U.S. } \\
303(2009) .\end{array}$ & $\begin{array}{l}\text { Suppresses confession. Dissent (Alito with all), "Unless the } \\
\text { unambiguous language of } \S 3501 \text { (a) is ignored, petitioner's } \\
\text { confession may not be suppressed." }\end{array}$ & CrimPro, liberal \\
\hline $\begin{array}{l}\text { H a y w o d } \mathrm{v} . \\
\text { Drown, } 556 \text { U.S. } \\
729(2009) .\end{array}$ & $\begin{array}{l}\text { State law limiting jurisdiction on prisoners' civil claims for } \\
\text { constitutional violation (1983) violated supremacy clause. } \\
\text { Dissent (Thomas with all), "neither the Constitution nor our } \\
\text { precedent requires New York to open its courts to } § 1983 \\
\text { federal actions." }\end{array}$ & CrimPro, liberal \\
\hline $\begin{array}{l}\text { Caperton, v. A. T. } \\
\text { Massey Coal Co., } \\
\text { Inc., } 556 \text { U.S. } 868 \\
(2009) .\end{array}$ & $\begin{array}{l}\text { Elected judge who received large donation from defendant- } \\
\text { appellant had recusal obligation. Dissent (Roberts with all), } \\
\text { mere "probability of bias" not enough. }\end{array}$ & CivPro, liberal \\
\hline $\begin{array}{l}\text { United States v. } \\
\text { Denedo, } 556 \text { U.S. } \\
904(2009) .\end{array}$ & $\begin{array}{l}\text { Military appellate court had jurisdiction to correct its error } \\
\text { allowing defendant to challenge conviction and delay } \\
\text { deportation. Dissent (Roberts with all), military courts do not } \\
\text { have jurisdiction to issue writs of coram nobis to correct their } \\
\text { judgments. }\end{array}$ & CrimPro, liberal \\
\hline
\end{tabular}




\section{GinsBuRG-SCALIA-SOUTER-STEVENS-THOMAS (TEN O'ClOCK)}

\begin{tabular}{|l|l|l|}
\hline $\begin{array}{l}\text { United States v. } \\
\text { Santos, 553 U.S. } \\
507 \text { (2008). }\end{array}$ & $\begin{array}{l}\text { Vacating money-laundering convictions on distinction of } \\
\text { profits from other receipts. Dissent 1 (Alito with all), } \\
\text { proceeds should include all. Dissent 2 (Breyer) would } \\
\text { distinguish money-laundering from crimes that include it as } \\
\text { operating gambling business, here. }\end{array}$ & Criml, liberal \\
\hline $\begin{array}{l}\text { Ariz. v. Gant, 556 } \\
\text { U.S. 332 (2009). }\end{array}$ & $\begin{array}{l}\text { (Drug-producing) search of vehicle following driver's arrest } \\
\text { improper if unjustified. Dissent (Alito with all), overruling } \\
\text { established precedent. Dissent 2 (Breyer), need better rule. }\end{array}$ & CrimPro, liberal \\
\hline $\begin{array}{l}\text { Melendez-Diaz v. } \\
\text { Mass., 557 U.S. } \\
305 \text { (2009). }\end{array}$ & $\begin{array}{l}\text { Admission of lab certificates that seized substance was } \\
\text { cocaine violated right to confront. Dissent (Kennedy with all), } \\
\text { overruling established admissibility of scientific testimony. }\end{array}$ & CrimPro, liberal \\
\hline
\end{tabular}

\section{RoBerTS-Alito-KenNEDY-SCALIA-THOMAS (THREE O'ClOCK)}

\begin{tabular}{|c|c|c|}
\hline $\begin{array}{l}\text { G a rcetti, } \\
\text { Ceballos, } 547 \text { U.S. } \\
410(2006) .\end{array}$ & $\begin{array}{l}\text { Public employees' work speech not protected by First } \\
\text { Amendment. Dissent } 1 \text { (Stevens), "it seems perverse to } \\
\text { fashion a new rule that provides employees with an incentive } \\
\text { to voice their concerns publicly before talking frankly to their } \\
\text { superiors." Dissent } 2 \text { (Souter with Stevens), "addressing } \\
\text { official wrongdoing and threats to health and safety" can } \\
\text { justify First Amendment protection. Dissent } 3 \text { (Breyer), } \\
\text { "courts should apply the Pickering standard, even though the } \\
\text { government employee speaks upon matters of public concern } \\
\text { in the course of his ordinary duties." }\end{array}$ & $\begin{array}{l}\text { A } \mathrm{d} \mathrm{m} \mathrm{i} \mathrm{n} \text {, } \\
\text { conservative }\end{array}$ \\
\hline $\begin{array}{l}\text { Hudson v. Mich., } \\
547 \text { U.S. } 586 \\
(2006) .\end{array}$ & $\begin{array}{l}\text { Violation of knock-and-announce rule did not require } \\
\text { suppression of all evidence. Dissent (Breyer with all), "the } \\
\text { Court destroys the strongest legal incentive to comply with } \\
\text { the Constitution's knock-and-announce requirement . . . } \\
\text { without significant support in precedent." }\end{array}$ & $\begin{array}{l}\mathrm{C} \text { r i m P r o, } \\
\text { conservative }\end{array}$ \\
\hline $\begin{array}{l}\text { Rapanos v. United } \\
\text { States, } 547 \text { U.S. } \\
715 \text { (2006). }\end{array}$ & $\begin{array}{l}\text { Land eleven to twenty miles from navigable waters was not } \\
\text { waters of the U.S. for Clean Water Act. Dissent } 1 \text { (Stevens } \\
\text { with all), "[r]ejecting more than } 30 \text { years of practice by the } \\
\text { Army Corps, the plurality disregards the nature of the } \\
\text { congressional delegation to the agency and the technical and } \\
\text { complex character of the issues at stake." Dissent } 2 \text { (Breyer), } \\
\text { courts must defer to Army Corps of Engineers definitions. }\end{array}$ & $\begin{array}{l}\text { A } \mathrm{d} \mathrm{m} \mathrm{i} \mathrm{n} \text {, } \\
\text { conservative }\end{array}$ \\
\hline
\end{tabular}




\begin{tabular}{|c|c|c|}
\hline $\begin{array}{l}\text { Kan. v. Marsh, } 548 \\
\text { U.S. } 163 \text { (2006). }\end{array}$ & $\begin{array}{l}\text { Kansas' death penalty statute satisfies the constitutional } \\
\text { mandates of Furman and its progeny because it rationally } \\
\text { narrows the class of death-eligible defendants and permits a } \\
\text { jury to consider any mitigating evidence relevant to its } \\
\text { sentencing determination. Dissent } 1 \text { (Stevens), "[n]othing } \\
\text { more than an interest in facilitating the imposition of the } \\
\text { death penalty in [Kansas] justified this Court's exercise of its } \\
\text { discretion to review the judgment of the [Kansas] Supreme } \\
\text { Court." Dissent } 2 \text { (Souter with all), "the Constitution forbids } \\
\text { a mandatory death penalty in what they describe as 'doubtful } \\
\text { cases,' when aggravating and mitigating factors are of equal } \\
\text { weight." }\end{array}$ & $\begin{array}{l}\mathrm{C} \mathrm{r} \text { i m } \mathrm{P} \mathrm{r} \mathrm{o} \text {, } \\
\text { conservative }\end{array}$ \\
\hline $\begin{array}{l}\text { League of United } \\
\text { Latin Am. Citizens } \\
\text { v. Perry, } 548 \text { U.S. } \\
399 \text { (2006). }\end{array}$ & $\begin{array}{l}\text { Redistricting, plurality, mostly affirms and remands } \\
\text { republican Texas plan. Dissent } 1 \text { (Stevens with Breyer) would } \\
\text { restore neutral plan of court before GOP gerrymander. } \\
\text { Dissent } 2 \text { (Souter with Ginsburg), "because . . . we have no } \\
\text { majority for any single criterion of impermissible } \\
\text { gerrymander [I treat this as] improvident grant of certiorari, } \\
\text { and add only two thoughts ... : that I do not ... flat[ly] } \\
\text { reject[] any test of gerrymander turning on the process } \\
\text { followed in redistricting, nor do I rule out the utility of a } \\
\text { criterion of symmetry as a test." Dissent } 3 \text { (Breyer), solely } \\
\text { partisan motivation violates equal protection. }\end{array}$ & $\begin{array}{l}\mathrm{V} \text { o t i n } \mathrm{g}, \\
\text { conservative }\end{array}$ \\
\hline $\begin{array}{l}\text { A y e r s } \quad \mathrm{v} . \\
\text { Belmontes, } 549 \\
\text { U.S. } 7 \text { (2006). }\end{array}$ & $\begin{array}{l}\text { Death habeas, jury not hearing some evidence mitigating the } \\
\text { penalty was not reversible. Dissent (Stevens with all), it was } \\
\text { reversible. }\end{array}$ & $\begin{array}{l}\mathrm{C} \mathrm{r} \mathrm{i} \mathrm{m} \mathrm{P} \mathrm{r} \mathrm{o,} \\
\text { conservative }\end{array}$ \\
\hline $\begin{array}{l}\text { Lawrence v. Fla., } \\
549 \text { U.S. } 327 \\
(2007) .\end{array}$ & $\begin{array}{l}\text { Death habeas, one-year limitation appropriate, no } \\
\text { extraordinary circumstances justifying tolling. Dissent } \\
\text { (Ginsburg with all) "would therefore hold that } 28 \text { U.S.C. § } \\
2244(d) \text { 's statute of limitations is tolled during the pendency } \\
\text { of a petition for certiorari." }\end{array}$ & $\begin{array}{l}\mathrm{C} \text { r i m P r o, } \\
\text { conservative }\end{array}$ \\
\hline $\begin{array}{l}\text { Gonzales v. } \\
\text { Carhart, } 550 \text { U.S. } \\
124 \text { (2007). }\end{array}$ & $\begin{array}{l}\text { Partial-birth abortion ban statute upheld. Dissent (Ginsburg } \\
\text { with all), "Today's decision is alarming. It refuses to take } \\
\text { Casey and Stenberg seriously. It tolerates, indeed applauds, } \\
\text { federal intervention to ban nationwide a procedure found } \\
\text { necessary and proper in certain cases by the American } \\
\text { College of Obstetricians and Gynecologists (ACOG). It blurs } \\
\text { the line, firmly drawn in Casey, between previability and } \\
\text { postviability abortions. And, for the first time since Roe, the } \\
\text { Court blesses a prohibition with no exception safeguarding a } \\
\text { woman's health." }\end{array}$ & $\begin{array}{l}\mathrm{S} \text { o } \mathrm{c} \text { i a } 1 \text {, } \\
\text { conservative }\end{array}$ \\
\hline $\begin{array}{l}\text { S c h ri ro } \\
\text { Landrigan, } 550 \\
\text { U.S. } 465 \text { (2007). }\end{array}$ & $\begin{array}{l}\text { Death habeas, ineffective counsel was not prejudicial. Dissent } \\
\text { (Stevens with all), "the Court holds that respondent is not } \\
\text { entitled to an evidentiary hearing to explore the prejudicial } \\
\text { impact of his counsel's inadequate representation [because it] } \\
\text { made no difference in the sentencing anyway ... [ [which] is } \\
\text { pure guesswork." }\end{array}$ & $\begin{array}{l}\mathrm{C} \mathrm{r} \mathrm{i} \mathrm{m} \mathrm{P} \mathrm{r} \mathrm{o,} \\
\text { conservative }\end{array}$ \\
\hline
\end{tabular}




\begin{tabular}{|c|c|c|}
\hline $\begin{array}{l}\text { Ledbetter v. } \\
\text { Goodyear Tire \& } \\
\text { Rubber Co., Inc., } \\
550 \text { U.S. } 618 \\
(2007) .\end{array}$ & $\begin{array}{l}\text { Pay discrimination time-barred, need immediate contest } \\
\text { within } 180 \text { days. Dissent (Ginsburg with all), "[t]he Court's } \\
\text { insistence on immediate contest overlooks common } \\
\text { characteristics of pay discrimination. Pay disparities often } \\
\text { occur, as they did in Ledbetter's case, in small increments." }\end{array}$ & $\begin{array}{l}\text { S o c i a } 1 \text {, } \\
\text { conservative }\end{array}$ \\
\hline $\begin{array}{l}\text { Uttecht v. Brown, } \\
551 \text { U.S. } 1 \text { (2007). }\end{array}$ & $\begin{array}{l}\text { Death habeas, elimination for cause of death-incapable juror } \\
\text { appropriate. Dissent (Stevens with all) disagrees, per } \\
\text { Wainwright. }\end{array}$ & $\begin{array}{l}\mathrm{C} \text { r i m P r o, } \\
\text { conservative }\end{array}$ \\
\hline $\begin{array}{l}\text { Fry v. Pliler, } 551 \\
\text { U.S. } 112(2007) \text {. }\end{array}$ & $\begin{array}{l}\text { Habeas review of exclusion of witness under milder Brecht } \\
\text { standard than "harmless beyond reasonable doubt." Dissent } \\
1 \text { (Stevens with all), should elaborate application of Brecht. } \\
\text { Dissent } 2 \text { (Breyer with Stevens), remand. }\end{array}$ & $\begin{array}{l}\mathrm{C} \text { r i m P r o, } \\
\text { conservative }\end{array}$ \\
\hline $\begin{array}{l}\text { Bowles v. Russell, } \\
551 \quad \text { U.S. } 205 \\
(2007) \text {. }\end{array}$ & $\begin{array}{l}\text { "[P]petitioner's untimely notice [of appeal] — even though } \\
\text { filed in reliance upon a District Court's order-deprived the } \\
\text { Court of Appeals of jurisdiction." Dissent (Souter with all), } \\
\text { "[t]he District Court told petitioner Keith Bowles that his } \\
\text { notice of appeal was due on February } 27,2004 \text {. He filed a } \\
\text { notice of appeal on February } 26 \text {, only to be told that he was } \\
\text { too late because his deadline had actually been February } 24 \text {. } \\
\text { It is intolerable for the judicial system to treat people this } \\
\text { way, and there is not even a technical justification for } \\
\text { condoning this bait and switch." }\end{array}$ & $\begin{array}{l}\mathrm{C} \text { r i m P r o, } \\
\text { conservative }\end{array}$ \\
\hline $\begin{array}{l}\text { Morse v. Frederick, } \\
551 \quad \text { U.S. } 393 \\
(2007) \text {. }\end{array}$ & $\begin{array}{l}\text { Student's banner at off-school sanctioned event was not } \\
\text { protected by First Amendment. Dissent (Breyer), need not } \\
\text { decide First Amendment issue, qualified immunity sufficient. } \\
\text { Dissent } 2 \text { (Stevens with Souter and Ginsburg), "it is a gross } \\
\text { non sequitur to draw . . . the remarkable conclusion that the } \\
\text { school may suppress student speech that was never meant to } \\
\text { persuade anyone to do anything." }\end{array}$ & $\begin{array}{l}\mathrm{S} \text { p e e c h, } \\
\text { conservative }\end{array}$ \\
\hline $\begin{array}{l}\text { Fed. Election } \\
\text { Comm'n v. Wisc. } \\
\text { Right to Life, Inc., } \\
551 \quad \text { U.S. } 449 \\
(2007) \text {. }\end{array}$ & $\begin{array}{l}\text { Campaign financing law limits on speech improper. Dissent } \\
\text { (Souter with all), decrying effective overruling of McConnell. }\end{array}$ & $\begin{array}{l}\mathrm{S} p \text { e e c h } \\
\text { conservative }\end{array}$ \\
\hline $\begin{array}{l}\text { Hein v. Freedom } \\
\text { From Religion } \\
\text { Found., Inc., } 551 \\
\text { U.S. } 587 \text { (2007). }\end{array}$ & $\begin{array}{l}\text { Plurality limits taxpayer standing to bring establishment } \\
\text { clause challenges. Dissent (Souter with all), "[t]he controlling } \\
\text { opinion closes the door on these taxpayers because the } \\
\text { Executive Branch, and not the Legislative Branch, caused } \\
\text { their injury. I see no basis for this distinction in either logic or } \\
\text { precedent." }\end{array}$ & $\begin{array}{l}\mathrm{R} \text { e } 1 \text { i g i o } \mathrm{n}, \\
\text { conservative }\end{array}$ \\
\hline $\begin{array}{l}\text { Nat'l Ass'n of } \\
\text { Home Builders, v. } \\
\text { Def. of Wildlife, } \\
551 \text { U.S. } 644 \\
(2007) \text {. }\end{array}$ & $\begin{array}{l}\text { EPA's transfer of authority to state proper (Clean Water and } \\
\text { Endangered Species Acts). Dissent } 1 \text { (Stevens with all), } \\
\text { interpretation is "fundamentally inconsistent with the ESA." } \\
\text { Dissent } 2 \text { (Breyer), "majority cannot possibly be correct in } \\
\text { concluding that the structure of } \S 402 \text { (b) precludes } \\
\text { application of } \S 7(a)(2) \text { to the EPA's discretionary action." }\end{array}$ & $\begin{array}{l}\text { E } \mathrm{n} \mathrm{v} \text { i } \mathrm{r}, 1 \\
\text { conservative }\end{array}$ \\
\hline
\end{tabular}




\begin{tabular}{|c|c|c|}
\hline $\begin{array}{l}\text { Parents Involved In } \\
\text { Cmty. Sch. v. } \\
\text { Seattle Sch. Dist. } \\
\text { No. } 1,551 \text { U.S. } \\
701 \text { (2007). }\end{array}$ & $\begin{array}{l}\text { Plurality invalidates integration/affirmative action policy in } \\
\text { schools. Dissent } 1 \text { (Stevens), "[t]here is a cruel irony in THE } \\
\text { CHIEF JUSTICE's reliance on our decision in Brown v. } \\
\text { Board." Dissent } 2 \text { (Breyer with all), the plurality "distorts } \\
\text { precedent, it misapplies the relevant constitutional principles, } \\
\text { it announces legal rules that will obstruct efforts by state and } \\
\text { local governments to deal effectively with the growing } \\
\text { resegregation of public schools, it threatens to substitute for } \\
\text { present calm a disruptive round of race-related litigation, and } \\
\text { it undermines Brown's promise of integrated primary and } \\
\text { secondary education." }\end{array}$ & $\begin{array}{l}\mathrm{S} \text { o c i a } 1 \text {, } \\
\text { conservative }\end{array}$ \\
\hline $\begin{array}{l}\text { Leegin Creative } \\
\text { Leather Prod., Inc. } \\
\text { v. PSKS, Inc., } 551 \\
\text { U.S. } 877 \text { (2007). }\end{array}$ & $\begin{array}{l}\text { Vertical price maintenance agreements are not per se antitrust } \\
\text { violations. Dissent (Breyer with all), should not overturn } D r \text {. } \\
\text { Miles. }\end{array}$ & $\begin{array}{l}\text { B u s i n e s s, } \\
\text { conservative }\end{array}$ \\
\hline $\begin{array}{l}\text { Plains Commerce } \\
\text { Bank v. Long } \\
\text { Family Land \& } \\
\text { Cattle Co., } 554 \\
\text { U.S. } 316 \text { (2008). }\end{array}$ & $\begin{array}{l}\text { Takes jurisdiction and disallows discrimination award against } \\
\text { bank from tribal court. Dissent (Ginsburg with all) would } \\
\text { allow the discrimination award. }\end{array}$ & $\begin{array}{l}\mathrm{T} \text { r i b a } 1 \text {, } \\
\text { conservative }\end{array}$ \\
\hline $\begin{array}{l}\text { v. Heller, } 554 \\
570 \text { (2008). }\end{array}$ & $\begin{array}{l}\text { Second Amendment gives individual right. Dissent } 1 \text { (Stevens } \\
\text { with all) would adhere to Miller (1939). Dissent } 2 \text { (Breyer } \\
\text { with all), even if Second Amendment gives individual right, } \\
\text { D.C. could regulate. }\end{array}$ & $\begin{array}{l}\text { Gun rights, } \\
\text { conservative }\end{array}$ \\
\hline $\begin{array}{l}\text { Davis v. Fed. } \\
\text { Election Cmty., } \\
554 \text { U.S. } 724 \\
(2008) \text {. }\end{array}$ & $\begin{array}{l}\text { Campaign finance law bonuses to opponents of self-funded } \\
\text { wealthy candidates ("Millionaire's amendment") violate First } \\
\text { Amendment. Dissent } 1 \text { (Stevens with all), Massachusetts } \\
\text { consistent with McConnell, reasonable. Dissent } 2 \text { (Ginsburg } \\
\text { with Breyer) does not join Stevens about Buckley. }\end{array}$ & $\begin{array}{l}\mathrm{S} p \text { e e c h } \\
\text { conservative }\end{array}$ \\
\hline $\begin{array}{l}\text { Medellin v. } \text { Tex., } \\
554 \text { U.S. } 759 \\
(2008) .\end{array}$ & $\begin{array}{l}\text { Death habeas, violation of right to consular access is not } \\
\text { grounds for habeas. Dissent (individuals, all), easy to comply } \\
\text { with mere notice, no reason to denigrate ICJ and Geneva } \\
\text { convention. }\end{array}$ & $\begin{array}{l}\mathrm{C} \mathrm{r} \text { i m P r o, } \\
\text { conservative }\end{array}$ \\
\hline $\begin{array}{l}\text { Herring v. United } \\
\text { States, } 555 \text { U.S. } \\
135 \text { (2009). }\end{array}$ & $\begin{array}{l}\text { Meth and firearm possession conviction, police } \\
\text { recordkeeping error not grounds for suppression. Dissent } 1 \\
\text { (Ginsburg with all), exclusionary rule should apply to police } \\
\text { negligence, not only intentional misconduct. Dissent } 2 \\
\text { (Breyer with Souter), precedent excuses recordkeeping errors } \\
\text { by other bodies, not police. }\end{array}$ & $\begin{array}{l}\mathrm{C} \mathrm{r} \mathrm{i} \mathrm{m} \mathrm{P} \mathrm{r} \mathrm{o,} \\
\text { conservative }\end{array}$ \\
\hline $\begin{array}{l}\text { Summers v. Earth } \\
\text { Island Inst., } 555 \\
\text { U.S. } 488(2009) \text {. }\end{array}$ & $\begin{array}{l}\text { Environmental organization has no standing to challenge } \\
\text { EPA land disposition. Dissent (By with all), "[n]othing in the } \\
\text { record or the law justifies this counterintuitive conclusion." }\end{array}$ & $\begin{array}{l}\text { A } \mathrm{d} \mathrm{m} \mathrm{i} n \text {, } \\
\text { conservative }\end{array}$ \\
\hline
\end{tabular}




\begin{tabular}{|c|c|c|}
\hline $\begin{array}{l}\text { B a r t e t t } \\
\text { Strickland, }\end{array}$ & $\begin{array}{l}\text { Redistricting, plurality. Dissent } 1 \text { (Souter with all), "[t]he } \\
\text { question in this case is whether a minority with under } 50 \% \text { of } \\
\text { the voting population of a proposed voting district can ever } \\
\text { qualify under } \S 2 \text { of the Voting Rights Act of } 1965 \text { (VRA) as } \\
\text { residents of a putative district whose minority voters would } \\
\text { have an opportunity 'to elect representatives of their choice.' } \\
42 \text { U.S.C. } \S 1973 \text { (b) ( } 2000 \text { ed.). If the answer is no, minority } \\
\text { voters in such a district will have no right to claim relief } \\
\text { under } \S 2 \text { from a statewide districting scheme that dilutes } \\
\text { minority voting rights. I would hold that the answer in law as } \\
\text { well as in fact is sometimes yes: a district may be a minority- } \\
\text { opportunity district so long as a cohesive minority population } \\
\text { is large enough to elect its chosen candidate when combined } \\
\text { with a reliable number of crossover voters from an otherwise } \\
\text { polarized majority." Dissent } 2 \text { (Ginsburg), "[t]he plurality's } \\
\text { interpretation of } \S 2 \text { of the Voting Rights Act of } 1965 \text { is } \\
\text { difficult to fathom and severely undermines the statute's } \\
\text { estimable aim." Dissent } 3 \text { (Breyer), "I write separately in light } \\
\text { of the plurality's claim that a bright-line } 50 \% \text { rule . . serves } \\
\text { administrative objectives. In the plurality's view, that rule } \\
\text { amounts to a relatively simple administrative device that will } \\
\text { help separate at the outset those cases that are more likely } \\
\text { meritorious from those that are not. Even were that objective } \\
\text { as critically important as the plurality believes, however, it is } \\
\text { not difficult to find other numerical gateway rules that would } \\
\text { work better." }\end{array}$ & $\begin{array}{l}\mathrm{V} \text { o t i n } \mathrm{g}, \\
\text { conservative }\end{array}$ \\
\hline $\begin{array}{l}\text { Entergy Corp. v. } \\
\text { Riverkeeper, Inc., } \\
556 \text { U.S. } 208 \\
(2009) \text {. }\end{array}$ & $\begin{array}{l}\text { The EPA permissibly relied on cost-benefit analysis in setting } \\
\text { the national performance standards and in providing for cost- } \\
\text { benefit variances from those standards. Dissent } 1 \text { (Breyer), } \\
\text { "the drafting history and legislative history . . . makes clear } \\
\text { that those who sponsored the legislation intended the law's } \\
\text { text to be read as restricting, though not forbidding, the use of } \\
\text { cost-benefit comparisons." Dissent } 2 \text { (Stevens with Ginsburg } \\
\text { and Souter), "Like the Court of Appeals, I am convinced that } \\
\text { the EPA has misinterpreted the plain text of } \S 316(\text { b). Unless } \\
\text { costs are so high that the best technology is not 'available,' } \\
\text { Congress has decided that they are outweighed by the } \\
\text { benefits of minimizing adverse environmental impact." }\end{array}$ & $\begin{array}{l}\mathrm{E} \mathrm{n} \mathrm{v} \mathrm{i} \mathrm{r}, 1, \\
\text { conservative }\end{array}$ \\
\hline $\begin{array}{l}14 \text { Penn Plaza LLC } \\
\text { v. Pyett, } 556 \text { U.S. } \\
247 \text { (2009). }\end{array}$ & $\begin{array}{l}\text { Collective bargaining agreement clause to arbitrate age- } \\
\text { discrimination claims is enforceable. Dissent } 1 \text { (Stevens) } \\
\text { bemoans court's favoring of arbitration. Dissent } 2 \text { (Souter } \\
\text { with all) "would adhere to stare decisis" and continue to allow } \\
\text { suit. }\end{array}$ & $\begin{array}{l}\text { Employment, } \\
\text { conservative }\end{array}$ \\
\hline
\end{tabular}




\begin{tabular}{|c|c|c|}
\hline $\begin{array}{l}\text { FCC V. Fox } \\
\text { Television Stations, } \\
\text { Inc., } 556 \text { U.S. } 502 \\
(2009) .\end{array}$ & $\begin{array}{l}\text { FCC adoption of single use of expletive is punishable is } \\
\text { appropriate. Dissent } 1 \text { (Stevens) would "favor stability over } \\
\text { administrative whim." Dissent } 2 \text { (Ginsburg), "there is no way } \\
\text { to hide the long shadow the First Amendment casts over what } \\
\text { the Commission has done." Dissent } 3 \text { (By with all) the FCC } \\
\text { "failed adequately to explain why it changed its indecency } \\
\text { policy ... instead discussed several factors well known to it } \\
\text { the first time around ... is 'arbitrary, capricious, an abuse of } \\
\text { discretion. "' }\end{array}$ & $\begin{array}{l}\mathrm{S} \text { o c i a } 1 \text {, } \\
\text { conservative }\end{array}$ \\
\hline $\begin{array}{l}\text { Ashcroft v. Iqbal, } \\
556 \text { U.S. } 662 \\
(2009) .\end{array}$ & $\begin{array}{l}\text { Arab pretrial detainee failed to state a claim. Dissent } 1 \\
\text { (Souter with all) "dissent[s] from both the rejection of } \\
\text { supervisory liability as a cognizable claim in the face of } \\
\text { petitioners' concession, and from the holding that the } \\
\text { complaint fails to [state a claim]." Dissent } 2 \text { (Breyer), } \\
\text { alternative measures to prevent "unwarranted litigation" } \\
\text { against government officials exist. }\end{array}$ & $\begin{array}{l}\mathrm{C} \mathrm{r} \text { i m P r o, } \\
\text { conservative }\end{array}$ \\
\hline $\begin{array}{l}\text { Montejo v. La., } 556 \\
\text { U.S. } 778 \text { (2009). }\end{array}$ & $\begin{array}{l}\text { Defendant's silence at pretrial hearing does not allow } \\
\text { suppression as he did not request a lawyer. Dissent } 1 \text { (Stevens } \\
\text { with all), "without any evidence that the longstanding Sixth } \\
\text { Amendment protections established in Jackson have caused } \\
\text { any harm to the workings of the criminal justice system, the } \\
\text { Court rejects Jackson ..." Dissent } 2 \text { (Breyer), court is bound } \\
\text { by stare decisis. }\end{array}$ & $\begin{array}{l}\mathrm{C} r \mathrm{i} \mathrm{m} \mathrm{P} \mathrm{r} \mathrm{o,} \\
\text { conservative }\end{array}$ \\
\hline $\begin{array}{l}\text { Dist. Atty's Office } \\
\text { for the Third } \\
\text { Judicial Dist. v. } \\
\text { Osborne, } 557 \text { U.S. } \\
52 \text { (2009). }\end{array}$ & $\begin{array}{l}\text { Postconviction access to DNA up to legislature, not court, } \\
\text { Alaska's procedures reasonable. Dissent } 1 \text { (Stevens with all), } \\
\text { "the Court today blesses the State's arbitrary denial of the } \\
\text { evidence Osborne seeks." Dissent } 2 \text { (Souter) would not reach } \\
\text { Fourteenth Amendment claim of access to evidence. }\end{array}$ & $\begin{array}{l}\mathrm{C} r \mathrm{i} \mathrm{m} \mathrm{P} \mathrm{ro} \text {, } \\
\text { conservative }\end{array}$ \\
\hline $\begin{array}{l}\text { Gross v. FBL Fin. } \\
\text { Servs., Inc., } 557 \\
\text { U.S. } 167 \text { (2009). }\end{array}$ & $\begin{array}{l}\text { Age-discrimination plaintiff needs to show age was but for } \\
\text { cause of demotion. Dissent } 1 \text { (Stevens with all), "The most } \\
\text { natural reading of this statutory text prohibits adverse } \\
\text { employment actions motivated in whole or in part by the age } \\
\text { of the employee." Dissent } 2 \text { (Breyer with Souter \& Ginsburg), } \\
\text { "The words 'because of do not inherently require a showing } \\
\text { of 'but-for' causation, and I see no reason to read them to } \\
\text { require such a showing." }\end{array}$ & $\begin{array}{l}\text { Business/Employ } \\
m \text { e n t , } \\
\text { conservative }\end{array}$ \\
\hline
\end{tabular}




\begin{tabular}{|c|c|c|}
\hline $\begin{array}{l}\text { Horne v. Flores, } \\
557 \text { U.S. } 433 \\
(2009) .\end{array}$ & $\begin{array}{l}\text { "Arizona is now fulfilling its statutory obligation [to help } \\
\text { students who need English language instruction] by new } \\
\text { means that reflect new policy insights and other changed } \\
\text { circumstances." Dissent (Breyer with all) disagrees with } \\
\text { court's standard for institutional reform litigation, standard } \\
\text { met anyway. }\end{array}$ & $\begin{array}{l}\mathrm{S} \text { o c i a } 1, \\
\text { conservative }\end{array}$ \\
\hline $\begin{array}{l}\text { Ricci v. DeStefano, } \\
557 \quad \text { U.S. } \quad 557 \\
(2009) .\end{array}$ & $\begin{array}{l}\text { City must certify results of test for firefighters that city } \\
\text { resisted b/c results may expose it to disparate impact liability. } \\
\text { Dissent (Ginsburg with all), "the Court pretends that '[t]he } \\
\text { City rejected the test results solely because the higher scoring } \\
\text { candidates were white.' That pretension, essential to the } \\
\text { Court's disposition, ignores substantial evidence of multiple } \\
\text { flaws in the tests New Haven used. The Court similarly fails } \\
\text { to acknowledge the better tests used in other cities, which } \\
\text { have yielded less racially skewed outcomes." }\end{array}$ & $\begin{array}{l}\mathrm{S} \text { o c i a } 1, \\
\text { conservative }\end{array}$ \\
\hline
\end{tabular}

\section{GINSBURG-BREYER-SCALIA-SOUTER-THOMAS (EIGHT O'CLOCK)}

\begin{tabular}{|l|l|l|l|}
\hline $\begin{array}{l}\text { United States v. } \\
\text { Gonzalez-Lopez, } \\
548 \text { U.S. 140 } \\
(2006) .\end{array}$ & $\begin{array}{l}\text { Court's denial of pro hac vice attorney entitled defendant to } \\
\text { reversal. Dissent (Alito with all), "defendant should be } \\
\text { required to make at least some showing that the trial court's } \\
\text { erroneous ruling adversely affected the quality of assistance } \\
\text { that the defendant received." }\end{array}$ & CrimPro, liberal \\
\hline $\begin{array}{lll}\text { Spears } \quad \text { v. United } \\
\text { States, 555 U.S. } \\
261(2009) .\end{array}$ & $\begin{array}{l}\text { Per curiam affirmance of lower court's deviation from 100:1 } \\
\text { ratio for penalty for crack cocaine (viz. powder) as guidelines } \\
\text { are merely advisory. Dissent 1 (Kennedy) would grant oral } \\
\text { argument. Dissent 2 (Thomas) disagrees. Dissent 3 (Roberts } \\
\text { with Alito) "do[es] not think any error is so apparent as to } \\
\text { warrant the bitter medicine of summary reversal, and I think } \\
\text { there are good reasons not to address the question presented." }\end{array}$ & CrimPro, liberal \\
\hline $\begin{array}{l}\text { Cuomo v. The } \\
\text { Clearing House } \\
\text { Ass'n, LLC, 557 }\end{array}$ & $\begin{array}{l}\text { Majority allows New York state attorney general to bring } \\
\text { enforcement actions for New York law on bank lending } \\
\text { practices. Dissent (Thomas with all) would defer to agency's } \\
\text { interpretation that state actions are preempted. }\end{array}$ & Business, liberal \\
\hline
\end{tabular}

\section{Appendix B9: Tables of Kagan Composition Majorities Producing More than Two 5-4 Opinions}

We list the opinions of the United States Supreme Court while its composition is defined by its junior justice being Kagan. The Kagan composition consists of four appointees of Democratic presidents (Breyer, Ginsburg, Kagan, and Sotomayor) and five appointees of Republican presidents (Alito, Kennedy, Roberts, Scalia, and Thomas).

We list the majorities as they appear in the corresponding figure in the fulltext proceeding clockwise from the nine o'clock position. The name of the case, along with the citation to the Supreme Court Reporter (not all United States Reporter citations were paginated at publication time), and the year appears in the first column. The second column holds our brief description of the outcome compared to the dissent's position. The third column holds the legal field and the political slant of the majority's position as it arises by juxtaposition to that of the 
minority. We sort the justices in the majorities by, first, the chief justice, then the associate justices by alphabetical order.

\section{BREYER-GINSBURG-KAGAN-KENNEDY-SOTOMAYOR (NINE O'CLOCK)}

\begin{tabular}{|c|c|c|}
\hline $\begin{array}{l}\text { Brown v. Plata, } \\
131 \text { S. Ct. } 1910 \\
(2011) .\end{array}$ & $\begin{array}{l}\text { Affirming remedy for overcrowding of prison population. } \\
\text { Dissent } 1 \text { (Scalia with Thomas), order to release } 46,000 \\
\text { felons outrageous. Dissent } 2 \text { (Alito with Roberts), lower court } \\
\text { exceeded its authority. }\end{array}$ & Admin, liberal \\
\hline $\begin{array}{l}\text { J. D. B. v. N.C., } \\
131 \text { S. Ct. } 2394 \\
(2011) .\end{array}$ & $\begin{array}{l}\text { Should have Mirandized 13-year-old. Dissent (Alito with all), } \\
\text { child was not in true custody. }\end{array}$ & CrimPro, liberal \\
\hline $\begin{array}{l}\text { Turner v. Rogers, } \\
131 \text { S. Ct. } 2507 \\
(2011) \text {. }\end{array}$ & $\begin{array}{l}\text { Incarceration over back child support without counsel } \\
\text { violated due process. Dissent (Thomas with all), no right to } \\
\text { counsel in civil proceedings. }\end{array}$ & CrimPro, liberal \\
\hline $\begin{array}{l}\text { Freeman v. United } \\
\text { States, } 131 \text { S. Ct. } \\
2685(2011) \text {. }\end{array}$ & $\begin{array}{l}\text { Plurality: Reduction of cocaine guidelines applies to pleas. } \\
\text { Dissent (Roberts with all), pleas "take the bitter with the } \\
\text { sweet." }\end{array}$ & CrimPro, liberal \\
\hline $\begin{array}{l}\text { Douglas v. Indep. } \\
\text { Living Ctr. of S. } \\
\text { Cal., Inc., } 132 \mathrm{~S} \text {. } \\
\text { Ct. } 1204 \text { (2012). }\end{array}$ & $\begin{array}{l}\text { Remands to determine proper Medicaid payments to } \\
\text { providers. Dissent (Roberts with all), providers do not have } \\
\text { standing. }\end{array}$ & Health, liberal \\
\hline $\begin{array}{l}\text { Lafler v. Cooper, } \\
132 \text { S. Ct. } 1376 \\
(2012) \text {. }\end{array}$ & $\begin{array}{l}\text { Habeas, ineffective assistance of counsel, vacated for new } \\
\text { plea offer. Dissent } 1 \text { (Scalia with Thomas \& Roberts), } \\
\text { "Today's decision upends decades of our cases, violates a } \\
\text { federal statute, and opens a whole new boutique of } \\
\text { constitutional jurisprudence ('plea-bargaining law') without } \\
\text { even specifying the remedies the boutique offers." Dissent } 2 \\
\text { (Alito), no basis for prejudice. }\end{array}$ & CrimPro, liberal \\
\hline $\begin{array}{l}\text { Missouri v. Frye, } \\
132 \text { S. Ct. } 1399 \\
(2012) .\end{array}$ & $\begin{array}{l}\text { Fourth driving while revoked, felony, plea offer should have } \\
\text { been transmitted. Dissent (Scalia with all), "The plea- } \\
\text { bargaining process is a subject worthy of regulation, since it } \\
\text { is the means by which most criminal convictions are } \\
\text { obtained. It happens not to be, however, a subject covered by } \\
\text { the Sixth Amendment, which is concerned not with the } \\
\text { fairness of bargaining but with the fairness of conviction." }\end{array}$ & CrimPro, liberal \\
\hline $\begin{array}{l}\text { Dorsey v. United } \\
\text { States, } 132 \text { S. Ct. } \\
2321(2012) \text {. }\end{array}$ & $\begin{array}{l}\text { Retroactive benefits of crack cocaine penalty adjustments. } \\
\text { Dissent (Scalia with all), new sentences are not retroactive. }\end{array}$ & CrimPro, liberal \\
\hline $\begin{array}{l}\text { Miller v. Alabama, } \\
132 \text { S. Ct. } 2455 \\
(2012) \text {. }\end{array}$ & $\begin{array}{l}\text { Plurality: Life sentence for underage cruel and unusual. } \\
\text { Dissent } 1 \text { (Roberts with all), apply the law, don't make up } \\
\text { social policy. Dissent } 2 \text { (Thomas with Scalia), not consistent } \\
\text { with original understanding of cruel and unusual. }\end{array}$ & CrimPro, liberal \\
\hline $\begin{array}{l}\text { US Airways, Inc. v. } \\
\text { McCutchen, } 133 \text { S. } \\
\text { Ct. } 1537 \text { (2013). }\end{array}$ & $\begin{array}{l}\text { Insured owes recovery minus atty fees to self-insuring } \\
\text { employer. Dissent (Scalia with all), the text of the agreement } \\
\text { was net of atty fees. }\end{array}$ & Business, liberal \\
\hline $\begin{array}{l}\text { McQuiggin v. } \\
\text { Perkins, } 133 \text { S. Ct. } \\
1924 \text { (2013). }\end{array}$ & $\begin{array}{l}\text { Habeas, actual innocence overrides limitations periods. } \\
\text { Dissent (Scalia with all), court overrides text of statute. }\end{array}$ & CrimPro, liberal \\
\hline
\end{tabular}




\begin{tabular}{|c|c|c|}
\hline $\begin{array}{l}\text { Trevino v. Thaler, } \\
133 \text { S. Ct. } 1911 \\
(2013) \text {. }\end{array}$ & $\begin{array}{l}\text { Habeas, can raise claims. Dissent } 1 \text { (Roberts with Alito), "The } \\
\text { questions raised by this equitable equation are as endless as } \\
\text { will be the state-by-state litigation it takes to work them out." } \\
\text { Dissent } 2 \text { (Scalia with Thomas), just like Martinez. }\end{array}$ & CrimPro, liberal \\
\hline $\begin{array}{l}\text { Peugh v. United } \\
\text { States, } 133 \text { S. Ct. } \\
2072(2013) \text {. }\end{array}$ & $\begin{array}{l}\text { Plurality: Defendant entitled to more lenient guidelines at } \\
\text { time of crime. Dissent (Thomas with all), "The retroactive } \\
\text { application of the } 2009 \text { Guidelines did not alter the } \\
\text { punishment affixed to petitioner's crime and does not violate } \\
\text { this proscription." }\end{array}$ & CrimPro, liberal \\
\hline $\begin{array}{l}\text { United States v. } \\
\text { Windsor, } 133 \text { S. Ct. } \\
2675(2013) .\end{array}$ & $\begin{array}{l}\text { Same-sex spouses entitled to benefits. Dissent } 1 \text { (Roberts), } \\
\text { DOMA constitutional, no jurisdiction. Dissent } 2 \text { (Scalia with } \\
\text { Thomas and Roberts), no jurisdiction. Dissent } 3 \text { (Alito with } \\
\text { Thomas), Constitution not for same-sex marriage. }\end{array}$ & Social, liberal \\
\hline $\begin{array}{l}\text { Hall v. Fla., } 134 \text { S. } \\
\text { Ct. } 1986 \text { (2014). }\end{array}$ & $\begin{array}{l}\text { Death; Florida should explore mental disability more. Dissent } \\
\text { (Alito with all), the court "adopts a uniform national rule that } \\
\text { is both conceptually unsound and likely to result in } \\
\text { confusion." }\end{array}$ & CrimPro, liberal \\
\hline $\begin{array}{l}\text { Abramski v. United } \\
\text { States, } 134 \text { S. Ct. } \\
2259 \text { (2014). }\end{array}$ & $\begin{array}{l}\text { Upholds misrepresentation convictions of buying gun for } \\
\text { other; Dissent (Scalia with all), not per statutory language. }\end{array}$ & Gun rights, liberal \\
\hline $\begin{array}{l}\text { Ala. Legislative } \\
\text { Black Caucus v. } \\
\text { Ala., } 135 \text { S. Ct. } \\
1257(2015) .\end{array}$ & $\begin{array}{l}\text { Redistricting, remands majority-minority districting for } \\
\text { merely preserving majority-minority percentages. Dissent } 1 \\
\text { (Scalia with Roberts, Thomas, \& Alito), court allows } \\
\text { appellants "to take a mulligan, remanding the case with orders } \\
\text { that the District Court consider whether some (all?) of } \\
\text { Alabama's } 35 \text { majority-minority districts result from } \\
\text { impermissible racial gerrymandering." Dissent } 2 \text { (Thomas), } \\
\text { "[F]ew devices could be better designed to exacerbate racial } \\
\text { tensions than the consciously segregated districting system } \\
\text { currently being constructed in the name of the Voting Rights } \\
\text { Act." }\end{array}$ & Voting, liberal \\
\hline $\begin{array}{l}\text { United States v. } \\
\text { Kwai Fun Wong, } \\
135 \text { S. Ct. } 1625 \\
(2015) \text {. }\end{array}$ & $\begin{array}{l}\text { Limitations of Fed Tort Claims Act are subject to tolling; } \\
\text { dissent (A with all) "The statutory text, its historical roots, } \\
\text { and more than a century of precedents show that this absolute } \\
\text { bar is not subject to equitable tolling." }\end{array}$ & Business, liberal \\
\hline $\begin{array}{l}\text { Tex. Dep't of Hous. } \\
\& \text { Cmty. Affairs v. } \\
\text { I n c } 1 \text { u s i v e } \\
\text { C o m m u n it i e s } \\
\text { Project, Inc., } 135 \text { S. } \\
\text { Ct. } 2507 \text { (2015). }\end{array}$ & $\begin{array}{l}\text { Federal Housing Act allows disparate-impact claims. Dissent } \\
1 \text { (Thomas), disparate-impact "foundation ... is made of } \\
\text { sand." Dissent } 2 \text { (Alito with all), "The Fair Housing Act does } \\
\text { not create disparate-impact liability, nor do this Court's } \\
\text { precedents." }\end{array}$ & Social, liberal \\
\hline 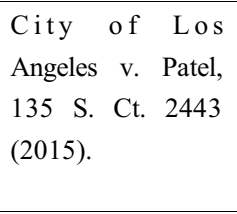 & $\begin{array}{l}\text { Motel challenge to LA ordinance on guest information } \\
\text { availability violates Fourth Amendment. Dissent } 1 \text { (Scalia } \\
\text { with all), need deterrence, judicial inspection too } \\
\text { burdensome. Dissent } 2 \text { (Alito with Thomas), five examples of } \\
\text { constitutional searches of registers. }\end{array}$ & CrimPro, liberal \\
\hline $\begin{array}{l}\text { Brumfield v. Cain, } \\
135 \text { S. Ct. } 2269 \\
(2015) .\end{array}$ & $\begin{array}{l}\text { Death habeas; IQ of seventy-five needs more procedural } \\
\text { protections. Dissent } 1 \text { (Thomas with all), the court oversteps } \\
\text { habeas limits. Dissent } 2 \text { (Alito with Roberts), story Thomas } \\
\text { recounts is not essential. }\end{array}$ & CrimPro, liberal \\
\hline
\end{tabular}




\begin{tabular}{|l|l|l|l|}
\hline K in g s ley r. & Pretrial detainee need only show force was objectively & CrimPro, liberal \\
Hendrickson, 135 & unreasonable. Dissent 1 (Scalia with Roberts \& Thomas), \\
S. Ct. 2466 (2015). & $\begin{array}{l}\text { only standard should be Fourteenth Amendment, due process } \\
\text { \& no. Dissent 2 (Alito), should dismiss as improvidently } \\
\text { granted and decide if pretrial detainee can bring Fourth } \\
\text { Amendment claim. }\end{array}$ & \\
\hline $\begin{array}{l}\text { Obergefell v. } \\
\text { Hodges, 135 S. Ct. } \\
2584(2015) .\end{array}$ & Same-sex marriage right; four dissents disagree. & Social, liberal \\
\hline
\end{tabular}

\section{BREYER-GINSBURG-KAGAN-SOTOMAYOR-THOMAS (TEN O'CLOCK)}

\begin{tabular}{|c|c|c|}
\hline $\begin{array}{l}\text { CSX Transp., Inc. } \\
\text { v. McBride, } 131 \mathrm{~S} \text {. } \\
\text { Ct. } 2630(2011) .\end{array}$ & $\begin{array}{l}\text { For liability in favor of employee under Federal Employer } \\
\text { Liability Act need to merely show employer's negligence, not } \\
\text { proximate causation. Dissent (Roberts with all), need } \\
\text { proximate cause. }\end{array}$ & Business, liberal \\
\hline $\begin{array}{l}\text { Alleyne v. United } \\
\text { States, } 133 \text { S. Ct. } \\
2151 \text { (2013). }\end{array}$ & $\begin{array}{l}\text { Plurality: Factors increasing mandatory minimum are } \\
\text { elements of crime that need beyond reasonable doubt proof to } \\
\text { jury. Dissent } 1 \text { (Roberts with Scalia and Kennedy), legislative } \\
\text { imposition should not trigger different consequences than } \\
\text { judicial discretion. Dissent } 2 \text { (Alito), overruling precedent but } \\
\text { should be overruling Apprendi. }\end{array}$ & CrimPro, liberal \\
\hline $\begin{array}{l}\text { Walker v. Tex. } \\
\text { Div., Sons of } \\
\text { Con fe de r a t e } \\
\text { Veterans, Inc., } 135 \\
\text { S. Ct. } 2239 \text { (2015). }\end{array}$ & $\begin{array}{l}\text { License plate is government speech and citizens have no right } \\
\text { to have the confederate flag on the license plate. Dissent } \\
\text { (Alito with all), majority threatens speech that the } \\
\text { government finds displeasing. }\end{array}$ & Speech, liberal \\
\hline
\end{tabular}

\section{ROBERTS-ALITO-KENNEDY-SCALIA-THOMAS (THREE O'CLOCK)}

\begin{tabular}{|c|c|c|}
\hline $\begin{array}{l}\text { Connick v. } \\
\text { Thompson, } 131 \text { S. } \\
\text { Ct. } 1350 \text { (2011). }\end{array}$ & $\begin{array}{l}\text { Plurality: Single DA error does not create } \S 1983 \text { liability for } \\
\text { failure to train. Dissent (Ginsburg with all), "long-concealed } \\
\text { prosecutorial transgressions were neither isolated nor } \\
\text { atypical." }\end{array}$ & $\begin{array}{l}\text { S o c i a } 1 \\
\text { conservative }\end{array}$ \\
\hline $\begin{array}{l}\text { Ariz. Christian Sch. } \\
\text { Tuition Org. v. } \\
\text { Winn, } 131 \text { S. Ct. } \\
1436(2011) .\end{array}$ & $\begin{array}{l}\text { Plurality: Taxpayers lacked standing to challenge tax credit } \\
\text { for schooling. Dissent (Kagan with all), break from precedent. }\end{array}$ & $\begin{array}{l}\text { E d u c a ti o n, } \\
\text { conservative }\end{array}$ \\
\hline $\begin{array}{l}\text { C u } 11 \text { e n v } \\
\text { Pinholster, } 131 \text { S. } \\
\text { Ct. } 1388 \text { (2011). }\end{array}$ & $\begin{array}{l}\text { Plurality: Death habeas, denied. Dissent } 1 \text { (Breyer), remand. } \\
\text { Dissent } 2 \text { (Sotomayor with Ginsburg \& Kagan), "[u]nder the } \\
\text { Court's novel interpretation of } \S 2254(\mathrm{~d})(1) \text {, however, federal } \\
\text { courts must turn a blind eye to new evidence in deciding } \\
\text { whether a petitioner has satisfied } \S 2254(\mathrm{~d})(1) \text { 's threshold } \\
\text { obstacle." }\end{array}$ & $\begin{array}{l}\text { C r i m P r o, } \\
\text { conservative }\end{array}$ \\
\hline $\begin{array}{l}\text { AT\&T Mobility } \\
\text { L L C V V . } \\
\text { Conception, } 131 \text { S. } \\
\text { Ct. } 1740 \text { (2011). }\end{array}$ & $\begin{array}{l}\text { Plurality: Promotion offering free phone where customers } \\
\text { were charged sales tax was subject to arbitration clause. } \\
\text { Dissent (Breyer with all), California contract law invalidating } \\
\text { arbitration contract for fraud should apply. }\end{array}$ & $\begin{array}{l}\text { B u s i n e s s, } \\
\text { conservative }\end{array}$ \\
\hline
\end{tabular}




\begin{tabular}{|c|c|c|}
\hline $\begin{array}{l}\text { Janus Capital } \\
\text { Group, Inc. v. First } \\
\text { Derivative Traders, } \\
131 \text { S. Ct. } 2296 \\
(2011) .\end{array}$ & $\begin{array}{l}\text { Parent fund company not liable for fund's misrepresentations. } \\
\text { Dissent (Breyer with all), parent should be liable. }\end{array}$ & $\begin{array}{l}\text { B u s i n e s s, } \\
\text { conservative }\end{array}$ \\
\hline $\begin{array}{l}\text { Wal-Mart Stores, } \\
\text { Inc. v. Dukes, } 131 \\
\text { S. Ct. } 2541 \text { (2011). }\end{array}$ & $\begin{array}{l}\text { Female Wal-Mart employee class action, defeated. Dissent } \\
\text { (Ginsburg with all), this class action has no commonality for } \\
\text { damages, but they may have commonality for other relief. }\end{array}$ & $\begin{array}{l}\text { B u s i n e s s, } \\
\text { conservative }\end{array}$ \\
\hline $\begin{array}{l}\text { Pliva, Inc. v. } \\
\text { Mensing, } 131 \mathrm{~S} . \\
\text { Ct. } 2567(2011)\end{array}$ & $\begin{array}{l}\text { Federal law preempts state drug labeling laws. Dissent } \\
\text { (Sotomayor with all), FDA permits drug makers to ask to } \\
\text { change their labels, removing preemption problem. }\end{array}$ & $\begin{array}{l}\text { B u s i n e s s, } \\
\text { conservative }\end{array}$ \\
\hline $\begin{array}{l}\text { Stern v. Marshall, } \\
131 \text { S. Ct. } 2594 \\
(2011) \text {. }\end{array}$ & $\begin{array}{l}\text { Bankruptcy: Debtor's counterclaim should have been heard } \\
\text { by Article III judge (Scalia concurrence). Dissent (Breyer } \\
\text { with all), core matters statute is constitutional. }\end{array}$ & $\begin{array}{l}\text { B u s i n e s s, } \\
\text { conservative }\end{array}$ \\
\hline $\begin{array}{l}\text { Ariz. Free Enter. } \\
\text { Club's Freedom } \\
\text { Club PAC v. } \\
\text { Bennett, } 131 \text { S. Ct. } \\
2806 \text { (2011). }\end{array}$ & $\begin{array}{l}\text { Arizona matching funds designed to equalize campaign } \\
\text { finance violate First Amendment. Dissent (Kagan with all), } \\
\text { "A person familiar with our country's core values... might } \\
\text { expect this Court to celebrate" the Arizona scheme. }\end{array}$ & $\begin{array}{l}\mathrm{S} p \mathrm{p} \text { e } \mathrm{c} \mathrm{h} \\
\text { conservative }\end{array}$ \\
\hline $\begin{array}{l}\text { Garcia v. Tex., } 131 \\
\text { S. Ct. } 2866 \text { (2011). }\end{array}$ & $\begin{array}{l}\text { Death habeas stay denied. Dissent (Breyer with all), unless } \\
\text { Court stays, U.S. breaches Vienna convention. }\end{array}$ & $\begin{array}{l}\mathrm{C} \text { r i m P r o, } \\
\text { conservative }\end{array}$ \\
\hline $\begin{array}{l}\text { Coleman v. Ct. of } \\
\text { Appeals of Md., } \\
132 \text { S. Ct. } 1327 \\
(2012) \text {. }\end{array}$ & $\begin{array}{l}\text { Plurality: Sovereign immunity bars suits against states for } \\
\text { self-care leave. Dissent (Ginsburg with all) would hold that } \\
\text { leave "validly enforces the right to be free from gender } \\
\text { discrimination in the workplace." }\end{array}$ & $\begin{array}{l}\text { S o c i a } 1 \text {, } \\
\text { conservative }\end{array}$ \\
\hline $\begin{array}{l}\text { Florence v. Bd. of } \\
\mathrm{C} \text { h o s e n } \\
\text { Freeholders of The } \\
\text { C o u n t y o f } \\
\text { Burlington, } 132 \mathrm{~S} . \\
\text { Ct. } 1510 \text { (2012). }\end{array}$ & $\begin{array}{l}\text { Plurality: Arrestee's searches did not violate Fourth and } \\
\text { Fourteenth amendments. Dissent (Breyer with all), for minor } \\
\text { offense is unreasonable. }\end{array}$ & $\begin{array}{l}\text { C r i m P r o } \\
\text { conservative }\end{array}$ \\
\hline $\begin{array}{l}\text { Christopher v. } \\
\text { S m it h K } 1 \text { i n e } \\
\text { Beecham Corp, } \\
132 \text { S. Ct. } 2156 \\
(2012) \text {. }\end{array}$ & $\begin{array}{l}\text { Drug salesmen are outside salesmen not subject to minimum } \\
\text { wage and max hours statutory limits. Dissent (Breyer with } \\
\text { all), they are not outside salesmen hence not exempt. }\end{array}$ & $\begin{array}{l}\text { B u s i n e s s, } \\
\text { conservative }\end{array}$ \\
\hline $\begin{array}{l}\text { Am. Tradition } \\
\text { P'ship, Inc. v. } \\
\text { Bullock, } 132 \text { S. Ct. } \\
2490 \text { (2012). }\end{array}$ & $\begin{array}{l}\text { Per curiam: Montana corporate campaign contribution statute } \\
\text { violates First Amendment. Dissent (Breyer with all) disagree } \\
\text { with Citizens United and Montana court made independent } \\
\text { finding of corrupting effect. }\end{array}$ & $\begin{array}{l}\mathrm{S} p \text { e e c h } \\
\text { conservative }\end{array}$ \\
\hline $\begin{array}{l}\text { Nat'l Fed'n of } \\
\text { Indep. Bus. v. } \\
\text { Sebelius, } 132 \text { S. Ct. } \\
2566 \text { (2012). }\end{array}$ & $\begin{array}{l}\text { Upholds Obamacare, not Medicaid expansion. Dissent } \\
\text { (Ginsburg with all), all valid. }\end{array}$ & $\begin{array}{l}\mathrm{H} \text { e a } 1 \mathrm{t} h \\
\text { conservative }\end{array}$ \\
\hline $\begin{array}{l}\text { C } 1 \text { a p p e r } \quad \mathrm{v} \text {. } \\
\text { Amnesty Int'l, } 133 \\
\text { S. Ct. } 1138 \text { (2013). }\end{array}$ & $\begin{array}{l}\text { Challenge to foreign surveillance, cannot trace injury, no } \\
\text { standing; dissent (Breyer with all), they should have standing. }\end{array}$ & $\begin{array}{l}\text { S o c i a } 1 \text {, } \\
\text { conservative }\end{array}$ \\
\hline
\end{tabular}




\begin{tabular}{|c|c|c|}
\hline $\begin{array}{l}\text { Comcast Corp. v. } \\
\text { Behrend, } 133 \text { S. Ct. } \\
1426(2013)\end{array}$ & $\begin{array}{l}\text { Denies certification of class action alleging monopolization } \\
\text { by cable company. Dissent (Ginsburg \& Breyer with all) } \\
\text { dismiss as improvidently granted because court did not } \\
\text { examine the details. }\end{array}$ & $\begin{array}{l}\text { B u s i n e s s, } \\
\text { conservative }\end{array}$ \\
\hline $\begin{array}{l}\text { Genesis Healthcare } \\
\text { Corp. v. Symczyk, } \\
133 \text { S. Ct. } 1523 \\
(2013) \text {. }\end{array}$ & $\begin{array}{l}\text { Employer's offer to make employee plaintiff whole } \\
\text { extinguished class action. Dissent (Kagan with all), makes no } \\
\text { sense, she never accepted and was not paid. }\end{array}$ & $\begin{array}{l}\text { B u s i n e s s, } \\
\text { conservative }\end{array}$ \\
\hline $\begin{array}{l}\text { Boyer v. La., } 133 \\
\text { S. Ct. } 1702 \text { (2013). }\end{array}$ & $\begin{array}{l}\text { Per curiam: Death; Writ dismissed as improvidently granted; } \\
\text { concurrence (Alito with Scalia \& Thomas), defense counsel } \\
\text { caused delay. Dissent (Sotomayor with all), seven-year delay } \\
\text { does not offend speedy trial, right? }\end{array}$ & $\begin{array}{l}\mathrm{C} \text { r i m P r o, } \\
\text { conservative }\end{array}$ \\
\hline $\begin{array}{l}\text { Salinas v. Tex., } 133 \\
\text { S. Ct. } 2174 \text { (2013). }\end{array}$ & $\begin{array}{l}\text { Plurality: Incriminating use of noncustodial silence } \\
\text { appropriate. Dissent (Breyer with all), "the Fifth Amendment } \\
\text { here prohibits the prosecution from commenting on the } \\
\text { petitioner's silence in response to police questioning." }\end{array}$ & $\begin{array}{l}\mathrm{C} \mathrm{r} \text { i m P r o, } \\
\text { conservative }\end{array}$ \\
\hline $\begin{array}{l}\text { Mut. Pharm. Co., } \\
\text { Inc. v. Bartlett, } 133 \\
\text { S. Ct. } 2466(2013) \text {. }\end{array}$ & $\begin{array}{l}\text { Claim against drug manufacturer defeated as labeling was } \\
\text { preemptedly constrainedly correct. Dissent } 1 \text { (Breyer with } \\
\text { Kagan), FDA has been clumsy but still could comply. Dissent } \\
2 \text { (Sotomayor with Ginsburg), "Today, the Court } \\
\text { unnecessarily and unwisely extends its holding in [Mensing] } \\
\text { to pre-empt New Hampshire's law governing design-defects } \\
\text { with respect to generic drugs." }\end{array}$ & $\begin{array}{l}\text { B u s i n e s s, } \\
\text { conservative }\end{array}$ \\
\hline $\begin{array}{l}\text { Vance v. Ball State } \\
\text { Univ., } 133 \text { S. Ct. } \\
2434 \text { (2013). }\end{array}$ & $\begin{array}{l}\text { Supervisors only those who can take tangible employment } \\
\text { actions against victim; harasser was not supervisor. Dissent } \\
\text { (Ginsburg with all), the court "disserves the objective of Title } \\
\text { VII to prevent discrimination." }\end{array}$ & $\begin{array}{l}\text { B u s i n e s s, } \\
\text { conservative }\end{array}$ \\
\hline $\begin{array}{l}\text { Univ. Of Tex. S.W. } \\
\text { Med. Ctr. v. } \\
\text { Nassar, } 133 \text { S. Ct. } \\
2517 \text { (2013). }\end{array}$ & $\begin{array}{l}\text { Title VII retaliation claims need but-for causation showing. } \\
\text { Dissent (Ginsburg with all), "Today's decision, however, } \\
\text { drives a wedge between the twin safeguards in so-called } \\
\text { 'mixed-motive' cases." }\end{array}$ & $\begin{array}{l}\text { B u s i n e s s, } \\
\text { conservative }\end{array}$ \\
\hline $\begin{array}{l}\text { Shelby County v. } \\
\text { Holder, } 133 \text { S. Ct. } \\
2612(2013) \text {. }\end{array}$ & $\begin{array}{l}\text { Voting rights act does not apply. Dissent (Ginsburg with all), } \\
\text { "The same assumption-that the problem could be solved } \\
\text { when particular methods of voting discrimination are } \\
\text { identified and eliminated—was indulged and proved wrong } \\
\text { repeatedly prior to the VRA's enactment. Unlike prior } \\
\text { statutes, which singled out particular tests or devices, the } \\
\text { VRA is grounded in Congress' recognition of the 'variety and } \\
\text { persistence' of measures designed to impair minority voting } \\
\text { rights." }\end{array}$ & $\begin{array}{l}\mathrm{S} p \text { e e c h, } \\
\text { conservative }\end{array}$ \\
\hline
\end{tabular}




\begin{tabular}{|c|c|c|}
\hline $\begin{array}{l}\text { Koontz v. St. Johns } \\
\text { River Water Mgmt. } \\
\text { Dist., } 133 \text { S. Ct. } \\
2586 \text { (2013). }\end{array}$ & $\begin{array}{l}\text { Condition of land use permit on funding offsite mitigation an } \\
\text { unconstitutional condition. Dissent (Kagan with all), "cases } \\
\text { in which the government conditions a permit not on the } \\
\text { transfer of real property, but instead on the payment or } \\
\text { expenditure of money. That runs roughshod over Eastern } \\
\text { Enterprises v. Apfel..., which held that the government may } \\
\text { impose ordinary financial obligations without triggering the } \\
\text { Takings Clause's protections. The boundaries of the } \\
\text { majority's new rule are uncertain. But it threatens to subject } \\
\text { a vast array of land-use regulations, applied daily in States } \\
\text { and localities throughout the country, to heightened } \\
\text { constitutional scrutiny." }\end{array}$ & $\begin{array}{l}\text { B u s i n e s s, } \\
\text { conservative }\end{array}$ \\
\hline $\begin{array}{l}\text { McCutcheon v. } \\
\text { FEC, } 134 \text { S. Ct. } \\
1434 \text { (2014). }\end{array}$ & $\begin{array}{l}\text { Statutory aggregate limits on how much money a donor may } \\
\text { contribute in total to all political candidates or committees } \\
\text { violates the First Amendment. Dissent (Breyer with all), } \\
\text { breaking from precedent. }\end{array}$ & $\begin{array}{l}\mathrm{S} p \text { e e c h, } \\
\text { conservative }\end{array}$ \\
\hline $\begin{array}{l}\text { Town Of Greece v. } \\
\text { Galloway, } 134 \text { S. } \\
\text { Ct. } 1811 \text { (2014). }\end{array}$ & $\begin{array}{l}\text { Prayer opening town meetings does not violate establishment } \\
\text { clause. Dissent } 1 \text { (Breyer), town did not call on all faiths; } \\
\text { Dissent } 2 \text { (Kagan with all), "I think the Town of Greece's } \\
\text { prayer practices violate that norm of religious equality-the } \\
\text { breathtakingly generous constitutional idea that our public } \\
\text { institutions belong no less to the Buddhist or Hindu than to } \\
\text { the Methodist or Episcopalian." }\end{array}$ & $\begin{array}{l}\mathrm{R} \text { e } 1 \text { i g i o } \mathrm{n}, \\
\text { conservative }\end{array}$ \\
\hline $\begin{array}{l}\text { Burwell v. Hobby } \\
\text { Lobby Stores, } 134 \\
\text { S. Ct. } 2751 \text { (2014). }\end{array}$ & $\begin{array}{l}\text { RFRA allows employers out from family planning of } \\
\text { Obamacare. Dissent (Ginsburg with all), "In a decision of } \\
\text { startling breadth, the Court holds that commercial enterprises, } \\
\text { including corporations, along with partnerships and sole } \\
\text { proprietorships, can opt out of any law (saving only tax laws) } \\
\text { they judge incompatible with their sincerely held religious } \\
\text { beliefs." Dissent } 2 \text { (Kagan and Breyer) join most of dissent. }\end{array}$ & $\begin{array}{l}\mathrm{R} \text { e } 1 \text { i g i o } \mathrm{n}, \\
\text { conservative }\end{array}$ \\
\hline $\begin{array}{l}\text { Harris v. Quinn, } \\
134 \text { S. Ct. } 2618 \\
(2014) .\end{array}$ & $\begin{array}{l}\text { Personal assistants who do not belong to Union do not need } \\
\text { to pay dues. Dissent (Kagan with all), "Abood held that a } \\
\text { government entity may, consistently with the First } \\
\text { Amendment, require public employees to pay a fair share of } \\
\text { the cost that a union incurs negotiating on their behalf for } \\
\text { better terms of employment." }\end{array}$ & $\begin{array}{l}\text { Employment, } \\
\text { conservative }\end{array}$ \\
\hline $\begin{array}{l}\text { Kerry v. Din, } 135 \\
\text { S. Ct. } 2128 \text { (2015). }\end{array}$ & $\begin{array}{l}\text { Plurality: "[A]assuming that citizen had a procedural due } \\
\text { process right to an explanation of the grounds for the denial } \\
\text { of husband's visa application, that right was satisfied when a } \\
\text { consular officer informed citizen that her husband was } \\
\text { inadmissible under Immigration and Nationality Act's (INA) } \\
\text { 'terrorist activities' bar." Dissent (Breyer with all), "She } \\
\text { possesses the kind of 'liberty' interest to which the Due } \\
\text { Process Clause grants procedural protection." }\end{array}$ & $\begin{array}{l}\text { A } \mathrm{d} \mathrm{m} \mathrm{i} \mathrm{n} \text {, } \\
\text { conservative }\end{array}$ \\
\hline $\begin{array}{l}\text { Davis v. Ayala, } \\
135 \text { S. Ct. } 2187 \\
(2015) .\end{array}$ & $\begin{array}{l}\text { Death habeas: Plurality: "any constitutional error in defense } \\
\text { counsel's absence from ex parte hearing regarding Batson } \\
\text { challenges was harmless." Dissent (Sotomayor with all), } \\
\text { "there is neither a factual nor a legal basis for the Court's } \\
\text { confidence that the prosecution's race-neutral reasons for } \\
\text { striking Olanders D. were unassailable." }\end{array}$ & $\begin{array}{l}\mathrm{C} \text { r i m P r o, } \\
\text { conservative }\end{array}$ \\
\hline
\end{tabular}




\begin{tabular}{|l|l|l|l|}
\hline Mich. v. EPA, 135 & $\begin{array}{l}\text { EPA must take cost into account when regulating. Dissent } \\
\text { (Kagan with all), "The Environmental Protection Agency } \\
\text { placed emissions limits on coal and oil power plants } \\
\text { following a lengthy regulatory process during which the } \\
\text { Agency carefully considered costs." }\end{array}$ & $\begin{array}{l}\text { A } \\
\text { conservative }\end{array}$ \\
\hline $\begin{array}{l}\text { Glossip v. Gross, } \\
\text { 135 S. Ct. 2726 } 2015) .\end{array}$ & $\begin{array}{l}\text { Challenge to three-drug execution regime defeated. Dissent } \\
1 \text { (Breyer with Ginsburg) asks briefing on whether death } \\
\text { penalty violates constitution. Dissent 2 (Sotomayor with all), } \\
\text { "The latter two drugs are intended to paralyze the inmate and } \\
\text { stop his heart. But they do so in a torturous manner, causing } \\
\text { burning, searing pain. It is thus critical that the first drug, } \\
\text { midazolam, do what it is supposed to do, which is to render } \\
\text { and keep the inmate unconscious. Petitioners claim that } \\
\text { midazolam cannot be expected to perform that function, and } \\
\text { they have presented ample evidence showing that the State's } \\
\text { planned use of this drug poses substantial, constitutionally } \\
\text { intolerable risks." }\end{array}$ & | \\
\hline
\end{tabular}

\section{ROBERTS-ALITO-BREYER-KENNEDY-THOMAS (FOUR O'CLOCK)}

\begin{tabular}{|c|c|c|}
\hline $\begin{array}{l}\text { Williams v. Ill., } \\
132 \text { S. Ct. } 2221 \\
(2012) .\end{array}$ & $\begin{array}{l}\text { DNA expert testimony admissible without confrontation. } \\
\text { Dissent (Kagan with all), need confrontation to avoid errors } \\
\text { (with examples). }\end{array}$ & $\begin{array}{l}\mathrm{C} \mathrm{r} \text { i m P r o, } \\
\text { conservative }\end{array}$ \\
\hline $\begin{array}{l}\text { Md. v. King, } 133 \text { S. } \\
\text { Ct. } 1958 \text { (2013). }\end{array}$ & $\begin{array}{l}\text { Buccal swab DNA evidence admissible. Dissent (Scalia with } \\
\text { all), "The Court's assertion that DNA is being taken, not to } \\
\text { solve crimes, but to identify those in the State's custody, taxes } \\
\text { the credulity of the credulous." }\end{array}$ & $\begin{array}{l}\mathrm{C} \mathrm{r} \text { i m P r o, } \\
\text { conservative }\end{array}$ \\
\hline $\begin{array}{l}\text { Maracich v. Spears, } \\
133 \text { S. Ct. } 2191 \\
(2013) .\end{array}$ & $\begin{array}{l}\text { Lawyers sending letters to DMV lists violates DPPA. Dissent } \\
\text { (Ginsburg with all), "the lawyers' requests for the information } \\
\text { and their use of it fell squarely within the litigation exception } \\
\text { to the Driver's Privacy Protection Act of 1994." }\end{array}$ & $\begin{array}{l}\text { B u s i n e s s, } \\
\text { conservative }\end{array}$ \\
\hline $\begin{array}{l}\text { Adoptive Couple v. } \\
\text { Baby Girl, } 133 \mathrm{~S} \text {. } \\
\text { Ct. } 2552 \text { (2013). }\end{array}$ & $\begin{array}{l}\text { Indian Child Welfare Act does not enable parent who never } \\
\text { had custody from blocking adoption. Dissent } 1 \text { (Scalia), court } \\
\text { demeans rights of parenthood. Dissent } 2 \text { (Sotomayor with } \\
\text { all), "the Congress that enacted the statute announced its } \\
\text { intent to stop 'an alarmingly high percentage of Indian } \\
\text { families [from being] broken up' by, among other things, a } \\
\text { trend of 'plac[ing] [Indian children] in non-Indian . . } \\
\text { adoptive homes."' }\end{array}$ & $\begin{array}{l}\mathrm{S} \text { o c i a } 1, \\
\text { conservative }\end{array}$ \\
\hline $\begin{array}{l}\text { Navarette v. Cal., } \\
134 \text { S. Ct. } 1683 \\
(2014) .\end{array}$ & $\begin{array}{l}911 \text { call gave sufficient grounds for stop and search of truck, } \\
\text { evidence not suppressed. Dissent (Scalia with all), precedent } \\
\text { is that anonymous tips need corroboration. }\end{array}$ & $\begin{array}{l}\mathrm{C} \mathrm{r} \text { i m P r o, } \\
\text { conservative }\end{array}$ \\
\hline
\end{tabular}

